Evaluation of Juvenile Salmon Outmigration and Survival in the Lower Umatilla River Basin

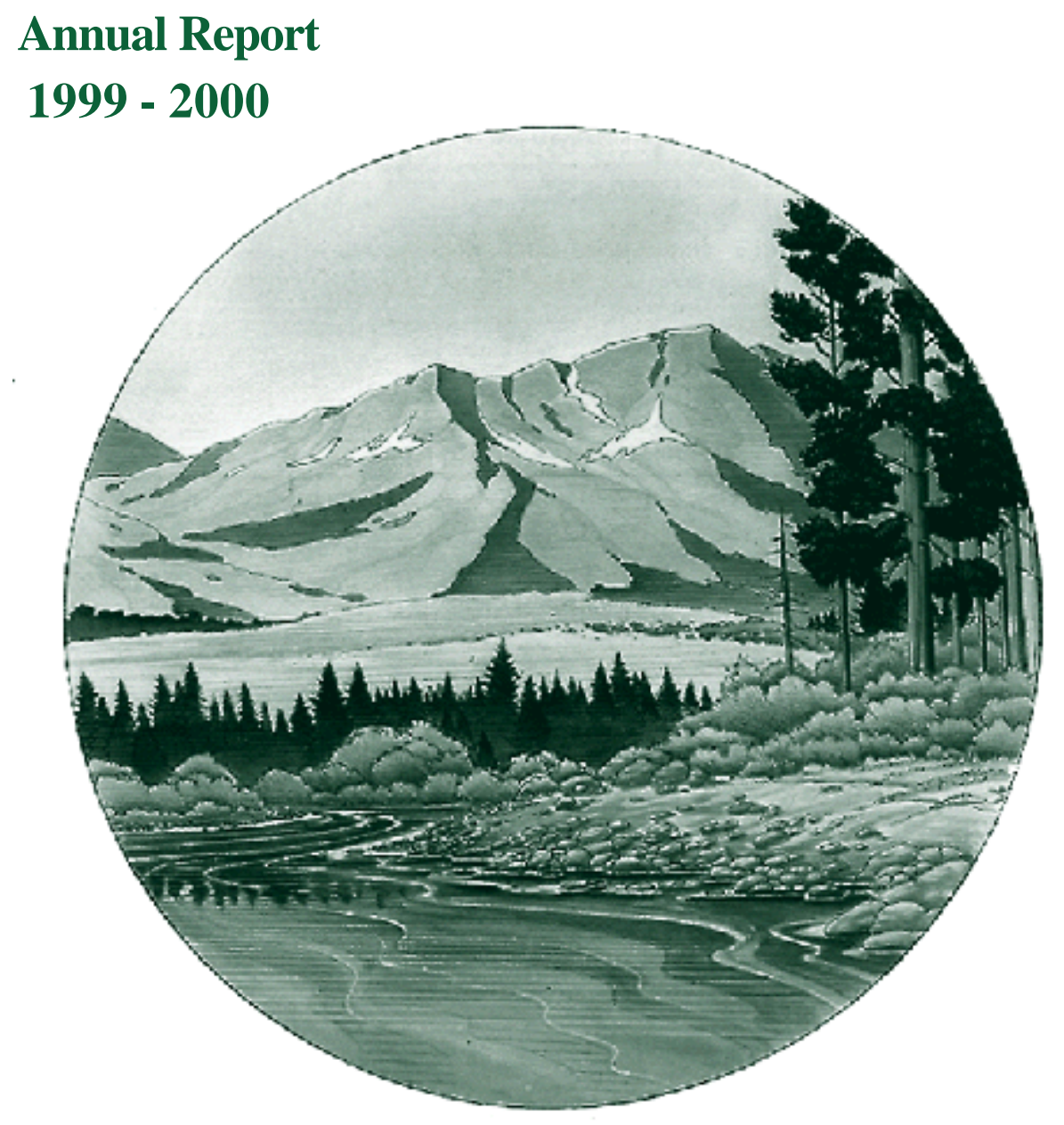

DOE/BP-00004340-2

April 2002 
This Document should be cited as follows:

Knapp, Suzanne, Richard Carmichael, Danette Ehlers, Shannon Jewett, "Evaluation of

Juvenile Salmon Outmigration and Survival in the Lower Umatilla River Basin", Project

No. 1989-02401, 151 electronic pages, (BPA Report DOE/BP-00004340-2)

Bonneville Power Administration

P.O. Box 3621

Portland, Oregon 97208

This report was funded by the Bonneville Power Administration (BPA), U.S. Department of Energy, as part of BPA's program to protect, mitigate, and enhance fish and wildlife affected by the development and operation of hydroelectric facilities on the Columbia River and its tributaries. The views in this report are the author's and do not necessarily represent the views of BPA. 


\title{
EVALUATION OF JUVENILE SALMONID OUTMIGRATION AND SURVIVAL IN THE LOWER UMATILLA RIVER BASIN
}

\author{
ANNUAL REPORT 2000 \\ (1 OCTOBER 1999 - 30 SEPTEMBER 2000) \\ Prepared by: \\ Suzanne M. Knapp \\ Danette L. Ehlers \\ Shannon M. Jewett \\ Richard W. Carmichael
Oregon Department of Fish and Wildlife
2501 S.W. First Avenue
P.O. Box 59
Portland, OR 97207

Prepared for:

\author{
U.S. Department of Energy \\ Bonneville Power Administration \\ Environment, Fish and Wildlife \\ P.O. Box 3621 \\ Portland, OR 97208-3621 \\ Project Number 1989-024-01 \\ Contract Number 00000152-00001
}

April 2002 
This report was funded by the Bonneville Power Administration (BPA), U.S. Department of Energy, as part of BPA's program to protect, mitigate, and enhance fish and wildlife affected by the development and operation of hydroelectric facilities on the Columbia River and its tributaries. The views of this report are the author's and do not necessarily represent the views of BPA.

This document should be cited as follows:

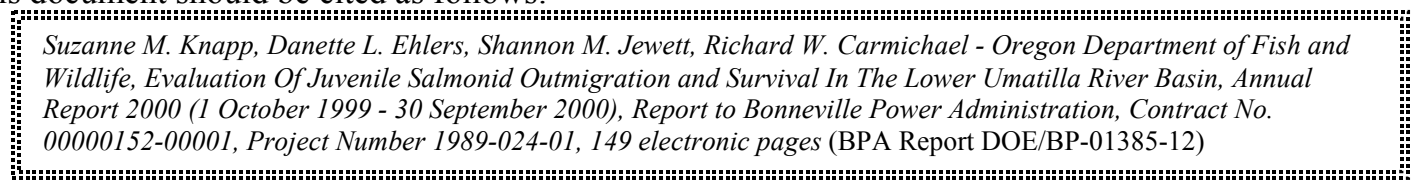

This report and other BPA Fish and Wildlife Publications are available on the Internet at:

http://www.efw.bpa.gov/cgi-bin/efw/FW/publications.cgi

For other information on electronic documents or other printed media, contact or write to:

Bonneville Power Administration

Environment, Fish and Wildlife Division

P.O. Box 3621

905 N.E. 11 th Avenue

Portland, OR 97208-3621

Please include title, author, and DOE/BP number in the request. 


\section{TABLE OF CONTENTS}

EXECUTIVE SUMMARY

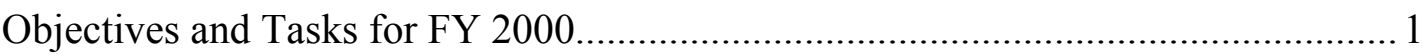

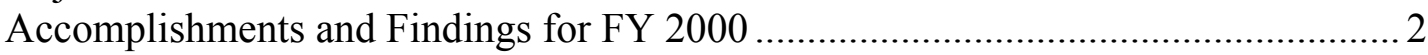

Management Implications and Recommendations ……….......................................... 6

INTRODUCTION

STUDY SITES

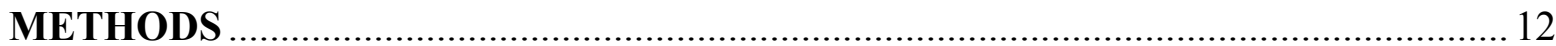

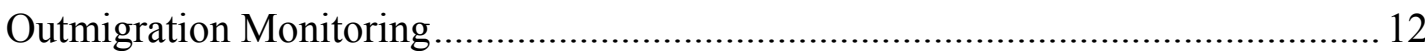

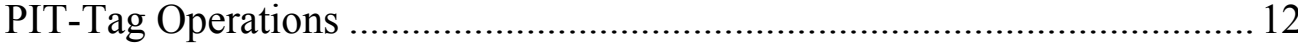

Trap Efficiencies ................................................................................. 14

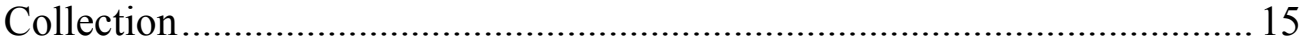

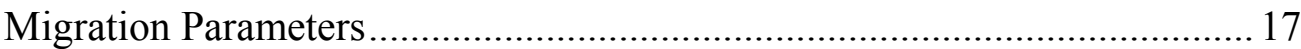

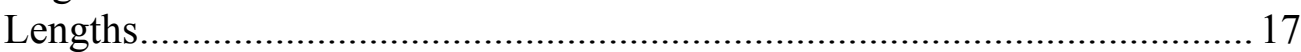

Fish Condition and Health ....................................................................... 17

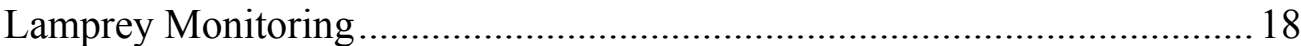

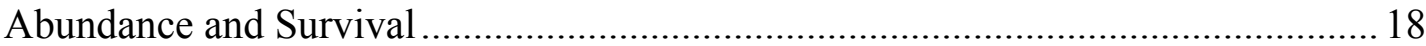

Migrant Abundance and Survival ............................................................... 18

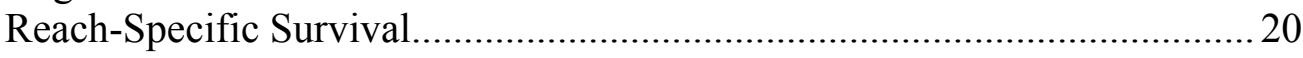

Environmental Conditions and Bypass Operations ……………………………..... 21

Resident Fish and Predators..............................................................................22

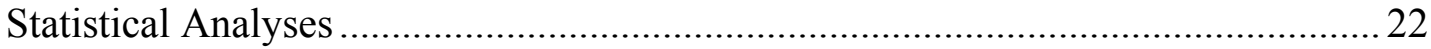

RESULTS ....

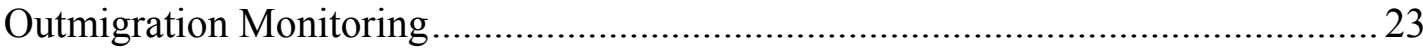

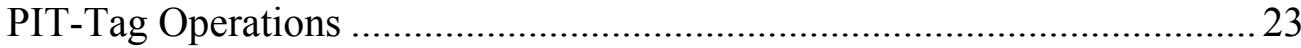

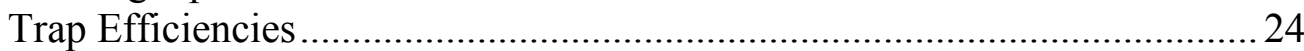

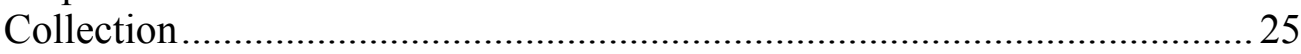

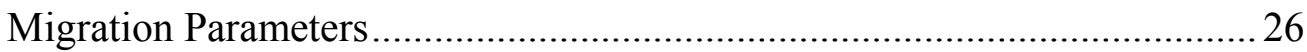

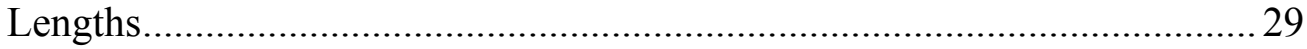

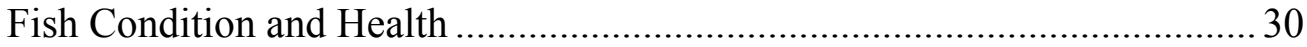

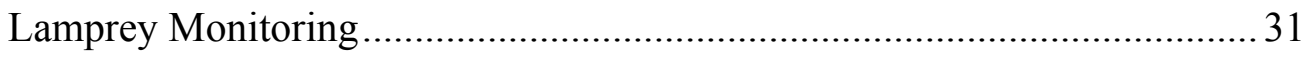

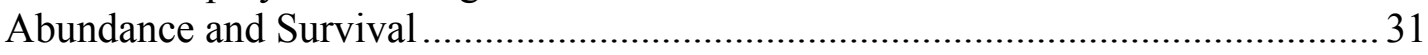

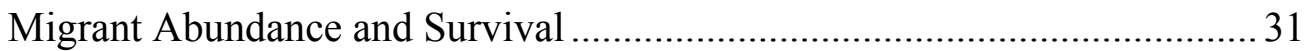

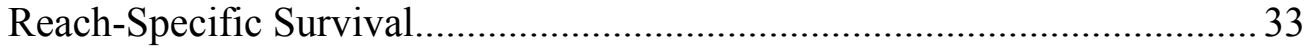

Environmental Conditions and Bypass Operations …………..................................... 34

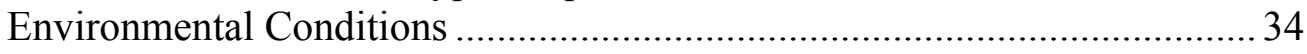

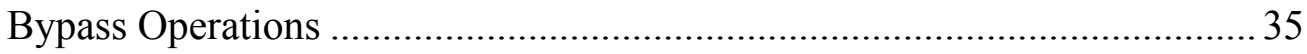


Resident Fish and Predators

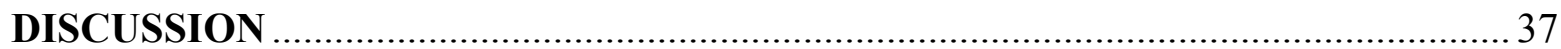

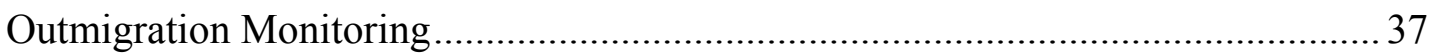

Abundance and Survival .................................................................................... 40

Environmental Conditions and Bypass Operations ..................................................4 43

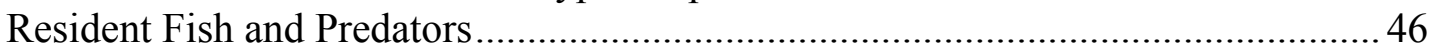

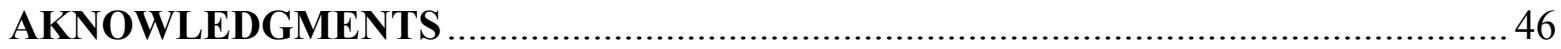

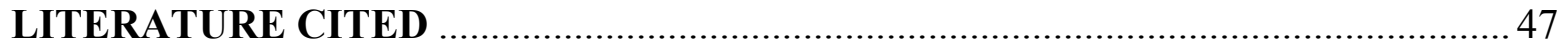

\section{LIST OF TABLES}

Table 1. Type and number of PIT-tag files created during monitoring activities at

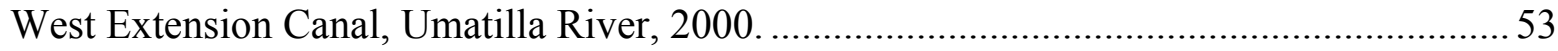

Table 2. PIT-tagged fish from different hatcheries and hatchery rearing strategies detected at West Extension Canal, RM 3.7, Umatilla River, March - September 2000 ........53

Table 3. Natural fish PIT tagged by CTUIR, released at upper Umatilla River sites, and detected at West Extension Canal (RM 3.7), Umatilla River, March - September 2000 .

Table 4. PIT-tag recoveries at mainstem Columbia River islands from hatchery juvenile salmonids released for reach-specific survival tests in the Umatilla River, 2000. Islands are sites for bird colonies.

Table 5. Holding survival and tag retention of PIT-tagged hatchery and natural juvenile salmonids used in trap efficiency tests at West Extension Canal (RM 3.7), Umatilla River, March - July 2000.

Table 6. Trap efficiency releases and detections of hatchery and natural juvenile salmonids, mean travel times and trap efficiency estimates, West Extension Canal (RM 3.7), March - July 2000.

Table 7. Actual and adjusted collection of hatchery and natural juvenile salmonids at RM 1.2 and RM 3.7, Umatilla River, October 1999 - September 2000. 62

Table 8. Scale samples from hatchery and natural salmonids collected at RM 1.2 and RM 3.7 on the Umatilla River, March - September 2000. 
Table 9. Migration parameters of PIT-tagged hatchery, reach survival test, and natural juvenile salmonids detected at West Extension Canal (RM 3.7), Umatilla River, March - September 2000

Table 10. Summary of injuries, parasites, and diseases on hatchery and natural juvenile salmonids collected at RM 1.2 and RM 3.7, Umatilla River, March - July 2000. 68

Table 11. Summary of scale loss and mortality of hatchery and natural juvenile salmonids collected at RM 1.2 and RM 3.7, Umatilla River, March - July 2000.

Table 12. Release and recapture of juvenile Pacific lampreys (macrophthalmia) and trap efficiency estimates at the rotary-screw trap (RM 1.2), Umatilla River, November 1999 - February 2000

Table 13. Detection, abundance, and survival of PIT-tagged production fish released into the upper Umatilla River and detected in the lower river, March - June 2000.

Table 14. Detection, abundance, and survival of PIT-tagged natural fish released into the upper Umatilla River and tributaries and detected in the lower river, March June 2000

Table 15. Monthly abundance estimates of natural fish sampled in the lower Umatilla River, 2000.

Table 16. Mean length, tag loss, and holding mortality for tagged fish used in reachspecific survival tests, and tag consumption by fish during holding, Umatilla River, March - July 2000.

Table 17. Detection, abundance, and survival of PIT-tagged fish released for reachspecific survival tests and interrogated in the lower Umatilla River (RM 3.7), March - July 2000. Means with the same letter are not significantly different.

Table 18. Percent detection of PIT-tagged fish released for reach-specific survival tests and detected at Columbia River interrogation sites and all sites, March - July 2000. Means with the same letter are not significantly different. Duplicate detections are omitted.

Table 19. Correlations of daily detections with mean river flow $\left(\mathrm{ft}^{3} / \mathrm{s}\right)$ at $\mathrm{RM} 37.6$, temperature $\left({ }^{\circ} \mathrm{F}\right)$ at RM 37.6, and Secchi depth (m) at RM 3.7, lower Umatilla River, March - June 2000. * indicates significance $(P<0.05)$ 
Table 20. Percent detection of natural coho salmon and summer steelhead within discrete environmental parameters. Percent values in parentheses correspond to the proportion of time the parameter was represented within each species' detection period, Umatilla River, 2000. * indicates significance $(\mathrm{P}<0.05)$....

Table 21. Correlations between travel speed ( $\mathrm{mi} / \mathrm{d})$ and river flow $\left(\mathrm{ft}^{3} / \mathrm{s}\right)$ within the travel corridor and travel speed $(\mathrm{mi} / \mathrm{d})$ and delta flow $\left(\mathrm{ft}^{3} / \mathrm{s}\right)$ within the travel corridor based on daily detections of hatchery fish released for reach-specific survival tests, Umatilla River, 2000. The $\mathrm{r}$-value is presented with the $\mathrm{N}$-value in parentheses. * indicates significance $(\mathrm{P}<0.05)$.

Table 22. Correlations by species between diversion rate and trap efficiency estimates at West Extension Canal (RM 3.7), Umatilla River, March - July 2000.

$*$ indicates significance. $(P<0.05)$.

Table 23. Number and length range $(\mathrm{mm})$ of resident fish species captured at the rotary-screw trap (RM 1.2) and West Extension Canal (RM 3.7), lower Umatilla River, October 1999 - October 3, 2000.

Table 24. Avian predators observed during sampling at the rotary-screw trap (RM 1.2) and West Extension Canal (RM 3.7), Umatilla River, October 1999 - September 2000 .

\section{LIST OF FIGURES}

Figure 1. Study and activity sites on the Umatilla River, October 1999 - September 2000 .

Figure 2. Schematic of the rotary-screw trap with anchoring system and the West Extension Canal screening/bypass facility, lower Umatilla River, 2000.

Figure 3. Remote PIT-tag interrogation system $(134 \mathrm{kHz})$ used at West Extension Canal (RM 3.7) in 2000. 86

Figure 4. Process used to differentiate species, race, and origin of juvenile migrant fish in the Umatilla River, 2000.

Figure 5. Digitizer board setup used to record biological data in the field, 2000. 88

Figure 6. Weekly composition of hatchery, natural, and unknown juvenile salmonids sampled at West Extension Canal (RM 3.7), lower Umatilla River, March September 2000. 89 
Figure 7. Percent and cumulative percent detection at West Extension Canal (RM 3.7) of March and April releases of PIT-tagged hatchery yearling spring chinook salmon, Umatilla River, March - May 2000. The fiftieth percentile is marked with arrows and volitional release dates are indicated. LWS $=$ Little White Salmon Hatchery, UFH = Umatilla Fish Hatchery, $\mathrm{CFH}=$ Carson Fish Hatchery

Figure 8. Percent and cumulative percent detection of PIT-tagged hatchery yearling and subyearling fall chinook salmon at West Extension Canal (RM 3.7), Umatilla River, March - June 2000. Fiftieth percentile marked with arrows. Release dates are volitional for yearling fall chinook and forced for subyearling fall chinook salmon.

Figure 9. Percent and cumulative percent detection of PIT-tagged hatchery summer steelhead at West Extension Canal (RM 3.7), Umatilla River, April - June 2000. Fiftieth percentile marked with arrows and volitional release dates are indicated.

Figure 10. Percent and cumulative percent detection of PIT-tagged natural coho salmon and summer steelhead at West Extension Canal (RM 3.7), Umatilla River, April - June 2000. Sites indicated are where fish were released after being tagged

Figure 11. Diel detection of PIT-tagged hatchery yearling spring and fall chinook salmon and subyearling fall chinook salmon at West Extension Canal (RM 3.7), Umatilla River, March - June 2000.

Figure 12. Diel detection of PIT-tagged hatchery and natural summer steelhead and natural coho salmon at West Extension Canal (RM 3.7), Umatilla River, April - June 2000 .

Figure 13. Length-frequency distribution of hatchery yearling spring and fall chinook salmon and chinook salmon of unknown race captured in the lower Umatilla River, March - May 2000

Figure 14. Length-frequency distribution of hatchery subyearling fall chinook salmon, marked (AD-clipped) coho salmon, and hatchery summer steelhead captured in the lower Umatilla River, March - July 2000

Figure 15. Length-frequency distribution of natural chinook salmon, natural summer steelhead, and unmarked coho salmon captured in the lower Umatilla River, March September 2000 .

Figure 16. Length-frequency distribution of juvenile Pacific lamprey captured at the rotary-screw trap (RM 1.2), Umatilla River, October 1999 - March 2000. 
Figure 17. River flow $\left(\mathrm{ft}^{3} / \mathrm{s}\right)$ recorded at the UMAO gauging station (RM 2.1) and number of juvenile Pacific lamprey captured at the rotary-screw trap (RM 1.2), Umatilla River, October 1999 - March 2000

Figure 18. Mean daily river flows $\left(\mathrm{ft}^{3} / \mathrm{s}\right)$ recorded at four gauging stations on the Umatilla River, October 1999 - September 2000. Numbers shown are the monthly means at the UMAO gauging station (RM 2.1).

Figure 19. Mean Secchi depth (m) at RM 1.2 or 3.7 plotted against daily river flow $\left(\mathrm{ft}^{3} / \mathrm{s}\right)$ at RM 2.1, Umatilla River, October 1999 - September 2000.

Figure 20. Minimum and maximum water temperature $\left({ }^{\circ} \mathrm{F}\right)$ plotted against river flow $\left(\mathrm{ft}^{3} / \mathrm{s}\right)$ at RM 2.1, Umatilla River, October 1999 - September 2000

Figure 21. Daily river flow $\left(\mathrm{ft}^{3} / \mathrm{s}\right)$ at $\mathrm{RM} 3.7$ and 37.6 , daily mean temperature $\left({ }^{\circ} \mathrm{F}\right)$ at RM 3.7, and percent detection of natural coho salmon (NCOH) and summer steelhead (NSTS) at West Extension Canal (RM 3.7), Umatilla River, April - June 2000 .

Figure 22. Daily river flow $\left(\mathrm{ft}^{3} / \mathrm{s}\right)$ at $\mathrm{RM} 3.7$ and 37.6 , daily mean temperature $\left({ }^{\circ} \mathrm{F}\right)$ at RM 3.7, and percent detection of hatchery spring chinook salmon (HCHS) at West Extension Canal (RM 3.7), Umatilla River, March - May 2000.

Figure 23. Daily river flow $\left(\mathrm{ft}^{3} / \mathrm{s}\right)$ at $\mathrm{RM} 3.7$ and 37.6 , daily mean temperature $\left({ }^{\circ} \mathrm{F}\right)$ at RM 3.7, and percent detection of hatchery fall (HCHF), and subyearling fall (HCHF0) chinook salmon at West Extension Canal (RM 3.7), Umatilla River, March - June 2000.

Figure 24. Daily river flow $\left(\mathrm{ft}^{3} / \mathrm{s}\right)$ at $\mathrm{RM} 3.7$ and 37.6 , daily mean temperature $\left({ }^{\circ} \mathrm{F}\right)$ at RM 3.7, and percent detection of large- and small-grade hatchery summer steelhead (HSTS) at West Extension Canal (RM 3.7), Umatilla River, April - June 2000 .

Figure 25. Mean daily flows $\left(\mathrm{ft}^{3} / \mathrm{s}\right)$ for river discharge at UMAO gauging station (RM 2.1), Phase I exchange pumping, McKay Reservoir water releases, and canal diversion at West Extension Canal (RM 3.7) plotted with total percent detection of hatchery fish, Umatilla River, March - September 2000.

Figure 26. Percent of gulls observed and percent detection of juvenile salmonids at the canal trap (RM 3.7) plotted against river flow $\left(\mathrm{ft}^{3} / \mathrm{s}\right)$, Umatilla River, January July 2000. Number of gulls observed per day was standardized by the number of observations per day. 


\section{LIST OF APPENDIX TABLES}

Appendix Table A-1. Detection efficiency of the remote interrogation system at West Extension Canal (RM 3.7), Umatilla River, March - June 2000.

Appendix Table A-2. Detection and travel time by replicate group of PIT-tagged fish released for reach-specific survival tests and interrogated in the lower Umatilla River and at Columbia River interrogation and recovery sites, March - July 2000. Duplicate detections were removed from the count but not from travel time analysis

Appendix Table A-3. Maximum, minimum, and mean fork lengths (mm) of natural and hatchery juvenile salmonids, lower Umatilla River, November 1999 - September 2000 .

Appendix Table A-4. Pacific lamprey captures, trap efficiency estimates, and abundance estimates at the rotary-screw trap (RM 1.2) and West Extension Canal (RM 3.7), Umatilla River, October 1994 - June 2000.

Appendix Table A-5. Daily observations at the rotary-screw trap (RM 1.2), lower Umatilla River, 1 October 1999 - 5 March 2000.

Appendix Table A-6. Daily observations at the West Extension Canal sampling facility (RM 3.7), 7 March - 29 September 2000.

Appendix Table A-7. Estimates of survival and/or abundance for hatchery and natural juvenile salmonids migrating from the Umatilla River basin, 1995 - 2000.

Appendix Table A-8. Detection, abundance, and survival of PIT-tagged production fish released into the upper Umatilla River and detected in the lower river, December 1998 - July 1999. Abundance estimates recalculated based on methods used in 2000 .

Appendix Table A-9. Number and mean percent detection of PIT-tagged fish released for reach-specific survival and transport evaluation tests and interrogated in the lower Umatilla River (RM 3.7) and on the mainstem lower Columbia River, 1998 -2000 .

Appendix Table A-10. Releases of hatchery chinook salmon, coho salmon, and summer steelhead in the Umatilla River, November 1999 - May 2000 


\section{LIST OF APPENDIX FIGURES}

Page

Appendix Figure A-1. Migration duration and frequency of juvenile Pacific lamprey

(macrophthalmia), lower Umatilla River, November 1998 - March $2000 .$.

Appendix Figure A-2. River flow $\left(\mathrm{ft}^{3} / \mathrm{s}\right)$ measured at RM 2.1, lower Umatilla River,

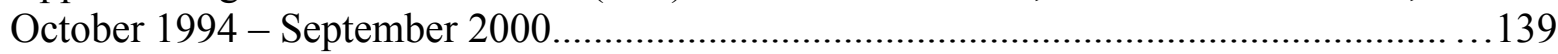




\section{EXECUTIVE SUMMARY}

This is the sixth annual report of a multi-year project that monitors the outmigration and survival of hatchery and natural juvenile salmonids in the lower Umatilla River. This project supplements and complements ongoing or completed fisheries projects in the Umatilla River basin. Knowledge gained on outmigration and survival assists researchers and managers in adapting hatchery practices, flow enhancement strategies, canal and fish ladder operations, and supplementation and enhancement efforts for natural and restored fish populations. Findings from this study also measure the success of upriver habitat improvement projects and provide an overall evaluation of the Umatilla River fisheries restoration program.

\section{Objectives and Tasks for FY 2000}

Objective 1. Use PIT-tag technology to monitor tagged hatchery and natural juvenile salmonids emigrating from the Umatilla basin.

Task 1.1 Install a $134 \mathrm{kHz}$ remote PIT-tag detection system at West Extension Canal. Task 1.2 Initiate PIT-tagging and monitoring activities.

Task 1.3 Edit, send, and retrieve PIT-tag files.

Objective 2. Determine migration performance and pattern, migrant abundance, and survival of PIT-tagged hatchery and natural juvenile salmonids in the lower Umatilla River.

Task 2.1 Determine trap collection efficiencies.

Task 2.2 Determine migration performance and pattern and migrant abundance of PITtagged hatchery spring and fall chinook salmon and summer steelhead in the lower Umatilla River.

Task 2.3 Determine migration performance and pattern, life history characteristics, and migrant abundance of tagged natural spring chinook salmon and summer steelhead and untagged fall chinook salmon within the lower Umatilla River.

Task 2.4 Estimate survival of PIT-tagged hatchery spring and fall chinook salmon and summer steelhead in the lower Umatilla River.

Task 2.5 Estimate reach-specific survival of PIT-tagged hatchery fish.

Task 2.6 Estimate survival of tagged naturally-produced juvenile salmonids in the lower Umatilla River.

Objective 3. Investigate effects of river and canal flow, water temperature, and other environmental variables on fish migration.

Task 3.1 Measure and obtain environmental and canal operations data.

Task 3.2 Correlate environmental variables with fish migration parameters.

Objective 4. Monitor the movement of juvenile Pacific lamprey in the lower Umatilla River and estimate trapping efficiency. 
Task 4.1 Monitor the migration of juvenile lamprey.

Task 4.2 Conduct trap efficiency tests with juvenile lamprey.

Objective 5. Participate in Planning and Coordination Activities in the Basin.

\section{Accomplishments and Findings for FY 2000}

We achieved all objectives in FY 2000. In addition to the required tasks, we observed and noted the presence of resident fish in our samples and avian predators near trap sites.

We monitored juvenile migrants at two locations in the lower river (RMs 1.2 and 3.7) throughout the entire contract period from 1 October 1999 through 30 September 2000. We did not sample at Westland Canal (RM 27.3) during juvenile fish transport operations as in past years.

\section{PIT-Tag Operations}

Remote interrogation at West Extension Canal was upgraded to a $134 \mathrm{kHz}$ system, using a Minimon program to process interrogated codes. Efficiency of the remote detection system was $>100 \%$ due to duplicate readings. Monitoring of PIT-tagged fish was continuous; $>98 \%$ of detected fish were detected remotely.

March-released fall chinook salmon (Bonneville Hatchery) were detected more than similarly released spring chinook salmon (Umatilla and Little White Salmon hatcheries), although all detections were $\leq 10$. Of April releases, detections of spring chinook salmon from Carson Hatchery and fall chinook salmon (Bonneville) were similar and greater than spring chinook salmon from Little White Salmon Hatchery. In May, groups of subyearling fall chinook salmon reared at different densities were detected similarly. In April, steelhead release groups were detected variably; greatest detection was for large-grade steelhead released at Minthorn. Most detections of natural summer steelhead and coho salmon were from fish tagged in the mainstem Umatilla River and Squaw Creek. Only one tagged natural spring chinook salmon was detected.

PIT-tag recoveries from island bird colonies in the Columbia River were higher for summer steelhead than spring or subyearling fall chinook salmon. Most mortalities were attributed to the East Sand Island rookery (RM 5).

\section{Trap Efficiencies}

At West Extension Canal, mean of sub-pooled trap efficiency estimates ranged between 17.6 $-32.9 \%$ for hatchery fish and $25.8-32.6 \%$ for natural fish. Most fish were detected within the first day or two after release; most subyearling chinook salmon were detected on the day of release. Survival and tag retention after tagging was high, except when temperatures neared 20 ${ }^{\circ} \mathrm{C}$. Travel speed for released test fish increased as the season progressed. 


\section{Collection}

Adjusted collection at the rotary-screw trap from 1 October through 6 March (199 fish) consisted mostly of hatchery summer steelhead grade-outs (pre-smolt releases). Capture of natural salmonids began in late December (spring chinook salmon) and late November (summer steelhead).

Sampling at West Extension Canal was conducted from 6 March through end of September. Collection totaled 15,573 hatchery salmonids, 15,027 coho salmon of unknown origin, and 4,200 natural fish, mostly chinook salmon. Capture timing over the season was similar for hatchery and natural conspecifics. Mini-jack chinook salmon entered the samples in July and September and natural chinook salmon continued to be caught late in the season. Mostly subyearling life stages of natural chinook and unmarked coho salmon were collected in June and July.

\section{Migration Parameters}

Most tagged yearling spring and fall chinook salmon were detected a few days after release from acclimation sites. April-released fish peaked in detection in late April; there were no detection peaks for March-released fish. For both spring and fall chinook salmon, detection duration and travel speed was shorter and faster for April-released fish than March-released fish. Peak detection of subyearling fall chinook salmon was soon after release and duration was short. Subyearling travel speed was 10 times the travel speed of yearling fish. An experimental group of larger-sized subyearlings (non-acclimated) exhibited similar migration characteristics as standard production releases.

Detection of large-grade steelhead released at Bonifer and Minthorn peaked $45 \mathrm{~d}$ after forced release, with Minthorn-released steelhead peaking earlier. Later-released small-grade steelhead traveled faster; peak detection coincided with large-grade steelhead. Small-grade steelhead experimentally released with steelhead larges had similar travel speeds and peak detection date (early June), although first and last detections for Bonifer-released fish were delayed.

Travel speed of spring chinook salmon and subyearling fall chinook salmon released in reach-survival tests progressively increased with distance upstream, although first detection was later and detection duration longer for upper-river released fish. Travel time to John Day Dam was the same for all subyearling release groups, including the group released at RM 0 , whereas travel time increased by 1 day for spring chinook salmon released at RM 80. First and last detections of summer steelhead ranged respectively from 1 day and 1 month (lower reaches) to 2 weeks and 6 weeks (upper sites) after release. Travel speed and travel time was fastest and shortest for lower-river released fish.

Natural yearling coho salmon tagged mostly in December, April, and May and natural steelhead tagged mostly in April and May were detected mostly in May; both completed their

migration by early June. Travel speeds for both species were fastest for fish tagged in the Umatilla River versus tributary sites. 
With few exceptions, most tagged fish passed the detection site between sunrise and sunset with peak movement at various times of the day. Generally, yearling chinook salmon were detected during mid-day and subyearling chinook salmon throughout the day. Hatchery and natural summer steelhead also moved throughout the day with slight shifts with succeeding months.

\section{Lengths}

Larger hatchery spring chinook, subyearling fall chinook, and coho salmon were more evident later in the season, whereas larger yearling fall chinook salmon were more apparent in March. Smaller-sized hatchery steelhead were collected in mid-May. Fry-sized natural chinook salmon were collected from March to June; lengths increased for subyearling natural chinook salmon between June/July (65 - $95 \mathrm{~mm}$ FL) and August/September (120 mm modal FL). Steelhead lengths varied considerably among months. In June, unmarked coho salmon were primarily between $65-80 \mathrm{~mm}$ FL.

\section{Fish Condition and Health}

Bird marks represented $50-68 \%$ of the injuries incurred by natural and hatchery fish, with hatchery and natural steelhead and marked and unmarked coho salmon exhibiting most bird marks and greatest scale loss; steelhead also exhibited most injuries. Injury to the caudal fin was also common among species of both origins. Condition was poorest during the migration peak. Natural fish were commonly infested with black spot disease. All natural and hatchery fish submitted for disease analysis tested positive for the presence of the Rs antigen (BKD), though ELISA values were mostly low to moderate. There was no evidence of disease-causing viruses or bacteria.

\section{Lamprey Monitoring}

We captured nearly 500 juvenile lamprey and 1 adult lamprey between October and March; macrophthalmia (metamorphosed lamprey) peaked in December and larvae peaked in February. Capture was positively correlated with flow. Estimated trap efficiency was $0.8 \%$; estimated abundance was near 17,000 macrophthalmia.

\section{Migrant Abundance and Survival}

Overall survival was slightly better for yearling fall chinook salmon (41.2\%) than spring chinook salmon (34.7\%). Within spring chinook salmon release groups, fish from Carson Hatchery survived the best. Survival estimates for spring chinook salmon from Little White Salmon Hatchery were similar to those for fish reared at Umatilla Hatchery, even though BKD was a problem for Little White Salmon fish. Umatilla spring chinook salmon acclimated over winter appeared to have a survival advantage over other rearing strategies. Of tagged subyearling fall chinook salmon released in late May, 64.6\% survived, with survival higher for fish acclimated at RM 73 than at RM 56. Summer steelhead released in early April (large-grade) survived better $(61.0 \%)$ than those released in late April (small-grade, 52.4\%). Of the early releases, steelhead released at Minthorn survived best. 
Estimated survivals for tagged natural coho salmon and summer steelhead were $13.6 \%$ and $60.0 \%$, respectively. Survival was highest for fish tagged and released in the upper mainstem Umatilla River compared to tributaries. Estimated abundance of natural chinook salmon (46,764 fish) includes spring and fall chinook races. Estimated abundance of natural coho salmon $(31,709$ fish) and natural summer steelhead $(81,759$ fish) is an increase over past years.

\section{Reach-Specific Survival}

Survival was determined for PIT-tagged release groups of different hatchery species released in the Umatilla River from RM 80 to RM 9. All groups exhibited a decreasing trend in survival with increased rivermile of release, especially summer steelhead where the difference was significant. Columbia River detection of subyearling fall chinook salmon released at the mouth of the Umatilla River was significantly greater than other reach release groups. Total detections of spring chinook salmon and summer steelhead from Umatilla and Columbia River sites showed significant differences in minimum survival between upper and lower reaches.

\section{Environmental Conditions and Bypass Operations}

River flows were highest in mid-December and through March to mid-April. Flow peaked at $2,573 \mathrm{ft}^{3} / \mathrm{s}$ in mid-April. Flows were negatively correlated with Secchi depth and water temperature. Secchi depth ranged from $<0.5 \mathrm{~m}$ to $>2 \mathrm{~m}$ and water temperature ranged from 39 ${ }^{\circ} \mathrm{F}$ (January) to $73^{\circ} \mathrm{F}$ (July).

Detections of hatchery spring and fall chinook salmon were negatively correlated with flow and positively correlated with temperature and Secchi depth. Other species had variable linear associations with flow, temperature, and Secchi depth, except hatchery subyearling fall chinook salmon and large-grade steelhead had none. Further analysis with delta flow and temperature regimes elucidated non-linear relationships with natural fish movement.

Travel speed of fish released for reach survival tests was variably associated with mean river flow and delta river flow (maximum-minimum). Travel speeds were lower for upper releases of spring chinook as flows increased and higher for subyearling fall chinook salmon as flow decreased; lower releases were not affected by flows. Travel speed of large-grade steelhead was positively associated with mean flow and delta flow.

Diversion rate at West Extension Canal influenced trapping efficiency only for hatchery fall chinook salmon and natural chinook salmon. Phase I pumping and the associated reduction in diversion altered fish use of the bypass facility. Water releases from McKay Reservoir aided movement of late season hatchery and natural migrants. Subyearling fall chinook salmon peaked in their migration during water releases from McKay Reservoir. 


\section{Resident Fish and Predators}

Resident fish included 14 major species, with various life stages prevalent within specific periods. Northern pikeminnow abundance increased late in the season. Eight species of avian predators were observed, most notably gulls and cormorants. Gull presence increased with lower flows and higher salmonid abundance in May. Feeding niches were apparent for different species in and around Three Mile Falls Dam.

\section{Management Implications and Recommendations}

1. Support the installation of a remote interrogation system at the east-bank fish ladder of Three Mile Falls Dam, primarily for detection of returning adult salmonids and secondarily for juvenile migrants. This system would provide estimates on smolt-to-adult survival and elucidate passage behavior of juveniles around the dam.

2. Continue to provide minimum summer flows with McKay Reservoir releases, coupled with Phase I pumping, to allow full life-history expression and provide improved habitat and passage conditions for juvenile salmonids, for juvenile and adult Pacific lamprey, and for improved ecological conditions in general. Successful natural production requires a diversity of life stages and strategies that are dependent on appropriate flow conditions year round.

3. Continue transplanting adult fall chinook salmon from mid-Columbia hatcheries into the Umatilla River to assess success of re-establishing natural production, but only if concomitant flows are provided for juvenile life stages. This strategy continues to successfully produce progeny to varying degrees.

4. Manage avian predators, especially at Three Mile Falls Dam. A variety of avian predators are opportunistically preying on juvenile salmonids at their most vulnerable location and during poor migration conditions (low flows).

5. Continue releasing small-grade summer steelhead from the lower acclimation site at Minthorn and continue combined volitional and forced releases of all steelhead groups. Another release year at Minthorn for steelhead smalls will provide additional information on the suitability of this release site for improving migration success.

6. Discontinue the use of Bonifer acclimation site for steelhead larges and release these fish as low in the basin as practical. Six years of data from outmigration monitoring has shown this site to be less than optimal for producing successful migrants. The Minthorn acclimation site appears to be a better release site for steelhead larges.

7. Release large-grade summer steelhead at a later date. A later release would assure more fish are smolted, reduce their residency time in the river, and possibly boost migrant survival. 
8. Continue the over-winter rearing and acclimation of spring chinook salmon from Umatilla Hatchery. This strategy appears to provide a survival advantage. Consider increasing the proportion of the spring chinook production that is over wintered.

9. Acclimate subyearling fall chinook salmon for a second year at the RM 56 acclimation site to provide additional data. This site has potential as a lower-river release location and has not been thoroughly tested. It is also in close proximity to the confluence of McKay Creek (RM 52), which carries cooler water during McKay Reservoir releases.

10. Ensure subyearling fall chinook salmon are of a sufficient size and fully smolted at release to facilitate and strengthen imprinting. The speedy migration of these fish may be a factor in straying, especially if fish are not imprinted.

11. Manage predators in the lower river. Bass species and northern pikeminnow are becoming more abundant and undoubtedly affect survival of primarily subyearling migrants.

12. Managers and facility operators need to be aware of the affect changes in canal operations have on fish passage. Fish can be delayed at canal facilities if attraction water is not provided. During Phase I pumping at West Extension Canal, the elimination of canal diversion inhibits fish movement. Operation of the river-return pipe is one means of providing extra attraction flow during this operational scenario.

13. Continue to rear yearling fall chinook salmon for the Umatilla program at Bonneville Hatchery and one group of spring chinook at Carson Hatchery. These fish show good migrant survival.

14. Continue monitoring lamprey year round to provide data on life history characteristics in the lower river and to monitor the success of the Lamprey Restoration Program. 


\section{INTRODUCTION}

The Umatilla River historically supported large runs of salmon (Oncorhynchus spp.), steelhead (O. mykiss), and Pacific lamprey (Lampetra tridentata) for productive Tribal fisheries, and good sport fisheries in the 1800s and the beginning of the last century. By the 1920s, these runs were decimated. The extirpation and degradation of salmon and steelhead populations in the Umatilla River was a result of extensive agricultural development and associated water withdrawals, habitat destruction, water quality degradation, and passage problems within the subbasin, and over-harvest and habitat loss outside the basin (Saul et al. 2001).

The Northwest Power Act of 1981 was the springboard for focusing attention and effort on restoring these once productive runs throughout the Columbia River basin. The successive Fish and Wildlife Programs of the Northwest Power Planning Council (NPPC 1984, 1987, 1994) and the Comprehensive Plan for fisheries rehabilitation in the Umatilla River (Boyce 1986) articulated the necessary flow enhancement and fishery rehabilitation projects that were necessary in the Umatilla River basin to restore anadromous fish populations. These included passage improvements at irrigation diversions, habitat restoration, hatchery production, holding and acclimation facilities, flow enhancement, and fish transport during low flows. Rehabilitation of anadromous fish stocks in the Umatilla River basin called for restoration of spring and fall races of chinook salmon (O. tshawytscha), coho salmon (O. kisutch), and enhancement of summer steelhead (CTUIR and ODFW 1989). Recently, Pacific lamprey restoration has become part of the overall restorative process (Close, In preparation). Detailed scope and nature of the habitat, flow, passage, and fish production projects are in the Umatilla River basin fisheries restoration plans (CTUIR 1984; Boyce 1986). The Umatilla Hatchery Master Plan (CTUIR and ODFW 1990) provides the framework for hatchery production and evaluation activities. Many agencies cooperate, coordinate, and exchange information in the Umatilla basin to ensure successful implementation of rehabilitation projects, including the Oregon Department of Fish and Wildlife (ODFW), the U.S. Bureau of Reclamation (USBR), the Bonneville Power Administration (BPA), National Marine Fisheries Service (NMFS), the Oregon Water Resources Department (OWRD), the Confederated Tribes of the Umatilla Indian Reservation (CTUIR), and local irrigation districts (West Extension, Hermiston, and Westland). The Umatilla River Operations Group and the Umatilla Management, Monitoring and Evaluation Oversight Committee coordinate river and fisheries management and research in the Umatilla River basin. The Umatilla Hatchery and Umatilla Basin annual operation plan (AOP) guides the artificial production programs for the Umatilla River.

Over the past fifteen years, the Fisheries Restoration Program in the Umatilla River Basin has resulted in increasing numbers of juvenile salmonid migrants and adult returns as artificial production has increased through the Umatilla Hatchery program and natural production has been enhanced through supplementation and reintroduction efforts. Improvement in habitat, flows (Phase I and II exchanges; USBR and BPA 1989), and passage facilities has further bolstered the fisheries restoration effort. Monitoring and research efforts to evaluate these specific restoration and enhancement projects were immediately implemented as projects were 
initiated or completed. For example, passage evaluation studies followed new construction of canal screening and bypass facilities on the Umatilla River (Knapp and Ward 1990, Hayes et al 1992, Cameron and Knapp 1993, Cameron et al. 1994, 1995, 1997). Monitoring and evaluation of the experimental Umatilla Hatchery was implemented at the onset of hatchery operations in the early 1990s and is ongoing (Keefe et al. 1993, 1994; Hayes et al. 1996a, 1996b; Focher et al. 1998; Hayes et al. 1999a, 1999b; Stonecypher et al. 2001, Chess et al. 2002). Monitoring and evaluation of natural production in the Umatilla River was initiated as returning hatchery fish reestablished and supplemented natural salmon and steelhead populations (CTUIR 1994; Contor et al. 1995, 1996, 1997, 1998, 2000).

However, project-specific monitoring and evaluation efforts did not include an overall evaluation of migration success and survival of hatchery-reared and naturally-produced juvenile salmonids to the lower Umatilla River. Long-term trend monitoring for abundance and survival was considered valuable as habitat was improved, flow enhanced, natural production expanded, and hatchery practices adjusted. In-basin survival needed to be addressed to answer critical uncertainties in the short term relative to overall survival in the long term. Monitoring and sampling in the lower river was considered crucial for gathering the necessary information on life history characteristics, lower river production, abundance, and smolt-to-adult survival of all natural salmonids. Specific questions regarding in-basin survival and passage problems for juvenile fish, production potential for natural stocks, and aquatic community health have arisen over the years. Furthermore, as production strategies evolved in the subbasin, results needed to be monitored and merits evaluated to help guide management decisions. In addition, supplemental information was needed by specific research and monitoring projects that could not be obtained through the projects themselves. Or, some projects and programs in the basin lacked a monitoring and evaluation component.

Evaluation of juvenile salmonid outmigration and survival in the lower Umatilla River basin has become the necessary component for determining the success of some projects, monitoring the effects of others, assessing the overall effectiveness of the rehabilitation plan, and for providing critical information on juvenile migrants. Beginning in fall of 1994, the Outmigration and Survival Study followed the completion of Passage Evaluation studies. This succeeding project was intended to be long term and broader in scope, although concerns with juvenile passage at Three Mile Falls Dam remained and needed to be addressed. Although we have been able to address many of the original critical uncertainties, annual changes in hatchery practices, environmental conditions, production strategies, flow enhancement, and technological advancement have retained the need for the information provided by this project.

Information on migration success and performance of different rearing and release strategies for salmonid species within the Umatilla River supplements the evaluation of specific practices at Umatilla Hatchery. Strategies for rearing at Umatilla Hatchery include use of standard Oregon raceways and oxygenated Michigan raceways. Some production groups released into the Umatilla River are also reared at other hatcheries. Monitoring in the lower river also supplements upriver natural production monitoring and is crucial for determining movement patterns, migration timing, lower river abundance, and survival of naturally-produced salmonids. Also addressed are factors affecting survival of juvenile salmon in the Umatilla basin, including loss through in-river predation, cumulative effects of passage through facilities at irrigation 
diversion dams, effects of poor river conditions and transport on fish health, effects of hatchery rearing and release strategies, and effects of flow enhancement.

Previous outmigration monitoring of juvenile salmonids discerned different hatchery rearing groups through branded and color-marked fish (Knapp et al. 1996, 1998a, 1998b, 2000). The advent of PIT-tag detection at John Day Dam in 1998 prompted the initial use of PIT (Passive Integrated Transponder) tags (400 Khz) on hatchery fish in the Umatilla River basin the same year. Upgrading to $134 \mathrm{Khz}$ tags and detection systems in the mainstem in 2000 also prompted an upgrade in the Umatilla River. Remote interrogation in the lower Umatilla River promises to be a strategic change in methodology for monitoring the outmigration of juvenile fish.

Estimates of survival have been less than optimal for many groups of fish in past years (Knapp et al. 1996, 1998a, 1998b, 2000; Ehlers et al. 2001). Release site (river mile distance) was thought to be a factor affecting survival. PIT tagging and monitoring in 1998 and 1999 (Knapp et al. 2000, Ehlers et al. 2001) and again this year provided an opportunity to conduct reach-specific survival tests with PIT-tagged fish and gain a more detailed understanding of the effects of release site on survival and migration success.

A number of issues related to water use in the Umatilla River are associated with fisheries rehabilitation. Providing water for irrigators and anadromous fish is a desired goal of the Umatilla Basin Project (USBR 1988). An understanding of flow requirements for fish passage, rearing, and survival, and species-specific migration characteristics is critical to determine optimum canal operations, water release strategies, and flow enhancement strategies (USBR 1988, USBR and BPA 1989). Phase I pump exchange at West Extension Canal affects the efficiency of the bypass in routing fish past Three Mile Falls Dam (Knapp et al. 1996, 1998a, 2000; Ehlers et al. 2001). Water releases from McKay Reservoir are important in allowing instream migration of juvenile migrants in late spring (Knapp et al. 1998a) and throughout summer (Knapp et al. 2000; Ehlers et al. 2001). Assessing these effects is done through monitoring at the bypass sampling facility and, in the past, partly through video monitoring at the east-bank ladder (Knapp et al. 1998b, 2000). In addition, species life history diversity is dependent on sufficient flows and water quality conditions. Flow measures have now expanded to cover this aspect of salmonid production.

The goal of the Outmigration and Survival Study is to evaluate the outmigration and estimate the survival of juvenile salmonids in the lower Umatilla River basin and investigate the various factors affecting migration and survival for the purpose of facilitating resource management and management direction. General objectives for meeting this goal in the 19992000 project period were:

1. Use PIT-tag technology to monitor tagged hatchery and natural juvenile salmonids emigrating from the Umatilla basin.

2. Determine migration performance and pattern, migrant abundance, and survival of PITtagged hatchery and natural juvenile salmonids in the lower Umatilla River.

3. Investigate effects of river and canal flow, water temperature, and other environmental variables on fish migration. 
4. Monitor the movement of juvenile Pacific lamprey in the lower Umatilla River and estimate trapping efficiency and abundance.

In this report, we describe our sixth-year activities and findings for the Umatilla River Outmigration and Survival Study from 1 October 1999 to 30 September 2000. We present information from outmigration monitoring and remote interrogation, including species, origin, health, and lengths of fish collected, PIT-tag detections, migration patterns, and migration performance. We present trapping efficiencies, estimations of migrant abundance and survival, information on reach-specific survival, and effects of environmental conditions on fish movement. We also include observations of resident fish and avian predators and results of monitoring anadromous lamprey. 


\section{STUDY SITES}

Tagging and holding of fish groups for reach-specific survival tests was conducted at Irrigon Fish Hatchery (Figure 1). Releases for reach-specific survival tests were made at various points near Hermiston (RM 9.8), Echo (RM 27.3), Rieth (RM 48.5), and specific acclimation sites above Pendleton (Figure 1).

We collected outmigration data from two sampling sites during 1999-2000. These sites included one in-river location below Three Mile Falls Dam and the canal screening facility at West Extension Canal (Three Mile Falls Dam). We collected data from October through early March using a 5-ft-diameter rotary-screw trap located in the lower river underneath the I-82 bridge (RM 1.2; Figures 1 and 2). This site was used when the canal facility was not operating. Descriptions of the rotary-screw trap and its deployment are included in Knapp et al. 1998a and 1998b. We conducted trap efficiency tests for juvenile Pacific lamprey at the rotary trap, but not for salmonids; the release site was located just below Three Mile Falls Dam (RM 3.7) in a deep pool. We collected data at the West Extension Canal bypass facility (RM 3.7) at Three Mile Falls Dam during the irrigation season beginning in March and extending into early October 2000 (Figure 2). At this facility, fish could be routed into the sampling facility and held for observation or be directed through a remote interrogation system and back to the river. The remote interrogation system used in 1998 - 1999 was replaced with a new $134 \mathrm{kHz}$ system for the $1999-2000$ season (Figure 3). Releases for the bypass facility's trap efficiency tests were made upriver at the Hermiston Waste Water Treatment Plant (RM 5.0; Figure 1).

Canal operations varied throughout the sampling season, affecting the degree of attraction flow guiding fish into the sampling facility. If canal diversion was reduced or eliminated, one of two methods was deployed to provide attraction flow. These methods included opening a 21-in pipe returning water to the river (river-return pipe) or turning on one or two pumpback pumps that circulate water through the bypass system. Further details on the operation of this canal and bypass facility can be found in Knapp et al. 1996.

During low river flow, fish passage in the lower river is enhanced by pumping Columbia River water into West Extension Canal in lieu of diverting Umatilla River water (Phase I exchange). During full Phase I exchange, all canal flow is supplied by pumping, and water flowing through the bypass system is returned to the river. River flow is additionally augmented at times through releases of stored water from McKay Reservoir (Figure 1).

\section{METHODS}

\section{Outmigration Monitoring}

\section{PIT-Tag Operations}

A new remote interrogation system $(134 \mathrm{kHz})$ was installed at West Extension Canal to interrogate PIT-tagged fish. This system replaced the old $400 \mathrm{kHz}$ system used in 1999 (Ehlers et al. 2001). Remote detection (passive interrogation) at the canal operated $24 \mathrm{~h} /$ day, except 
during sampling when we actively interrogated fish. For passive interrogation, fish that entered the canal trap were diverted to a six-inch PVC pipe that was encircled by two loop antennae connected to two electronic transceiver units, or readers (International Standards Organization (ISO) portable transceiver system - Destron Fearing FS2001); Figure 3). Once fish passed through the antennae, they were returned to the bypass downwell via a pipe extension. The two portable transceiver systems were connected to a laptop computer via a serial port hub. Except for the loop antennae, all electronic systems were housed in a protective plexiglass chamber in close proximity to the interrogation pipe (Figure 3). We used a Minimon program (developed by Pacific States Marine Fisheries Commission; PSMFC) to store tag codes into an interrogation file, with an associated date and time stamp, and to log system operations. A new interrogation file was created every 6-12 h or when a file was manually closed. On a daily basis, interrogation files were saved to a floppy disk for transfer to a desktop hard drive at the office where they were uploaded to the PTAGIS database, operated and maintained by PSMFC in Gladstone, OR.

We conducted twice daily efficiency tests for the remote detection system using sticks embedded with known PIT-tag codes. The 4-in-long x 1-in-diameter sticks were attached to a secured string and placed in the flume above the interrogation pipe and allowed to float freely through the pipe to simulate fish movement. After the sticks passed through, they were retrieved and the detected codes noted.

We tagged fish of various species, races, and origins with $134 \mathrm{kHz}$ PIT tags for several purposes and tests. Hatchery fish were tagged for trap efficiency and reach-specific survival tests. Natural fish were tagged for trap efficiency tests and some natural fish were tagged to supplement the Tribal tag database. Tags were obtained from PSMFC.

Prior to tagging, we set up a tagging file in the new PITTag2 program on a laptop computer to record codes of implanted tags and to track the number of fish tagged. All fish were anesthetized with MS222 (tricaine methanosulfonate) and scanned for PIT tags prior to injection of a new tag. Fish were tagged according to standards outlined in the PIT Tag Marking Procedures Manual (CBFWA, PIT Tag Steering Committee, 1999). Immediately after tagging, fish were scanned with the portable transceiver system to read and send the code directly to the tagging file. If length data was taken, it was entered into the computer file along with the tag code. If the laptop computer was not available, we scanned fish and stored tag codes directly to the portable reader and later downloaded those codes into a computer file. Tagging files were submitted to the PTAGIS database on a regular basis.

During sampling at West Extension Canal and the rotary trap, we hand interrogated (active interrogation) all sampled fish for PIT tags (except coho salmon, which were not tagged). Using the PITTag2 program on a laptop computer and a portable transceiver system, we scanned codes from PIT-tagged fish into a monitoring file. A new monitor file was created for each day. If the laptop computer was not available, we stored codes on the reader and downloaded the data at the office. Fish were placed in a recovery tank after interrogation and released into the river when recovered.

This was the second year that natural fish were PIT tagged in the upper Umatilla River by CTUIR. CTUIR selected natural fish for tagging based on size, with the assumption that larger 
fish were actively migrating. Natural spring chinook salmon, coho salmon, and summer steelhead were tagged. Production releases of tagged hatchery fish included yearling spring and fall chinook salmon, subyearling fall chinook salmon, and summer steelhead. These fish were tagged by staff from the Umatilla Hatchery Monitoring and Evaluation project. Hatchery coho salmon were not PIT tagged in 2000.

All tagging and monitoring files were edited and validated through the PITTag2 program. Interrogation files required no editing or validation. We uploaded all files to PTAGIS via the Internet and downloaded interrogation reports to ascertain derivation of interrogated tags included in the monitoring and interrogation files.

Columbia River detection sites were operating by early April 2000. We downloaded tag information from PTAGIS to determine detections of our tagged test fish at mainstem Columbia River dams (John Day and Bonneville dams) and in the Columbia River estuary, and for tag recoveries at Columbia River islands. Island tag recoveries reflected predation by birds.

We did not pursue design of an interrogation system at the east-bank adult fish ladder due to the infancy of this technology. Prototype mainstem interrogation systems at Bonneville Dam were still being developed.

\section{Trap Efficiencies}

Trap efficiency tests for juvenile salmonids were conducted only at West Extension Canal (RM 3.7). Tests were conducted with hatchery and natural PIT-tagged fish and were species specific. We used trap collection efficiencies to expand the detections of tagged and untagged fish for an estimate of migrant abundance. A final trap collection efficiency estimate was a multi-step process that involved determining the probability of survival of tagged fish released for trap efficiency tests and the detection efficiency of the remote detector (see PIT-Tag Operations).

We collected only healthy, untagged hatchery and natural fish from the sampling facility at West Extension Canal for trap efficiency tests. On occasion (29 - 31 March and 8 April), hatchery spring, fall, and unknown chinook salmon were collected at the rotary-screw trap (RM 1.2) for use in tests at West Extension Canal. Fish collected for trap efficiency tests were held in net pens until enough fish $(50-75)$ were available to conduct the test. Net pens were held in a large circular tank supplied with inflow water from the canal; fish were tagged at a station adjacent to the holding tanks. Test hatchery fish included yearling spring, fall, and unknown chinook salmon, subyearling fall chinook salmon, and summer steelhead. We mostly used unclipped fish for tests; the exception was the use of AD- and ADLV-fin clipped summer steelhead and some AD-fin clipped chinook salmon of unknown race. Test natural fish included subyearling chinook salmon and summer steelhead.

Tests were generally conducted two times per week for each species and race of fish while sufficient numbers were being captured. We tagged fish with $134 \mathrm{kHz}$ PIT tags and scanned codes directly into a PITTag 2 file on a laptop computer. A new tagging file was created for 
each test and species. After tagging, fish were held in special net pens within circular tanks for $24 \mathrm{~h}$ to assess latent mortality (tagging effect) and loss of tags. These special net pens incorporated a large-meshed false bottom, which allowed ejected tags to fall through to the small-meshed bottom of the pen where they were safe from fish consumption. We recorded water temperature at the start and end of holding. Ejected tags and mortalities were collected, counted, and scanned at the end of the holding period. If a dead fish had no tag, an ejected tag was attributed to that fish. The number of fish that died during the 24-h holding period was used to assess the probability of survival $(s)$ of remaining fish released for each test.

Tagged, live fish were transported to the release site at the Wastewater Treatment Plant (RM 5.0, Figure 1) in an un-insulated, aerated, 300-gal slip tank. Releases were generally made in late afternoon or early evening. At the release site, transport mortalities were retained, scanned, and codes recorded. Fish were released via a flex hose attached to the slip tank and a 10-in PVC pipe leading to the river. River temperature was recorded at the time of release.

All codes from ejected tags and mortalities were removed from the tagging file. A total count of ejected tags was used to determine percent tag retention; tag retention was not used in adjusting the trap efficiency estimate. We assumed that tag retention would be $100 \%$ after release. All ejected tags and mortalities were accounted for when determining the total number of tagged fish released for each test. The final release number $(N)$ was then adjusted for expected survival $(s)$ to obtain the adjusted number of tagged fish available for detection $(M$; $N(s)=M$ ). We assumed no mortality of fish from factors other than tagging effect after their release.

Trap efficiency test fish were detected at West Extension Canal via the remote detector or during hand sampling (see PIT-Tag Operations). Detections $(R)$ were adjusted by remote detection efficiency. We downloaded PTAGIS reports on a regular basis to determine the number of detected fish from each trap efficiency release group.

Trap efficiency estimates (TE) were determined by using the adjusted number of tagged fish released upstream of the trap $(M)$ and detections of test fish $(R)$ at West Extension Canal from each test group $(T E=R / M)$. For each species group, we compared separate trap efficiencies using $\mathrm{Chi}^{2}$ analysis and pooled the test data if the efficiency estimates were not significantly different at an alpha level of 0.05 . (If detections were $<5$, test data was combined with an adjacent test until the detection sample size was $\geq 5$ to satisfy the limitations of the Chi ${ }^{2}$ test). Pooling was continued until a significant difference was determined. A final trap efficiency estimate was the weighted mean of the sub-pooled estimates. Singular or sub-pooled efficiency estimates were used to determine abundance of tagged fish (see Abundance and Survival).

\section{Collection}

Fish were collected to determine species composition trends, to collect biological data, and to obtain fish for trap efficiency tests. Biological data included length (FL), fin clip, and condition and was collected on subsamples of fish throughout the season. Juvenile fish were anesthetized using a stock solution of MS222 (40 mg/l) before evaluation. We scanned all fish 
for PIT tags and used a tabletop metal detector to determine the presence of a wire tag. Codes of tagged fish were transferred into the PITTag2 program file. We identified and counted all juvenile salmonids by species, race, and origin (hatchery or natural; Figure 4). Hatchery spring chinook salmon (yearling) were primarily differentiated from natural fish by their larger size (generally $>100 \mathrm{~mm} \mathrm{FL)}$ or poorer condition (i.e., higher degree of scale loss or fin erosion). Experienced samplers could also separate hatchery spring chinook from natural salmon based on how the fish looked. Hatchery chinook salmon with an adipose-fin clip and a coded-wire tag were not distinguishable between spring and fall races; these fish were generically designated as chinook salmon. Coho salmon not possessing an adipose-fin clip were difficult to distinguish from natural coho salmon and were therefore designated as unknown origin. However, to estimate abundance of natural coho we also designated fish $<100 \mathrm{~mm}$ FL to be of natural origin, and some fish $>100 \mathrm{~mm}$ that appeared to be of natural origin based on experienced observation. Natural salmon fry were also identified as chinook or coho salmon.

All fish collection data was recorded directly into the PITTag2 program file using a CalComp Drawing Board III (digitizer). The digitizer was connected to the computer via a Biomark multiport unit (Figure 5). A map of all biological information was created for the digitizer board. A metric ruler was also included for measuring fish lengths. The digitizer board was housed in a clear box made of Lexan and included a platform for holding fish atop the metric ruler. As information was collected, data was electronically entered into the PITTag2 program by touching the attached stylus to the appropriate cells on the map or onto the ruler. PIT-tag codes were only registered for PIT-tagged fish; otherwise the code cell was "dotted out".

Scale samples (three scales from each side) were taken on a subsample of smolted natural summer steelhead. To determine origin of smaller, unmarked salmon, scales were taken from chinook and coho salmon less than $120 \mathrm{~mm}$ FL. A few samples were also taken from larger coho salmon ( $>170 \mathrm{~mm}$ FL) to determine origin. CTUIR biologists analyzed scale samples for age and origin clarification.

Sample data for each species collected at the rotary-screw trap was expanded to account for times when the trap was not sampling (during a trap check), determined by dividing the hours sampled by the total number of hours available to sample (i.e., $24 \mathrm{~h} / \mathrm{d}$ ). We did not include in the expansion days when the trap was not fishing due to high river flows. On occasions when the trap was temporarily stopped upon arrival at the trap (due to a debris jam), we recorded the end of the sample period as the time of the trap check.

We sampled at West Extension Canal periodically throughout the day and occasionally overnight. The percent of time spent sampling at West Extension Canal was determined by dividing the hours sampled by the total number of hours available to sample (i.e., $24 \mathrm{~h} / \mathrm{d}$ ). The average number of hours sampled per day was also determined. When not sampling, fish were directed through the remote detection system (bypassed); the percent of time spent bypassing fish was also calculated. 


\section{Migration Parameters}

We determined migration pattern, timing, and duration of detection, identified dates of peak movement, and calculated median travel speed for hatchery and natural migrants using PIT-tag detections. Migration parameters were analyzed for production fish, reach-specific survival test fish, and natural fish. Detection duration was the length of time from initial to final detection. Migration timing was the cumulative percent detection of a fish species over time. Migration patterns and periods of peak movement were identified from a plot of daily detections through time. Median detection was the $50^{\text {th }}$ percentile detection. Travel speed was estimated by dividing median travel time calculated from all detected fish by the miles from release to detection site; median travel time was based on forced release date. We determined diel movement of PIT-tagged fish by plotting the exact time when tags were detected through the remote interrogation system.

We determined travel time to John Day and Bonneville dams on the lower Columbia River for reach-survival test fish. We documented fish consumed by terns or gulls by subsequent tag retrieval from mainstem island colonies.

\section{Lengths}

We measured fork length (FL) to the nearest millimeter ( $\mathrm{mm}$ ) of all natural salmonids and a portion of hatchery salmonids, including PIT-tagged fish. Portions of test fish used in reachspecific survival tests were also measured, by each separate replicate release group. On a monthly basis, we estimated minimum, maximum, and mean fork length for each species and race of hatchery and natural fish.

\section{Fish Condition and Health}

Subsamples of hatchery and natural fish were examined for scale loss and other bodily injuries to determine fish condition. We categorized scale loss following criteria used by the Umatilla Hatchery Monitoring and Evaluation study (Keefe et al. 1994). We considered fish health "good" if cumulative scale loss on either side of the fish was less than $3 \%$. We considered fish "partially descaled" if cumulative scale loss exceeded $3 \%$ but was less than $20 \%$ on either side of the body, and "descaled" if cumulative scale loss equaled or exceeded $20 \%$. We determined the proportion each condition category comprised of total fish examined. We also examined fish for external parasites and other injuries to the head, eyes, operculum, body, and tail. We noted fungal infections on the body surface, indications of bacterial kidney disease (bloated belly, pop-eye, jaundice coloration), and bird marks. Symmetrical bruises on each side of the fish indicated bird marks.

Fish mortalities were noted by species and identified as to whether the fish died prior to or during sampling. Percent sampling mortality and natural mortality were estimated separately. Percent mortality (either type) was determined from the total number of fish sampled, not just examined. All dead natural fish and some diseased and dead hatchery fish were examined by the 
ODFW Fish Pathology Lab to determine fish health status. Unusual marks or indications of disease on dead fish were also noted.

\section{Lamprey Monitoring}

Pacific lampreys were captured while sampling at the rotary-screw trap (1 October $1999-2$ March 2000) and West Extension Canal (6 March - 30 September 2000). CTUIR biologists also sampled and captured lampreys at the rotary-screw trap from 3 March to 17 April 2000. As with salmonids, lampreys were anesthetized with a stock solution of MS222 before evaluation. Stage of development for juveniles was determined by classifying lampreys with brown coloration and unidentified eyes and mouth as larvae and lampreys with silvery coloration and visible eyes as macrophthalmia; lampreys that were large (>200 mm TL) and fully developed were considered adults. All lampreys were counted and their total length measured ( $\mathrm{mm}$ ) by stage of development.

Trap efficiency tests were performed only at the rotary-screw trap with macrophthalmia. After being anesthetized and measured, we marked each individual by taking a small clip ( $1-2$ $\mathrm{mm}$ ) from the caudal fin using small scissors. We held marked lampreys for $24-48 \mathrm{~h}$ in a perforated bucket in the river. After holding, mortalities were counted and removed from the test group. All live, marked lampreys were then transported in buckets to the release site, 2.5 miles upstream. Lampreys were released in a pool directly below Three Mile Falls Dam (RM 3.7).

We developed length-frequency distributions by calendar quarter and calculated overall mean lengths for larvae and macrophthalmia. We also plotted river flow $\left(\mathrm{ft}^{3} / \mathrm{s}\right)$ at $\mathrm{RM} 2.1$ against number of lampreys captured (larvae and macrophthalmia) over time and used the Pearson Correlation to determine a linear relationship. CTUIR capture data was incorporated into all analyses.

\section{Abundance and Survival}

\section{Migrant Abundance and Survival}

We estimated migrant abundance for each race or species of salmonid that was PIT tagged to estimate total outmigration and survival of tagged hatchery and natural fish. This was accomplished through tag detections at the canal facility. We also estimated abundance of natural fish sampled at the rotary trap and canal trap. We estimated migrant abundance $(A)$ of tagged fish at Three Mile Falls Dam by multiplying the number of fish detections (D) by the reciprocal of the trap efficiency $(T E)$ estimate $(A=D \times 1 / T E$; Burham et al. 1987; Dauble et al. 1993). Since detections were date specific, we used efficiency estimates that encompassed the dates tags were detected. These were either singular or statistically subpooled estimates (see Trap Efficiencies). If no trap efficiency estimates corresponded to the dates tags were detected, we arbitrarily pooled trap efficiency data from the closest daily estimates before and after the detection date. For example, a detection on 5 June, with no corresponding trap efficiency estimate, was expanded by pooling the release and recapture numbers from trap efficiency tests 
conducted on 3 June and 7 June. We summed the subtotals of abundance for a total abundance estimate over the collection period (March - June). We used the Bootstrap method (Efron and Tibshirani 1986; Thedinga et al. 1994) with 1,000 iterations to determine a variance for each abundance estimate. Variances for abundance subtotals were summed to derive an overall variance. Confidence intervals $(95 \%)$ for the abundance estimate were calculated using the square root of the variance estimate $(\mathrm{CI}=1.96 \sqrt{ } \mathrm{V})$.

We estimated natural fish abundance by relying on several expansion factors to extrapolate for missing data. Total abundance of tagged and untagged fish combined was determined on a monthly basis and summed for the season. At West Extension Canal, count of fish from hand sampling was expanded by the sample rate during the specific sampling period $(C)$. We generally sampled within a block of time during the day, but some of the time was not sampled within this block. We adjusted $C$ by the portion of time sampled $(T)$ to account for unsampled hours within the block. Sampling blocks were determined on a month-by-month basis. Using the monthly diel pattern of movement through the facility (from tag detections), we determined the proportion of the diel distribution that the sampling block encompassed $(D)$ to make a final adjustment for number bypassed through the facility $(B=(C / T) / D)$ for each month. Monthly abundance (or passage) was derived by expanding number bypassed $(B)$ by the average trap efficiency $(T E)$ for each month $(A=B / T E)$ for each species. Monthly estimates were summed for a total season abundance estimate. For months where trap efficiencies for natural fish were not available or were sparse, we used estimates from hatchery conspecifics to supplement the average estimate. (At times, we used estimates from other species as surrogates.) Also, if hatchery conspecific efficiencies were not available for that month, we used estimates from the month before or month after.

To estimate abundance of natural fish at the rotary-screw trap, capture number was adjusted by the proportion of time sampled, trap retention efficiency, and a trap efficiency estimate. For natural chinook salmon, we used the trap efficiency estimate derived for hatchery spring chinook salmon in 1998 (Knapp et al. 2000). We assumed natural chinook salmon would be 100\% retained in the trap due to their small size. Since no retention efficiency estimates were available for natural or hatchery steelhead, we assumed a 50\% retention efficiency based on a 77\% efficiency estimate for hatchery spring chinook salmon in 1998 (Knapp et al. 2000). Similarly, since no trap efficiency estimates were available for natural or hatchery steelhead, we used a trap efficiency estimate of $1 \%$, assuming the efficiency for natural summer steelhead would probably be around half that of yearling spring and fall chinook salmon (2.1 - 3.7\%; Knapp et al. 2000) due to their ability to avoid the trap (determined from sampling in 1997; Knapp et al. 1998b).

Survival estimates $(S=A / R)$ for hatchery and natural fish were based on the migrant abundance method (Burham et al. 1987; Dauble et al. 1993) where survival $(S)$ was estimated as the proportion of tagged migrants passing the sampling site $($ Abundance $=A)$ to the number of tagged fish released at upriver sites $(R)$. We used this method to estimate survival of all PITtagged fish groups. The binomial test was used to test for significant differences in survival between production release groups. 


\section{Reach-Specific Survival}

Reach-specific survival tests were conducted for hatchery spring chinook salmon, subyearling fall chinook salmon, and large-grade summer steelhead. To determine reach survival, these fish were released at three lower river locations (RM 48, RM 27, and RM 9) in addition to the standard release site at the respective acclimation facilities (RMs 80, 79, 74, 65, and 56). Furthermore, subyearling fall chinook were released at the mouth of the Umatilla River (RM 0). After PIT tagging, test fish groups were held separately at the hatchery in indoor circular tanks until time of release; therefore, test fish were not acclimated upriver. Mortality was recorded on a daily basis. Tag loss was determined at the end of holding. Tag consumption was identified during tag scanning prior to release; scanning of "double-tagged" fish produced a "no read" at first pass through the reader and then a tag code read at second pass, or two different tag code readings with multiple passes.

Test groups included three groups of spring chinook salmon (777 - 1,002 fish/group), 5 groups of subyearling fall chinook salmon (446 - 1,892 fish/group), and five groups of summer steelhead (381 - 569 fish/group). For each species, test-group releases were split into three consecutive-day releases (replicates), immediately following the normal production release from the acclimation facility. On the day of release, fish were scanned for a PIT-tag code and measured (FL), placed in site-specific 30-gal containers with lids, and transported in an aerated 300-gal slip tank to each release site. Fish were released either by hauling the entire container down to the river or by loading batches of fish in 5-gal buckets for release.

Fish were interrogated in the lower river at West Extension Canal, either through the remote detector or during hand sampling. Fish were also interrogated at mainstem dam sites and in the estuary, and tags recovered at island bird colonies. We searched the PTAGIS database to determine the derivation of all tag detections. Duplicate tags (detected at more than one location) were converted to a singular detection, ascribed to the uppermost site. We assumed fish detected at mainstem locations had survived and exited the Umatilla River. Tagged fish from the lowermost release group at RM 0 were only detected on the mainstem.

Survival was determined by several methods. For detection in the Umatilla River (West Extension Canal), we expanded detections within each replicate release group by corresponding trap efficiencies (as described in Migrant Abundance and Survival) to derive survival estimates for each replicate release and a mean survival estimate for each reach. We determined significant differences in survival among sites using ANOVA with transformed data (arc-sine), followed by Duncans multiple comparison test when ANOVA results were significant. We also derived a relative survival index (mean percent detection for each release site) using all nonduplicative tag detections within the Umatilla and Columbia rivers, including tag recoveries at island bird colonies. We similarly used ANOVA to test for differences among sites. Variances of the means were used to compute $95 \%$ confidence intervals. 


\section{Environmental Conditions and Bypass Operations}

We monitored physical river and environmental conditions at both lower river trap sites to characterize conditions in the Umatilla River and assess their relationship to fish migration. At the rotary-screw trap, we recorded air and water temperatures $\left({ }^{\circ} \mathrm{F}\right)$, debris level, water clarity, and river elevation once daily at the time of check, usually in the afternoon. We also recorded cone rotations per minute after debris removal. At West Extension Canal, we recorded air and water temperatures $\left({ }^{\circ} \mathrm{F}\right)$, water clarity, and bypass operations once daily at 1200 hours. Bypass operations included when each of three pumpback pumps were on or off, when the river return pipe was open or closed, and the opening on each of three headgates. Operation of Phase I pump exchange was noted (on, partial, or off). We recorded river and canal elevations and debris level from one to several times daily.

We measured daily maximum and minimum water and air temperatures using a Taylor MaxMin thermometer. In addition, daily thermograph data (mean temperature) from Three Mile Falls Dam was provided by CTUIR. We categorized debris level as low, moderate, or high. Water clarity was measured to the nearest $0.05 \mathrm{~m}$ using a 7-in-diameter Secchi disk attached to a PVC pipe; we averaged the depth at which the disk disappeared from sight as it was lowered and reappeared in sight as it was raised to obtain a mean Secchi depth. At the rotary-screw trap, we recorded river elevation to the nearest 0.5 in on a staff gauge, and at West Extension Canal, river and canal elevations were recorded to the nearest $0.10 \mathrm{ft}$ above sea level.

River flow data $\left(\mathrm{ft}^{3} / \mathrm{s}\right)$ for Water Year 2000 was obtained from the U.S. Bureau of Reclamation (USBR). Gauging stations are located near Umatilla (UMAO, RM 2.1), Echo (UMUO, RM 28.3), Butter Creek (UBBO, RM 8.5), Dillon (UMDO, RM 24.4), Yoakum (YOKO, RM 37.6), McKay Creek (MCKO, RM 52.0), and Pendleton (PDTO, RM 55.3). Temperature data $\left({ }^{\circ} \mathrm{F}\right)$ from a site at Yoakum (YOKO, RM 37.6) was provided by USBR.

The U.S. Bureau of Reclamation also provided canal flow data for West Extension Canal. Diversion at West Extension Canal was calculated by subtracting the Phase I exchange amount (WEPO gauging station) from the canal flow (WEIO gauging station). The diversion amount was then adjusted to be at least $5 \mathrm{ft}^{3} / \mathrm{s}$ (when the river return pipe was closed) or $20 \mathrm{ft}^{3} / \mathrm{s}$ (when the river return pipe was open) to account for flow running through the bypass channel. Flow above the dam (RM 3.7) was calculated by adding the UMAO and unadjusted canal diversion flow data. Diversion rate was calculated by dividing adjusted diversion amount by flow above the dam.

River flow (RM 3.7 and 37.6) and temperature data was plotted with percent detection of each species for natural fish and hatchery production groups. Flow data from RM 37.6 was chosen to provide a flow reference midway through the migration corridor. The Pearson Correlation was used to determine a linear relationship between percent detection and mean river flow (RM 37.6) and mean temperature (RM 37.6).

Following methods outlined in Roper and Scarnecchia (1999), we calculated the percentage of detections of natural coho salmon and summer steelhead that were recorded during six temperature categories (measured at YOKO, RM 37.6): $<50^{\circ} \mathrm{F}, 50-<54^{\circ} \mathrm{F}, 54-<59^{\circ} \mathrm{F}, 59-<$ 
$63^{\circ} \mathrm{F}$, and $63-68^{\circ} \mathrm{F}$. We also calculated the percentage of time in which those temperature categories existed within each species detection period. Our null hypothesis was that the percentage of the total detections within each temperature category would not differ from the percentage of time that each temperature category comprised within the detection period. Deviations from the null hypothesis were tested using the $\mathrm{Chi}^{2}$ goodness-of-fit test. Detections of natural coho and summer steelhead were similarly tested with river flow and changes in river flow at RM 37.6. Flow categories were: $0-<250 \mathrm{ft}^{3} / \mathrm{s}, 250-<500 \mathrm{ft}^{3} / \mathrm{s}, 500-<750 \mathrm{ft}^{3} / \mathrm{s}, 750-$ $<1,000 \mathrm{ft}^{3} / \mathrm{s}$, and $\geq 1,000 \mathrm{ft}^{3} / \mathrm{s}$. Changes in river flow were categorized as rapidly decreasing $(\geq$ $10 \%$ lower than the previous day), slowly decreasing $(>1-<10 \%$ lower than the previous day), not changing (within $1 \%$ of previous day), slowly increasing $(>1-<10 \%$ higher than previous day), and rapidly increasing ( $\geq 10 \%$ higher than previous day).

Travel speed (mi/d) for individually PIT-tagged fish from reach-specific survival tests was calculated from the river mile of release to Three Mile Falls Dam (RM 3.7) for all detected salmonids. Correlations between travel speed and various river flow parameters were then determined using SAS and Excel. We used daily river flow data in 15-min intervals from all gauging stations near and below the release point to estimate the mean flow and mean delta flow (maximum minus minimum flow) for the river corridor during the travel period. Delta flows provided information on the maximum range of flow encountered within the river corridor (Berggren and Filardo 1993).

\section{Resident Fish and Predators}

All resident fish captured during the sampling season were identified and their presence noted. We counted northern pikeminnow (Ptychocheilus oregonensis) and bass (Micropterus spp.) at each trap check and measured their fork lengths $(\mathrm{mm})$. All other species were noted but not enumerated.

Avian predators were noted at both trap sites on an intermittent basis. We recorded species and number of each avian predator and the date and time observed. Dividing the number of observed predators by the number of times observations were made standardized the number of avian predators observed per day. We plotted the number of gulls observed with river flow $\left(\mathrm{ft}^{3} / \mathrm{s}\right)$ above Three Mile Falls Dam and with the number of fish detected over time.

\section{Statistical Analyses}

We used linear correlation (Pearson Correlation) to examine relationships between environmental variables and fish detection data, and canal diversion rate and fish collection efficiencies.

We used the $\mathrm{Chi}^{2}$ test of independence to determine significant differences between daily trap efficiencies and the $\mathrm{Chi}^{2}$ goodness of fit test to determine the proportional fit between temperature and flow regimes and fish migration. Differences in the proportion of PIT-tagged production fish detected were tested with the Binomial test (Snedecor and Cochran 1989). We 
used analysis of variance (ANOVA) and Duncan's multiple range test to test estimated total survival or minimum survival among reach sites. Proportional data was arc-sine transformed. We used SAS (Statistical Analysis Systems) for personal computers (SAS Institute 1990), MS Excel, and hand calculations to conduct our analyses. All tests were performed at a significance level of alpha $=0.05$.

\section{RESULTS}

\section{Outmigration Monitoring}

\section{PIT-Tag Operations}

The new $134 \mathrm{kHz}$ remote interrogation system, including the Minimon interrogation software, worked well throughout the season. Most problems were associated with the computer system (unintended shut down) and readers (over heating). Various beta versions of the Minimon program were also installed as the program was continually updated. Early on when the computer would shut down some tag codes were lost; programming the readers to store codes in the event of a computer shutdown resolved the lost tag code problem. Over heating of readers developed by late spring and was a probable result of continual operation and warm ambient temperature. One reader required servicing and repair by June.

We conducted detection efficiency tests for the remote interrogation system from 17 March to 25 June (Appendix Table A-1). The pipe was usually charged with water from $25-100 \%$ full during tests. Overall mean daily efficiency was $110 \%$. Therefore, we considered the interrogation system to be $100 \%$ efficient (duplicate tags were accounted for). At times, high reading-range efficiency resulted in fish being detected that were upstream of and not transiting through the detection system completely. These fish later passed into the sample tank and were subsequently double interrogated.

Number of interrogation, monitor, trap efficiency, and tagging files created are listed in Table 1. Tagging files at the trap mostly represent natural fish tagged for CTUIR monitoring. We periodically interrogated the PTAGIS database to retrieve tag data; more frequent database checking was required for timely assessment of trap efficiency results. Most PTAGIS reports were finalized by January 2001. Twenty-eight codes were orphaned (no associated file) which prevented timely and complete analysis. Later investigation revealed these codes were from four trap efficiency releases and six reach survival test releases (steelhead). Production files accounted for the remaining orphaned codes.

From $98-99 \%$ of detected fish (natural and hatchery) were interrogated through the remote detection system at West Extension Canal (Table 2). No tagged fish were detected at the rotary trap and sampled fish at Westland Canal were not scanned. Detections were fewest in March (2\% average) and greatest in April (16\% average) for both spring and fall chinook salmon

releases (Table 2). Rearing hatchery for spring chinook salmon was an important factor in relative detection of April-released fish but not for March-released fish. Tagged subyearling fall chinook salmon released in late May were detected the most, averaging 33\% detection, with each 
density rearing group detected similarly. Tagged production groups of summer steelhead averaged 11\% detection; however, large-grade steelhead released at Minthorn (RM 64.5) were detected more than large-grade steelhead released at Bonifer (RM 79) and small-grade steelhead released at Minthorn.

Of tagged natural species, chinook salmon were detected the least and summer steelhead detected the most (Table 3). Most detections of summer steelhead were from fish tagged and released in the mainstem Umatilla River and in Squaw Creek. Steelhead tagged and released in tributaries were detected least. This was the first year of tagging for natural coho salmon. Similar to steelhead, most detections of coho salmon were from fish tagged and released in the mainstem Umatilla River and Squaw Creek, with fish tagged in tributary systems detected least.

PIT-tag recoveries from islands in the mainstem Columbia River where bird colonies exist ranged from $1.2 \%$ to $3.4 \%$ of the species groups tagged for reach-specific survival tests (Table 4). Large-grade steelhead released in April suffered the highest mortality; $59 \%$ of the island mortality was from the East Sand Island rookery (RM 5) and 16\% was from the Three Mile Island rookery (RM 256). Most spring chinook and subyearling fall chinook salmon mortality was also attributed to the East Sand Island rookery ( $82 \%$ and $77 \%$, respectively). Fish were preyed on by birds throughout the mainstem corridor; upriver recoveries extended 52 miles above the confluence of the Umatilla and Columbia rivers.

\section{Trap Efficiencies}

We tagged 433 hatchery spring chinook salmon, 493 hatchery fall chinook salmon, 100 hatchery chinook salmon of unknown race, 419 hatchery subyearling fall chinook salmon, and 483 hatchery summer steelhead for trap efficiency tests (Table 5). We also tagged 209 natural chinook salmon and 100 natural summer steelhead. Percent survival and tag retention during the holding period was greater than $90 \%$ for most tests (Table 5). Warm water temperatures in late June caused the highest mortality during holding (15\%, natural chinook salmon).

Significant differences were found among daily trap efficiency estimates for all groups resulting in subpooling of the data (Table 6). Mean pooled estimates of trap efficiency ranged between $17.6-32.9 \%$ for hatchery fish and $25.8-32.6 \%$ for natural fish.

Eight releases were made of hatchery spring chinook salmon from mid-March to early May (Table 6). The first release (12 March) consisted of hatchery chinook salmon of unidentified race. Two releases made in March and early April produced no detections. Fish were detected from within $1 \mathrm{~d}$ up to $18 \mathrm{~d}$ after release, though most fish were detected within $2 \mathrm{~d}$. Mean travel time from release to detection was longest for the first few releases made in March and early April ( $>10 \mathrm{~d})$. Mean travel time decreased steadily from mid-April to the last release in early $\operatorname{May}(<1 \mathrm{~d})$.

Nine releases were made of hatchery fall chinook salmon from mid-March to mid-May (Table 6). The first release (12 March) consisted of hatchery chinook salmon of unidentified race. Fish were detected from within $1 \mathrm{~d}$ up to $30 \mathrm{~d}$ after release; most fish were detected within 
$2 \mathrm{~d}$ of release. Mean travel times were generally longest for fish released before mid-April, with travel times steadily decreasing beyond the 11 April release. All fish released in May were detected within $1 \mathrm{~d}$ of release.

Six releases were made of hatchery subyearling fall chinook salmon from late May to midJune (Table 6). Released fish were detected within $3 \mathrm{~d}$, with most fish detected within the same day of release. Fish from all releases had mean travel times of less than $1 \mathrm{~d}$.

Nine releases of hatchery summer steelhead were made between early April and early June (Table 6). Fish were detected from within $1 \mathrm{~d}$ up to $31 \mathrm{~d}$ after release; most fish were detected within the first day or two after release. Mean travel times were variable throughout the release period, ranging from $2 \mathrm{~d}$ in early April to $4 \mathrm{~d}$ in late May to $1 \mathrm{~d}$ in early June.

Three releases were made of natural chinook salmon from late June to early July (Table 6). Fish were detected from within $1 \mathrm{~d}$ up to $5 \mathrm{~d}$ after release, though most detections were within the first day or two after release. Mean travel times were all under $2 \mathrm{~d}$.

Two releases were made of natural summer steelhead in mid-May (Table 6). All fish but one (12 d) from both releases were detected within a few days after release. Mean travel times were near $1 \mathrm{~d}$.

\section{Collection}

We monitored the outmigration of juvenile salmonids from 1 October 1999 through 6 March 2000 at the rotary-screw trap (RM 1.2), though the trap did not operate from 15 - 16 February (15 hours) due to high river flow. We collected 196 fish at the rotary trap, which expanded to 199 fish when adjusted for unsampled time (i.e., while the trap was being checked) during the sampling period (Table 7). Most fish collected $(\mathrm{N}=189)$ were hatchery summer steelhead grade-outs (43.9 fish/lb) from the 29 November release at RM 2. These fish were first captured the day following release and continued entering the trap through 16 December. Capture peaked $(\mathrm{N}=108)$ on 1 December. Natural chinook salmon were captured from 21 December through 15 February, and natural summer steelhead were captured from 29 November through 6 January. No adult salmonids were captured.

We monitored at West Extension Canal (RM 3.7) from 6 March through 3 October 2000. (Results immediately following correspond to data collected up to 30 September, the end of the 1999-2000 contract period). On average, we sampled $13.5 \mathrm{~h} / \mathrm{d}$ for a total of 2,798 hours, or $56 \%$ of the monitoring period. We began $24 \mathrm{~h}$ sampling at $100 \%$ on 27 June and continued through the end of the season. We sampled 34,800 hatchery and natural salmonids within the specified sampling hours, which adjusted to a total of 109,529 fish when expanded by sample rate (Table 7). Sixty-six percent of the expanded sample numbers were hatchery salmonids (72,280 fish), $28 \%$ were coho salmon of unknown race $(31,131$ fish), and $6 \%$ were natural salmonids $(6,118$ fish). Of the expanded numbers for hatchery fish, $11 \%$ were chinook salmon of unknown origin, $34 \%$ were yearling spring chinook salmon, 39\% were yearling fall chinook salmon, 10\% were subyearling fall chinook salmon, $3 \%$ were coho salmon (AD-fin clipped), and $4 \%$ were summer 
steelhead. Of the expanded natural salmonids, $76 \%$ were chinook salmon and $24 \%$ were summer steelhead. No adult salmonids were captured.

Hatchery spring and fall chinook salmon dominated the collection through early May, with the highest concentrations following a release (Figure 6). Two mini-jack spring chinook salmon were captured in early July ( 216 and $245 \mathrm{~mm} \mathrm{FL}$ ), and an additional five mini-jacks (race unknown) were captured in late September (182 - $220 \mathrm{~mm}$ FL). Subyearling fall chinook salmon dominated samples for seven weeks following their release in late May. A portion of hatchery summer steelhead was collected in early April corresponding with first releases, though most were collected in mid-May.

Natural chinook salmon were captured during March, again in late May, and continuing through the end of the season (Figure 6). Unknown coho salmon (unclipped) were collected in large numbers immediately following the hatchery coho release in mid-March; collection decreased by mid-June. Natural summer steelhead were collected through July, peaking ( $\mathrm{N}=$ 135) with hatchery summer steelhead in mid-May.

Collection from 30 September through 3 October (beginning of 2000-2001 contract period) included one hatchery chinook salmon mini-jack, 17 natural chinook salmon, 2 natural coho salmon, and one natural summer steelhead.

A total of 177 scale samples were collected from juvenile salmonids from March to September 2000 for analysis by Tribal biologists (Table 8). Sixty percent of the scales collected were from smolted natural summer steelhead; $32 \%$ of collected scales were taken from unknown coho salmon to determine origin.

\section{Migration Parameters}

Production Fish: Tagged hatchery spring chinook salmon from Umatilla Hatchery were detected from 1 to $2 \mathrm{~d}$ after being force released (9 March); an earlier detection on 8 March was from a 6 March volitional release (Table 9; Figure 7). March-released fish from Little White Salmon Hatchery were not detected until 10 April. Final detection for all March release groups was in late April, with no discernable peak in detection. In April, spring chinook salmon reared at Little White Salmon Hatchery were detected $2 \mathrm{~d}$ after a forced release (12 April); Carson spring chinook were detected $4 \mathrm{~d}$ after the volitional release (6 April). For both groups, detection peaked in late April and last detection was in early to mid-May (Table 9; Figure 7). Detection duration and travel speed was shorter and faster respectively for April-released fish than Marchreleased fish (Table 9).

Fall chinook salmon reared at Bonneville Hatchery and released in early March and midApril exhibited similar migration patterns as spring chinook salmon (Table 9; Figure 8). First detections were $3 \mathrm{~d}$ from date of forced release in March and $5 \mathrm{~d}$ from date of volitional release in April; last detections were in mid-April (March release) and early May (April release). No peak detection was discernable for March-released fish; April-released fish peaked in late April 
and early May. Detection duration and travel speed was shorter and faster respectively for Aprilreleased fish than March-released fish (Table 9).

Tagged subyearling fall chinook salmon force released in late May (no volitional release) were detected within 1-2 d after release (Table 9; Figure 8); detection peaked within $2 \mathrm{~d}$. A small pulse of fish was also evident in early June following a rainstorm. Duration of detection was short, lasting an average of $16 \mathrm{~d}$. Travel speed was greatest for this group of fish, exceeding speeds of other production groups by 10 fold. Median travel speed was also faster for fish released at the uppermost acclimation facility (RM 74) than for fish released 18 miles lower. A tagged experimental group (non-acclimated) exhibited similar migration characteristics as tagged production fish (Table 9; Figure 8).

Large-grade and small-grade hatchery summer steelhead exhibited slightly different migration patterns between each other. Large-grade fish volitionally released at Bonifer (RM 79) in early April and force released $9 \mathrm{~d}$ later were first detected $4 \mathrm{~d}$ after the forced release date and last detected in early June at their peak (Table 9; Figure 9). Large-grade steelhead volitionally released lower in the river at Minthorn (RM 65) in late March and force released $6 \mathrm{~d}$ later were first detected $2 \mathrm{~d}$ after the forced release date and last detected in late May. Peak detection for these groups was in late May, nearly $1 \frac{1}{2}$ mos after their release (Table 9).

Detection duration and travel speed were similar for the two large-grade release groups. Smallgrade steelhead released at Minthorn in late April were first detected 1 wk after forced release and last detected in mid-June (Table 9; Figure 9). Dates of peak detection were the same as large-grade steelhead. Detection duration was slightly shorter and travel speed slightly faster than large-grade steelhead (Table 9).

An experimental group of tagged small-grade steelhead force released at Minthorn in early April was first detected $4 \mathrm{~d}$ later, whereas small-grade steelhead force released at Bonifer in midApril were first detected almost 1 mo later (Table 9; Figure 9). Last detection was in early June (Minthorn) and mid-June (Bonifer). Date of peak detection was similar to production release groups. Although travel speed was similar between the two experimental groups, detection duration was longer for the group released at Minthorn (Table 9). Median travel speeds were also identical to the large-grade groups they were released with.

Reach Survival Fish: Hatchery spring chinook salmon tagged for reach-survival tests were direct released from 7 -9 March. Fish from the Steelhead Park and Echo (RMs 9 and 27) test groups were initially detected at West Extension Canal $1 \mathrm{~d}$ after release; whereas, fish released at RM 80 were first detected $2 \mathrm{~d}$ after release (Table 9). With replicate releases combined, detection peaked on 9 March. Lower river releases were last detected within a week after release. Fish released at the uppermost site required nearly $3 \mathrm{wks}$ for last detection. Travel speed increased significantly with upper releases $\left(P=0.055 ; \mathrm{Chi}^{2}\right)$. Median travel time to John Day Dam was 33-37 d from dates of release at all sites (Appendix Table A-2).

Hatchery subyearling fall chinook salmon tagged for reach survival tests were direct released from 23-25 May. Lower river releases at RMs 9 and 27 were first detected the same day or the day after release (Table 9). Upper river releases at RMs 56 and 73.5 were first detected from 2 to $7 \mathrm{~d}$ after release. Detections peaked within $1 \mathrm{~d}$ of first detection for lower 
sites, and up to $3 \mathrm{~d}$ after first detection for upper sites. Dates of median and peak detection were similar. Travel speed generally increased with upper releases, though not significantly. Median travel time (days) to the lower Umatilla River was progressively longer with upper river releases, but travel time to John Day Dam was near $14 \mathrm{~d}$ for most all release groups, including the group released at RM 0 (Appendix Table A-2).

Large-grade summer steelhead tagged for reach-survival tests were released from $10-12$ April. Fish from the Steelhead Park (RM 9) release were first detected on the day of release (Table 9). Fish from the Echo and Rieth releases (RMs 27 and 48) were first detected $1 \mathrm{~d}$ after release, and fish from releases at upper acclimation sites (RMs 64 and 79) were first detected 4 $13 \mathrm{~d}$ after release. Last detections varied from 1 mo (lowest release site) to nearly 6 wks (upper release sites) after releases. Duration of detection was not significantly different among sites. Travel speeds appeared slowest for fish released at RM 27, fastest for fish released at RM 9, and similar for fish released at RMs 48, 64, and 79. Median travel time (d) to RM 3.7 was substantially shorter for fish released at RM 9 (1.5 d) when compared to fish travel times from upper releases (20.68 - 33.62 d; Appendix Table A-2). Although detections were low, travel time to John Day Dam varied by $10 \mathrm{~d}$ among all releases (17.3 - $27.5 \mathrm{~d}$; Appendix Table A-2).

Natural Fish: Tagging of natural fish by CTUIR began in late November 1999 and continued to mid-May 2000 (Table 9). Tagged in mid-December, only one natural spring chinook salmon was detected 5 mo later. No natural subyearling chinook salmon were tagged by CTUIR. Coho salmon tagged mostly in December, April, and May were detected mostly in May (Table 9; Figure 10). Coho salmon from the McKay Creek and Umatilla River tagging sites maintained the longest migration; detections ceased for tagged coho in early June. Summer steelhead tagged mostly in April and May were detected mostly in May, with peak detection in late May (Table 9; Figure 10). Steelhead from the Squaw Creek and Umatilla River tagging sites maintained the longest migration; detections ceased for tagged steelhead by early June (Figure 10). Fish from different tributary systems migrated out sporadically at different times with Birch Creek steelhead leaving the latest. Travel speed for both coho salmon and summer steelhead was fastest for fish tagged in the Umatilla River (Table 9).

Diel Movement: Most tagged hatchery and natural salmonids passed West Extension Canal between sunrise and sunset, with some exceptions (Figures 11 and 12). In March, the 7 tagged spring chinook salmon moved before sunrise and after sunset (Figure 11). In April and May, peak detection of spring chinook salmon was in early to mid-afternoon, with some movement in the morning in May.

Too few fall chinook salmon were detected in March to ascertain diel movement. In April, movement was primarily from early to late afternoon (1300 - 1700 hours; Figure 11). In May, most movement was again from early to late afternoon, but also at sunrise. In both months, few fish moved during darkness and in the morning hours. Diel movement of subyearling fall chinook salmon was similar in May and June, with fish migrating mostly between sunrise and sunset (Figure 11).

Tagged hatchery steelhead moved throughout the day. However, most movement in April was from 1300 - 1700 hours, whereas May movement was primarily between sunrise and sunset 
(Figure 12). Natural summer steelhead movement was similar to their hatchery counterparts, although it appeared movement shifted later in the day from April to June (Figure 12). Diel movement of tagged natural coho in April is represented by few fish so the pattern may be nonrepresentative (Figure 12). May movement was between sunrise and sunset, peaking near 1400 hours. In June, fish did not appear to move from shortly after sunrise to mid-afternoon; most movement was during darkness.

\section{Lengths}

Length frequency distributions of natural and hatchery juvenile salmonids are presented by month in Figures 13 - 15; other length data is presented in Appendix Table A-3. Uniform modal distributions are evident for hatchery spring chinook salmon (135 - $144 \mathrm{~mm}$ FL) and undifferentiated (unknown) chinook salmon (145 mm FL) from March to April (Figure 13). In May, modal fork length for spring chinook salmon shifted to $150 \mathrm{~mm}$ FL. Not shown are the several mini-jack spring chinook salmon (216 - $245 \mathrm{~mm} \mathrm{FL)} \mathrm{collected} \mathrm{in} \mathrm{July} \mathrm{and} \mathrm{the} \mathrm{unknown}$ race mini-jacks collected in September (5; 182 - $220 \mathrm{~mm}$ FL). Larger fall chinook salmon were more apparent in March (160 mm FL) and smaller fish were more common in May (140 - 149 $\mathrm{mm}$ FL).

Subyearling fall chinook salmon showed similar distributions in May and June, with modal fork length near $95 \mathrm{~mm}$ (Figure 14). In July, the distribution became bimodal with peaks at 85 $\mathrm{mm}$ and $105 \mathrm{~mm}$ FL, with some fish reaching $140 \mathrm{~mm}$ FL (possibly yearlings).

Marked (AD-fin clipped) coho salmon were mostly between 115 - 165 mm FL (Figure 14). Length of measured fish appeared to increase from March to May. One $221 \mathrm{~mm}$ FL coho salmon was collected in May.

Most hatchery summer steelhead were generally between 205 - $239 \mathrm{~mm}$ FL between April and June (Figure 14). A number of smaller-sized steelhead (135 - $152 \mathrm{~mm} \mathrm{FL)} \mathrm{were} \mathrm{collected} \mathrm{in}$ mid-May. In July, two fish (205 and 219 mm FL) were collected.

The breakout between natural yearling and subyearling spring chinook salmon is apparent between April and May (Figure 15). In April, most spring chinook salmon were near $120 \mathrm{~mm}$ FL. In May, more smaller-sized chinook salmon between $60-105 \mathrm{~mm}$ FL were collected, representing the subyearling life stage. Fry-sized chinook salmon $(<50 \mathrm{~mm})$ were collected as early as March and as late as June. By June and July, most natural chinook salmon were between 65 - $95 \mathrm{~mm}$ FL, representing both spring and fall chinook subyearlings. Considerable growth of subyearling chinook salmon was evident by August and September (120 mm modal FL).

Length distribution of natural summer steelhead was highly variable in March, ranging from 144 - 256 mm FL (Figure 15). In April, most fish were between 165 - 185 mm FL, with three fish greater than $300 \mathrm{~mm}$ FL. In May, most steelhead measured between $175-205 \mathrm{~mm}$ FL. In June, several steelhead parr (69 $\mathrm{mm}$ and $74 \mathrm{~mm} \mathrm{FL)} \mathrm{were} \mathrm{collected,} \mathrm{though} \mathrm{most} \mathrm{were} \mathrm{between}$ 
$165-215 \mathrm{~mm}$ FL; one fish measured $257 \mathrm{~mm}$ FL in June. Three steelhead were collected in July at $239 \mathrm{~mm}, 240 \mathrm{~mm}$, and $251 \mathrm{~mm}$ FL.

Unmarked coho salmon represent fish of both hatchery and natural origin (Figure 15). The length-frequency distributions for March, April, and May represent the yearling life stage of unmarked coho salmon. The lower end of the length-frequency distribution mostly represents natural fish (subyearlings) migrating out in June, whereas the upper end in June probably includes hatchery fish. Natural subyearling coho salmon were primarily between $65-80 \mathrm{~mm}$ FL in June.

\section{Fish Condition and Health}

We examined between 700 and 1,800 hatchery fish for injuries, disease, and scale loss at West Extension Canal (Tables 10 and 11). Bird marks represented $68 \%$ of the injuries, comprising $2-7 \%$ of all fish examined per species (Table 10). Both coho salmon and summer steelhead exhibited the greatest percentage of bird marks. Other types of injuries present included damage to eyes, head, operculum, or body, torn caudal fins, and fungus. Other injuries were less extensive than bird marks, representing from near $1-2.3 \%$ of all fish examined, with injury to the caudal fin most common. Bird marks were commonly associated with fungus, injury to the body, and mortality. Steelhead exhibited most injuries overall. External parasites included leeches and the metacercaria from black spot disease (Neascus metacercariae), which were present on $<1 \%$ of hatchery fish. None of the fish examined exhibited signs of BKD (bacterial kidney disease).

Scale loss on hatchery fish was minimal $(<15 \%)$ for most species, except summer steelhead and coho salmon (Table 11). Nearly $34 \%$ of the steelhead and $25 \%$ of the coho salmon were partially descaled and descaled. Excessive scale loss for all species was commonly attributed to attacks by birds and caudal tail injury. Condition was poorest during the migration peak for each species. In-river mortality and handling or trap-caused mortality was low $(<0.1 \%)$ for all species.

Of natural or unmarked fish collected at both sampling sites, we examined between 600 and 3,600 fish (Table 10). Unmarked coho salmon (natural and hatchery) were included in this category. Bird marks represented nearly $50 \%$ of the injuries incurred by natural fish, comprising $0.7 \%$ to nearly $5 \%$ (steelhead and coho salmon) of all fish examined by species. Injury to the caudal fin was the most common injury. Natural chinook salmon and summer steelhead were commonly infested with black spot disease.

Scale loss on natural fish was minimal $(\leq 16 \%$; Table 11$)$. Summer steelhead and coho salmon exhibited the greatest degree of scale loss, which was associated with bird attacks and caudal injury. Natural mortality was $0.2 \%$ or less; trap-caused mortality was highest for natural steelhead $(2.1 \%)$.

We submitted 30 natural chinook salmon, 2 natural coho salmon, 33 natural summer steelhead, and 1 hatchery steelhead to ODFW pathology for disease examination. All fish were 
collected dead or they died at West Extension Canal. ELISA analysis (for Rs antigen for BKD) indicated most fish were $<0.15$ OD (low level positive). One natural steelhead and two natural chinook salmon had OD levels at or $>0.23$ (moderately positive). A random selection of six fish $(\mathrm{NCOH}, \mathrm{NSTS}, \mathrm{NCH})$ tested negative for viruses. No disease causing bacteria were detected within cultures on three natural chinook salmon. Only black spot disease was apparent.

\section{Lamprey Monitoring}

Pacific lampreys collected from October 1999 to March 2000 at the rotary-screw trap (RM 1.2) were all juveniles (68 - $191 \mathrm{~mm}$ TL; Figure 16). Of the 496 juvenile lampreys captured, 133 were macrophthalmia (149 mm mean TL) and 363 were larvae (154 mm mean TL, $\mathrm{N}=$ 360). Macrophthalmia were captured late November through early March, with the peak in December $(\mathrm{N}=95$; Figure 17). Larval lampreys were captured from late October through early March, with most captured in February $(\mathrm{N}=270)$. Captures of macrophthalmia and larval lampreys were positively correlated with river flow $(\mathrm{r}=0.281, P=0.001, \mathrm{~N}=131$ and $\mathrm{r}=0.203$, $P=0.020, \mathrm{~N}=131$, respectively; Figure 17$)$. One adult lamprey $(350 \mathrm{~mm})$ was captured on 18 June at West Extension Canal.

Trap efficiency tests were conducted with Pacific lampreys at the rotary-screw trap from November 1999 through February 2000 (Table 12). Eleven releases were made with release groups consisting of one to 67 macrophthalmia. A total of 129 macrophthalmia were released for trap efficiency tests. Only one lamprey was recaptured (28 December). A rough estimate of 17,157 metamorphosed lamprey migrated out of the lower river (Appendix Table A-4).

\section{Abundance and Survival}

\section{Migrant Abundance and Survival}

Abundance and survival estimates were determined for tagged natural and hatchery juvenile salmonids detected at West Extension Canal (Tables 13 and 14). Hatchery fish were from various rearing hatcheries and released at various times (Table 13). All groups were volitionally released for one week then force released. Natural fish were tagged and released at various upper Umatilla River and tributary locations (Table 14).

March production releases of spring chinook salmon from Umatilla Hatchery were split between two different rearing ponds and two different acclimation strategies. Acclimated similarly at RM 80 for $30 \mathrm{~d}$ prior to release, mean survival of fish from super-oxygenated Michigan ponds (M1A-M1C; 22.4\%) was 10 percentage points better than standard-reared fish (O5A and O5B; 12.9\%), primarily due to higher survival of fish from M1A (Table 13). In addition, mean survival of fish acclimated over winter at RM 80 (ponds O4A and O4B; 42.6\%) was greatly improved from the standard acclimation strategy of the 5A and 5B series. However, due to high variability from small trap efficiency estimates, confidence intervals were extremely wide for March releases. Overall survival of Umatilla Hatchery spring chinook salmon was $25.0 \%( \pm 19.3 \%)$. 
Fish reared at Little White Salmon Hatchery and released in March were similarly detected and had a similar survival estimate as most tag groups from Umatilla Hatchery receiving standard acclimation (Table 13). However, survival of spring chinook salmon reared at Little White Salmon and released in April was most similar to the improved survival of cold-water acclimated fish released in March (Table 13). April-released spring chinook salmon from Carson Hatchery survived best (Table 13). Overall survival of all spring chinook salmon release groups combined was $34.7 \%$ ( $\pm 14.1 \%$; Table 13$)$. Binomial testing for significant differences between groups was not possible due to insufficient detection numbers in the lower river.

Detection and survival was lower for March-released yearling fall chinook salmon reared at Bonneville Hatchery than April-released fish (Table 13). Overall, 41.2\% of the tagged fish from these two release groups survived to the lower Umatilla River $( \pm 12.9 \%)$.

Survival estimates for tagged subyearling fall chinook salmon reared at Umatilla Hatchery and acclimated and released at RM 73 ranged from 59.4-76.3\% (Table 13). Survival of A-pass fish $(68.8 \% \pm 10.9 \%)$ was similar to survival of B-pass fish $(67.8 \% \pm 10.9 \%)$; detections were not significantly different with binomial testing $(P=0.758)$. Overall survival of the 6 fish groups released at RM 73 was $68.3 \%( \pm 7.7 \%)$. Survival estimates for the 3 groups of fish acclimated and released at RM 56 were lower than RM 73 estimates (Table 13) and detections were significantly different $(P<0.001)$. Overall survival for fish released at RM 56 was 57.1\% $( \pm 8.9 \%)$. Overall survival of tagged fish from all ponds and sites was $64.6 \%( \pm 5.9 \%)$.

Two groups of summer steelhead were released from Umatilla Hatchery. One group (larges) was released from late March to mid-April at the Bonifer (RM 79) and Minthorn (RM 65 ) acclimation sites. The second group (smalls) was released in late April at Minthorn. Of the two early releases, survival of the Minthorn release group was significantly higher $(76.4 \%, \mathrm{P}<$ 0.05; Table 13), although test results are weak due to insufficient detections from the Bonifer release group. Survival of small-grade steelhead released at Minthorn was similar to large-grade steelhead released at Bonifer. Overall survival of tagged steelhead was 56.4\% $( \pm 23.1 \%)$

Only one tagged natural spring chinook salmon was detected in the lower river from the upper-river tag site at RM 80 (Table 14). Most detected natural coho salmon were from the RM 80 tag site. Percent detection and survival progressively decreased with lower river tag sites. Fewest detections were from coho salmon tagged in McKay Creek. Overall percent detection of tagged natural coho salmon was $6.7 \%$ and estimated survival was $13.6 \%( \pm 3.5)$.

Percent detection and survival of natural summer steelhead was highest for steelhead tagged and released higher in the mainstem at RM 80 and at Minthorn (RM 64.5; Table 14). Fewest detections were from Buckaroo Creek and West Fork Birch Creek; no fish were detected from releases made in Moonshine or Cottonwood creeks. Overall percent detection of tagged natural steelhead was $10.4 \%$ and estimated survival was $60.0 \%( \pm 30.1 \%)$.

Abundance of natural fish sampled at the trap sites from January through September is presented in Table 15. Abundance of chinook salmon includes both races (spring and fall chinook) and age classes $(0+$ and $1+)$. Peak abundance in June mostly represents subyearling fall chinook salmon. July numbers in the lower river were reduced due to upriver transport 
operations. Total chinook salmon abundance was 46,764 fish, of which 15,055 were estimated to be mostly yearling spring chinook salmon and 31,709 were estimated to be subyearling spring and fall chinook salmon. Abundance of coho salmon (subyearlings) peaked in June as well. Total coho salmon abundance was 30,163 fish, comprised of yearling and subyearling age classes (ascertained in the field as natural, apart from an unmarked designation). Summer steelhead were most abundant in May, although substantial numbers migrated in April as well. All age classes of steelhead are represented, with a total abundance of 81,759 fish.

\section{Reach-Specific Survival}

Tag loss was highest for spring chinook salmon and lowest for subyearling fall chinook salmon during tagging for reach-survival tests (Table 16). Tagging mortality was also highest for spring chinook salmon due to cold-water disease affects (personal communication, J. Hurst, ODFW, Irrigon, OR). Only summer steelhead consumed tags. Of the 16 fish known to consume tags, 14 contained 2 tags each and 2 contained 4 tags each.

Replicate releases of tagged spring chinook salmon showed mean in-basin survival to be similar for releases at RM 80 and RM 27 and highest for fish released at RM 9 (Table 17). ANOVA testing with transformed data indicated no significant difference in survival among sites.

Tagged subyearling fall chinook salmon released at four river sites exhibited higher (and similar) survival for all sites below the uppermost release site at RM 74, although survival of fish from the RM 27 site was slightly depressed (Table 17). ANOVA testing with transformed data indicated no significant difference in survival among sites.

Large-grade summer steelhead released in mid-April exhibited similar survival from the two upper sites at Bonifer and Minthorn (42.4 - 49.4\%), and incrementally improved survival from RM 48 to RM 9 (Table 17). ANOVA testing with transformed data indicated significant differences in survival among sites $(P=0.036$; Table 17). Multiple comparison testing indicated releases at RMs 79, 65, and 48 were not significantly different from each other, but they were from the lowermost release site at RM 9. Survival of fish released at RM 27 was not significantly different from any other release sites.

A similar pattern emerged with mainstem Columbia River detections and all detections combined (Umatilla River and mainstem interrogation sites), with slight deviations within release groups (Table 18). For spring chinook salmon, percent total detection was significantly different between the RM 80 and RM 9 releases $(P=0.038)$. Mainstem detection of subyearling fall chinook salmon release groups was significantly higher for fish released at the mouth of the Umatilla River $(P=0.028)$. Percent detection of these fish was double the detection of fish released at RM 9. Total percent detection was not significantly different among subyearling release groups (excluding the RM 0 release, which was only detected on the mainstem). Total percent detection of summer steelhead was highest for the RM 27 and RM 9 release groups. As with in-river survival, ANOVA testing with transformed data indicated a significant difference in 
percent detection among sites $(P<0.001)$; releases at and above RM 48 were detected significantly less than releases lower in the river.

\section{Environmental Conditions and Bypass Operations}

\section{Environmental Conditions}

River flows at all main HYDROMET gauging stations during the project period are presented as stacked flows in Figure 18. Flows peaked during March and early April, reaching $2,573 \mathrm{ft}^{3} / \mathrm{s}$ at RM 2.1. Flows were also high in mid-December $\left(1,730 \mathrm{ft}^{3} / \mathrm{s}\right)$. Flows were lowest from October through late November and from July through September. Minimum flows of near $50 \mathrm{ft}^{3} / \mathrm{s}$ remained in the river corridor throughout the summer period.

Secchi depth (measured at RMs 1.2 and 3.7) was negatively correlated with river flow at RM $2.1(\mathrm{r}=-0.839, P=<0.001, \mathrm{~N}=222$; Figure 19$)$. Water clarity reached over $2.0 \mathrm{~m}$ during low flow periods and decreased to less than $0.5 \mathrm{~m}$ during peaks in flow. Water clarity was minimal just after the release of hatchery summer steelhead grade-outs in late November and when juvenile salmonids were migrating in March and April. Water clarity decreased greatly on 2 June following a brief rainstorm. Although most fish had emigrated by this time, a few late migrants remained.

Water temperatures in the lower Umatilla River ranged from a low of $39^{\circ} \mathrm{F}$ in January to a high of $73{ }^{\circ} \mathrm{F}$ in July and August (Figure 20; Appendix Table A-5; Appendix Table A-6). Although temperatures progressively increased throughout spring and into summer, slight decreases were observed when river flows increased. Mean water temperature (RMs 1.2 and 3.7) was negatively correlated with river flow at RM $2.1(\mathrm{r}=-0.457, P<0.001, \mathrm{~N}=298)$.

Natural Fish: Daily detections of natural salmonids were compared with mean river flow (RM 37.6), water temperature (RM 37.6) and Secchi depth (RM 3.7; Table 19; Figure 21).

Natural coho salmon detections were positively correlated to water temperature but not to flow or Secchi depth, although movement did appear to increase as flows decreased (Figure 21). Peak detection in early June was associated with a freshet rainstorm. When breaking the environmental parameters into discrete categories, natural coho salmon emigration was influenced by a negative change in river flow between days and by higher temperatures (Table 20). Rapidly decreasing flows (more than a $10 \%$ reduction from previous day) coincided with near $30 \%$ of coho detections even though this flow category only comprised $17 \%$ of the time. In addition, $50 \%$ of detections were recorded in the temperature range between 59 to $<63^{\circ} \mathrm{F}$, whereas temperatures were in this range only $24 \%$ of the detection period (Table 20 ).

Natural summer steelhead detections were negatively correlated with river flow (although a detection spike in early June was associated with summer freshet) and positively correlated with Secchi depth (Table 19; Figure 21). The correlation with temperature was near significant, plus detections appeared to increase as temperatures rose throughout the detection period (Figure 21). Accordingly, $67 \%$ of the detections were during lower flows $\left(<750 \mathrm{ft}^{3} / \mathrm{s} ; 50 \%\right.$ of detection period), and $75 \%$ of the fish were detected while flows were decreasing ( $64 \%$ of detection 
period; Table 20). A relationship between detections and temperature was revealed in $50 \%$ of detections being recorded at the higher end of the temperature range $\left(\geq 59^{\circ} \mathrm{F}\right)$, though these temperatures only existed during $33 \%$ of the detection period.

Production Fish: Daily detections of hatchery fish were compared with mean river flow (RM 37.6), water temperature (RM 37.6), and Secchi depth (RM 3.7; Table 19). Detections of yearling spring and fall chinook salmon were correlated with all three environmental variables negatively correlated with river flow and positively correlated with temperature and Secchi depth (Table 19; Figures 22 and 23). Detections of subyearling fall chinook salmon and large-grade summer steelhead were not correlated with environmental variables (Table 19). However, movement of subyearling fall chinook salmon was influenced by the rainstorm freshet in early June, which also decreased temperatures (Figure 23). Large-grade and most notably small-grade steelhead also responded to this stimulus with increased detections (Figure 24). In fact, detections of small-grade summer steelhead were positively correlated with river flow (Table 19).

Reach Survival Fish: Detections of fish from reach-specific survival tests were analyzed to determine relationships between fish travel speed and mean river flow, as well as delta river flow (maximum minus minimum flow; Table 21). Travel speeds of hatchery spring chinook salmon released at Imeques (RM 80) and subyearling fall chinook salmon released at Thornhollow (RM 74) and ODFW (RM 56) increased as river flows decreased in the migration corridor. Travel speeds of fish (both races) released in the mean lower river (RMs 27 and 9) were not correlated with river flow. Spring chinook salmon travel speeds were not correlated with delta flow at any release site. Subyearling fall chinook salmon travel speeds, however, decreased as the difference between the maximum and minimum flows increased for fish released at upriver sites (RMs 74 and 52); fish released at Echo (RM 27), though, had travel speeds that increased with an increasing delta flow. Travel speed of steelhead from all release sites was positively correlated with river flow and delta river flow.

\section{Bypass Operations}

Diversion of water at West Extension Canal varied throughout the season (Figure 25). At times, irrigators were reliant on Phase I exchange pumping as flow decreased in the lower river to near or below $250 \mathrm{ft}^{3} / \mathrm{s}$. Operations at West Extension Canal appeared to influence movement of various species of hatchery and natural juvenile salmonids through the bypass. In general, most yearling hatchery salmonids were detected at the canal facility from April through midMay when canal withdrawals were from 33 to $99 \mathrm{ft}^{3} / \mathrm{s}$. When Phase I pumping was first initiated on 22 May and diversion curtailed, detections of hatchery fish declined sharply for a brief period (Figure 25). Subyearling fall chinook salmon were released immediately following this change in bypass operations, and detections peaked shortly thereafter during Phase I pumping (with the river-return pipe open). A freshet in early June reduced the need for exchange pumping and allowed canal diversion to resume. During this brief period of diversion, another increase in detections was apparent (various species). Phase I pumping was reinitiated on 5 June and continued throughout the remainder of the season; fish detections had greatly diminished by this time. 
We compared efficiency estimates of the juvenile bypass facility trap with West Extension Canal diversion rates (Table 22). Trap efficiency estimates for hatchery fall chinook salmon and natural chinook salmon were positively correlated with diversion rate $(\mathrm{r}=0.735, P=0.038, \mathrm{~N}=$ 7 and $\mathrm{r}=1.000, P=0.008, \mathrm{~N}=3$, respectively). Hatchery spring and subyearling fall chinook salmon as well as hatchery and natural summer steelhead trap efficiencies had no correlation to diversion rate.

Water was released from McKay Reservoir at times throughout the season to aid fish passage (Figure 25; mid-summer releases were for irrigation purposes). The increase in released water during late May coincided with the movement and detection of hatchery subyearling fall chinook salmon. Although detections of juvenile fish had diminished when released water was increased in mid-June, collection of non-PIT tagged hatchery subyearling fall chinook and natural salmonids continued (Figure 6). As Phase I pumping declined and canal diversion was re-instated (1 July), juvenile fish transport at Westland Canal was initiated (7 July) to circumvent migration of late migrants during the resulting low river flows. Collection of natural salmonids declined the week following initiation of transport operations and remained low until midSeptember when natural flows began increasing (Figures 6 and 25).

\section{Resident Fish and Predators}

Resident fish species were collected at the rotary trap and West Extension Canal throughout the season (Table 23), but mostly prior to and after the major emigration period for juvenile salmonids. At the rotary trap, mostly dace, shiners, and suckers were captured from October to early March, but a fair number of bass and chiselmouth were also collected. These fish were primarily juvenile life stages. Eight large-sized northern pikeminnow $(130-255 \mathrm{~mm} \mathrm{FL})$ entered the trap, mostly in October and November.

At West Extension Canal, many more resident fish were captured (Table 23). Bass species were mostly sampled from May (136 mm mean FL) to September (168 mm mean FL). In July, several bass fry were also noted. Northern pikeminnow began increasing in samples beginning in July ( 8 fish; $170 \mathrm{~mm}$ mean FL). In September, 9 northern pikeminnow were sampled (202 mm mean FL). We also sampled large numbers of chiselmouth and suckers at the canal from June through September (Table 23).

Our continued sampling at the canal facility past the contract period (30 September) encountered hundreds (641) of northern pikeminnow between 29 September and 3 October (mean FL = $203 \mathrm{~mm}$; maximum $\mathrm{FL}=258 \mathrm{~mm}$ ). We also collected 737 suckers and 652 chiselmouth during that time (no lengths).

Eight species of avian predators were also observed at the trap sites (Table 24). Common mergansers (Mergus merganser) and belted kingfishers (Ceryle alcyon) were more commonly observed at the rotary trap. Most commonly observed birds at the canal site were cormorants (Phalacrocorax spp.) and gulls (Larus spp.). Observations of both bird species peaked in May. Less commonly sited were kingfishers, great blue herons (Ardea herodias), mergansers, 
American coots, (Fulica americana), night herons (Nycticorax nyctivorax), and osprey (Pandion haliaetus). Avian predators continued to be observed at Three Mile Falls Dam throughout the summer (Table 24).

Location of birds during observation at the canal trap included swimming in the dam forebay, flying at or below the dam, perched on the dam sill, at the canal outfall, in the canal headworks, and standing or swimming in the river below the dam (Table 24). At the rotary trap, most birds were observed flying. At the canal trap, most gulls and cormorants were observed swimming in the forebay. As flows decreased in May, these birds also commonly perched on the dam sill. Night herons were mostly observed at the bypass outfall and great blue herons preferred standing in the river below the dam. These locations appeared to be the preferred niches for feeding.

Gull observations coincided with the presence of juvenile salmonids during their outmigration (Figure 26). Highest gull activity coincided with periods of low river flow $(<500$ $\mathrm{ft}^{3} / \mathrm{s}$ ) and high salmonid abundance. Observations of gulls spiked greatly, particularly in late May, when subyearling fall chinook salmon were migrating.

\section{DISCUSSION}

\section{Outmigration Monitoring}

Remote interrogation of PIT-tagged fish in the lower Umatilla River continues to be an important methodology in this study. Detections have strengthened our results and the results of other projects. The upgraded 134-kHz transceiver system and the new Minimon interrogation program worked well. We see potential in future enhancements that would increase efficiency and effectiveness of the system. With the planned installation and operation of adult PIT-tag interrogation systems at mainstem Columbia River dams, there is promise for adult interrogation in the Umatilla River at Three Mile Falls Dam. Such a system would not only provide data to estimate smolt-to-adult survival based on tag returns, but detection of tagged juvenile migrants would be enhanced. This would provide information on fish behavior and route preference during all flow regimes and changes in passage facility operations.

With the second year of remote interrogation, trap efficiency estimates for all species continued to generally be greater than before remote detection capabilities. We believe this is due to the ability to fully detect and account for all tagged fish passing through the bypass facility (including the interrogation of sampled fish). This ability improves all estimates of detection, abundance, and survival. Trap efficiency tests continue to be of critical importance in estimating abundance of juvenile migrants. This year, the inability to obtain sufficient numbers of yearling chinook in March for trap efficiency tests tempered the strength of our estimates. Confidence intervals, which are based on the Bootstrap method, become exceedingly wide when trap efficiency estimates are low. We plan to devise a means to sample fish at pre-determined times that would allow collection when fish are moving through and when the facility is unattended. 
One drawback with the use of PIT tags, however, is the recommended protocol not to tag fish when water temperatures exceed $17^{\circ} \mathrm{C}$. In June, temperature of the Umatilla River commonly exceeds this threshold, which restricts our ability to tag fish for trap efficiency tests. Natural chinook salmon began migrating in large numbers in late June and early July, a time when the Umatilla River was nearing its highest temperatures (Figure 20). The few tests conducted at high temperatures resulted in increased tagging mortalities.

Provision of lower river flows $\left(50 \mathrm{ft}^{3} / \mathrm{s}\right)$ throughout summer allowed the canal facility to operate and full sampling to continue. This ability to sample migrants from July through September, when monitoring is normally impossible, provided interesting data on late season migrants.

The late season collection of larger-sized chinook salmon this year is consistent with the capture of four mini-jacks in July 1999 (Ehlers et al. 2001). In 2000, spring chinook salmon mini-jacks began appearing at the east-bank fish ladder on 26 June (CTUIR and ODFW 2000). Fish captured at the canal trap in July were determined to be spring chinook salmon mini-jacks, classified through coded-wire tag analysis as being hatchery fish between 220 and $295 \mathrm{~mm}$ FL (personal communication, W. Stonecypher, ODFW, Hermiston, OR). We also collected five large chinook salmon in September (182 - $220 \mathrm{~mm}$ FL). Because hatchery fall chinook salmon mini-jacks are classified as fall-captured fish $>300 \mathrm{~mm}$ FL, these fish may have been late juvenile migrants, although two of the fish were sexually mature. The advent of mini-jacks returning the same year they were released is a mystery and a concern. The trigger for a mini-jack life history for hatchery fish is still unknown. The presence of these fish, especially in large numbers, also has unknown repercussions for the spawning population.

We also collected natural subyearling chinook migrants well into September, which had not been possible in years past. The summer-long presence of these fish indicates that summer flows are indeed necessary for juvenile migrants. When the Umatilla Basin Project was developed, the general belief was that summer flows were not necessary because of the assumed absence of salmonids during that period (USBR and BPA 1989; Boyce 1986). Monitoring has demonstrated that flows are necessary year round to fully allow the expression of all life histories of all species and races of salmonids. If natural production of all species is the desired goal of the Fisheries Restoration Program, then managers and co-managers should strive to ensure yearround flow is provided. We recommend the continued release of McKay storage water for fish and the continued operation of Phase I pumping during the typical summer "dry-up" period.

Lamprey restoration in the Umatilla River is a recent goal of CTUIR. Our monitoring of juvenile lampreys in the Umatilla River addresses a critical uncertainty identified by the Columbia Basin Pacific Lamprey Technical Work Group (1999) in that migration timing and juvenile abundance can be determined. In general, numbers of juvenile lamprey captures in the Umatilla River have been on an upward trend since the initiation of flow enhancement in 1995 
(Appendix Table A-4). In 2001, a substantial number of juvenile lampreys were collected (< 2,500) at the rotary trap (Knapp et al. In Preparation).

It is possible that flow enhancement measures have improved migratory, spawning, and rearing conditions for Pacific lamprey, as well as salmonids. 1997 was the first year of continued flow in the lower river through June, primarily to improve passage conditions for subyearling fall chinook salmon. Although adult migrations in large numbers have eluded observation at passage facilities at Three Mile Falls Dam (personal communication, D. Close, CTUIR, Mission, OR), we assume that higher juvenile captures are a result of increased adult spawners. The Confederated Tribes of the Umatilla Indian Reservation's Lamprey Restoration Plan (Close In Preparation) includes a strategy for the supplementation of in-basin lamprey populations. With this additional outplanting of adult lampreys, higher summer flows are a necessity for the success of a self-sustaining population. Augmenting summer flows through July and August would be of further benefit to adult migrants by improving migratory and spawning conditions.

Summer flow enhancement would possibly benefit juvenile lamprey as well. In Cedar Creek, a tributary to the Lewis River in the lower Columbia basin, sufficient flows are available to operate a rotary-screw trap nearly all year; juvenile lampreys are captured during all months of operation and are believed to migrate year-round (Stone et al. 2001; personal communication, J. Stone, USFWS, Vancouver, WA). Continuation and improvement of the current flow enhancement regime in the Umatilla River through the summer months might permit year-round emigration or movement through the lower river by juvenile lampreys, plus provide suitable habitat conditions for rearing. In July 2001, numerous juvenile lampreys were discovered dead below Three Mile Falls Dam when curtailed flows during high temperatures created intolerable rearing and passage conditions.

The delayed migration of large-grade steelhead released in early April may be associated with their smolt development, with environmental factors, or both. Since small-grade steelhead were released later but peaked at the same time as large-grade fish (late May), the small-grade fish may have been more smolted. Our studies in 1995 (Knapp et al. 1996) and 1996 (Knapp et al. 1998a) indicated that smolt development coincided with migration timing in that peak emigration was comprised of mostly smolted fish. Managers should consider release timing to be as important a strategy as release location. Later releases of steelhead larges lower in the river may be most optimal for increasing juvenile survival and ultimately smolt-to-adult survival for the benefit of harvest.

However, one goal of the steelhead program is to produce a hatchery product that is similar to natural populations and natural Umatilla River donor stock. Although migration peaks for hatchery and natural steelhead coincide, other aspects of their life history are dissimilar. For steelhead smalls, their lower survival and migration success compared to steelhead larges overall may be indicative of the tendency to over-winter and migrate out as age- 2 fish; this is the most common emigration age for natural steelhead (Knapp et al. 2000). Forcing these fish into a 1year smolt goes counter to the desired goal of mimicking natural life history patterns. The challenge for hatchery managers is to establish and maintain hatchery populations of steelhead with prescribed patterns of life history similar to the natural spawning population with which 
they may interbreed. The Umatilla Hatchery steelhead program has struggled to align itself with this particular goal.

Condition of hatchery steelhead continues to be the poorest among hatchery species, and natural steelhead were also in poor condition. Based on the degree of bird marks, it is apparent that birds have a great impact on fish condition and may also be a major cause of mortality. Steelhead and coho salmon incurred the most bird marks, possibly due to prolonged residency in the river or being more visible and vulnerable due to their larger size, particularly steelhead. In addition, the migration peak for this species coincides with the release of subyearling fall chinook salmon, which tends to attract avian predators in the lower river. Injury to the caudal tail may be a reflection of backwards orientation during downstream migration. Black spot disease continues to be prevalent among natural fish and some hatchery species. It appears that the longer a fish is in the river, the more prone it is to being infested with the disease parasite. In earlier studies (Knapp et al. 1996, 1998a), black spot disease was not present on hatchery species, indicating the present infestation of this parasite has expanded.

This year, survival of subyearling fall chinook salmon was affected by an outbreak of caudal-fin erosion and severe tail fungus at the acclimation ponds (Pathology Report of 5/19/00, ODFW Pathology Lab, La Grande, OR). The fungus problem started to develop 3-4 days after transfer to the acclimation sites at RMs 73.5 and 56 and mortality neared $1 \%$ at the height of the outbreak, with holding conditions (temperature) and mortality worse at the RM 56 site (Onjukka et al. 2002). We sampled few fish with tail fungus in the lower river, signifying that affected fish may have died en route. This was also the first year for use of the automated mass marking machine on subyearling fall chinook salmon. It is unclear whether this was a factor in the incidence of tail fungus.

\section{Abundance and Survival}

Based on migration parameters and survival estimates for the separate steelhead production release groups, the Bonifer release site in Meacham Creek continues to demonstrate poorest results. The best release strategy for large-grade summer steelhead appears to be a combined volitional and forced release from the Minthorn acclimation pond at RM 64.5. Using PIT-tagged fish, survival estimates for this group in 1999 (71.4\%; Appendix Table A-8) and in 2000 (76.4\%) were the highest of all release strategies. In years prior to PIT-tag use, this study consistently found that steelhead released at Bonifer traveled later and were recovered less than other release groups (Knapp et al. 1996, 1998a, 2000). Temperature may play a role in stimulating movement, as well as smolt development. We recommend that steelhead be released as low in the basin as practical to improve their survival.

Survival did not appear to be improved for small-grade steelhead when released at Minthorn in 2000 (52.4\%) compared to a Bonifer release in 1999 (55.6\%; Appendix Table A-8).

However, the Minthorn release strategy for this later release group will need to be continued to more fully determine its benefits. Survival estimates for combined steelhead releases from 1998 to 2000 are very similar (Appendix Table A-7), indicating steelhead survival may be at its maximum with current rearing and release strategies and river and environmental conditions. 
Since reach survival tests began in 1998, minimum survival of steelhead has been less for upper reaches than lower reaches (Appendix Table A-9). One possible explanation for this distinct survival difference may be the existence of a thermally-induced migration barrier, particularly between RM 48 and RM 27. At RM 27 and below, estimated survival within the basin was above $75 \%$ as these fish promptly moved out. A FLIR (forward-looking infrared radiometer) thermal profile of the river reaches in 1998 showed an abrupt elevation in river temperature near Westland Dam at RM 27 (CTUIR, unpublished data). This thermal transition may be a barrier to movement for fish upriver, and a migration trigger for fish below.

The survival estimate for spring chinook salmon in $2000(35 \%)$ was less than estimated survival in 1999 (48\%; Appendix Table A-7 and A-8). Survival continues to be less than optimal (> 80\%) for this group of fish. In both years, survival was less for March-released fish (regardless of rearing hatchery) than April-released fish. In addition, highest survival in 2000 was for Carson-reared fish released in April; these fish had the second-highest survival in 1999 (66\%; Appendix Table A-8). Survival of fish from Little White Salmon Hatchery may have been affected by disease. Pre-liberation health monitoring indicated that $56 \%$ of the sampled fish from Little White Salmon Hatchery showed gross signs of BKD, whereas no signs of BKD were evident for Carson-reared fish (Onjukka et al. 2002). Pre-liberation samples of spring chinook salmon from Umatilla Hatchery were clean - no signs of BKD and no detection of IHNV (infectious hematopoietic necrosis virus). Although Umatilla Hatchery has instigated practices to improve the spring chinook product, including longer incubation and over-winter rearing, Umatilla spring chinook do not survive as well as spring chinook from Little White Salmon and Carson hatcheries. This may be due to the warmer well water at Umatilla Hatchery, which creates a less than desirable rearing environment.

Yearling fall chinook salmon from Bonneville Hatchery were also in good health; however, survival was considerably less in 2000 than it was in 1999 (Appendix Table A-7).

It had been difficult to estimate survival of subyearling fall chinook salmon. In years prior to PIT tagging, the large and sudden influx of fish at the sampling facility forced restricted and non-representative subsampling. However, with the use of PIT tags and remote monitoring in 1999 and 2000, survival estimates were similar (Appendix Table A-7). As with all species, survival estimates for subyearling chinook remain below optimal ( $>80 \%)$, but are considerably improved from the first year's estimate (Appendix Table A-7). The potential improvement in survival may be attributed to extended water releases from McKay Reservoir through June and into July, which provides more suitable migration and river conditions. Other races, species, and origins of salmon (natural spring and fall chinook and coho salmon) also migrate as subyearlings during early summer (June and July) and are vulnerable to similar survival factors and migration conditions. For these mid-summer migrants, we recommend continued flow enhancement measures through June, into July, and beyond. We also encourage the provision of minimum flow $\left(50 \mathrm{ft}^{3} / \mathrm{s}\right)$ in the lower river corridor throughout the summer months to maintain aquatic life, provide rearing habitat, and improve survival.

Even though juvenile survival may be improving, smolt-to-adult survival of this subyearling production group remains poor (mean of $0.03 \%$ from $1991-1995$ brood years) and stray rates remain high ( $6 \%$ of adult hatchery run to Lower Granite Dam; Stonecypher et al. 2001). An 
important aspect in the migration of these subyearling fish is the speed in which they travel. The migration peak is only a few days after release and most fish are out of the basin in less than two weeks. Distance to travel from acclimation ponds to the mouth is the same as from the mouth to John Day Dam, yet fish spend considerably less time in the Umatilla River. It is highly possible that imprinting to Umatilla waters may not be complete within their migration period, especially if fish are not fully smolted at release. Instead, subyearling chinook may be imprinting on Snake River water once they exit the Umatilla River. Snake River water is a major component of Columbia River flows within this river section and tends to hug the Oregon shoreline. The advent of a $6 \%$ stray rate for subyearling fall chinook salmon into the Snake River system supports this hypothesis. A benefit to survival may be achieved if fish are acclimated longer and released later, or reared to a larger size to increase smoltification and facilitate imprinting at acclimation ponds. However, given the poor water quantity and quality conditions in the Umatilla River as summer approaches, a later release may not be practical. This program has been struggling to improve over the years, when in fact it may never succeed in meeting return goals to the Umatilla. The potential reduction of the subyearling fall chinook salmon program for 2001 to 600,000 fish will allow more intensive monitoring and evaluation to fine-tune the most optimal rearing and release strategies. We recommend another year of acclimation at the RM 56 pond to test the suitability of this lower location and urge managers to achieve minimum flows during the critical summer months, which might allow a later release.

Our reach survival tests this year indicated a substantial survival benefit to juvenile subyearling chinook salmon when released at the mouth of the Umatilla River. Mainstem detections from this release were double the detections of fish released up at RM 9 within the Umatilla River. Given the apparent increase in bass populations above Three Mile Falls Dam, the well-known bass fishery in the lower river, the abundant presence of northern pikeminnow above the dam, and the prolific presence of avian predators at the dam in May and June, subyearling fish must pass through a predator gauntlet in the lower river before reaching relative safety at the mouth. Although releasing fish at the mouth is not an option as a standard release strategy, control of predators is an option. We continue to recommend bird hazing strategies at Three Mile Falls Dam, particularly during peak migration, and support the continuance of the northern pikeminnow removal program to provide some protection to migrating smolts.

Natural salmonid production is on the rise in the Umatilla River. Production of coho salmon has notably increased since 1996 (Appendix Table A-7), particularly this year with more than 30,000 estimated migrants. These migrants (yearling and subyearling) were derived from adults returning in 1998 (3,081;CTUIR and ODFW 1999) and 1999 (3,702; CTUIR and ODFW 2000). With the return of nearly 5,000 adults in 2000 (CTUIR and ODFW 2000), production should continue at a higher level than in past years, especially if ocean conditions remain favorable.

The yearling and subyearling production of natural chinook salmon (46,764 migrants) was derived from spring chinook adult escapement in 1998 (216 adults; CTUIR and ODFW 1998) and 1999 (1,264 adults; CTUIR and ODFW 1999). In addition, 946 adult fall chinook salmon were outplanted into the Umatilla River below Pendleton in October and November 1999 (surplus from mid-Columbia hatcheries) and 280 returning adults were released back to the river above Three Mile Falls Dam (CTUIR and ODFW 2000). Although the estimate of natural production in June (30,192 migrants; Table 15) comprised both age classes of both races, the 
estimated 15,055 chinook salmon migrating from January through May were considered to be mostly spring chinook salmon. This estimate is very similar to the estimated spring chinook production in 1999 and 1998 (Appendix Table A-7). Spring chinook adults returning in 2000 and released above the dam (3,695 adults; CTUIR and ODFW 2000) may produce substantially more progeny in 2001 and 2002.

Our estimate of natural summer steelhead migrants in 2000 was the highest estimate since the beginning of monitoring in 1995 (Appendix Table A-7). Since most migrants are age-2 smolts, adult escapement in late 1997 and early 1998 (1,577 adults) contributed to the production.

Both natural coho salmon and summer steelhead have been found to rear in the McKay Creek system below McKay Reservoir (Contor et al. 2001). Previously, little rearing was possible after winter outflow from McKay reservoir was curtailed and the creek dewatered. Because of the potential for rearing, minimum winter flows $\left(10 \mathrm{ft}^{3} / \mathrm{s}\right)$ were established in McKay Creek below the reservoir to enhance natural production rearing (ODFW 2000). This added habitat should boost future production.

Migration timing of natural steelhead indicates variable timing among tributary and mainstem populations. Genetic analysis from natural steelhead migrants collected in 1996 indicated statistically significant genetic differences were found among temporal samples of steelhead (Waples, R., unpublished data). These genetic findings, coupled with the migration timing information on PIT-tagged fish, suggests that a subpopulation structure may exist within the basin, and that a different mixture of populations is represented in different temporal collections.

It is apparent that variable life histories exist for each salmonid species and race in the Umatilla Basin. As natural production has been enhanced, these life histories are becoming more evident. Chinook and coho salmon migrate as both yearling and subyearling smolts. Natural steelhead "migrants" have ranged from age-0 to age-4 fish. For the subyearling migrants, water quality and quantity is especially important during late spring and early summer. A more natural system will allow the natural life histories to be expressed, which in turn should diversify the populations and their survival strategies. Protected flows $\left(50 \mathrm{ft}^{3} / \mathrm{s}\right)$ to the mouth of the river throughout the summer months in 2000 undoubtedly enhanced the survival of various life stages, increased various elements of riverine production, and expanded habitat for rearing. This flow provision should be repeated in the future on a regular basis, if possible. Turning off and on the Umatilla River like a faucet does not support aquatic or fisheries diversity and health.

\section{Environmental Conditions and Bypass Operations}

The impacts of environmental conditions on fish behavior and survival express themselves directly and indirectly. Due to this, statistically expressing and understanding the relationship between environmental conditions and fish movements and survival is a challenge. Flows in the Umatilla River (both natural and enhanced) have been variable from year to year (Appendix Figure A-2), and fish behavior has not followed the expected coinciding trends. As a result, we 
utilized a number of different techniques this year to better understand these relationships for both natural and hatchery migrants.

In an attempt to more clearly define flow relationships with fish travel time, we incorporated a delta flow (maximum minus minimum) into our analysis in addition to mean flow. Berggren and Filardo (1993) generally reported that the larger the difference between maximum and minimum flow the longer the travel time (slower travel speed) of fish in key reaches of the Snake and Columbia rivers. We infer that if flow fluctuations adversely affect travel time of fish, then stable flows are beneficial to a faster migration. In the Umatilla River, subyearling fall chinook salmon were released during a period of relatively stable river flow with little difference between maximum and minimum flow. Travel speed significantly increased with the low delta flow during the initial migration. However, these fish traditionally emigrate quickly within a few days of release and increased temperatures also coincide with time of release.

Summer steelhead releases were made during an increase in flow followed by rapidly decreasing flows. The initial migration occurred during the high delta flow. However, the later and more abundant migrants (slower travel speed) were detected during relatively stable flows (low delta flow). River temperature was also increasing during the migration period and may have served as an additional or the sole migratory cue.

The relationship between travel speed and mean river flow is believed to be positive (Skalski et al. 1996), though hatchery fish released into the Umatilla River produced mixed results. Summer steelhead was the only species in which travel speed decreased with decreasing flows. It is hard to determine if movement of hatchery fish exhibits a true relationship with river flow due to the confounding "release effects". This year, as in the past, most hatchery chinook salmon tended to move out immediately after release, regardless of environmental conditions (Knapp et al. 1998b, 2000; Ehlers et al. 2001). Spring and subyearling fall chinook salmon both had negative correlations between travel speed and river flow, increasing in detections as the river dropped, though our analyses only incorporated flows below Pendleton (RM 55.3). It is possible that fish released at higher river sites experienced flows in the upper river that were not accounted for in the analyses and which dictated their migration.

As river flow dropped in the Umatilla River, flow enhancement strategies played an important role for summer migrants, particularly natural and hatchery subyearling chinook salmon. McKay Reservoir water releases began in late May to meet a target flow of $150 \mathrm{ft}^{3} / \mathrm{s}$ in the lower river (ODFW 2000). Unlike past years, releases from the reservoir were regulated beginning 1 July to maintain $50 \mathrm{ft}^{3} / \mathrm{s}$ in the lower river for the remainder of the summer (ODFW 2000). This procedure allowed for instream flow year round in the lower river, a challenge that had not been overcome since the initiation of flow enhancement. Year-round flows provided the opportunity for extended sampling at the West Extension Canal bypass facility and offered a unique experience to study late summer migrants.

Although flows were available for migrating fish year round, temperature was still a factor considered in relation to fish behavior. In the spring, rising temperatures may have served as a migratory cue. This year, detections of yearling spring and fall hatchery chinook salmon were correlated to increasing temperatures. Released in early March, these fish were not largely detected at the bypass facility until April when temperatures were increasing. Though also 
correlated to a decrease in flow, temperature may have been the migratory cue. Natural coho detections were also correlated with an increase in temperature, suggesting a temperature trigger for movement.

High temperatures later in the summer, however, appeared to act as a thermal barrier to migration. Collection was minimal during the highest river temperatures in late July and midAugust, but increased in September as temperatures cooled (Figures 6 and 20). (Though trap and haul operations at RM 27 prohibited fish from passing Westland Dam and traveling downriver, capture of salmonids were also few in July and August (CTUIR and ODFW 2000)). Detections of natural coho salmon and summer steelhead were high during an increasing temperature range $\left(59-63^{\circ} \mathrm{F}\right)$, and decreased as temperatures neared $68^{\circ} \mathrm{F}$. No detections were recorded above $68^{\circ} \mathrm{F}$. As river flow was regulated through McKay Reservoir releases in mid-September (to increase flows in the lower river), temperatures declined and natural fish movement increased (Figure 6).

Although movements appear to decrease with increasing temperatures, the presence of fish in the river during these high temperatures is a concern. High river temperatures can be intolerable for juvenile salmonids and may affect their survival. Temperatures in the Umatilla River neared the lethal limit of $75^{\circ} \mathrm{F}$ (Brett 1952) in July and August. Trap and Haul was conducted during these high temperatures to aid late migrants, though an in-river migration under suitable conditions remains preferred. Continuation and improvement of the current flow enhancement regime may help temper high temperatures and further increase survival of late summer migrants.

Fluctuations in enhancement flows throughout the season are associated with changes in canal and bypass operations. With minimal flow spilling over the dam, summer migrants must either pass through the east-bank fish ladder or enter the west-bank juvenile bypass facility. Canal diversion remains an important aid in attracting fish into the bypass facility. When diversion was re-initiated on 15 June following a Phase I operation, collection of fish entering the bypass facility substantially increased; nearly 3,000 fish were collected in the overnight sampling period at a 50\% sample rate (Figure 6). Many of these fish were natural chinook salmon. Accordingly, trap efficiency of natural subyearling chinook salmon was highly correlated with diversion rate. Canal diversion is important in attracting fish to the bypass when flows are decreasing to summer levels, and especially during low summer flows. This operation minimizes facility-related delays in migration.

When diversion is curtailed and Phase I pump exchange initiated, operations of the riverreturn pipe are important in providing proper flow conditions for bypassing fish. Conveyance of water through this 21-inch pipe improves water flow and velocity at the canal headgates, attracting fish into the bypass facility (Cameron et al. 1998). For example, closure of the riverreturn pipe from 4 - 21 May coincided with decreased detections at the bypass facility (Figure 25). The river-return pipe must remain at a maximum of $40 \%$ open during Phase I operations, with no or partial diversion, to maintain bypass efficiency. 


\section{Resident Fish and Predators}

Although collection of northern pikeminnow was relatively low throughout the year, the final collection in early October 2000 yielded hundreds of these fish, many of predatory size. This influx may have been due to a rainstorm with subsequent increased flows. More importantly, it became apparent that northern pikeminnow are very abundant in the pooled section above the dam. Their predatory affect may be significant, especially for late-season migrants. Also significant is the presence and abundance of avian predators at Three Mile Falls Dam. Management of these predators should be considered if improving survival as much as practical is a serious endeavor.

\section{Acknowledgements}

Special recognition goes to Mark Smith for many hours working the trap and collecting the data. We also acknowledge Wes Haynes, who assisted the project through the summer as part of the Apprenticeship in Science and Engineering Program. We are grateful for the assistance of field personnel and administrators of the Bureau of Reclamation and West Extension Irrigation District. Recognition is also given to the fish passage facility's O\&M staff for assisting us with sampling facility operations, repair, and modifications. We thank ODFW Pathology staff in La Grande for analyzing the fish samples. We also appreciate the assistance of Irrigon Hatchery personnel to accommodate our tagging and fish holding needs. We thank the staff of the Umatilla Hatchery Monitoring and Evaluation project for assistance during PIT tagging. Final appreciation goes to Jay Marcotte of the Bonneville Power Administration for his project support. 


\section{LITERATURE CITED}

Berggren, T.J. and M.J. Filardo. 1993. An analysis of variables influencing the migration of juvenile salmonids in the Columbia River Basin. North American Journal of Fisheries Management. 13:48-63.

Boyce, R.R. 1986. A comprehensive plan for rehabilitation of anadromous fish stocks in the Umatilla River basin. Final report of Oregon Department of Fish and Wildlife to the Bonneville Power Administration, Portland, Oregon.

Brett, J.R. 1952. Temperature tolerance in young Pacific salmon, genus Oncorhynchus. Journal of the Fisheries Research Board of Canada, 9: 265-323.

Burnham, K.P., D.R. Anderson, G.C. White, C. Brownie, and K.H. Pollock. 1987. Design and analysis methods for fish survival experiments based on release-recapture. American Fisheries Society Monograph 5: 1-437.

Cameron, W.A. and S.M. Knapp. 1993. Pages 5-48 in S.M. Knapp, editor. Evaluation of juvenile fish bypass and adult fish passage facilities at water diversions in the Umatilla River. Annual progress report 1991-1992 to Bonneville Power Administration, Portland, Oregon.

Cameron, W.A., S.M. Knapp, and B.P. Schrank. 1994. Evaluation of juvenile fish bypass and adult fish passage facilities at water diversions in the Umatilla River. Annual progress report 1992-1993 to Bonneville Power Administration, Portland, Oregon.

Cameron, W.A., S.M. Knapp, and B.P. Schrank. 1995. Pages 1-98 in S.M. Knapp, editor. Evaluation of juvenile fish bypass and adult fish passage facilities at water diversions on the Umatilla River. Annual progress report 1993-1994 to Bonneville Power Administration, Portland, Oregon.

Cameron, W.A., S.M. Knapp, and R.W. Carmichael. 1997. Evaluation of juvenile salmonid bypass facilities and passage at water diversions on the lower Umatilla River. Final report to Bonneville Power Administration, Portland, Oregon.

Cameron, W.A., S.M. Knapp, and R.W. Carmichael. 1998. Pages 131-162 (Report B) in Knapp et al. 1998b. Evaluation of juvenile salmonid outmigration and survival in the lower Umatilla River basin. Annual progress report 1996-1997 to Bonneville Power Administration, Portland, Oregon.

CBFWA (Columbia Basin Fish and Wildlife Authority), PIT Tag Steering Committee. 1999. PIT Tag Marking Procedures Manual, Version 2.0.

Chess, D.W., W.A. Cameron, R.W. Stonecypher, Jr., and R.W. Carmichael. 2002. Umatilla Hatchery monitoring and evaluation. Annual progress report 1999-2000 to the Bonneville Power Administration, Portland, Oregon. 
Close, D.A. In Preparation. Restoration plan for Pacific lampreys (Lampetra tridentata) in the Umatilla River, Oregon. Report to Bonneville Power Administration, Portland, Oregon.

Close, D.A. 2000. Pacific lamprey research and restoration project. Annual report 1998 to Bonneville Power Administration, Portland, Oregon.

Close, D.A. 2001. Pacific lamprey research and restoration project. Annual report 1999 to Bonneville Power Administration, Portland, Oregon.

Columbia Basin Pacific Lamprey Technical Work Group. 1999. Planning of Columbia basin Pacific lamprey projects and needs. A report to the Northwest Power Planning Council and Bonneville Power Administration, July 1999.

Contor, C.R., E. Hoverson, and P. Kissner. 1995. Umatilla basin natural production monitoring and evaluation. Annual progress report 1993-1994 to Bonneville Power Administration, Portland, OR.

Contor, C.R., E. Hoverson, P. Kissner, and J. Volkman. 1996. Umatilla basin natural production monitoring and evaluation. Annual progress report 1994-1995 to Bonneville Power Administration, Portland, Oregon.

Contor, C.R., E. Hoverson, P. Kissner, and J. Volkman. 1997. Umatilla basin natural production monitoring and evaluation. Annual progress report 1995-1996 to Bonneville Power Administration, Portland, Oregon.

Contor, C.R., E. Hoverson, and P. Kissner. 1998. Umatilla basin natural production monitoring and evaluation. Annual progress report 1996-1997 to Bonneville Power Administration, Portland, Oregon.

Contor, C.R. and P. Kissner. 2000. Umatilla basin natural production monitoring and evaluation. Annual progress report 1997-1998 to Bonneville Power Administration, Portland, Oregon.

CTUIR (Confederated Tribes of the Umatilla Indian Reservation). 1984. Umatilla basin recommended salmon and steelhead habitat (hatchery and passage) improvement measures. Mission, Oregon.

CTUIR (Confederated Tribes of the Umatilla Indian Reservation). 1994. Umatilla basin natural production monitoring and evaluation. Annual progress report 1992-1993 to Bonneville Power Administration, Portland, Oregon.

CTUIR (Confederated Tribes of the Umatilla Indian Reservation) and ODFW (Oregon Department of Fish and Wildlife). 1989. Umatilla River subbasin - salmon and steelhead plan. Prepared for the Northwest Power Planning Council for Columbia Basin system planning. 
CTUIR (Confederated Tribes of the Umatilla Indian Reservation) and ODFW (Oregon Department of Fish and Wildlife). 1990. Umatilla hatchery master plan. Prepared for the Northwest Power Planning Council, Portland, Oregon.

CTUIR (Confederated Tribes of the Umatilla Indian Reservation) and ODFW (Oregon Department of Fish and Wildlife). 1997. Trapping and transportation of adult and juvenile salmon in the lower Umatilla River in northeast Oregon, Annual progress report 1996-1997 to Bonneville Power Administration, Portland, Oregon.

CTUIR (Confederated Tribes of the Umatilla Indian Reservation) and ODFW (Oregon Department of Fish and Wildlife). 1998. Trapping and transportation of adult and juvenile salmon in the lower Umatilla River in northeast Oregon, Annual progress report 1997-1998 to Bonneville Power Administration, Portland, Oregon.

CTUIR (Confederated Tribes of the Umatilla Indian Reservation) and ODFW (Oregon Department of Fish and Wildlife). 1998. Fish passage operations in the Umatilla River, Annual progress report 1998-1999 to Bonneville Power Administration, Portland, Oregon.

CTUIR (Confederated Tribes of the Umatilla Indian Reservation) and ODFW (Oregon Department of Fish and Wildlife). 1999. Umatilla River passage operations program. Annual progress report 1998-1999 to Bonneville Power Administration, Portland, Oregon.

CTUIR (Confederated Tribes of the Umatilla Indian Reservation) and ODFW (Oregon Department of Fish and Wildlife). 2000. Umatilla River passage operations program. Annual progress report 1999-2000 to Bonneville Power Administration, Portland, Oregon.

Dauble, D.D., J. Skalski, A. Hoffman, and A. E. Giorgi. 1993. Evaluation and application of statistical methods for estimating smolt survival. Report to the Bonneville Power Administration, Portland, Oregon.

Efron, B. and R. Tibshirani. 1986. Bootstrap methods for standard errors, confidence intervals, and other measures of statistical accuracy. Statistical Science 1(1): 54-77.

Ehlers, D.L., S.M. Knapp, S.M. Jewett, and R.W. Carmichael. 2001. Evaluation of juvenile salmonid outmigration and survival in the lower Umatilla River basin. 1998-1999 annual progress report to the Bonneville Power Administration, Portland, Oregon.

Focher, S.M., R.W. Carmichael, M.C. Hayes, R.W. Stonecypher, Jr., W.J. Groberg, Jr., S.T. Onjukka, and K. Waln. 1998. Umatilla Hatchery Monitoring and Evaluation. Annual progress report 1995-1996 to Bonneville Power Administration, Portland, Oregon. 
Hayes, M.C., S.M. Knapp, and A.A. Nigro. 1992. Pages 53-103 in S.M. Knapp, editor. Evaluation of juvenile fish bypass and adult fish passage facilities at water diversions in the Umatilla River. Annual and interim progress reports to Bonneville Power Administration, Portland, Oregon.

Hayes, M.C., R.W. Carmichael, S.M. Focher, N.L. Hurtado, M.L. Keefe, G.W. Love, W.J. Groberg, Jr., S.T. Onjukka, and K. Waln. 1996a. Umatilla Hatchery Monitoring and Evaluation. Annual progress report 1993-1994 to Bonneville Power Administration, Portland, Oregon.

Hayes, M.C., R.W. Carmichael, S.M. Focher, W.J. Groberg, Jr., S.T. Onjukka, R.W. Stonecypher, Jr., and K. Waln. 1996b. Umatilla Hatchery Monitoring and Evaluation. Annual progress report 1994-1995 to Bonneville Power Administration, Portland, Oregon.

Hayes, M.C., R.W. Carmichael, S.M. Focher, R.W. Stonecypher, Jr., W.J. Groberg, Jr., S.T. Onjukka, K.A. Brown, and K.Waln. 1999a. Umatilla Hatchery Monitoring and Evaluation. Annual progress report 1996-1997 to the Bonneville Power Administration, Portland, Oregon.

Hayes, M.C., W.A. Cameron, R.W. Carmichael, R.W. Stonecypher, Jr., S.T. Onjukka, W.J. Groberg, Jr., K.A. Brown, and K. Waln. 1999b. Umatilla Hatchery Monitoring and Evaluation. Annual progress report 1997-1998 to the Bonneville Power Administration, Portland, Oregon.

Jackson, A.D., D.R. Hatch, B.L. Parker, D.A. Close, M.S. Fitzpatrick, and H. Li. 1997. Pacific lamprey research and restoration project. Annual report 1997 to Bonneville Power Administration, Portland, Oregon.

Keefe, M.L., R.W. Carmichael, R.A. French, W.J. Groberg, Jr., and M.C. Hayes. 1993. Fish research project - Oregon. Umatilla Hatchery Monitoring and Evaluation. Annual progress report 1992 to Bonneville Power Administration, Portland, Oregon.

Keefe, M.L., R.W. Carmichael, S.M. Focher, W.J. Groberg, Jr., and M.C. Hayes. 1994. Umatilla Hatchery Monitoring and Evaluation. Annual progress report 1993 to Bonneville Power Administration, Portland, Oregon.

Knapp, S.M. and D.L. Ward. 1990. Operation and evaluation of the juvenile fish bypass system in the West Extension Irrigation District Canal at Three Mile Falls Dam. In A.A. Nigro, editor. Evaluation of juvenile fish bypass and adult fish passage facilities at Three Mile Falls Dam, Umatilla River. Annual progress report 1989-1990 to Bonneville Power Administration, Portland, Oregon. 
Knapp, S.M., J.C. Kern, W.A. Cameron, S.L. Shapleigh, and R.W. Carmichael. 1996. Evaluation of juvenile salmonid outmigration and survival in the lower Umatilla River basin. Annual progress report 1994-1995 to Bonneville Power Administration, Portland, Oregon.

Knapp, S.M., J.C. Kern, W.A. Cameron, S.M. Snedaker, and R.W. Carmichael. 1998a. Evaluation of juvenile salmonid outmigration and survival in the lower Umatilla River basin. Annual progress report 1995-1996 to Bonneville Power Administration, Portland, Oregon.

Knapp, S.M., W.A. Cameron, J.C. Kern, and R.W. Carmichael. 1998b. Evaluation of juvenile salmonid outmigration and survival in the lower Umatilla River basin. Annual progress report 1996-1997 to Bonneville Power Administration, Portland, Oregon.

Knapp, S.M., D.L. Ehlers, S.M. Focher, T.A. Jones, and J.C. Kern, and R.W. Carmichael. 2000. Evaluation of juvenile salmonid outmigration and survival in the lower Umatilla River basin. Annual progress report 1997-1998 to Bonneville Power Administration, Portland, Oregon.

Knapp, S.M., D.L. Ehlers, S.M. Jewett, and R.W. Carmichael. In Preparation. Evaluation of juvenile salmonid outmigration and survival in the lower Umatilla River basin. Annual progress report 2000-2001 to Bonneville Power Administration, Portland, Oregon.

NPPC (Northwest Power Planning Council). 1984. Columbia River Basin Fish and Wildlife Program, Portland, Oregon.

NPPC (Northwest Power Planning Council). 1987. Columbia River Basin Fish and Wildlife Program (as amended), Portland, Oregon.

NPPC (Northwest Power Planning Council). 1994. Columbia River Basin Fish and Wildlife Program, Portland, Oregon.

ODFW (Oregon Department of Fish and Wildlife). 2000. Umatilla hatchery and basin annual operating plan for the period of October 12000 - September 30, 2001. A report to Bonneville Power Administration, Portland, Oregon.

Onjukka, S.T., G.M. Claire, W.J. Groberg, Jr., B.M. Farman and K.A. Brown. 2002. Fish health monitoring and evaluation (Report B). in D.W. Chess, editor. Umatilla Hatchery monitoring and evaluation. 1999-2000 annual report to Bonneville Power Administration, Portland, Oregon.

Roper, B.B. and D.L. Scarnecchia. 1999. Emigration of age-0 chinook salmon (Oncorhynchus tshawytscha) smolts from the upper South Umpqua River basin, Oregon, USA. Can. J. Fish. Aquat. Sci. 56:939-946.

SAS Institute, Inc. 1990. SAS language: reference, version 6.12. Cary, North Carolina. 
Saul, D., C. Rabe, A. Davidson, and D. Rollins. 2001. Umatilla Subbasin Summary. Report to the Northwest Power Planning Council for the Columbia Plateau Rolling Provincial Review, July 2001.

Skalaski, J.R., R.L. Townsend, R.F. Donnelly, and R.W. Hilborn. 1996. The relationship between survival of Columbia River fall chinook salmon and in-river environmental factors. Analysis of historic data for juvenile and adult salmonid production: Phase II. Final report to Bonneville Power Administration, Portland, Oregon.

Snedecor, G.W. and W.G. Cochran. 1989. Statistical Methods. $8^{\text {th }}$ Edition. Iowa State University Press, Ames, Iowa.

Stone, J., T. Sundlov, S. Barndt, and T. Coley. 2001. Evaluate habitat use and population dynamics of lampreys in Cedar Creek. Annual report to Bonneville Power Administration, Portland, Oregon.

Stonecypher, R.W., Jr., W.A. Cameron, R.W. Carmichael, M.C. Hayes, C.K. Hall, S.T. Onjukka, G.M. Claire, W.J. Groberg, Jr., B.M. Farman, and K.A. Brown. 2001. Umatilla Hatchery Monitoring and Evaluation. Annual progress report 1998-1999 to Bonneville Power Administration, Portland, Oregon.

Thedinga, J.F., M.L. Murphy, S.W. Johnson, J.M. Lorenz, and K.V. Koski. 1994. Determination of smolt yield with rotary-screw traps in the Situk River, Alaska, to predict effects of glacial flooding. North American Journal of Fisheries Management 14:837-851.

USBR (U.S. Bureau of Reclamation). 1988. Umatilla basin project - planning report and final environmental impact statement. Statement Number FES 88-4, filed February 12, 1988.

USBR (U.S. Bureau of Reclamation) and BPA (Bonneville Power Administration). 1989. Umatilla basin project. Initial project workplan presented to the Northwest Power Planning Council, May 1989. 
Table 1. Type and number of PIT-tag files created during monitoring activities at West Extension Canal, Umatilla River, 2000.

\begin{tabular}{lcc}
\hline File type & Number created & Dates created \\
\hline & & \\
Interrogation & 900 & $3 / 5 / 00-7 / 20 / 00$ \\
Monitor & 147 & $3 / 6 / 00-9 / 26 / 00$ \\
Trap Efficiency & 34 & $3 / 11 / 00-7 / 7 / 00$ \\
Tagging (at trap) & 10 & $4 / 6 / 00-9 / 19 / 00$ \\
Tagging (reach survival) & 39 & $3 / 7 / 00-5 / 25 / 00$ \\
\hline
\end{tabular}

Table 2. PIT-tagged fish from different hatcheries and hatchery rearing strategies detected at West Extension Canal, RM 3.7, Umatilla River, March - September 2000.

\begin{tabular}{|c|c|c|c|c|c|c|}
\hline \multirow{2}{*}{$\begin{array}{l}\text { Hatchery }^{a} \text {, } \\
\text { rearing }^{b}\end{array}$} & \multirow{2}{*}{$\begin{array}{c}\text { Raceway } \\
\text { section }\end{array}$} & \multirow{2}{*}{$\begin{array}{l}\text { Number } \\
\text { released }^{c}\end{array}$} & \multirow{2}{*}{$\begin{array}{l}\text { Release } \\
\text { date }^{d}\end{array}$} & \multicolumn{2}{|c|}{ Number detected } & \multirow{2}{*}{$\begin{array}{l}\text { Percent } \\
\text { detection }\end{array}$} \\
\hline & & & & Hand Remote & Total & \\
\hline
\end{tabular}

Spring Chinook Salmon

UFH

$\begin{array}{lllllllll}\text { Oregon } & \mathrm{O}^{\prime} \mathrm{A}^{f} & 266 & 3 / 6 & 1 & 4 & 5 & 1.9 & \\ \text { Oregon } & \mathrm{O}^{f} & 263 & 3 / 6 & 0 & 5 & 5 & 1.9 & 1.9 \\ \text { Oregon } & \text { O5A } & 291 & 3 / 6 & 0 & 3 & 3 & 1.0 & \\ \text { Oregon } & \text { O5B } & 279 & 3 / 6 & 0 & 2 & 2 & 0.7 & 0.9 \\ \text { Michigan } & \text { M1A } & 253 & 3 / 6 & 0 & 6 & 6 & 2.4 & \\ \text { Michigan } & \text { M1B } & 249 & 3 / 6 & 1 & 1 & 2 & 0.8 & \\ \text { Michigan } & \text { M1C } & 263 & 3 / 6 & 0 & 2 & 2 & 0.8 & 1.3\end{array}$

LWS

$\begin{array}{lllllccrr}\text { Standard } & - & 297 & 3 / 6 & 0 & 6 & 6 & 2.0 & \\ \text { Standard } & - & 270 & 4 / 6 & 0 & 23 & 23 & 8.5 & 5.1\end{array}$

$\mathrm{CFH}$

$\begin{array}{lllllllll}\text { Standard } & - & 297 & 4 / 6 & 5 & 56 & 61 & 20.2 & 20.5\end{array}$

a $U F H=$ Umatilla Fish Hatchery, LWS = Little White Salmon Hatchery, CFH = Carson Fish Hatchery, BFH = Bonneville Fish Hatchery

$b$ Oregon $=$ reared in standard raceway, Michigan $=$ reared in oxygenated raceway, low density $=$ reared at $200 \mathrm{~K}$, med . density $=$ reared at $300 \mathrm{~K}$, and high density $=$ reared at $400 \mathrm{~K}$.

c Spring chinook salmon released at RM 80, yearling fall chinook salmon released at $R M$ 73.5, subyearling fall chinook salmon released at RM 73.5 and 56, and summer steelhead released at RM 79 and 64.5.

$d$ Release dates for spring and yearling fall chinook salmon and summer steelhead are start of volitional releases. Release dates for subyearling fall chinook salmon are forced releases.

e Total detection for specific rearing strategies.

$f$ UFH spring chinook reared in ponds $O 4 A$ and $O 4 B$ were over wintered at the Imeques (RM 80) acclimation facility. 
Table 2. Continued.

\begin{tabular}{|c|c|c|c|c|c|c|c|c|}
\hline \multirow{2}{*}{$\begin{array}{l}\text { Hatchery }{ }^{a}, \\
\text { rearing }{ }^{b}\end{array}$} & \multirow{2}{*}{$\begin{array}{c}\text { Raceway } \\
\text { section }\end{array}$} & \multirow{2}{*}{$\begin{array}{l}\text { Number } \\
\text { released }^{c}\end{array}$} & \multirow{2}{*}{$\begin{array}{l}\text { Release } \\
\text { date }^{d}\end{array}$} & \multicolumn{3}{|c|}{ Number detected } & \multirow{2}{*}{$\begin{array}{c}\text { Percent } \\
\text { detection }\end{array}$} & \multirow{2}{*}{$\begin{array}{c}\text { Total }^{e} \\
\text { detection }^{2}\end{array}$} \\
\hline & & & & Hand & Remote & Total & & \\
\hline \multicolumn{9}{|c|}{ Yearling Fall Chinook Salmon } \\
\hline \multicolumn{9}{|l|}{ BFH } \\
\hline Standard & - & 286 & $3 / 6$ & 1 & 9 & 10 & 3.5 & \\
\hline Standard & - & 289 & $4 / 6$ & 3 & 54 & 57 & 19.7 & 11.7 \\
\hline \multicolumn{9}{|c|}{ Subyearling Fall Chinook Salmon } \\
\hline \multicolumn{9}{|l|}{ UFH } \\
\hline Low density & M3A & 594 & $5 / 24$ & 3 & 177 & 180 & 30.3 & \\
\hline Low density & M3B & 588 & $5 / 24$ & 1 & 195 & 196 & 33.3 & \\
\hline Low density & $\mathrm{M} 3 \mathrm{C}$ & 588 & $5 / 23$ & 1 & 182 & 183 & 31.1 & 31.6 \\
\hline Low density & $\mathrm{M} 3 \mathrm{~A}^{g}$ & 700 & $5 / 24$ & 0 & 245 & 245 & 35.0 & 35.0 \\
\hline Med. density & M1A & 596 & $5 / 24$ & 0 & 219 & 219 & 36.7 & \\
\hline Med. density & M1B & 584 & $5 / 24$ & 1 & 214 & 215 & 36.8 & \\
\hline Med. density & M1C & 587 & $5 / 23$ & 0 & 150 & 150 & 25.6 & 33.0 \\
\hline High density & M2A & 570 & $5 / 24$ & 1 & 217 & 218 & 38.2 & \\
\hline High density & M2B & 594 & $5 / 24$ & 0 & 195 & 195 & 32.8 & \\
\hline High density & $\mathrm{M} 2 \mathrm{C}$ & 594 & $5 / 23$ & 0 & 175 & 175 & 29.5 & 33.4 \\
\hline \multicolumn{9}{|c|}{ Summer Steelhead } \\
\hline \multicolumn{9}{|l|}{ UFH } \\
\hline Large grade & ${\mathrm{M} 8 \mathrm{C}^{h}}$ & 233 & $3 / 30$ & 2 & 34 & 36 & 15.5 & 15.5 \\
\hline Large grade & $\mathrm{M} 8 \mathrm{~B}^{h}$ & 252 & $4 / 3$ & 1 & 19 & 20 & 7.9 & 7.9 \\
\hline Small grade & M8A ${ }^{h}$ & 565 & $4 / 24$ & 0 & 47 & 47 & 8.3 & 8.3 \\
\hline Small grade & ${\mathrm{M} 8 \mathrm{~A}^{i}}^{i}$ & 392 & $3 / 30$ & 0 & 40 & 40 & 10.2 & 10.2 \\
\hline Small grade & ${\mathrm{M} 8 \mathrm{~A}^{i}}^{i}$ & 398 & $4 / 3$ & 1 & 18 & 19 & 4.8 & 4.8 \\
\hline
\end{tabular}

$g$ Test fish were held at the hatchery until release, not acclimated.

${ }^{h}$ M8C and M8A released at Minthorn (RM 64.5) and M8B released at Bonifer (RM 2 of Meacham creek).

${ }^{i}$ Small grade test fish released at Minthorn (RM 64.5) on 3/30 and at Bonifer (RM 2 of Meacham creek) on 4/3. 
Table 3. Natural fish PIT tagged by CTUIR, released at upper Umatilla River sites, and detected at West Extension Canal (RM 3.7), Umatilla River, March - September 2000.

\begin{tabular}{lcccccc}
\hline Release & Release & Number & Number detected & Total & Percent \\
site & month & tagged & Hand & Remote & detected & detection \\
\hline
\end{tabular}

Chinook Salmon

\begin{tabular}{|c|c|c|c|c|c|c|}
\hline Umatilla River & December 1999 & 34 & 0 & 1 & 1 & 2.9 \\
\hline (RM 80) & January 2000 & 19 & 0 & 0 & 0 & 0.0 \\
\hline & April 2000 & 1 & 0 & 0 & 0 & 0.0 \\
\hline & May 2000 & 2 & 0 & 0 & 0 & 0.0 \\
\hline Minthorn & December 1999 & 1 & 0 & 0 & 0 & 0.0 \\
\hline & & Coho & & & & \\
\hline Umatilla River & December 1999 & 26 & 0 & 3 & 3 & 1.2 \\
\hline (RM 80) & April 2000 & 22 & 0 & 6 & 6 & 27.3 \\
\hline & May 2000 & 28 & 0 & 6 & 6 & 21.4 \\
\hline Squaw Creek & November 1999 & 36 & 0 & 4 & 4 & 11.1 \\
\hline$(\mathrm{RM} 77)$ & December 1999 & 5 & 0 & 1 & 1 & 20.0 \\
\hline & April 2000 & 6 & 0 & 0 & 0 & 0.0 \\
\hline $\begin{array}{l}\text { Buckaroo Creek } \\
\text { (RM 73) }\end{array}$ & December 1999 & 30 & 0 & 2 & 2 & 6.7 \\
\hline $\begin{array}{l}\text { Minthorn } \\
\text { (RM 64.5) }\end{array}$ & December 1999 & 17 & 0 & 1 & 1 & 5.9 \\
\hline $\begin{array}{l}\text { McKay Creek } \\
(\mathrm{RM} 51)\end{array}$ & December 1999 & 365 & 0 & 13 & 13 & 3.6 \\
\hline
\end{tabular}

Summer Steelhead

\begin{tabular}{lcccccc} 
Umatilla River & December 1999 & 80 & 0 & 7 & 7 & 8.8 \\
(RM 80) & January 2000 & 5 & 0 & 0 & 0 & 0.0 \\
& April 2000 & 643 & 1 & 93 & 94 & 14.6 \\
& May 2000 & 179 & 1 & 29 & 30 & 16.8 \\
Squaw Creek & November 1999 & 34 & 1 & 4 & 5 & 14.7 \\
(RM 77) & December 1999 & 49 & 0 & 2 & 2 & 4.1 \\
& April 2000 & 20 & 0 & 3 & 3 & 15.0 \\
$\begin{array}{l}\text { Buckaroo Creek } \\
\text { (RM 73) }\end{array}$ & December 1999 & 54 & 0 & 1 & 1 & 1.9 \\
\hline
\end{tabular}


Table 3. Continued.

\begin{tabular}{|c|c|c|c|c|c|c|}
\hline \multirow{2}{*}{$\begin{array}{l}\text { Release } \\
\text { site }\end{array}$} & \multirow{2}{*}{$\begin{array}{l}\text { Release } \\
\text { month }\end{array}$} & \multirow{2}{*}{$\begin{array}{c}\text { Number } \\
\text { tagged }\end{array}$} & \multicolumn{2}{|c|}{ Number detected } & \multirow{2}{*}{$\begin{array}{c}\text { Total } \\
\text { detected } \\
\end{array}$} & \multirow{2}{*}{$\begin{array}{l}\text { Percent } \\
\text { detection }\end{array}$} \\
\hline & & & Hand & Remote & & \\
\hline \multicolumn{7}{|c|}{ Summer Steelhead } \\
\hline $\begin{array}{l}\text { Minthorn } \\
\text { (RM 64.5) }\end{array}$ & December 1999 & 19 & 0 & 2 & 2 & 10.5 \\
\hline $\begin{array}{l}\text { Moonshine Creek } \\
\text { (RM 64) }\end{array}$ & December 1999 & 16 & 0 & 0 & 0 & 0.0 \\
\hline $\begin{array}{l}\text { Cottonwood Creek } \\
\text { (RM 63) }\end{array}$ & April 2000 & 21 & 0 & 0 & 0 & 0.0 \\
\hline $\begin{array}{l}\text { McKay Creek } \\
(\mathrm{RM} 51)\end{array}$ & December 1999 & 119 & 0 & 7 & 7 & 5.9 \\
\hline \multicolumn{7}{|c|}{ Birch Creek Tributaries (RM 48) } \\
\hline East Fork (RM 16) & April 2000 & 163 & 0 & 8 & 8 & 4.9 \\
\hline $\begin{array}{l}\text { West Fork } \\
\text { (RM 16) }\end{array}$ & April 2000 & 94 & 0 & 1 & 1 & 1.1 \\
\hline $\begin{array}{l}\text { Pearson Creek } \\
(\mathrm{RM} 11)\end{array}$ & April 2000 & 58 & 0 & 2 & 2 & 3.4 \\
\hline
\end{tabular}


Table 4. PIT-tag recoveries at mainstem Columbia River islands from hatchery juvenile salmonids released for reach-specific survival tests in the Umatilla River, 2000. Islands are sites for bird colonies.

\begin{tabular}{|c|c|c|c|c|c|c|c|c|c|c|c|c|}
\hline \multirow[b]{2}{*}{$\begin{array}{l}\text { Release } \\
\text { site }\end{array}$} & \multirow[b]{2}{*}{$\begin{array}{c}\text { Release } \\
\text { date }\end{array}$} & \multirow[b]{2}{*}{$\begin{array}{l}\text { Number } \\
\text { released }\end{array}$} & \multicolumn{8}{|c|}{ Recovery site $^{a}$ (date) } & \multirow[b]{2}{*}{$\begin{array}{c}\text { Total } \\
\text { recovery }\end{array}$} & \multirow[b]{2}{*}{$\begin{array}{l}\text { Percent } \\
\text { recovery }\end{array}$} \\
\hline & & & $\begin{array}{c}\text { ESANIS } \\
(9 / 6 \& 11 / 7)\end{array}$ & $\begin{array}{c}\text { RICEIS } \\
(9 / 29)\end{array}$ & $\begin{array}{c}\text { LMEMIS } \\
(10 / 11)\end{array}$ & $\begin{array}{l}\text { LMILIS } \\
(10 / 12)\end{array}$ & $\begin{array}{l}\text { 3MILIS } \\
(10 / 25)\end{array}$ & $\begin{array}{c}\text { CRESIS } \\
(8 / 29)\end{array}$ & $\begin{array}{c}\text { RICHIS } \\
(12 / 13)\end{array}$ & $\begin{array}{c}\text { IS18 } \\
(12 / 6)\end{array}$ & & \\
\hline
\end{tabular}

\begin{tabular}{|c|c|c|c|c|c|c|c|c|c|c|c|c|}
\hline site & date & released & $(9 / 6 \& 11 / 7)$ & $(9 / 29)$ & $(10 / 11)$ & $(10 / 12)$ & $(10 / 25)$ & $(8 / 29)$ & $(12 / 13)$ & $(12 / 6)$ & recovery & recover \\
\hline \multicolumn{13}{|c|}{ Spring Chinook Salmon } \\
\hline RM 9 & $3 / 7-9$ & 777 & 10 & 0 & 0 & 0 & 1 & 0 & 0 & 0 & 11 & 1.4 \\
\hline RM 27 & $3 / 7-9$ & 1,000 & 11 & 2 & 0 & 0 & 1 & 0 & 0 & 0 & 14 & 1.4 \\
\hline RM 80 & $3 / 7-9$ & 1,002 & 6 & 1 & 0 & 1 & 0 & 0 & 0 & 0 & 8 & 0.8 \\
\hline & & & & & & & & & & Total & 33 & 1.2 \\
\hline
\end{tabular}

\begin{tabular}{|c|c|c|c|c|c|c|c|c|c|c|c|c|}
\hline RM 0 & $5 / 23-25$ & 1,892 & 33 & 1 & 1 & 5 & 1 & 0 & 0 & 0 & 41 & 2.2 \\
\hline RM 9 & $5 / 23-25$ & 596 & 8 & 1 & 0 & 1 & 0 & 0 & 0 & 0 & 10 & 1.7 \\
\hline RM 27 & $5 / 23-25$ & 446 & 8 & 0 & 1 & 0 & 0 & 0 & 0 & 0 & 9 & 2.0 \\
\hline RM 56 & $5 / 23-25$ & 448 & 6 & 0 & 0 & 0 & 0 & 2 & 0 & 1 & 9 & 2.0 \\
\hline RM 73.5 & $5 / 23-25$ & 447 & 4 & 0 & 0 & 0 & 0 & 4 & 0 & 0 & 8 & 1.8 \\
\hline & & & & & & & & & & Total & 77 & 2.0 \\
\hline
\end{tabular}

Summer Steelhead

\begin{tabular}{|c|c|c|c|c|c|c|c|c|c|c|c|c|}
\hline RM 9 & $4 / 10-12$ & 383 & 9 & 1 & 0 & 0 & 4 & 1 & 0 & 1 & 16 & 4.2 \\
\hline RM 27 & $4 / 10-12$ & 381 & 14 & 2 & 0 & 1 & 3 & 1 & 0 & 0 & 21 & 5.5 \\
\hline RM 48 & $4 / 10-12$ & 564 & 8 & 3 & 1 & 0 & 2 & 2 & 0 & 0 & 16 & 2.8 \\
\hline RM 64.5 & $4 / 10-12$ & 569 & 12 & 1 & 0 & 2 & 3 & 0 & 1 & 0 & 19 & 3.3 \\
\hline \multirow[t]{2}{*}{ RM 79} & $4 / 10-12$ & 569 & 6 & 1 & 0 & 1 & 1 & 1 & 0 & 1 & 11 & 1.9 \\
\hline & & & & & & & & & & Total & 83 & 3.4 \\
\hline
\end{tabular}

a ESANIS = East Sand Island (RM 5), RICEIS = Rice Island (RM 21), LMEMIS = Little Memaloose Island (RM 195), LMILIS = Little Miller Island (RM 206), 3MILIS = Three Mile Island (RM 256), CRESIS = Crescent Island (RM 317),), RICHIS = Richland Island (RM 339), and IS18 = Island 18 (RM 341). 
Table 5. Holding survival and tag retention of PIT-tagged hatchery and natural juvenile salmonids used in trap efficiency tests at West Extension Canal (RM 3.7), Umatilla River, March - July 2000.

\begin{tabular}{|c|c|c|c|c|c|c|c|}
\hline $\begin{array}{l}\text { Mark } \\
\text { date }\end{array}$ & $\begin{array}{c}\text { Number } \\
\text { held }\end{array}$ & $\begin{array}{c}\text { Mean } \\
\text { temperature }^{a}\end{array}$ & $\begin{array}{c}\text { Hours } \\
\text { held }\end{array}$ & $\begin{array}{c}\text { Number } \\
\text { mortalities }\end{array}$ & $\begin{array}{l}\text { Number of } \\
\text { lost tags }\end{array}$ & $\begin{array}{c}\text { Percent } \\
\text { survival }^{b}\end{array}$ & $\begin{array}{l}\text { Percent tag } \\
\text { retention }\end{array}$ \\
\hline \multicolumn{8}{|c|}{$\begin{array}{c}\text { Hatchery } \\
\text { Spring Chinook Salmon }\end{array}$} \\
\hline $3 / 11$ & 75 & 8.5 & 25.1 & 0 & 0 & 100.0 & 100.0 \\
\hline $3 / 30$ & 18 & 9.5 & 21.0 & 0 & 0 & 100.0 & 100.0 \\
\hline $4 / 1$ & 49 & 11.3 & 29.0 & 0 & 0 & 100.0 & 100.0 \\
\hline $4 / 4$ & 75 & 11.5 & 27.0 & 0 & 0 & 100.0 & 100.0 \\
\hline $4 / 13$ & 75 & 12.0 & 25.9 & 0 & 0 & 100.0 & 100.0 \\
\hline $4 / 20$ & 75 & 12.3 & 27.3 & 0 & 0 & 100.0 & 100.0 \\
\hline $4 / 26$ & 70 & 14.3 & 28.0 & 0 & 0 & 100.0 & 100.0 \\
\hline $5 / 2$ & 71 & 14.5 & 30.7 & 0 & 0 & 100.0 & 100.0 \\
\hline \multicolumn{8}{|c|}{ Fall Chinook Salmon } \\
\hline $3 / 11$ & 75 & 8.5 & 25.1 & 0 & 0 & 100.0 & 100.0 \\
\hline $3 / 30$ & 45 & 9.5 & 21.0 & 0 & 0 & 100.0 & 100.0 \\
\hline $4 / 1$ & 16 & 11.3 & 29.0 & 0 & 0 & 100.0 & 100.0 \\
\hline $4 / 2$ & 90 & 12.3 & 28.8 & 7 & 0 & 92.2 & 100.0 \\
\hline $4 / 9$ & 75 & 11.3 & 42.7 & 0 & 0 & 100.0 & 100.0 \\
\hline $4 / 16$ & 75 & 12.3 & 28.9 & 0 & 0 & 100.0 & 100.0 \\
\hline $4 / 23$ & 75 & 10.5 & 28.3 & 0 & 0 & 100.0 & 100.0 \\
\hline $4 / 29$ & 75 & 14.5 & 32.0 & 0 & 0 & 100.0 & 100.0 \\
\hline $5 / 10$ & 42 & 14.5 & 28.0 & 0 & 0 & 100.0 & 100.0 \\
\hline \multicolumn{8}{|c|}{ Subyearling Fall Chinook Salmon } \\
\hline $5 / 26$ & 50 & 18.0 & 24.5 & 0 & 0 & 100.0 & 100.0 \\
\hline $5 / 29$ & 50 & 18.3 & 26.5 & 0 & 0 & 100.0 & 100.0 \\
\hline $6 / 1$ & 75 & 17.0 & 23.0 & 0 & 0 & 100.0 & 100.0 \\
\hline $6 / 5$ & 50 & 20.5 & 26.4 & 0 & 0 & 100.0 & 100.0 \\
\hline $6 / 8$ & 75 & 19.0 & 23.0 & 0 & 0 & 100.0 & 100.0 \\
\hline $6 / 16$ & 70 & 20.5 & 23.0 & 0 & 0 & 100.0 & 100.0 \\
\hline
\end{tabular}


Table 5. Continued.

\begin{tabular}{|c|c|c|c|c|c|c|c|}
\hline $\begin{array}{l}\text { Mark } \\
\text { date }\end{array}$ & $\begin{array}{c}\text { Number } \\
\text { held }\end{array}$ & $\begin{array}{c}\text { Mean } \\
\text { temperature }^{a} \\
\end{array}$ & $\begin{array}{c}\text { Hours } \\
\text { held }\end{array}$ & $\begin{array}{c}\text { Number } \\
\text { mortalities } \\
\end{array}$ & $\begin{array}{c}\text { Number of } \\
\text { lost tags }\end{array}$ & $\begin{array}{c}\text { Percent } \\
\text { survival }^{b}\end{array}$ & $\begin{array}{c}\text { Percent tag } \\
\text { retention }\end{array}$ \\
\hline \multicolumn{8}{|c|}{ Summer Steelhead } \\
\hline $4 / 8$ & 75 & 10.0 & 25.0 & 0 & 0 & 100.0 & 100.0 \\
\hline $5 / 3$ & 49 & 16.5 & 31.5 & 0 & 0 & 100.0 & 100.0 \\
\hline $5 / 6$ & 49 & 15.5 & 27.5 & 0 & 0 & 100.0 & 100.0 \\
\hline $5 / 11$ & 50 & 14.5 & 26.0 & 0 & 0 & 100.0 & 100.0 \\
\hline $5 / 14$ & 50 & 17.0 & 24.5 & 4 & 0 & 92.0 & 100.0 \\
\hline $5 / 17$ & 50 & 19.0 & 24.8 & 0 & 0 & 100.0 & 100.0 \\
\hline $5 / 20$ & 49 & 20.5 & 25.5 & 2 & 0 & 95.9 & 100.0 \\
\hline $5 / 26$ & 42 & 18.0 & 30.5 & 0 & 0 & 100.0 & 100.0 \\
\hline $6 / 3$ & 69 & 19.0 & 23.8 & 0 & 0 & 100.0 & 100.0 \\
\hline \multicolumn{8}{|c|}{$\begin{array}{c}\text { Natural } \\
\text { Chinook Salmon }\end{array}$} \\
\hline $6 / 22$ & 69 & 22.1 & 29.8 & 10 & 0 & 85.5 & 100.0 \\
\hline $7 / 4$ & 65 & 18.5 & 29.0 & 0 & 0 & 100.0 & 100.0 \\
\hline $7 / 7$ & 75 & 21.0 & 30.5 & 4 & 0 & 94.7 & 100.0 \\
\hline \multicolumn{8}{|c|}{ Summer Steelhead } \\
\hline $5 / 17$ & 30 & 18.5 & 30.1 & 0 & 0 & 100.0 & 100.0 \\
\hline $5 / 19$ & 70 & 19.5 & 31.3 & 8 & 1 & 88.6 & 98.6 \\
\hline
\end{tabular}


Table 6. Trap efficiency releases and detections of hatchery and natural juvenile salmonids, mean travel times and trap efficiency estimates, West Extension Canal (RM 3.7), March - July 2000 .

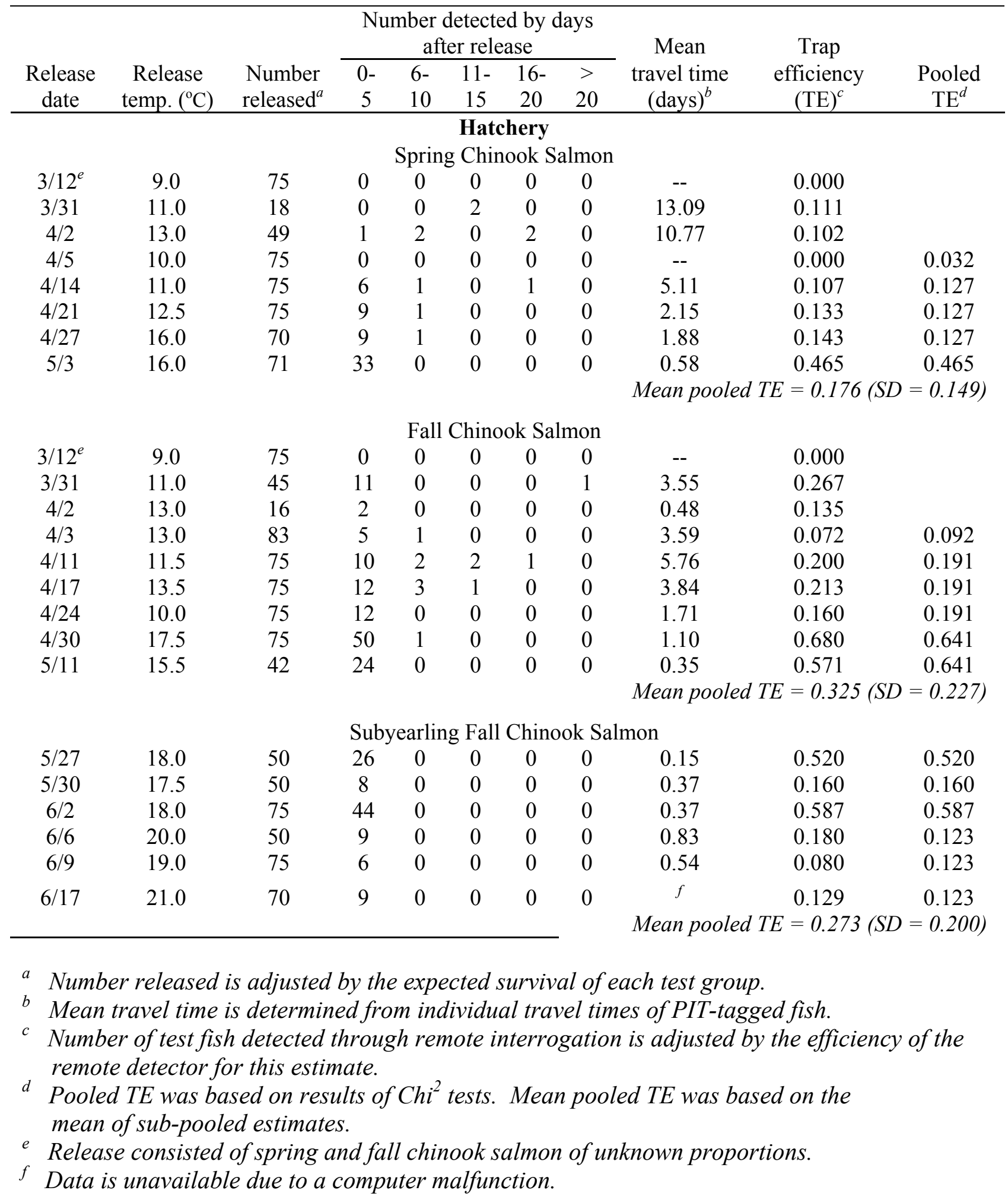


Table 6. Continued.

\begin{tabular}{|c|c|c|c|c|c|c|c|c|c|c|}
\hline \multirow[b]{2}{*}{$\begin{array}{l}\text { Release } \\
\text { date }\end{array}$} & \multirow[b]{2}{*}{$\begin{array}{l}\text { Release } \\
\text { temp. }\left({ }^{\circ} \mathrm{C}\right)\end{array}$} & \multirow[b]{2}{*}{$\begin{array}{l}\text { Number } \\
\text { released }^{a}\end{array}$} & \multicolumn{5}{|c|}{$\begin{array}{c}\text { Number detected by days } \\
\text { after release }\end{array}$} & \multirow{2}{*}{$\begin{array}{c}\text { Mean } \\
\text { travel time } \\
\text { (days) }^{b}\end{array}$} & \multirow{2}{*}{$\begin{array}{c}\text { Trap } \\
\text { efficiency } \\
(\mathrm{TE})^{c}\end{array}$} & \multirow[b]{2}{*}{$\begin{array}{l}\text { Pooled } \\
\mathrm{TE}^{d}\end{array}$} \\
\hline & & & $\begin{array}{l}0- \\
5\end{array}$ & $\begin{array}{l}6- \\
10 \\
\end{array}$ & $\begin{array}{l}11- \\
15\end{array}$ & $\begin{array}{l}16- \\
20\end{array}$ & $\begin{array}{c}> \\
20\end{array}$ & & & \\
\hline \multicolumn{11}{|c|}{ Summer Steelhead } \\
\hline $4 / 9$ & 11.0 & 75 & 29 & 0 & 0 & 0 & 2 & 2.24 & 0.413 & 0.285 \\
\hline $5 / 4$ & 17.0 & 49 & 10 & 0 & 0 & 0 & 0 & 0.59 & 0.204 & 0.285 \\
\hline $5 / 7$ & 16.0 & 49 & 6 & 1 & 1 & 0 & 0 & 3.67 & 0.163 & 0.285 \\
\hline $5 / 12$ & 15.0 & 50 & 16 & 0 & 0 & 0 & 0 & 0.47 & 0.320 & 0.285 \\
\hline $5 / 15$ & 18.0 & 42 & 13 & 1 & 0 & 0 & 0 & 1.17 & 0.331 & 0.285 \\
\hline $5 / 18$ & 19.0 & 50 & 11 & 0 & 0 & 0 & 0 & 0.75 & 0.220 & 0.285 \\
\hline $5 / 21$ & 21.0 & 45 & 5 & 0 & 0 & 0 & 0 & 0.38 & 0.111 & 0.092 \\
\hline $5 / 27$ & 18.0 & 42 & 2 & 1 & 0 & 0 & 0 & 4.04 & 0.071 & 0.092 \\
\hline \multirow[t]{2}{*}{$6 / 4$} & 20.0 & 69 & 17 & 1 & 0 & 0 & 0 & 1.24 & 0.261 & 0.261 \\
\hline & & & & & & & & \multicolumn{3}{|c|}{ Mean pooled $T E=0.240(S D=0.079)$} \\
\hline \multicolumn{11}{|c|}{$\begin{array}{l}\text { Natural } \\
\text { Chinook Salmon }\end{array}$} \\
\hline $6 / 23$ & 21.9 & 49 & 5 & 0 & 0 & 0 & 0 & 1.30 & 0.103 & 0.103 \\
\hline $7 / 5$ & 19.0 & 65 & 20 & 0 & 0 & 0 & 0 & 1.91 & 0.308 & 0.325 \\
\hline $7 / 8$ & 21.0 & 67 & 23 & 0 & 0 & 0 & 0 & 1.59 & 0.342 & 0.325 \\
\hline \multicolumn{11}{|c|}{ Mean pooled $T E=0.251(S D=0.105)$} \\
\hline \multicolumn{11}{|c|}{ Summer Steelhead } \\
\hline $5 / 18$ & 19.0 & 30 & 8 & 0 & 0 & 0 & 0 & 0.88 & 0.267 & 0.325 \\
\hline $5 / 20$ & 18.0 & 61 & 18 & 0 & 1 & 0 & 0 & 1.33 & 0.358 & 0.325 \\
\hline \multicolumn{11}{|c|}{ Mean pooled $T E=0.325(S D=0.000)$} \\
\hline
\end{tabular}


Table 7. Actual and adjusted collection of hatchery and natural juvenile salmonids at RM 1.2 and RM 3.7, Umatilla River, October 1999 - September 2000.

\begin{tabular}{|c|c|c|c|c|c|c|}
\hline $\begin{array}{l}\text { Site, } \\
\text { Species }^{a}\end{array}$ & Age & $\begin{array}{l}\text { Number } \\
\text { sampled }\end{array}$ & $\begin{array}{c}\text { Adjusted } \\
\text { number } \\
\text { collected }^{b}\end{array}$ & $\begin{array}{l}\text { Number } \\
\text { released }\end{array}$ & $\begin{array}{c}\text { Release } \\
\text { dates }^{c}\end{array}$ & $\begin{array}{c}\text { Percent } \\
\text { recapture }^{d}\end{array}$ \\
\hline \multicolumn{7}{|c|}{ Rotary - Screw Trap at RM $1.2(10 / 01 / 99$ - 3/06/00) } \\
\hline HSTS & $0+$ & 186 & 189 & 9,878 & $11 / 29 / 99$ & 1.91 \\
\hline $\mathrm{NCH}$ & $1+$ & 7 & 7 & -- & -- & -- \\
\hline NSTS & $1-2+$ & 3 & 3 & -- & -- & -- \\
\hline \multicolumn{7}{|c|}{ West Extension Canal at RM 3.7 (3/06/00 - 9/30/00) } \\
\hline $\mathrm{HCH}$ & $1+$ & 1,237 & 7,727 & 266,799 & $\begin{array}{c}3 / 6-3 / 9,4 / 6-4 / 12 \\
\& 4 / 6-4 / 13\end{array}$ & 0.46 \\
\hline $\mathrm{HCHS}$ & $1+$ & 2,950 & 24,400 & 816,184 & $3 / 6-3 / 9 \& 4 / 6-4 / 12$ & 0.36 \\
\hline $\mathrm{HCHF}$ & $1+$ & 3,036 & 28,348 & 469,756 & $3 / 6-3 / 9 \& 4 / 6-4 / 13$ & 0.65 \\
\hline $\mathrm{HCHF}$ & $0+$ & 6,659 & 7,045 & $3,020,519$ & $5 / 23 \& 5 / 24$ & 0.22 \\
\hline $\mathrm{HCOH}^{e}$ & $1+$ & 798 & 2,012 & 78,860 & $\begin{array}{c}3 / 8-3 / 15 \& 4 / 21- \\
4 / 28\end{array}$ & 1.01 \\
\hline HSTS & $1+$ & 893 & 2,748 & 153,738 & $\begin{array}{c}3 / 30-4 / 5,4 / 3-4 / 12 \\
\& 4 / 24-4 / 28\end{array}$ & 0.58 \\
\hline $\mathrm{NCH}$ & $0-1+$ & 3,580 & 4,621 & -- & -- & -- \\
\hline NSTS & $0-3+$ & 620 & 1,497 & -- & -- & -- \\
\hline $\mathrm{UCOH}^{f}$ & $0-1+$ & 15,027 & 31,131 & -- & -- & -- \\
\hline
\end{tabular}

${ }^{a}$ HSTS $=$ hatchery summer steelhead, $N C H=$ natural chinook salmon, $N C O H=$ natural coho salmon, NSTS = natural summer steelhead, $\mathrm{HCH}=$ hatchery chinook salmon of unknown origin, HCHS = hatchery spring chinook salmon, $H C H F=$ hatchery fall chinook salmon, $\mathrm{HCOH}=$ hatchery coho salmon, and $\mathrm{UCOH}=$ coho salmon of unknown origin.

$b$ Adjusted number collected is number sampled adjusted by time not sampled at RST and by sample rate at West Extension Canal only during sampling periods.

${ }^{c}$ Release date ranges begin with volitional and end with forced release day.

${ }^{d}$ Percent recapture is based on adjusted number collected for rotary-screw trap and on number sampled for West Extension Canal.

e Hatchery coho salmon were identified by an adipose-fin clip.

$f$ Unknown coho salmon consist of unmarked natural and hatchery fish. 
Table 8. Scale samples from hatchery and natural salmonids collected at RM 1.2 and RM 3.7 on the Umatilla River, March - September 2000.

\begin{tabular}{|c|c|c|c|c|}
\hline \multirow[b]{2}{*}{ Species $^{a}$} & \multirow[b]{2}{*}{ Number } & \multicolumn{2}{|c|}{ Fork length $(\mathrm{mm})$} & \multirow[b]{2}{*}{ Dates collected } \\
\hline & & Min & Max & \\
\hline \multicolumn{5}{|c|}{ Juvenile } \\
\hline $\mathrm{HCH}$ & 1 & 220 & 220 & $9 / 26$ \\
\hline HCHS & 2 & 216 & 245 & $7 / 12$ \\
\hline $\mathrm{HCOH}^{b}$ & 7 & 126 & 138 & $5 / 15-5 / 18$ \\
\hline $\mathrm{NCH}$ & 4 & 59 & 110 & $5 / 21-8 / 16$ \\
\hline NSTS & 106 & 120 & 305 & $3 / 11-7 / 25$ \\
\hline $\mathrm{UCOH}$ & 57 & 62 & 173 & $5 / 18-7 / 6$ \\
\hline \multicolumn{5}{|c|}{ Adult } \\
\hline NSTS & $1^{c}$ & 581 & 581 & $4 / 11$ \\
\hline
\end{tabular}

a $\mathrm{HCH}=$ hatchery chinook salmon of unknown race, HCHS = hatchery spring chinook salmon, $\mathrm{HCOH}=$ hatchery coho salmon, $\mathrm{NCH}=$ natural chinook salmon, NSTS = natural summer steelhead, and $\mathrm{UCOH}=$ coho salmon of unknown origin.

$b$ Hatchery coho salmon were identified by an adipose-fin clip.

c Post-spawn male. 
Table 9. Migration parameters of PIT-tagged hatchery, reach survival test, and natural juvenile salmonids detected at West Extension Canal (RM 3.7), Umatilla River, March - September 2000 .

\begin{tabular}{|c|c|c|c|c|c|c|c|c|c|}
\hline \multirow{3}{*}{$\begin{array}{l}\text { Hatchery, } \\
\text { rearing }\end{array}$} & & & \multicolumn{6}{|c|}{ Detection at lower river } & \multirow{3}{*}{$\begin{array}{l}\text { Median } \\
\text { travel } \\
\text { speed } \\
(\mathrm{mi} / \mathrm{d})^{d}\end{array}$} \\
\hline & \multicolumn{2}{|c|}{ Release } & \multirow[b]{2}{*}{$\mathrm{N}$} & \multirow{2}{*}{$\begin{array}{l}\text { First } \\
\text { (date) }\end{array}$} & \multirow{2}{*}{$\begin{array}{c}\text { Median } \\
\text { (date) }\end{array}$} & \multirow{2}{*}{$\begin{array}{c}\text { Last } \\
\text { (date) }\end{array}$} & \multirow{2}{*}{$\begin{array}{c}\text { Peak } \\
(\text { date })^{b}\end{array}$} & \multirow{2}{*}{$\begin{array}{c}\text { Duration } \\
\left(_{\text {days })^{c}}\right.\end{array}$} & \\
\hline & Date $^{a}$ & $\mathrm{RM}$ & & & & & & & \\
\hline \multicolumn{10}{|c|}{$\begin{array}{c}\text { Hatchery } \\
\text { Spring Chinook Salmon }\end{array}$} \\
\hline \multicolumn{10}{|c|}{ Umatilla Fish Hatchery } \\
\hline Standard $^{e}$ & $3 / 9$ & 80 & 10 & $3 / 8$ & $4 / 1$ & $4 / 28$ & - & 52 & 3.2 \\
\hline Standard & $3 / 9$ & 80 & 5 & $3 / 10$ & $4 / 13$ & $4 / 26$ & - & 48 & 2.2 \\
\hline Oxygenated & $3 / 9$ & 80 & 10 & $3 / 11$ & $4 / 13$ & $4 / 28$ & - & 49 & 2.2 \\
\hline \multicolumn{10}{|c|}{ Little White Salmon Hatchery } \\
\hline Standard & $3 / 9$ & 80 & 6 & $4 / 10$ & $4 / 19$ & $4 / 23$ & - & 14 & 1.9 \\
\hline Standard & $4 / 12$ & 80 & 23 & $4 / 14$ & $4 / 28$ & $5 / 16$ & $4 / 29$ & 33 & 4.9 \\
\hline \multicolumn{10}{|c|}{ Carson Fish Hatchery } \\
\hline Standard & $4 / 12$ & 80 & 60 & $4 / 10$ & $4 / 29$ & $5 / 5$ & $4 / 29+30$ & 26 & 4.6 \\
\hline \multicolumn{10}{|c|}{ Fall Chinook Salmon } \\
\hline \multicolumn{10}{|c|}{ Bonneville Fish Hatchery } \\
\hline Standard & $3 / 9$ & 73.5 & 10 & $3 / 12$ & $4 / 5$ & $4 / 18$ & - & 38 & 2.5 \\
\hline Standard & $4 / 13$ & 73.5 & 57 & $4 / 11$ & $4 / 29$ & $5 / 5$ & $4 / 28+5 / 2$ & 25 & 4.5 \\
\hline \multicolumn{10}{|c|}{ Subyearling Fall Chinook Salmon } \\
\hline \multicolumn{10}{|c|}{ Umatilla Fish Hatchery } \\
\hline 200K density & $5 / 23$ & 73.5 & 182 & $5 / 25$ & $5 / 25$ & $6 / 12$ & $5 / 25$ & 19 & 31.9 \\
\hline $300 \mathrm{~K}$ density & $5 / 23$ & 73.5 & 148 & $5 / 25$ & $5 / 25$ & $6 / 8$ & $5 / 25$ & 15 & 31.6 \\
\hline $400 \mathrm{~K}$ density & $5 / 23$ & 73.5 & 175 & $5 / 25$ & $5 / 25$ & $6 / 10$ & $5 / 25$ & 17 & 31.5 \\
\hline $200 \mathrm{~K}$ density & $5 / 24$ & 56 & 375 & $5 / 25$ & $5 / 26$ & $6 / 13$ & $5 / 26$ & 20 & 26.4 \\
\hline $300 \mathrm{~K}$ density & $5 / 24$ & 56 & 428 & $5 / 25$ & $5 / 26$ & $6 / 6$ & $5 / 26$ & 13 & 26.6 \\
\hline $400 \mathrm{~K}$ density & $5 / 24$ & 56 & 410 & $5 / 25$ & $5 / 26$ & $6 / 6$ & $5 / 26$ & 13 & 25.3 \\
\hline $200 \mathrm{~K}$ density $^{f}$ & $5 / 24$ & 56 & 245 & $5 / 25$ & $5 / 26$ & $6 / 9$ & $5 / 26$ & 16 & 24.2 \\
\hline \multicolumn{10}{|c|}{ 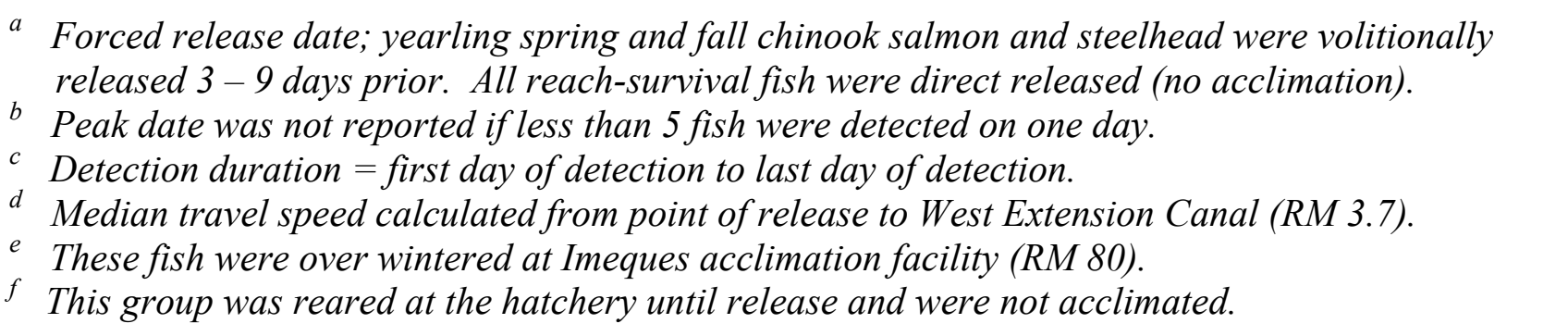 } \\
\hline
\end{tabular}


Table 9. Continued.

\begin{tabular}{|c|c|c|c|c|c|c|c|c|c|}
\hline \multirow{3}{*}{$\begin{array}{l}\text { Hatchery, } \\
\text { rearing }\end{array}$} & & & \multicolumn{6}{|c|}{ Detection at lower river } & \multirow{3}{*}{$\begin{array}{l}\text { Mediar } \\
\text { travel } \\
\text { speed } \\
(\mathrm{mi} / \mathrm{d})\end{array}$} \\
\hline & \multicolumn{2}{|c|}{ Release } & & First & \multirow{2}{*}{$\begin{array}{l}\text { Median } \\
\text { (date) }\end{array}$} & \multirow{2}{*}{$\begin{array}{c}\text { Last } \\
\text { (date) }\end{array}$} & \multirow{2}{*}{$\begin{array}{c}\text { Peak } \\
(\text { date })^{b}\end{array}$} & \multirow{2}{*}{$\begin{array}{l}\text { Duration } \\
\text { (days) }^{c}\end{array}$} & \\
\hline & Date $^{a}$ & RM & $\mathrm{N}$ & (date) & & & & & \\
\hline & & & & $\begin{array}{r}\mathbf{H}: \\
\text { Summ }\end{array}$ & $\begin{array}{l}\text { tchery } \\
\text { r Steelhe }\end{array}$ & & & & \\
\hline \multicolumn{10}{|c|}{ Umatilla Fish Hatchery } \\
\hline Large grade & $4 / 5$ & 64.5 & 36 & $4 / 7$ & $5 / 11$ & $5 / 26$ & $5 / 20$ & 50 & 1.4 \\
\hline Large grade & $4 / 12$ & $79^{g}$ & 20 & $4 / 16$ & $5 / 20$ & $6 / 2$ & $6 / 1$ & 48 & 1.6 \\
\hline Small grade & $4 / 28$ & 64.5 & 47 & $5 / 4$ & $5 / 21$ & $6 / 16$ & $5 / 20+6 / 1$ & 44 & 2.3 \\
\hline Small grade ${ }^{h}$ & $4 / 5$ & 64.5 & 40 & $4 / 9$ & $5 / 23$ & $6 / 8$ & $6 / 1$ & 61 & 1.4 \\
\hline Small grade ${ }^{h}$ & $4 / 12$ & $79^{g}$ & 19 & $5 / 17$ & $6 / 1$ & $6 / 19$ & $6 / 1$ & 34 & 1.6 \\
\hline \multicolumn{10}{|c|}{$\begin{array}{c}\text { Reach Survival } \\
\text { Spring Chinook Salmon }\end{array}$} \\
\hline \multicolumn{3}{|c|}{ Umatilla Fish Hatchery } & & & & & & & \\
\hline Oregon & $3 / 7$ & 9 & 3 & $3 / 8$ & - & $3 / 9$ & - & 2 & 5.3 \\
\hline Oregon & $3 / 8$ & 9 & 7 & $3 / 8$ & - & $3 / 17$ & - & 6 & 5.3 \\
\hline Oregon & $3 / 9$ & 9 & 1 & $3 / 10$ & - & $3 / 10$ & - & 1 & 5.3 \\
\hline Combined & & & 11 & & $3 / 9$ & & $3 / 9$ & 10 & 5.3 \\
\hline Oregon & $3 / 7$ & 27 & 2 & $3 / 8$ & - & $3 / 9$ & - & 2 & 15.5 \\
\hline Oregon & $3 / 8$ & 27 & 5 & $3 / 9$ & - & $3 / 10$ & - & 2 & 23.3 \\
\hline Oregon & $3 / 9$ & 27 & 3 & $3 / 10$ & - & $3 / 11$ & - & 2 & 11.7 \\
\hline Combined & & & 10 & & $3 / 9$ & & $3 / 9$ & 4 & 15.5 \\
\hline Oregon & $3 / 7$ & 80 & 5 & $3 / 9$ & - & $3 / 29$ & - & 21 & 38.2 \\
\hline Oregon & $3 / 8$ & 80 & 2 & $3 / 10$ & - & $3 / 29$ & - & 20 & 6.9 \\
\hline Oregon & $3 / 9$ & 80 & 3 & $3 / 12$ & - & $3 / 24$ & - & 13 & 10.9 \\
\hline Combined & & & 10 & & $3 / 11$ & & $3 / 9$ & 21 & 30.5 \\
\hline
\end{tabular}

Subyearling Fall Chinook Salmon

Umatilla Fish Hatchery

Medium density $\quad 5 / 23$

Medium density $5 / 2$

Medium density $5 / 25$

Combined

$\begin{array}{cccccccc}9 & 71 & 5 / 24 & 5 / 24 & 5 / 26 & 5 / 24 & 3 & 5.4 \\ 9 & 46 & 5 / 25 & 5 / 25 & 5 / 26 & 5 / 25 & 3 & 5.6 \\ 9 & 60 & 5 / 25 & 5 / 26 & 5 / 27 & 5 / 26 & 3 & 8.6 \\ & 177 & & 5 / 25 & & 5 / 25 & 4 & 6.2\end{array}$

Medium density $5 / 23$

$\begin{array}{lll}27 & 39 & 5 / 25\end{array}$

$5 / 25$

$6 / 3$

$5 / 25$

10

11.9

Medium density $5 / 2$

Medium density $5 / 25$

27
27

$30 \quad 5 / 25 \quad 5 / 26$

$6 / 1$

$5 / 26$

8

$5 / 26$

13.8

Combined

$126 \quad 5 / 26$

$5 / 26$

3

18.6

${ }^{g}$ River mile 2 of Meacham Creek.

${ }^{h}$ Test releases of small-grade fish with large-grade fish at Minthorn and Bonifer acclimation ponds. 
Table 9. Continued.

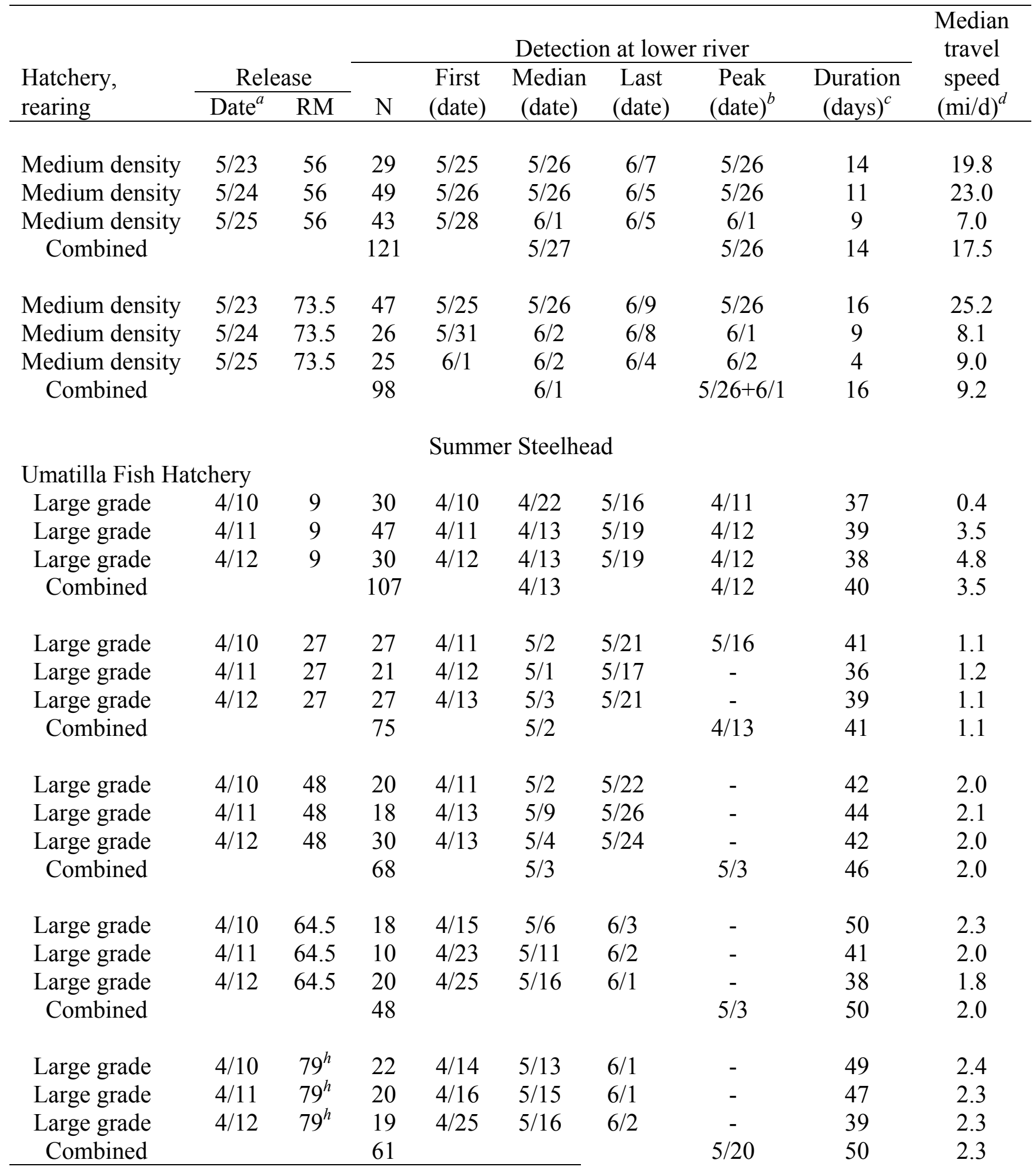


Table 9. Continued.

Med.

Detection at lower river travel

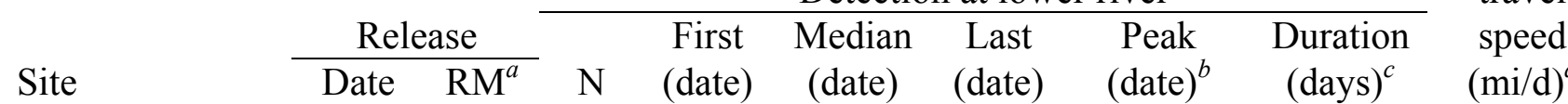

Site

Natural

Chinook Salmon

Umatilla River

$\begin{array}{lllllllll}12 / 14 & 80 & 1 & 5 / 1 & - & 5 / 1 & - & 1 & 0.55\end{array}$

Coho Salmon

Umatilla River

$\begin{array}{lllllllll}12 / 8 & 80 & 15 & 5 / 2 & 5 / 26 & 6 / 3 & - & 33 & 2.8\end{array}$
$5 / 16$

$\begin{array}{lllllllll}11 / 23 & 77 & 5 & 5 / 16 & 6 / 1 & 6 / 2 & - & 18 & 0.4\end{array}$

Buckaroo Creek

$12 / 27$

Minthorn

$\begin{array}{lllllllll}12 / 28 & 73 & 2 & 5 / 19 & - & 5 / 20 & - & 2 & 0.5\end{array}$

$\begin{array}{lllllllll}12 / 30 & 64.5 & 1 & 5 / 20 & - & 5 / 20 & - & 1 & 0.4\end{array}$

McKay Creek

$\begin{array}{lllllllll}12 / 3 & 51 & 13 & 4 / 19 & 5 / 7 & 6 / 1 & - & 44 & 0.3\end{array}$

Summer Steelhead

Umatilla River

$\begin{array}{lllllllll}\begin{array}{l}12 / 2- \\ 5 / 16\end{array} & 80 & 131 & 4 / 7 & 5 / 18 & 6 / 3 & 5 / 20 & 58 & 3.3\end{array}$

Squaw Creek

$\begin{array}{lllllllll}\begin{array}{c}11 / 23 \\ -4 / 6\end{array} & 77 & 10 & 4 / 16 & 5 / 24 & 6 / 2 & - & 48 & 0.5\end{array}$

Buckaroo Creek

$\begin{array}{lllllllll}12 / 28 & 73 & 1 & 4 / 9 & - & 4 / 9 & - & 1 & 0.7\end{array}$

Minthorn

$\begin{array}{lllllllll}12 / 30 & 64.5 & 2 & 5 / 1 & - & 5 / 21 & - & 21 & 0.5\end{array}$

Moonshine Creek

Cottonwood Creek

$12 / 29 \quad 67 \quad 0$

Birch Creek $^{i}$

$4 / 1 \quad 65 \quad 0$

McKay Creek

$\begin{array}{lllllllll}4 / 7-26 & 48 & 11 & 5 / 5 & 5 / 23 & 6 / 9 & - & 36 & 1.4\end{array}$

\begin{tabular}{lllllllll}
$\begin{array}{l}12 / 14- \\
15\end{array}$ & 51 & 7 & $5 / 11$ & $5 / 20$ & $5 / 25$ & - & 15 & 0.3 \\
\hline
\end{tabular}


Table 10. Summary of injuries and parasites on hatchery and natural juvenile salmonids collected at RM 3.7, Umatilla River, March - July 2000.

\begin{tabular}{|c|c|c|c|c|c|c|c|}
\hline \multirow[b]{3}{*}{ Species $^{b}$} & \multicolumn{7}{|c|}{ Condition $^{a}$} \\
\hline & \multicolumn{2}{|c|}{ Bird marks } & \multicolumn{2}{|c|}{ Injuries } & \multicolumn{2}{|c|}{ Parasites } & \multirow{2}{*}{$\begin{array}{c}\text { Total number } \\
\text { examined }\end{array}$} \\
\hline & Number & Percent $^{c}$ & Number & Percent & Number & Percent & \\
\hline & \multicolumn{7}{|c|}{ Hatchery } \\
\hline $\mathrm{CH}$ & 17 & 2.2 & 8 & 1.0 & 2 & 0.3 & 785 \\
\hline $\mathrm{CHS}$ & 71 & 4.8 & 16 & 1.1 & 7 & 0.5 & 1,475 \\
\hline $\mathrm{CHF}$ & 52 & 3.5 & 14 & 1.0 & 8 & 0.5 & 1,472 \\
\hline $\mathrm{CHF0}$ & 32 & 1.8 & 26 & 1.4 & 1 & $<0.1$ & 1,826 \\
\hline $\mathrm{COH}^{d}$ & 9 & 7.2 & 1 & 0.8 & 1 & 0.8 & 125 \\
\hline \multirow[t]{2}{*}{ STS } & 43 & 5.9 & 17 & 2.3 & 4 & 0.5 & 734 \\
\hline & \multicolumn{7}{|c|}{ Natural } \\
\hline $\mathrm{CH}^{e}$ & 18 & 0.7 & 28 & 1.2 & 60 & 2.5 & 2,430 \\
\hline $\mathrm{COH}^{f}$ & 183 & 5.1 & 49 & 1.4 & 40 & 1.1 & 3,596 \\
\hline STS & 28 & 4.7 & 18 & 3.0 & 35 & 5.8 & 600 \\
\hline
\end{tabular}

a Condition refers to the presence of bird marks, body injuries, and external parasites. Body injuries include damaged eyes, operculum, head, body, and fins and presence of fungus. Parasites include leeches and nematode metacercaria. Some fish with bird marks and parasites also had body injuries.

${ }^{b} \mathrm{CH}=$ spring and fall chinook salmon, CHS = spring chinook salmon, CHF = fall chinook salmon, $C H F O=$ subyearling fall chinook salmon, $C O H=$ coho salmon, STS = summer steelhead.

c Percent is based on all fish examined.

${ }^{d}$ Only coho salmon with an adipose fin clip were designated as hatchery origin.

e $\mathrm{CH}=$ natural chinook salmon includes yearling and subyearling age groups.

$f$ Unmarked hatchery coho salmon included. 
Table 11. Summary of scale loss and mortality of hatchery and natural juvenile salmonids collected RM 3.7, Umatilla River, March - July 2000.

\begin{tabular}{|c|c|c|c|c|c|c|c|c|}
\hline \multirow[b]{3}{*}{ Species $^{b}$} & \multicolumn{8}{|c|}{ Condition $^{a}$} \\
\hline & \multicolumn{2}{|c|}{ Good } & \multicolumn{2}{|c|}{ Partial } & \multicolumn{2}{|c|}{ Descaled } & \multicolumn{2}{|c|}{ Mortality $^{c}$} \\
\hline & Number & Percent & Number & Percent & Number & Percent & Numbe & Percent \\
\hline & \multicolumn{8}{|c|}{ Hatchery } \\
\hline $\mathrm{CH}$ & 726 & 92.6 & 53 & 6.8 & 5 & 0.6 & 0 & 0.0 \\
\hline CHS & 1,263 & 86.3 & 179 & 12.2 & 21 & 1.4 & 1 & $<0.1$ \\
\hline CHF & 1,333 & 90.6 & 127 & 8.6 & 12 & 0.8 & 0 & 0.0 \\
\hline CHF0 & 1,637 & 89.6 & 142 & 7.8 & 47 & 2.6 & 2 & $<0.1$ \\
\hline $\mathrm{COH}^{d}$ & 93 & 75.0 & 26 & 21.0 & 5 & 4.0 & 0 & 0.0 \\
\hline \multirow[t]{2}{*}{ STS } & 482 & 65.8 & 224 & 30.6 & 27 & 3.7 & 0 & 0.0 \\
\hline & \multicolumn{8}{|c|}{ Natural } \\
\hline $\mathrm{CH}^{e}$ & 2,213 & 91.1 & 163 & 6.7 & 53 & 2.2 & 6 & 0.2 \\
\hline $\mathrm{COH}^{f}$ & 2,873 & 80.0 & 608 & 16.9 & 108 & 3.0 & 4 & $<0.1$ \\
\hline STS & 501 & 83.8 & 85 & 14.2 & 12 & 2.0 & 1 & 0.2 \\
\hline
\end{tabular}

a Condition refers to the extent of scale loss on live fish captured and fish mortalities. Good $=$ scale loss $<3 \%$; Partial $=$ scale loss $>3 \%$ and $<20 \%$; Descaled $=$ scale loss $>20 \%$.

${ }^{b} \mathrm{CH}=$ spring and fall chinook salmon, $\mathrm{CHFO}=$ subyearling fall chinook salmon, $\mathrm{COH}=$ coho salmon, STS = summer steelhead.

$c$ Mortality does not include handling or trap-caused mortality.

${ }^{d}$ Only coho salmon with an adipose fin clip were designated as hatchery origin.

e $\mathrm{CH}=$ natural chinook salmon includes yearling and subyearling age groups.

$f$ Unmarked hatchery coho salmon included. 
Table 12. Release and recapture of juvenile Pacific lampreys (macrophthalmia) and trap efficiency estimates at the rotary-screw trap (RM 1.2), Umatilla River, November 1999 February 2000.

\begin{tabular}{ccccc}
\hline Date & $\begin{array}{c}\text { Number } \\
\text { released }\end{array}$ & $\begin{array}{c}\text { Running total } \\
\text { of number } \\
\text { released }\end{array}$ & $\begin{array}{c}\text { Number } \\
\text { recaptured }\end{array}$ & Trap efficiency \\
\hline $11 / 30 / 99$ & 1 & 1 & 0 & 0 \\
$12 / 01 / 99$ & 1 & 2 & 0 & 0 \\
$12 / 05 / 99$ & 18 & 20 & 0 & 0 \\
$12 / 07 / 99$ & 1 & 21 & 0 & 0 \\
$12 / 19 / 99$ & 67 & 88 & 0 & 0 \\
$12 / 22 / 99$ & 4 & 92 & 0 & 0 \\
$12 / 28 / 99$ & -- & 92 & 1 & 0.011 \\
$1 / 08 / 00$ & 1 & 93 & 0 & 0 \\
$2 / 07 / 00$ & 1 & 94 & 0 & 0 \\
$2 / 09 / 00$ & 1 & 95 & 0 & 0 \\
$2 / 16 / 00$ & 29 & 124 & 0 & 0 \\
$2 / 18 / 00$ & 5 & 129 & 0 & 0 \\
Overall & 129 & 129 & 1 & 0.008 \\
\hline
\end{tabular}


Table 13. Detection, abundance, and survival of PIT-tagged production fish released into the upper Umatilla River and detected in the lower river, March - June 2000.

\begin{tabular}{|c|c|c|c|c|c|c|c|c|}
\hline Hatchery $^{a}$ & Pond & $\begin{array}{c}\text { Volitional } \\
\text { release } \\
\text { date }\end{array}$ & $\begin{array}{c}\text { Release } \\
\text { site }\end{array}$ & $\begin{array}{l}\text { Release } \\
\text { number }\end{array}$ & $\begin{array}{l}\text { Detection } \\
\text { at RM } 3.7\end{array}$ & $\begin{array}{c}\text { Percent } \\
\text { detection }\end{array}$ & $\begin{array}{l}\text { Abun- } \\
\text { dance }^{b}\end{array}$ & $\begin{array}{c}\text { Percent } \\
\text { survival } \\
(95 \% \text { C.I. })\end{array}$ \\
\hline \multicolumn{9}{|c|}{ Soring Chinook Salmon } \\
\hline UFH & $\mathrm{O} 4 \mathrm{~A}$ & $3 / 6 / 00$ & RM 80 & 266 & 5 & 1.9 & 109 & $41.0( \pm 69.9)$ \\
\hline UFH & O4B & $3 / 6 / 00$ & RM 80 & 263 & 5 & 1.9 & 116 & $44.1( \pm 73.0)$ \\
\hline UFH & $\mathrm{O} 5 \mathrm{~A}$ & $3 / 6 / 00$ & RM 80 & 291 & 3 & 1.0 & 31 & $11.8( \pm 14.8)$ \\
\hline UFH & O5B & $3 / 6 / 00$ & RM 80 & 279 & 2 & 0.7 & 39 & $14.0( \pm 38.6)$ \\
\hline UFH & M1A & $3 / 6 / 00$ & RM 80 & 253 & 6 & 2.4 & 93 & $36.8( \pm 65.2)$ \\
\hline UFH & M1B & $3 / 6 / 00$ & RM 80 & 249 & 2 & 0.8 & 39 & $15.7( \pm 38.6)$ \\
\hline UFH & $\mathrm{M} 1 \mathrm{C}$ & $3 / 6 / 00$ & RM 80 & 263 & 2 & 0.8 & 39 & $14.8( \pm 38.6)$ \\
\hline LWSH & LWS-1 & $3 / 6 / 0$ & RM 80 & 297 & 6 & 2.0 & 54 & $18.2( \pm 18.2)$ \\
\hline LWSH & LWS-2 & $4 / 6 / 00$ & RM 80 & 270 & 23 & 8.5 & 126 & $46.7( \pm 24.4)$ \\
\hline Carson & Carson & $4 / 6 / 00$ & RM 80 & 297 & 60 & 20.2 & 300 & $101.0( \pm 38.0)$ \\
\hline $\begin{array}{c}\text { Overall } \\
95 \% \text { C. I. }\end{array}$ & & & & & & & $\begin{array}{l}946 \\
(20.6\end{array}$ & $\begin{array}{c}34.7 \\
-48.8 \%)\end{array}$ \\
\hline \multicolumn{9}{|c|}{ Yearling Fall Chinook Salmon } \\
\hline $\mathrm{BFH}$ & $\mathrm{BFH}$ & $3 / 6 / 00$ & RM 73 & 286 & 10 & 3.7 & 80 & $28.0( \pm 20.3)$ \\
\hline BFH & $\mathrm{BFH}$ & $4 / 6 / 00$ & RM 73 & 289 & 57 & 19.7 & 157 & $54.3( \pm 15.9)$ \\
\hline $\begin{array}{l}\text { Overall } \\
95 \% \text { C.I. }\end{array}$ & & & & & & & $\begin{array}{l}237 \\
(28.3\end{array}$ & $\begin{array}{c}41.2 \\
-54.1 \%)\end{array}$ \\
\hline \multicolumn{9}{|c|}{ Subvearling Fall Chinook Salmon } \\
\hline UFH & M1A & $5 / 24 / 00$ & RM 73 & 596 & 218 & 36.6 & 423 & $71.0( \pm 21.0)$ \\
\hline UFH & M1B & $5 / 24 / 00$ & RM 73 & 584 & 210 & 36.0 & 419 & $71.7( \pm 19.9)$ \\
\hline UFH & $\mathrm{M} 2 \mathrm{~A}$ & $5 / 24 / 00$ & RM 73 & 570 & 216 & 37.9 & 435 & $76.3( \pm 19.6)$ \\
\hline UFH & M2B & $5 / 24 / 00$ & RM 73 & 594 & 194 & 32.7 & 385 & $64.8( \pm 18.5)$ \\
\hline UFH & M3A & $5 / 24 / 00$ & RM 73 & 594 & 180 & 30.3 & 353 & $59.4( \pm 15.8)$ \\
\hline UFH & M3B & $5 / 24 / 99$ & RM 73 & 588 & 195 & 33.2 & 394 & $67.0( \pm 18.2)$ \\
\hline UFH & $\mathrm{M} 1 \mathrm{C}$ & $5 / 23 / 00$ & RM 56 & 587 & 148 & 25.2 & 299 & $50.9( \pm 14.1)$ \\
\hline UFH & $\mathrm{M} 2 \mathrm{C}$ & $5 / 23 / 00$ & RM 56 & 594 & 175 & 29.5 & 347 & $58.4( \pm 15.8)$ \\
\hline UFH & $\mathrm{M} 3 \mathrm{C}$ & $5 / 23 / 00$ & RM 56 & 588 & 182 & 31.0 & 364 & $61.9( \pm 16.2)$ \\
\hline $\begin{array}{l}\text { Overall } \\
95 \% \text { C.I. }\end{array}$ & & & & & & & $\begin{array}{l}3419 \\
\quad(58.7\end{array}$ & $\begin{array}{r}64.6 \\
-70.5 \%)\end{array}$ \\
\hline \multicolumn{9}{|c|}{ Summer Steelhead } \\
\hline UFH & M8B & $4 / 3 / 00$ & RM 79 & 252 & 20 & 7.9 & 118 & $46.8( \pm 43.3)$ \\
\hline UFH & $\mathrm{M} 8 \mathrm{C}$ & $3 / 30 / 00$ & RM 65 & 233 & 36 & 15.5 & 178 & $76.4( \pm 49.4)$ \\
\hline UFH & M8A & $4 / 24 / 00$ & RM 65 & 565 & 47 & 8.3 & 296 & $52.4( \pm 32.7)$ \\
\hline $\begin{array}{l}\text { Overall } \\
95 \% \text { C.I. }\end{array}$ & & & & & & & $\begin{array}{l}592 \\
(33.3\end{array}$ & $\begin{array}{r}56.4 \\
-79.5 \%)\end{array}$ \\
\hline
\end{tabular}


Table 14. Detection, abundance, and survival of PIT-tagged natural fish released into the upper Umatilla River and tributaries and detected in the lower river, March - June 2000.

\begin{tabular}{|c|c|c|c|c|c|}
\hline Release Site $^{a}$ & $\begin{array}{l}\text { Number } \\
\text { released }\end{array}$ & $\begin{array}{l}\text { Number } \\
\text { detected }\end{array}$ & $\begin{array}{c}\text { Percent } \\
\text { detection }\end{array}$ & $\begin{array}{l}\text { Abun- } \\
\text { dance }^{b}\end{array}$ & $\begin{array}{l}\text { Percent } \\
\text { survival }\end{array}$ \\
\hline \multicolumn{6}{|c|}{ Spring Chinook Salmon } \\
\hline Umatilla River & 56 & 1 & 1.8 & 2 & $5.4( \pm 9.3)$ \\
\hline Minthorn & 1 & 0 & 0.0 & 0 & 0.0 \\
\hline Total & 57 & 1 & 1.8 & 2 & $5.4( \pm 9.3)$ \\
\hline \multicolumn{6}{|c|}{ Coho Salmon } \\
\hline Umatilla River & 76 & 15 & 19.7 & 29 & $38.2( \pm 14.6)$ \\
\hline Squaw Creek & 47 & 5 & 10.6 & 11 & $23.4( \pm 13.2)$ \\
\hline Buckaroo Creek & 30 & 2 & 6.7 & 4 & $13.3( \pm 11.3)$ \\
\hline Minthorn & 17 & 1 & 5.9 & 2 & $11.8( \pm 16.3)$ \\
\hline McKay Creek & 365 & 13 & 3.6 & 27 & $7.4( \pm 3.6)$ \\
\hline Total & 535 & 36 & 6.7 & 73 & $13.6( \pm 3.5)$ \\
\hline \multicolumn{6}{|c|}{ Summer Steelhead } \\
\hline Umatilla River & 907 & 131 & 14.4 & 723 & $79.7( \pm 49.2)$ \\
\hline Squaw Creek & 103 & 10 & 9.7 & 64 & $62.1( \pm 75.7)$ \\
\hline Buckaroo Creek & 54 & 1 & 1.9 & 4 & $7.4( \pm 13.0)$ \\
\hline Minthorn & 19 & 2 & 10.5 & 15 & $78.9( \pm 158)$ \\
\hline Moonshine Creek & 16 & 0 & 0.0 & 0 & 0.0 \\
\hline Cottonwood Creek & 21 & 0 & 0.0 & 0 & 0.0 \\
\hline McKay Creek & 119 & 7 & 5.9 & 48 & $40.3( \pm 63.9)$ \\
\hline East Fork Birch Cr & 163 & 8 & 4.9 & 59 & $36.2( \pm 48.5)$ \\
\hline West Fork Birch Cr & 94 & 1 & 1.1 & 4 & $4.3( \pm 6.9)$ \\
\hline Pearson Creek & 58 & 2 & 3.4 & 16 & $27.6( \pm 53.4)$ \\
\hline Total & 1,554 & 162 & 10.4 & 933 & $60.0( \pm 30.1)$ \\
\hline
\end{tabular}

a Umatilla River $=$ RM 80, Squaw Creek $=$ RM 77, Buckaroo Creek $=$ RM 73, Minthorn $=R M$ 64.5, McKay Creek = RM 51, Birch Creek = RM 48, East Fork Birch Creek $=$ RM 16 of Birch Crk., West Fork Birch Creek = RM 16 of Birch Crk., Pearson Creek = RM 11 of Birch Crk.

b See Methods for abundance estimation method. 
Table 16. Mean length, tag loss, and holding mortality for tagged fish used in reachspecific survival tests, and tag consumption by fish during holding, Umatilla River, March - July 2000.

\begin{tabular}{|c|c|c|c|c|c|}
\hline Species $^{a}$ & $\begin{array}{c}\text { Release } \\
\text { site }\end{array}$ & $\begin{array}{c}\text { Mean } \\
\text { FL }(\mathrm{SE})^{b}\end{array}$ & $\begin{array}{l}\text { Tag } \\
\text { loss }\end{array}$ & $\begin{array}{l}\text { Tagging } \\
\text { mortality }\end{array}$ & $\begin{array}{c}\text { Tag } \\
\text { consumption }\end{array}$ \\
\hline CHS & RM 80 & $156.5(2.8)$ & & & \\
\hline $\mathrm{CHS}$ & RM 27 & $155.4(0.6)$ & & & \\
\hline $\mathrm{CHS}$ & RM 9 & $155.6(2.0)$ & & & \\
\hline Total & & & 255 & 120 & 0 \\
\hline CHF0 & RM 74 & $98.0(1.2)$ & & & \\
\hline CHF0 & RM 56 & $98.1(0.8)$ & & & \\
\hline CHF0 & RM 27 & $97.5(0.5)$ & & & \\
\hline CHF0 & RM 9 & $96.7(2.1)$ & & & \\
\hline CHF0 & RM 0 & $96.9(0.3)$ & & & \\
\hline Total & & & 22 & 23 & 0 \\
\hline $\mathrm{STS}^{c}$ & RM 79 & $189.4(2.8)$ & & & \\
\hline $\mathrm{STS}^{c}$ & RM 65 & $190.8(0.5)$ & & & \\
\hline $\mathrm{STS}^{c}$ & RM 48 & $190.2(1.9)$ & & & \\
\hline $\mathrm{STS}^{c}$ & RM 27 & $189.4(6.0)$ & & & \\
\hline $\mathrm{STS}^{c}$ & RM 9 & $188.6(1.7)$ & & & \\
\hline Total & & & 101 & 5 & 16 \\
\hline
\end{tabular}

a $C H S=$ spring chinook salmon, CHFO = subyearling fall chinook salmon, STS = summer steelhead.

$b$ Fork length measured at time of tagging. Standard error of the mean in parentheses. 
Table 17. Detection, abundance, and survival of PIT-tagged fish released for reachspecific survival tests and interrogated in the lower Umatilla River (RM 3.7), March July 2000. Means with the same letter are not significantly different.

\begin{tabular}{|c|c|c|c|c|c|c|c|}
\hline Species $^{a}$ & $\begin{array}{c}\text { Release } \\
\text { dates }\end{array}$ & $\begin{array}{c}\text { Release } \\
\text { site }\end{array}$ & $\begin{array}{l}\text { Release } \\
\text { number }\end{array}$ & $\begin{array}{l}\text { Number } \\
\text { detected }\end{array}$ & $\begin{array}{l}\text { Mean \% } \\
\text { detection } \\
\text { (95\% C.I.) }\end{array}$ & $\begin{array}{l}\text { Abun- } \\
\text { dance }^{b}\end{array}$ & $\begin{array}{l}\text { Mean } \\
\text { survival } \\
\text { (95\% C.I.) }\end{array}$ \\
\hline CHS & $3 / 7-3 / 9$ & RM 80 & 1,002 & 10 & $1.0( \pm 0.4)$ & 464 & $46.3( \pm 19.4)_{\mathrm{A}}$ \\
\hline CHS & $3 / 7-3 / 9$ & RM 27 & 1,000 & 10 & $1.0( \pm 0.4)$ & 464 & $46.4( \pm 19.5)_{\mathrm{A}}$ \\
\hline CHS & $3 / 7-3 / 9$ & RM 9 & 777 & 11 & $1.3( \pm 0.9)$ & 510 & $61.1( \pm 42.1)_{\mathrm{A}}$ \\
\hline CHF0 & $5 / 23-5 / 25$ & RM 74 & 447 & 98 & $21.9( \pm 7.6)$ & 215 & $48.0( \pm 14.9)_{\mathrm{A}}$ \\
\hline CHF0 & $5 / 23-5 / 25$ & RM 56 & 448 & 121 & $27.0( \pm 6.4)$ & 256 & $57.2( \pm 12.7)_{\mathrm{A}}$ \\
\hline CHF0 & $5 / 23-5 / 25$ & RM 27 & 446 & 126 & $28.3( \pm 8.8)$ & 244 & $54.8( \pm 17.4)_{\mathrm{A}}$ \\
\hline $\mathrm{CHF0}$ & $5 / 23-5 / 25$ & RM 9 & 596 & 177 & $29.7( \pm 5.9)$ & 340 & $57.1( \pm 11.5)_{\mathrm{A}}$ \\
\hline $\mathrm{STS}^{c}$ & $4 / 10-4 / 12$ & RM $79^{d}$ & 569 & 61 & $10.7( \pm 0.8)$ & 281 & $49.4( \pm 2.2)_{\mathrm{A}}$ \\
\hline $\mathrm{STS}^{c}$ & $4 / 10-4 / 12$ & RM 65 & 569 & 48 & $8.5( \pm 2.3)$ & 241 & $42.4( \pm 18.1)_{\mathrm{A}}$ \\
\hline $\mathrm{STS}^{c}$ & $4 / 10-4 / 12$ & RM 48 & 563 & 68 & $12.1( \pm 2.6)$ & 333 & $59.1( \pm 11.4)_{\mathrm{A}}$ \\
\hline $\mathrm{STS}^{c}$ & $4 / 10-4 / 12$ & RM 27 & 381 & 75 & $20.5( \pm 5.3)$ & 281 & $76.9( \pm 24.0)_{\mathrm{AB}}$ \\
\hline $\mathrm{STS}^{c}$ & $4 / 10-4 / 12$ & RM 9 & 383 & 107 & $28.2( \pm 5.1)$ & 382 & $101.1( \pm 21.8)_{\mathrm{B}}$ \\
\hline
\end{tabular}

a $C H S=$ yearling spring chinook salmon, CHFO = subyearling fall chinook salmon, STS = summer steelhead.

$b$ Abundance represents total abundance. See Methods for abundance estimation method.

$c$ Comprised of large-grade and medium-grade steelhead.

$d$ Rivermile 2 of Meacham Creek at rivermile 79 of Umatilla River. 
Table 18. Percent detection of PIT-tagged fish released for reach-specific survival tests and detected at Columbia River interrogation sites and all sites, March - July 2000. Means with the same letter are not significantly different. Duplicate detections are omitted.

\begin{tabular}{|c|c|c|c|c|c|c|c|}
\hline Species $^{a}$ & $\begin{array}{c}\text { Release } \\
\text { dates }\end{array}$ & $\begin{array}{c}\text { Release } \\
\text { site }\end{array}$ & $\begin{array}{l}\text { Release } \\
\text { number }\end{array}$ & $\begin{array}{c}\text { Mainstem } \\
\text { number } \\
\text { detected }^{b}\end{array}$ & $\begin{array}{c}\text { Mean \% } \\
\text { detection } \\
\text { (95\% C.I.) }\end{array}$ & $\begin{array}{c}\text { Total } \\
\text { detection }^{c}\end{array}$ & $\begin{array}{c}\text { Mean \% } \\
\text { detection } \\
\text { (95\% C.I.) }\end{array}$ \\
\hline $\mathrm{CHS}$ & $3 / 7-3 / 9$ & RM 80 & 1,002 & 183 & $18.3( \pm 2.1)$ & 193 & $19.3( \pm 2.5) \mathrm{A}$ \\
\hline CHS & $3 / 7-3 / 9$ & RM 27 & 1,000 & 241 & $24.1( \pm 3.6)$ & 251 & $25.1( \pm 3.1) \mathrm{AB}$ \\
\hline CHS & $3 / 7-3 / 9$ & RM 9 & 777 & 209 & $26.6( \pm 3.0)$ & 220 & $27.9( \pm 3.1)$ В \\
\hline CHF0 & $5 / 23-5 / 25$ & RM 74 & 447 & 18 & $4.0( \pm 3.2)_{\mathrm{A}}$ & 116 & $25.9( \pm 10.8)$ \\
\hline CHF0 & $5 / 23-5 / 25$ & RM 56 & 448 & 26 & $5.8( \pm 1.3)_{\mathrm{A}}$ & 147 & $32.8( \pm 5.3) \mathrm{A}$ \\
\hline CHF0 & $5 / 23-5 / 25$ & RM 27 & 446 & 34 & $7.6( \pm 2.6)_{\mathrm{A}}$ & 160 & $36.0( \pm 11.3) \mathrm{A}$ \\
\hline CHF0 & $5 / 23-5 / 25$ & RM 9 & 596 & 49 & $8.3( \pm 5.3)_{\mathrm{A}}$ & 226 & $38.0( \pm 6.8) \mathrm{A}$ \\
\hline CHF0 & $5 / 23-5 / 25$ & RM 0 & 1,892 & 297 & $15.7( \pm 0.8)_{\mathrm{B}}$ & & \\
\hline $\mathrm{STS}^{d}$ & $4 / 10-4 / 12$ & $\mathrm{RM} 79^{e}$ & 569 & 27 & $4.7( \pm 1.7)$ & 88 & $15.5( \pm 0.8) \mathrm{A}$ \\
\hline $\mathrm{STS}^{d}$ & $4 / 10-4 / 12$ & RM 65 & 569 & 26 & $4.6( \pm 0.7)$ & 74 & $13.0( \pm 2.7) \mathrm{A}$ \\
\hline $\mathrm{STS}^{d}$ & $4 / 10-4 / 12$ & RM 48 & 563 & 28 & $4.9( \pm 1.6)$ & 96 & $17.0( \pm 2.6) \mathrm{A}$ \\
\hline $\mathrm{STS}^{d}$ & $4 / 10-4 / 12$ & RM 27 & 381 & 42 & $11.2( \pm 3.7)$ & 117 & $31.6( \pm 7.1)$ в \\
\hline $\mathrm{STS}^{d}$ & $4 / 10-4 / 12$ & RM 9 & 383 & 30 & $7.9( \pm 0.8)$ & 137 & $36.1( \pm 5.2)$ в \\
\hline
\end{tabular}

a $C H S=$ yearling spring chinook salmon, CHFO = subyearling fall chinook salmon, STS = summer steelhead (large-grade).

$b$ Interrogation sites in the mainstem Columbia River included John Day and Bonneville dams and the Columbia River estuary. Tags were also recovered within island bird colonies.

$c$ Total detection included Umatilla River and mainstem detections and island recoveries.

${ }^{d}$ Comprised of large-grade and medium-grade steelhead.

e Rivemile 2 of Meacham Creek at rivermile 79 of the Umatilla River. 
Table 19. Correlations of daily detections with mean river flow $\left(\mathrm{ft}^{3} / \mathrm{s}\right)$ at $\mathrm{RM} 37.6$, temperature $\left({ }^{\circ} \mathrm{F}\right)$ at $\mathrm{RM} 37.6$, and Secchi depth (m) at RM 3.7, lower Umatilla River, March - June 2000. * indicates significance $(P<0.05)$.

\begin{tabular}{|c|c|c|c|c|c|c|c|c|c|}
\hline \multirow[b]{2}{*}{ Species $^{a}$} & \multicolumn{3}{|c|}{ Flow } & \multicolumn{3}{|c|}{ Temperature } & \multicolumn{3}{|c|}{ Secchi } \\
\hline & $\mathrm{r}$ & $P$ & $\mathrm{~N}$ & $\mathrm{r}$ & $P$ & $\mathrm{~N}$ & $\mathrm{r}$ & $P$ & $\mathrm{~N}$ \\
\hline HCHS & -0.281 & $0.018^{*}$ & 70 & 0.344 & $0.004 *$ & 67 & 0.374 & $0.001^{*}$ & 70 \\
\hline $\mathrm{HCHF}$ & -0.517 & $<0.001 *$ & 55 & 0.571 & $<0.001 *$ & 55 & 0.692 & $<0.001 *$ & 55 \\
\hline HCHF0 & -0.112 & 0.637 & 20 & 0.018 & 0.941 & 20 & 0.191 & 0.418 & 20 \\
\hline HSTS (large) & -0.108 & 0.359 & 74 & 0.141 & 0.231 & 74 & 0.042 & 0.720 & 74 \\
\hline HSTS (small) & 0.293 & $0.054^{*}$ & 44 & -0.109 & 0.480 & 44 & -0.119 & 0.443 & 44 \\
\hline $\mathrm{NCOH}$ & 0.022 & 0.882 & 46 & 0.311 & $0.035^{*}$ & 46 & -0.228 & 0.128 & 46 \\
\hline NSTS & -0.316 & $0.011^{*}$ & 64 & 0.235 & 0.061 & 64 & 0.283 & $0.023 *$ & 64 \\
\hline
\end{tabular}

a HCHS = hatchery spring chinook salmon, HCHF = hatchery fall chinook salmon, HCHF0 = hatchery subyearling fall chinook salmon, HSTS (large) = large-grade hatchery summer steelhead, HSTS (small) = small-grade hatchery summer steelhead, NCOH = natural coho salmon, and NSTS = natural summer steelhead. 
Table 20. Percent detection of natural coho salmon and summer steelhead within discrete environmental parameters. Percent values in parentheses correspond to the proportion of time the parameter was represented within each species' detection period, Umatilla River, 2000. * indicates significance $(P<0.05)$.

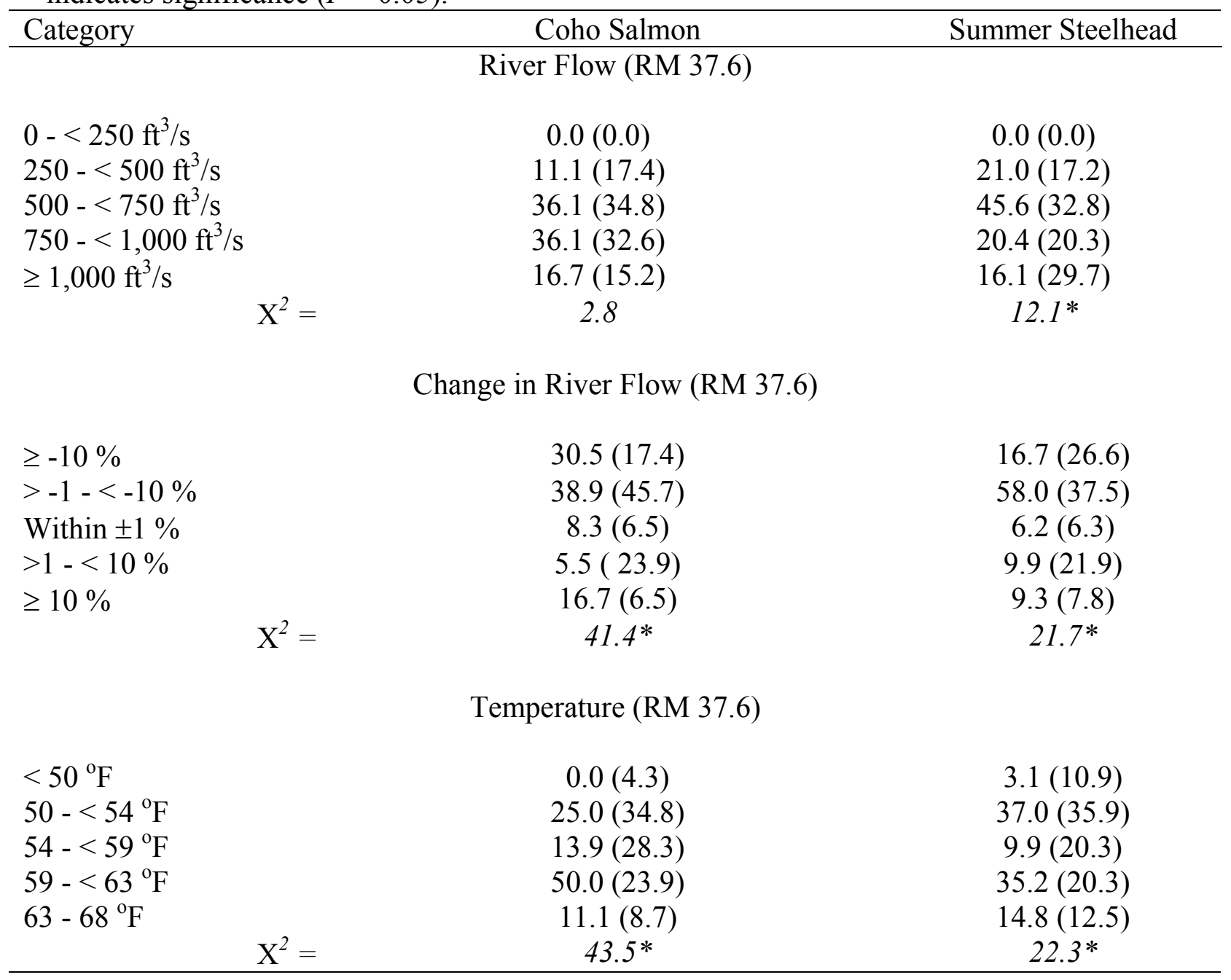


Table 21. Correlations between travel speed $(\mathrm{mi} / \mathrm{d})$ and mean river flow $\left(\mathrm{ft}^{3} / \mathrm{s}\right)$ within the travel corridor and travel speed (mi/d) and delta flow $\left(\mathrm{ft}^{3} / \mathrm{s}\right)$ within the travel corridor based on daily detections of hatchery fish released for reach-specific survival tests, Umatilla River, 2000. The $\mathrm{r}$-value is presented with the $\mathrm{N}$-value in parentheses. * indicates significance $(P<0.05)$.

\begin{tabular}{lccc} 
& \multicolumn{3}{c}{ Species $^{a}$} \\
\cline { 2 - 4 } Release site and RM & CHS & CHF0 & STS (large) \\
\hline & \multicolumn{2}{c}{ Travel Speed and Mean River Flow } \\
Imeques (RM 80) & $-0.720(10)^{*}$ & \\
Bonifer (RM 79) & & & $0.841(61)^{*}$ \\
Thornhollow (RM 74) & & $-0.863(98)^{*}$ & $0.842(48)^{*}$ \\
Minthorn (RM 65) & & $-0.881(121)^{*}$ & \\
ODFW (RM 56) & & & $0.720(68)^{*}$ \\
Rieth (RM 48) & $-0.369(10)$ & $0.122(126)$ & $0.654(75)^{*}$ \\
Echo (RM 27) & $0.427(11)$ & $-0.043(177)$ & $0.677(107)^{*}$ \\
Steelhead Park (RM 9) & & \\
& & & \\
& & & \\
Imeques (RM 80) & $-0.033(10)$ & $-0.821(98)^{*}$ & $0.801(61)^{*}$ \\
Bonifer (RM 79) & & & $0.802(48)^{*}$ \\
Thornhollow (RM 74) & & $-0.845(121)^{*}$ & \\
Minthorn (RM 65) & & & $0.663(68)^{*}$ \\
ODFW (RM 56) & & $0.383(126)^{*}$ & $0.543(75)^{*}$ \\
Rieth (RM 48) & & $-0.087(177)$ & $0.585(107)^{*}$ \\
Echo (RM 27) & $0.205(10)$ & \\
Steelhead Park (RM 9) & $0.332(11)$ & & \\
\hline
\end{tabular}

${ }^{a}$ CHS = spring chinook salmon, CHFO = subyearling fall chinook salmon, and STS (large) =large-grade summer steelhead.

${ }^{b}$ Delta flow is the difference between the maximum and minimum daily flows $\left(f t^{3} / s\right)$. 
Table 22. Correlations by species between diversion rate and trap efficiency estimates at West Extension Canal (RM 3.7), Umatilla River, March - July 2000. * indicates significance $(P<$ $0.05)$.

\begin{tabular}{lccc} 
Species $^{a}$ & $\mathrm{r}$ & $P$ & $\mathrm{~N}^{b}$ \\
\hline HCHS & 0.606 & 0.149 & 7 \\
HCHF & 0.735 & $0.038^{*}$ & 8 \\
HCHF0 & 0.495 & 0.259 & 7 \\
HSTS & 0.143 & 0.713 & 9 \\
NCH0 & 1.000 & $0.008^{*}$ & 3 \\
NSTS & -- & -- & 2 \\
\hline
\end{tabular}

a HCHS = hatchery spring chinook salmon, HCHF = hatchery yearling fall chinook salmon, HCHFO = hatchery subyearling fall chinook salmon, HSTS = hatchery summer steelhead, $\mathrm{NCHO}=$ natural subyearling chinook salmon, and NSTS = natural summer steelhead .

$b \quad N$ is the number of trap efficiency releases for each species. 
Table 23. Number and length range $(\mathrm{mm})$ of resident fish species captured at the rotary-screw trap (RM 1.2) and West Extension Canal (RM 3.7), lower Umatilla River, October 1999 October 3, 2000.

Family, $\quad$ Number captured $^{a} \quad$ Length range

Common name (genus species)

RST WEID $(\mathrm{mm})^{b}$

\section{Catostomidae}

Unidentified sucker (Castostomus spp.)

$118 \quad 1435$

\section{Centrarchidae}

Bluegill (lepomis macrochirus)

Pumkinseed (lepomis gibbosus)

Unidentified bass (Micropterus spp.)

Unidentified crappie (Promoxis spp.)

$\begin{array}{ccc}- & 8 & - \\ - & 26 & - \\ 29 & 182 & 42-228 \\ 1 & 39 & -\end{array}$

\section{Cottidae}

Unidentified sculpin (cottus spp)

\section{Cyprinidae}

Chiselmouth (Acrocheilus alutaceus)

Common carp (Cyprinus carpio)

Northern pikeminnow (Ptychoceilus oregonensis)

Redside shiner (Richarsonios balteatus)

Unidentified dace (Rhinichthys spp.)

4

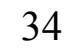

$3 \quad 52$

$8 \quad 652$

Ictaluridae

Unidentified bullhead (Ictalurus spp.)

Percidae

Yellow perch (Perca flavescens)

\section{Poeciliidae}

Mosquitofish (Gambusia affinis)
92

134

$2 \quad 10$

233

10

$10-$

$-1$

$-1$

a Only northern pikeminnow and bass were counted on a regular basis.

${ }^{b}$ Northern pikeminnow and bass were measured to fork length. 
Table 24. Avian predators observed during sampling at the rotary-screw trap (RM 1.2) and West Extension Canal (RM 3.7), Umatilla River, October 1999 - September 2000.

\begin{tabular}{|c|c|c|c|c|}
\hline Month $^{a}$ & Species & $\begin{array}{c}\text { Actual } \\
\text { number } \\
\text { observed }\end{array}$ & $\begin{array}{c}\text { Standardized } \\
\text { number } \\
\text { observed }^{b}\end{array}$ & Location \\
\hline \multirow[t]{2}{*}{ October } & Seagull & 1 & 0.07 & flying \\
\hline & Kingfisher & 4 & 0.27 & flying (3), trapline (1) \\
\hline \multirow[t]{2}{*}{ January } & Great Blue Heron & 1 & 0.08 & flying \\
\hline & Merganser & 5 & 0.38 & river \\
\hline \multirow[t]{7}{*}{ March } & Seagull & 75 & 0.93 & dam (13), flying (40), forebay (22) \\
\hline & Cormorant & 77 & 1.11 & $\operatorname{dam}(3)$, flying (17), forebay (57) \\
\hline & Great Blue Heron & 23 & 0.26 & flying (6), forebay (12), river (5) \\
\hline & Coot & 11 & 0.12 & forebay \\
\hline & Kingfisher & 8 & 0.09 & forebay (5), outfall (2), river (1) \\
\hline & Merganser & 12 & 0.12 & forebay (9), river (3) \\
\hline & Night Heron & 18 & 0.16 & forebay (2), river (16) \\
\hline \multirow[t]{7}{*}{ April } & Seagull & 172 & 1.92 & $\begin{array}{l}\text { dam (6), flying (117), forebay (23), } \\
\text { river (15), none (11) }\end{array}$ \\
\hline & Cormorant & 128 & 1.48 & flying (42), forebay (72), none (14) \\
\hline & Great Blue Heron & 34 & 0.39 & $\begin{array}{l}\text { canal (11), flying (2), forebay (6), } \\
\text { river (13), none ( } 2)\end{array}$ \\
\hline & Kingfisher & 23 & 0.26 & $\begin{array}{l}\text { canal (1), dam (2), forebay (16), } \\
\text { river (4) }\end{array}$ \\
\hline & Merganser & 1 & 0.01 & forebay \\
\hline & Night Heron & 3 & 0.03 & outfall \\
\hline & Osprey & 7 & 0.08 & forebay (1), river (5), none (1) \\
\hline \multirow[t]{7}{*}{ May } & Seagull & 1,454 & 15.05 & $\begin{array}{l}\text { canal (11), dam (331), flying (59), } \\
\text { forebay (824), river (229) }\end{array}$ \\
\hline & Cormorant & 211 & 2.31 & dam (28), forebay (183) \\
\hline & Great Blue Heron & 83 & 0.93 & $\begin{array}{l}\text { dam (2), flying (3), forebay (14), } \\
\text { river (64) }\end{array}$ \\
\hline & Kingfisher & 4 & 0.04 & canal (2), forebay (1), river (1) \\
\hline & Merganser & 2 & 0.02 & forebay \\
\hline & Night Heron & 49 & 0.57 & flying (1), outfall (32), river (16) \\
\hline & Osprey & 14 & 0.16 & flying (1), forebay (3), river (10) \\
\hline
\end{tabular}

a October through February observations were made at the rotary-screw trap (RM 1.2); March through September observations were made at West Extension Canal (RM 3.7).

$b$ Monthly standardized observations are the mean of total avian predators observed per day divided by the total number of observations per day. 
Table 24. Continued.

\begin{tabular}{|c|c|c|c|c|}
\hline Month $^{a}$ & Species & $\begin{array}{c}\text { Actual } \\
\text { number } \\
\text { observed }\end{array}$ & $\begin{array}{c}\text { Standardized } \\
\text { number } \\
\text { observed }^{b}\end{array}$ & Location \\
\hline \multirow[t]{5}{*}{ June } & Seagull & 151 & 1.73 & $\begin{array}{c}\text { dam (28), flying (32), forebay (87), } \\
\text { river (4) }\end{array}$ \\
\hline & Cormorant & 50 & 0.52 & dam $(6)$, forebay $(44)$ \\
\hline & Great Blue Heron & 55 & 0.66 & $\begin{array}{l}\operatorname{dam}(3), \text { flying }(2), \text { forebay }(7), \\
\text { river }(43)\end{array}$ \\
\hline & Night Heron & 41 & 0.53 & $\begin{array}{l}\text { canal (1), dam (1), flying (5), } \\
\text { forebay (2), outfall (19), river (13) }\end{array}$ \\
\hline & Osprey & 9 & 0.11 & flying \\
\hline \multirow[t]{5}{*}{ July } & Seagull & 3 & 0.15 & flying (1), forebay (2) \\
\hline & Cormorant & 1 & 0.05 & forebay \\
\hline & Great Blue Heron & 3 & 0.15 & dam (1), forebay (1), river (1) \\
\hline & Kingfisher & 1 & 0.05 & river \\
\hline & Osprey & 1 & 0.05 & forebay \\
\hline \multirow[t]{2}{*}{ August } & Great Blue Heron & 1 & 0.11 & flying \\
\hline & Night Heron & 1 & 0.11 & dam \\
\hline \multirow[t]{3}{*}{ September } & Seagull & 1 & 0.08 & flying \\
\hline & Great Blue Heron & 1 & 0.08 & river \\
\hline & Osprey & 2 & 0.15 & flying \\
\hline
\end{tabular}




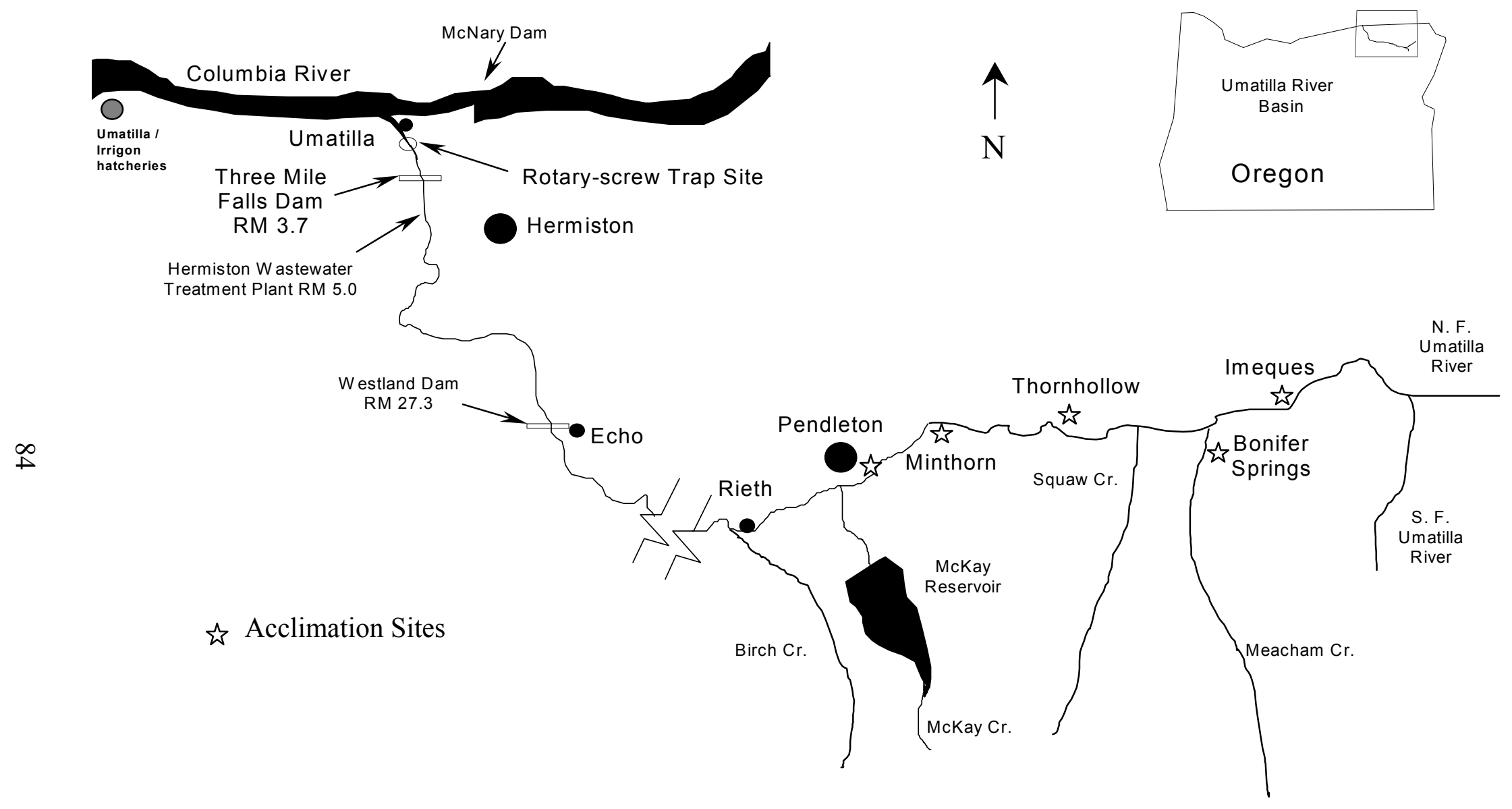

Figure 1. Study and activity sites on the Umatilla River, October 1999 - September 2000. 


\section{ROTARY-SCREW TRAP \\ SITE}
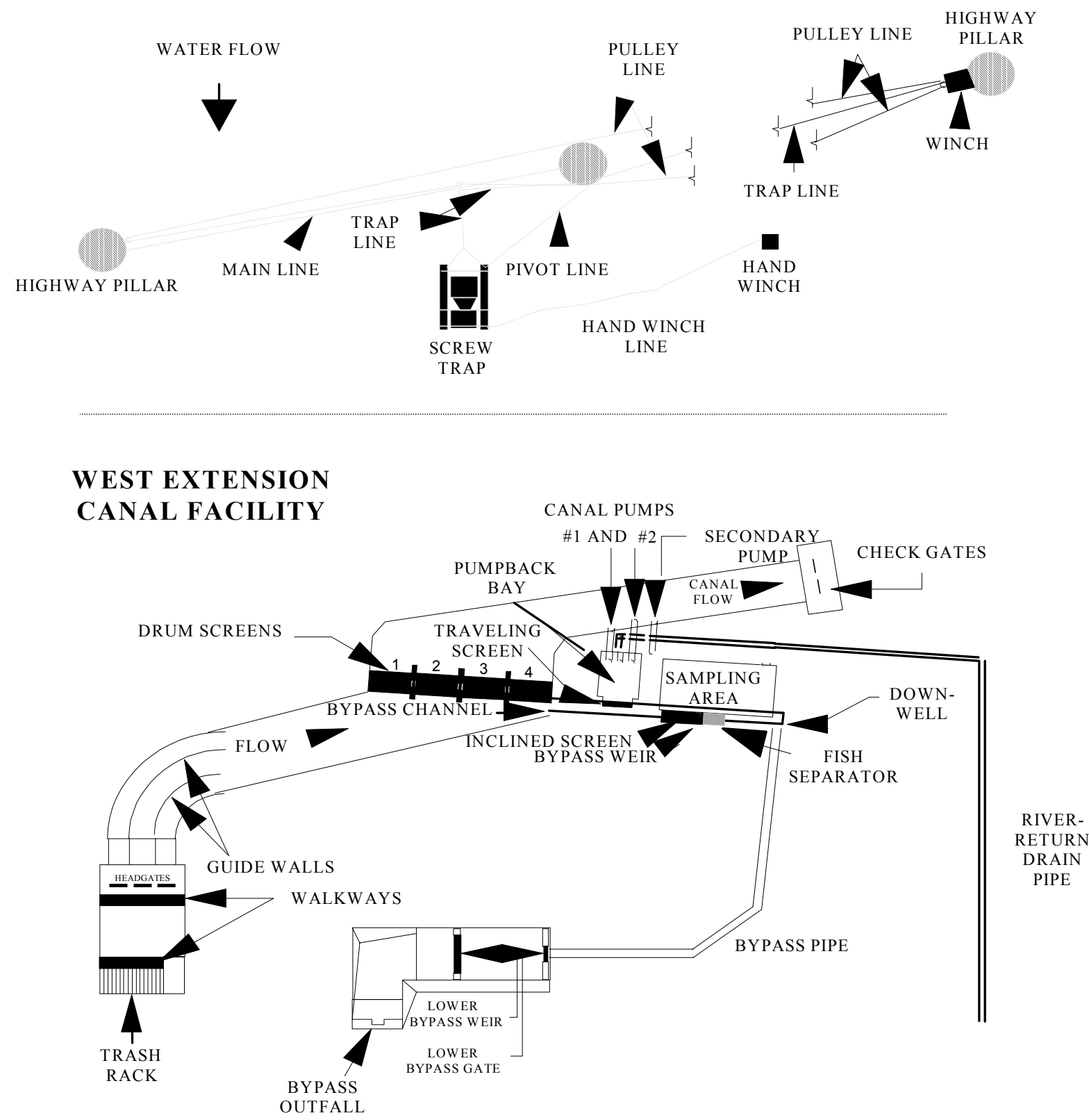

Figure 2. Schematic of the rotary-screw trap with anchoring system and the West Extension Canal screening/bypass facility, lower Umatilla River, 2000. 


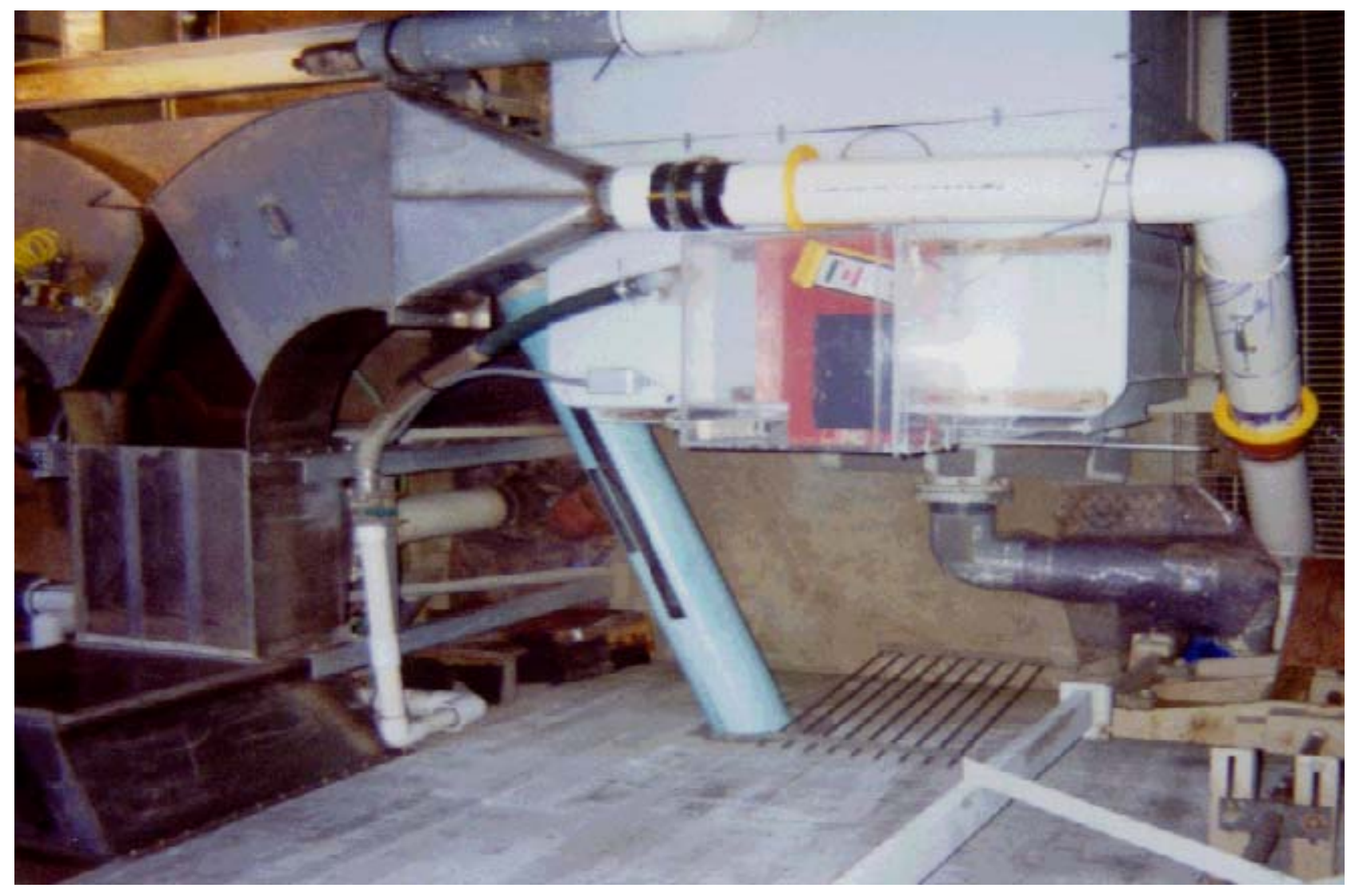

Figure 3. Remote PIT-tag interrogation system $(134 \mathrm{kHz})$ used at West Extension Canal (RM 3.7) in 2000. 

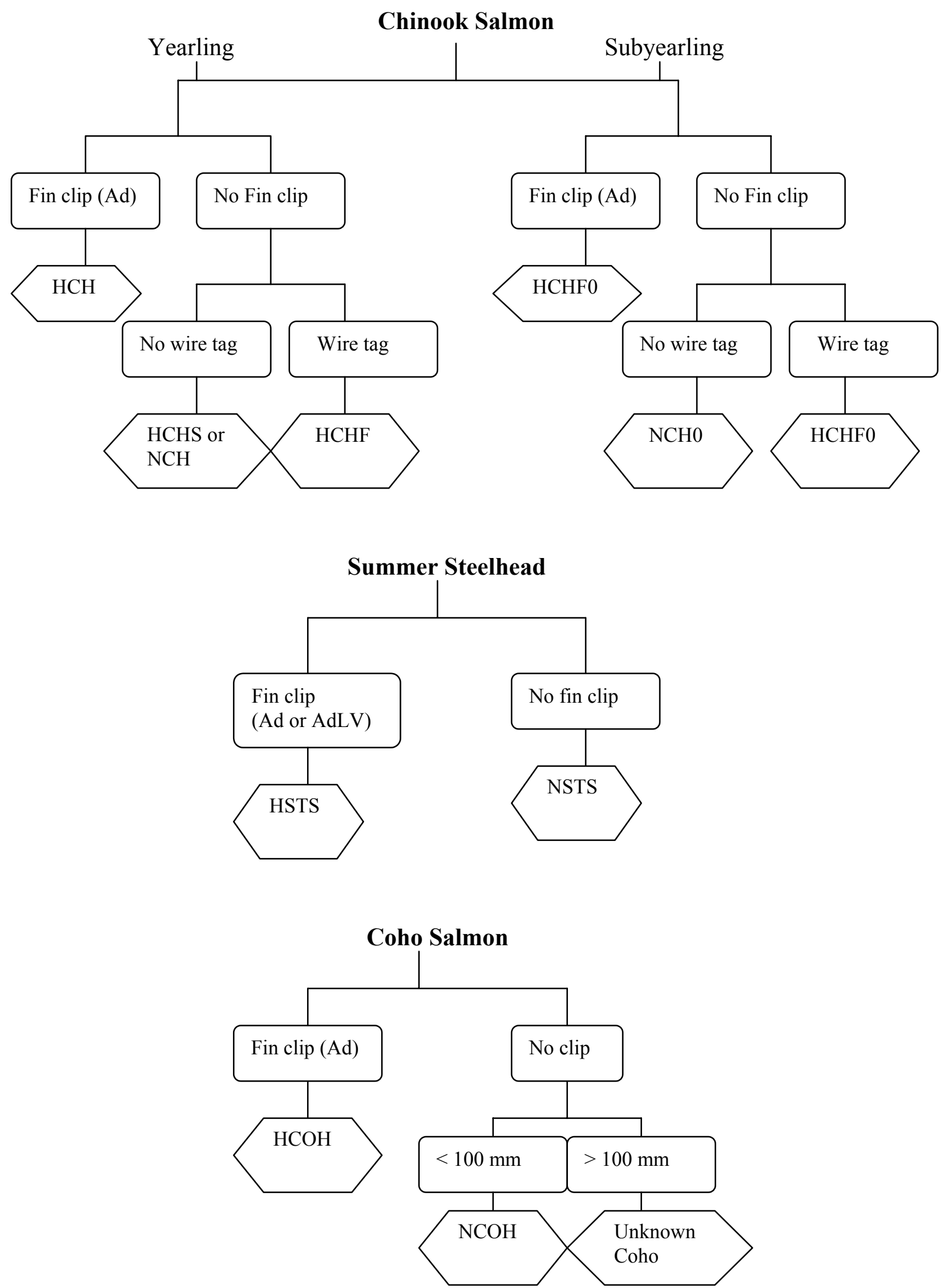

Figure 4. Process used to differentiate species, race, and origin of juvenile migrant fish in the Umatilla River, 2000. 


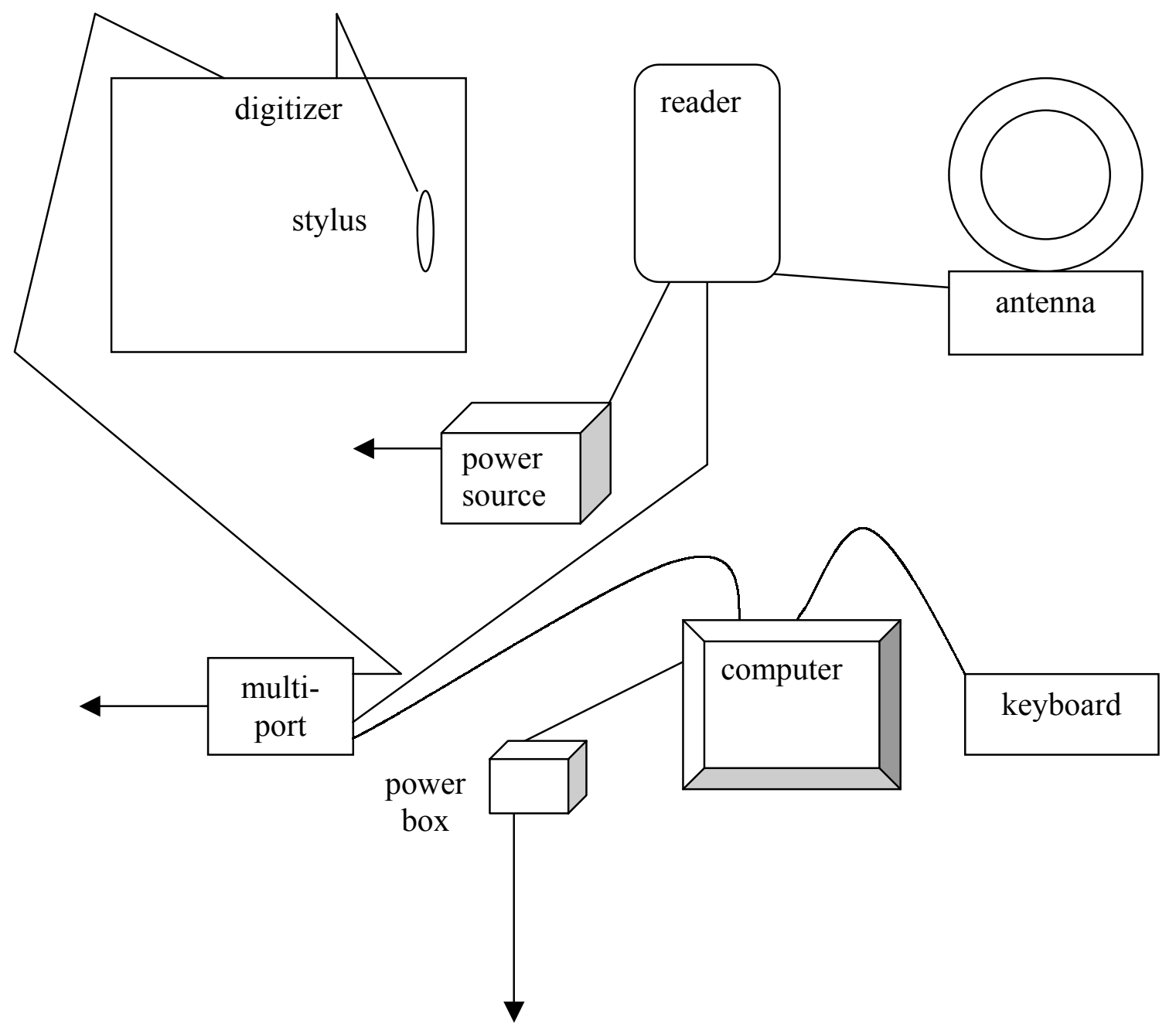

Figure 5. Digitizer board setup used to record biological data in the field, 2000. 


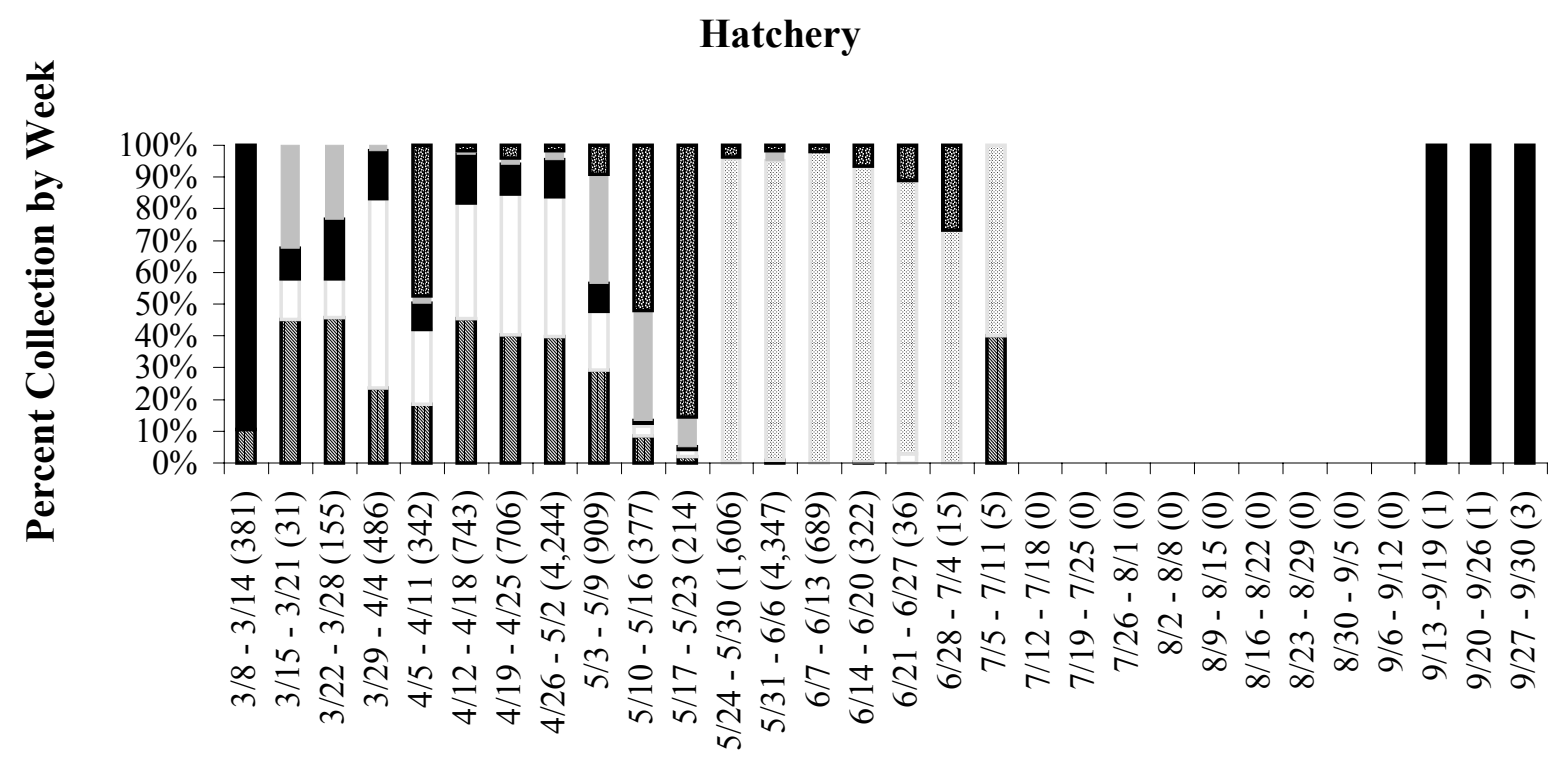

\section{Dates (Weekly Total)}

Spring Chinook

—Unknown Chinook
Fall Chinook

Coho
Subyearling Fall Chinoo

圈 Summer Steelhead

\section{Natural/Unknown}

نै
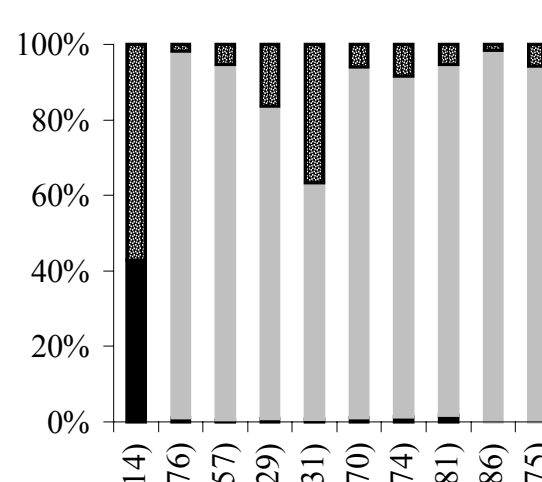

圈 圈
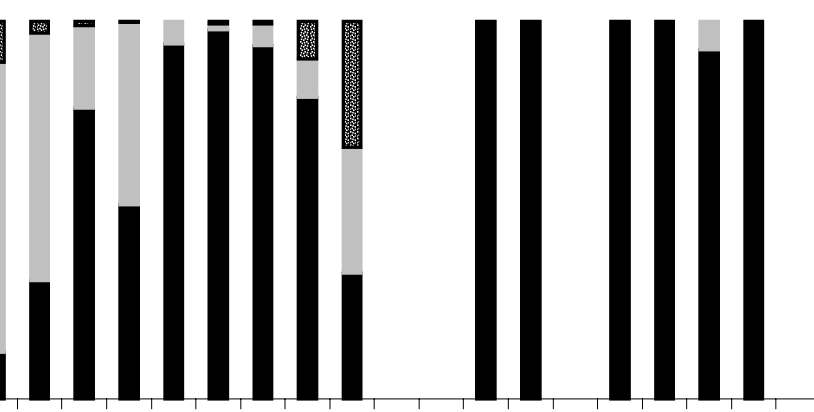

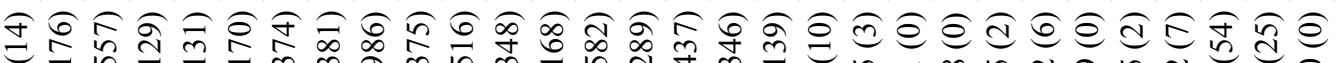

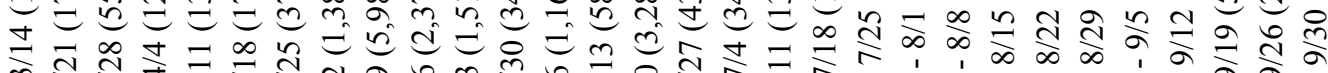

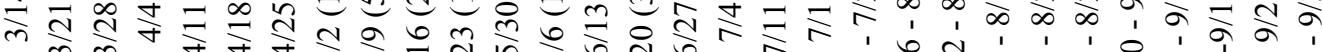

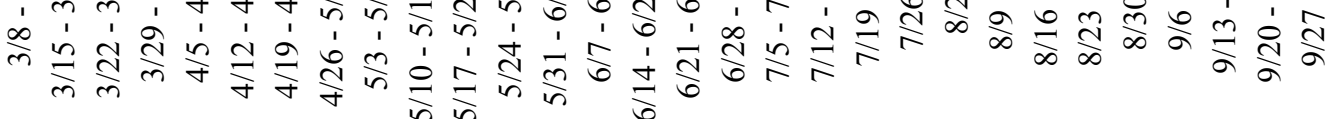

\section{Dates (Weekly Total)}

Chinook

Unknown Coho

國 Summer Steelhead

Figure 6. Weekly composition of hatchery, natural, and unknown juvenile salmonids sampled at West Extension Canal (RM 3.7), lower Umatilla River, March - September 2000. 


\section{Spring Chinook Salmon}

March Releases

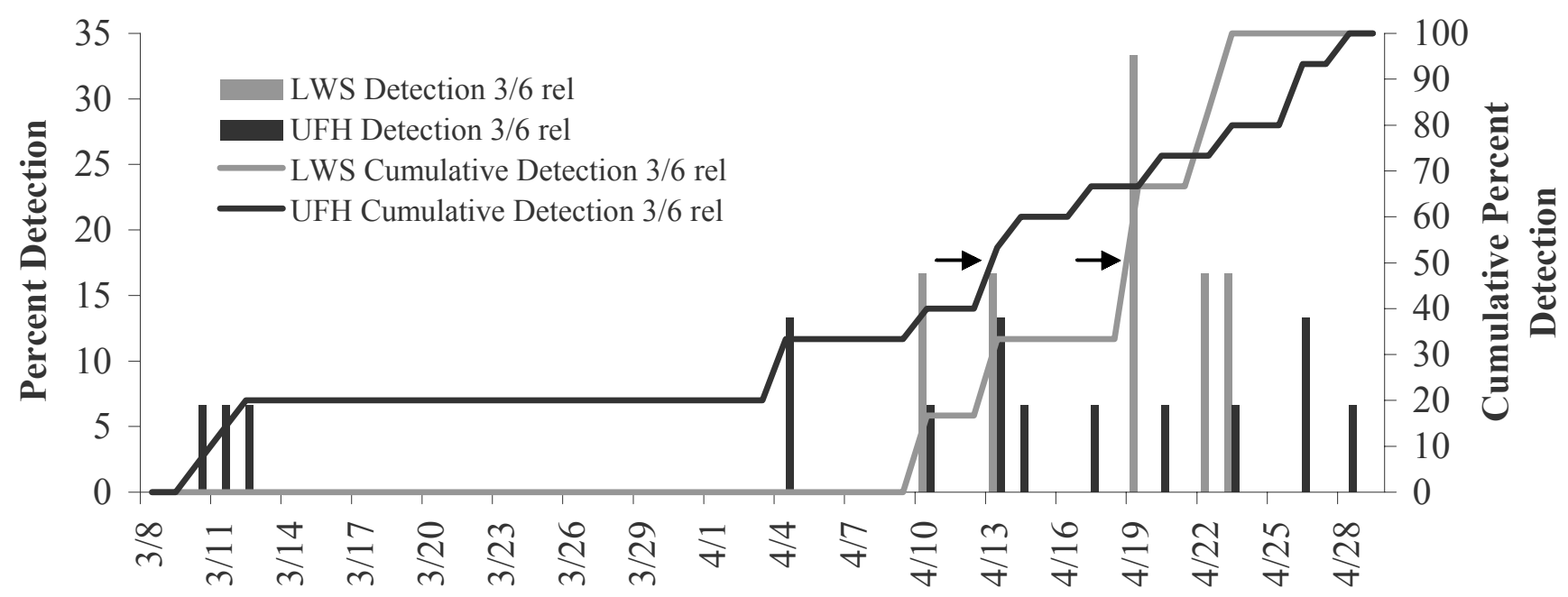

Date

\section{April Releases}

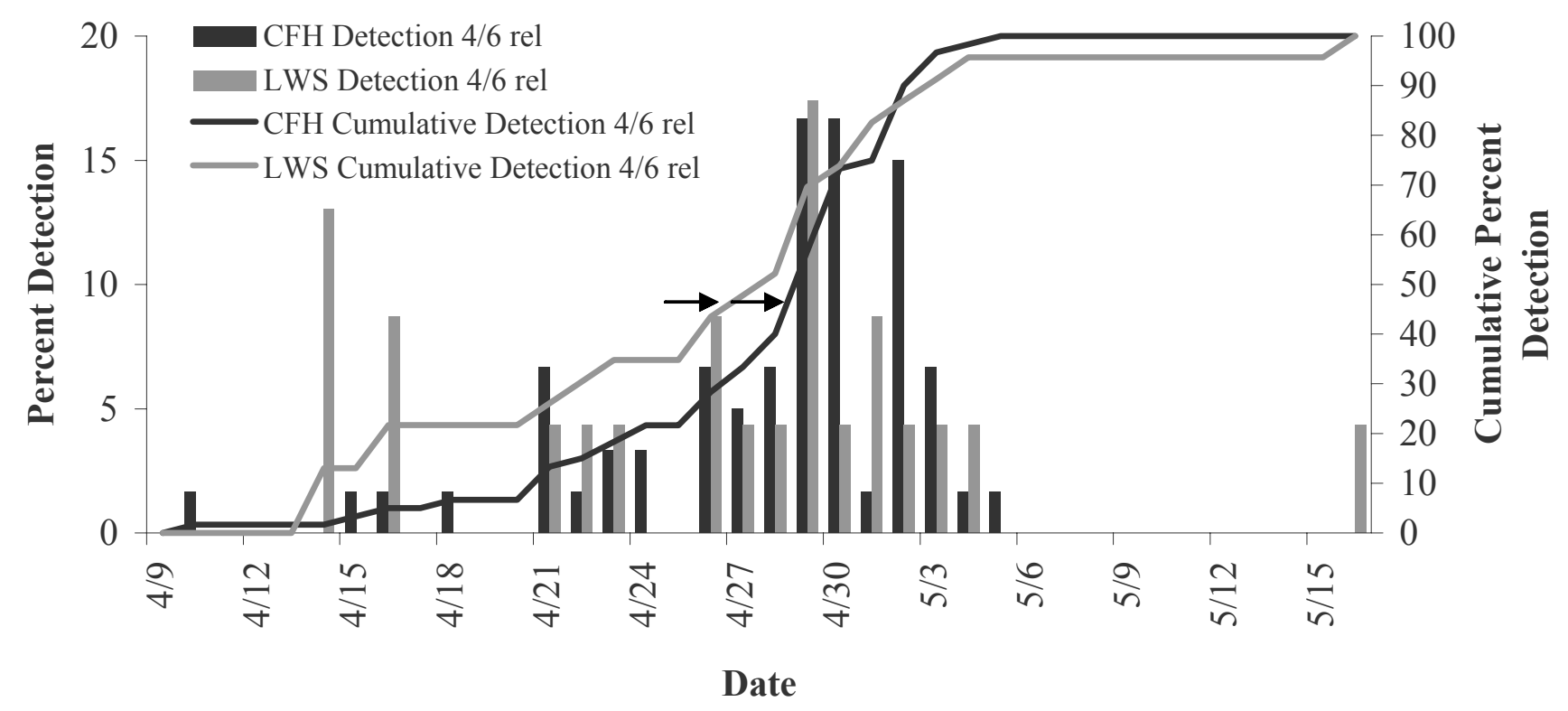

Figure 7. Percent and cumulative percent detection at West Extension Canal (RM 3.7) of March and April releases of PIT-tagged hatchery yearling spring chinook salmon, Umatilla River, March - May 2000. The fiftieth percentile is marked with arrows and volitional release dates are indicated. LWS $=$ Little White Salmon Hatchery, UFH = Umatilla Fish Hatchery, CFH = Carson Fish Hatchery. 


\section{Fall Chinook Salmon}

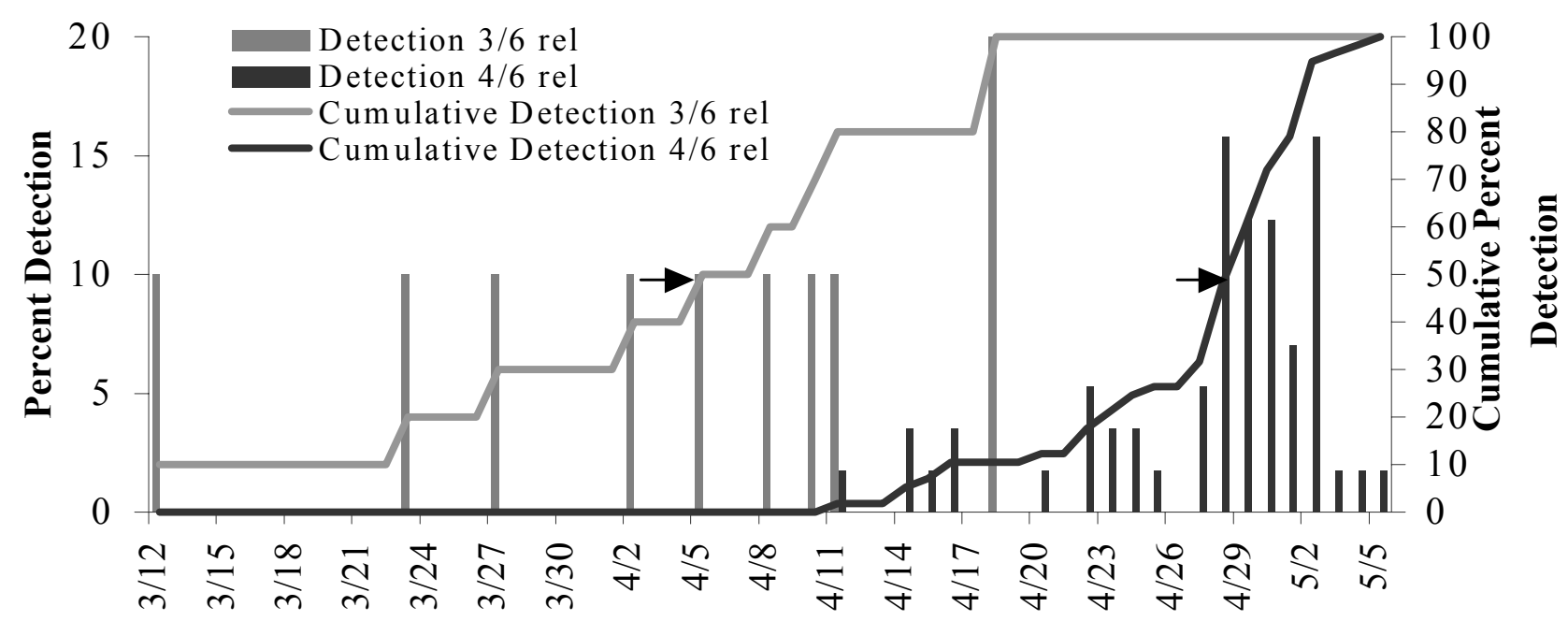

Date

\section{Subyearling Fall Chinook Salmon}

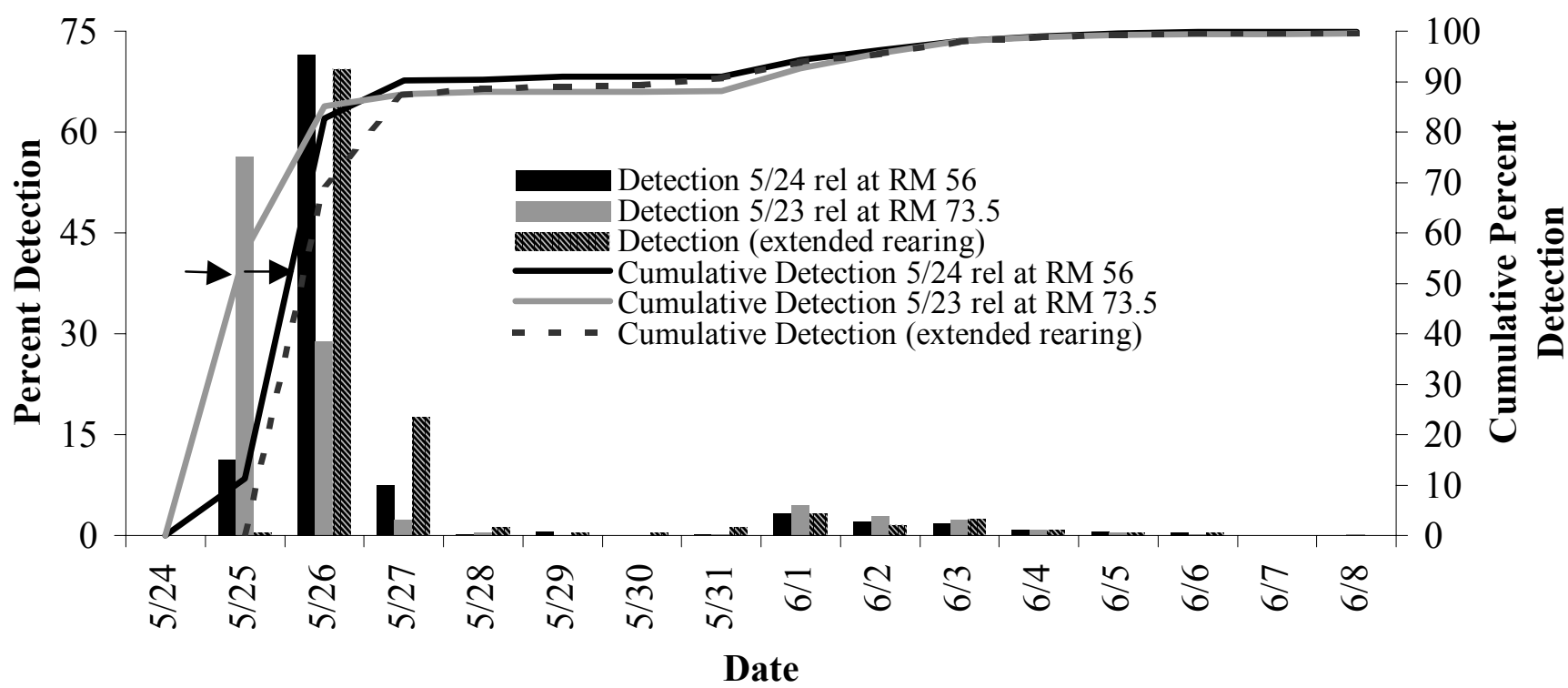

Figure 8. Percent and cumulative percent detection of PIT-tagged hatchery yearling and subyearling fall chinook salmon at West Extension Canal (RM 3.7), Umatilla River, March June 2000. Fiftieth percentile marked with arrows. Release dates are volitional for yearling fall chinook and forced for subyearling fall chinook salmon. 


\section{Summer Steelhead \\ Production Releases}
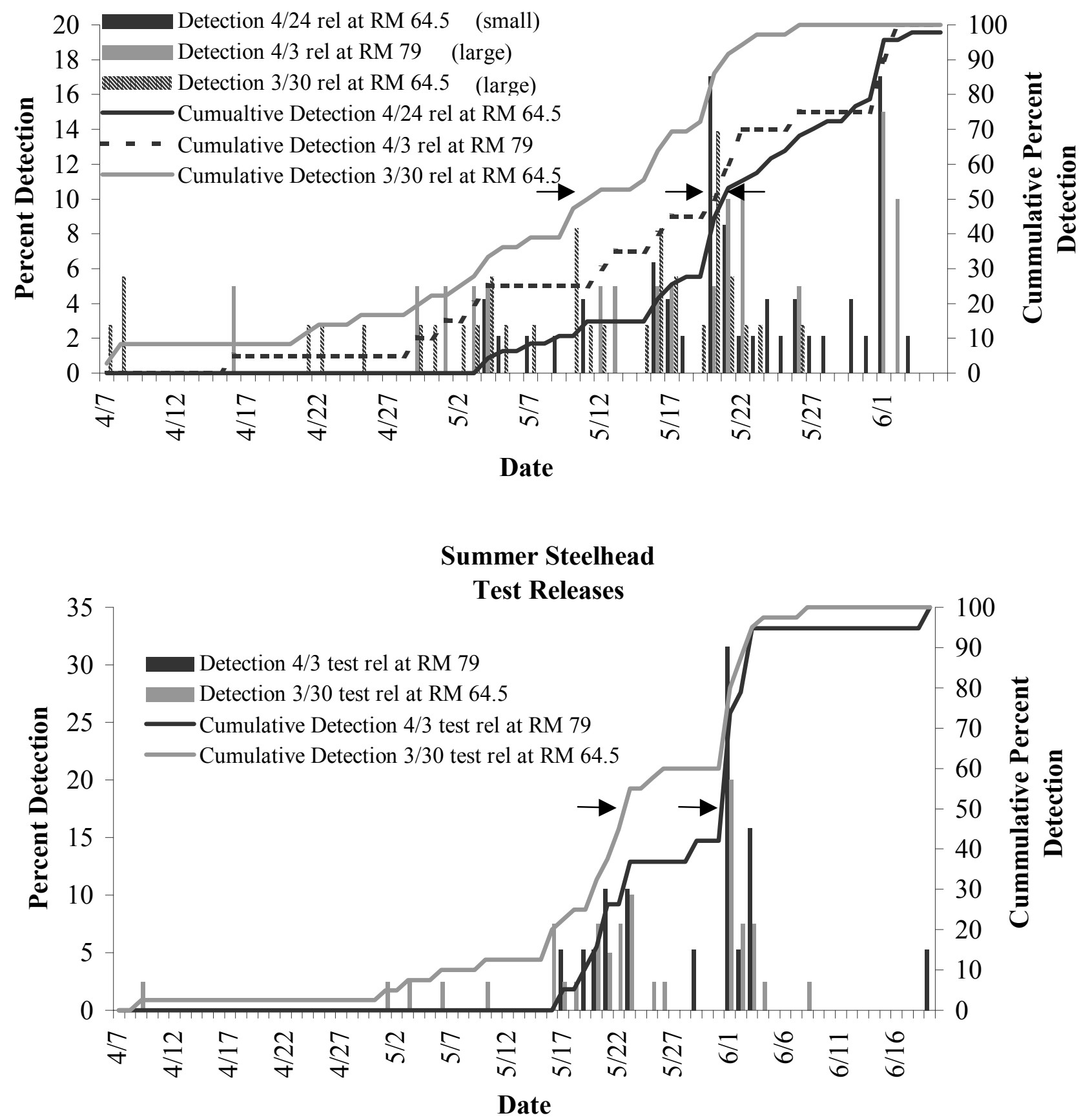

Figure 9. Percent and cumulative percent detection of PIT-tagged hatchery summer steelhead at West Extension Canal (RM 3.7), Umatilla River, April - June 2000. Fiftieth percentile marked with arrows and volitional release dates are indicated. 


\section{Natural Coho Salmon}

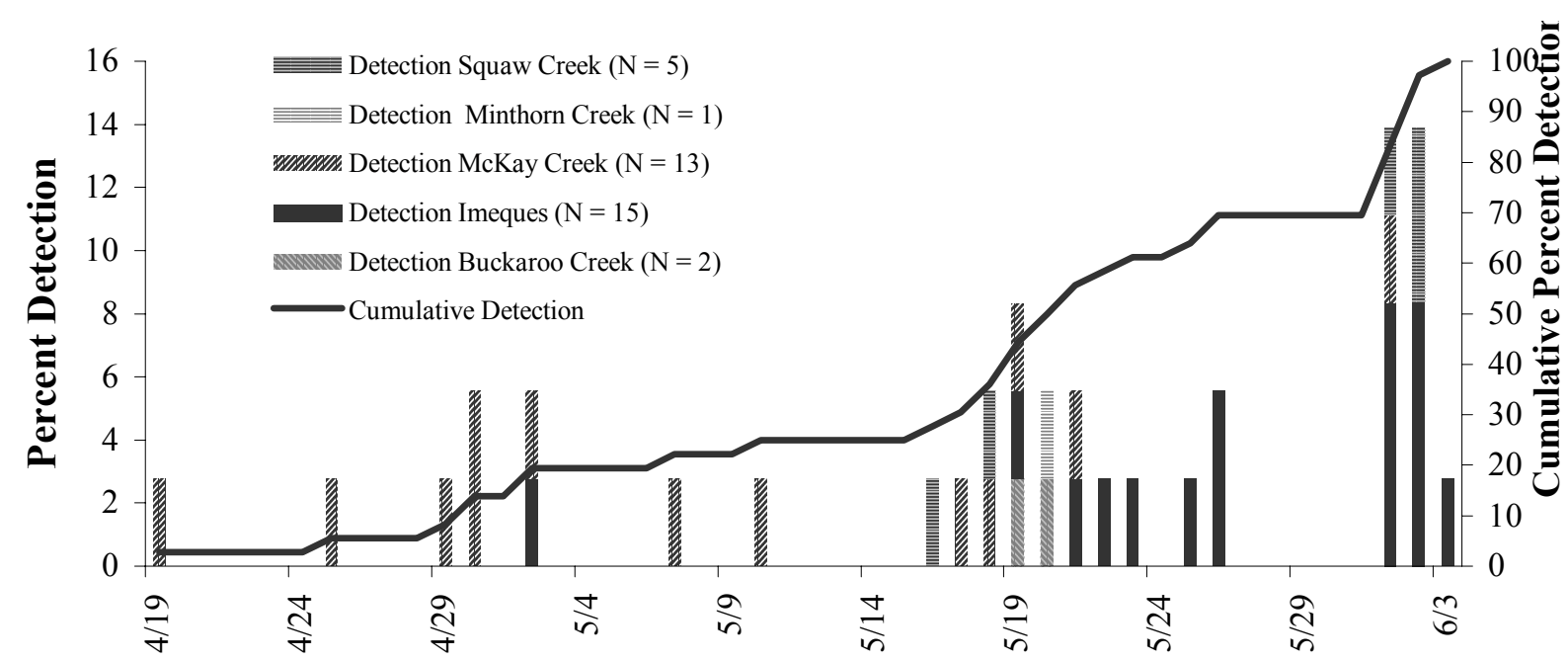

Date

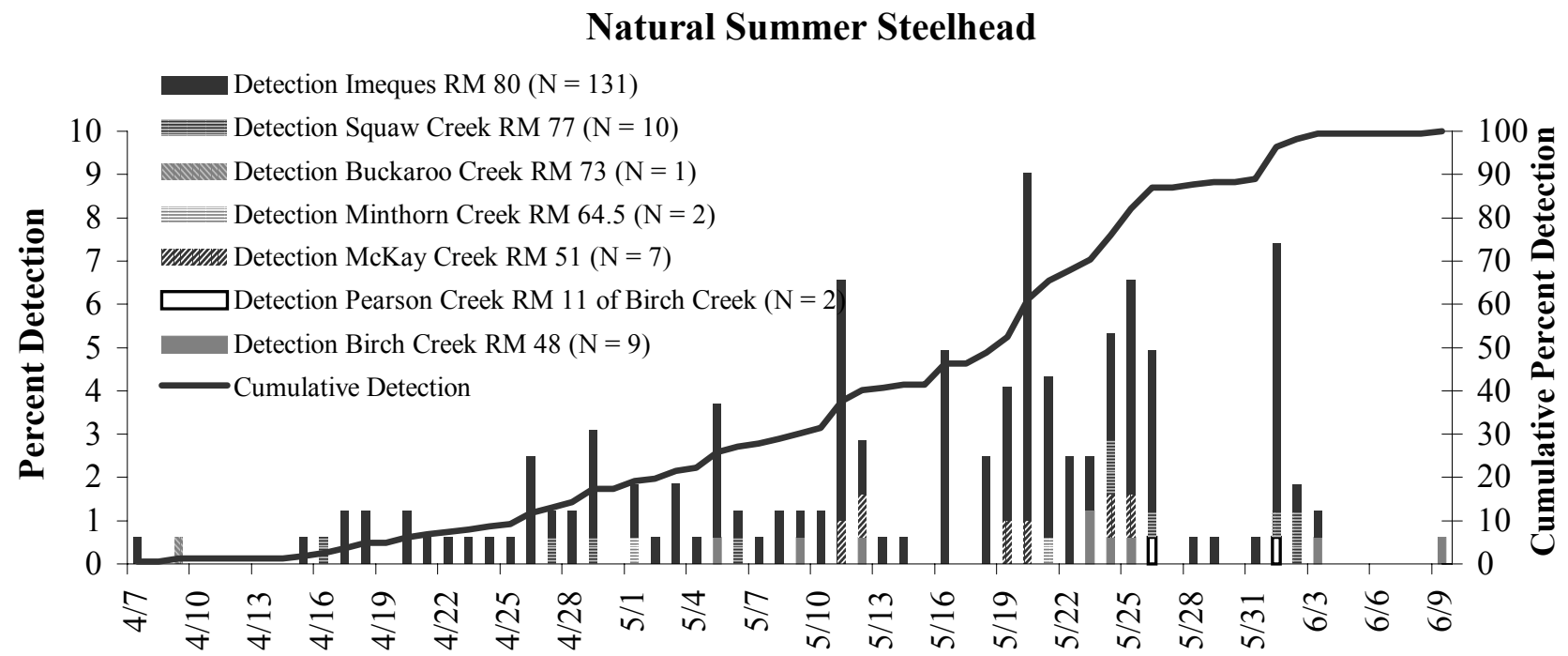

Date

Figure 10. Percent and cumulative percent detection of PIT-tagged natural coho salmon and summer steelhead at West Extension Canal (RM 3.7), Umatilla River, April - June 2000. Sites indicated are where fish were released after being tagged. 


\section{Spring Chinook Salmon}

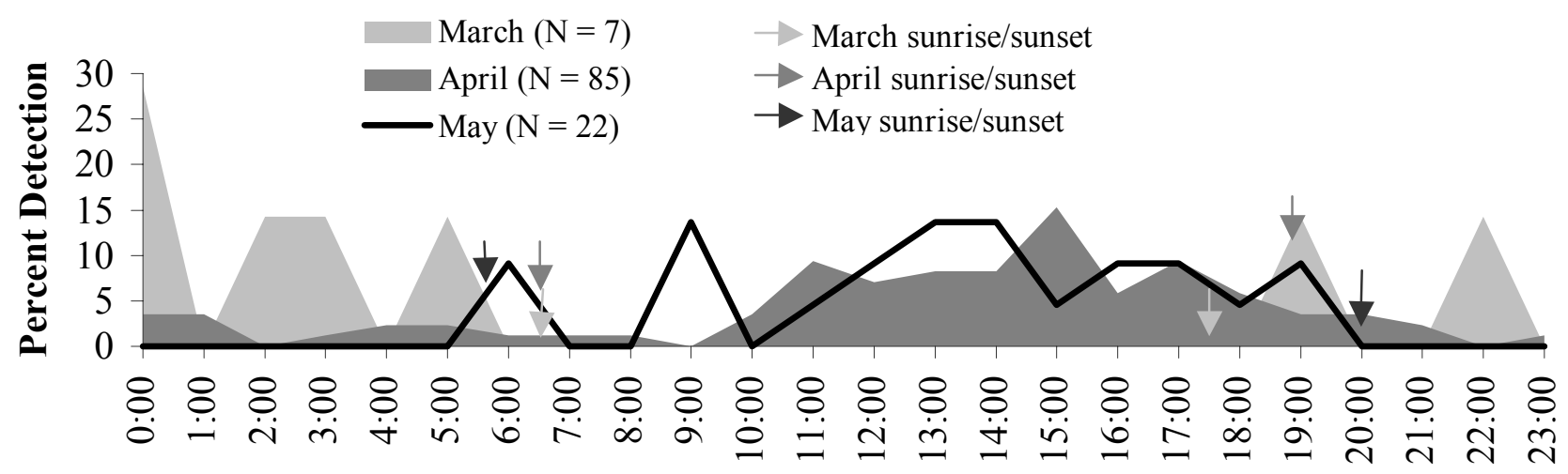

Hour

\section{Fall Chinook Salmon}

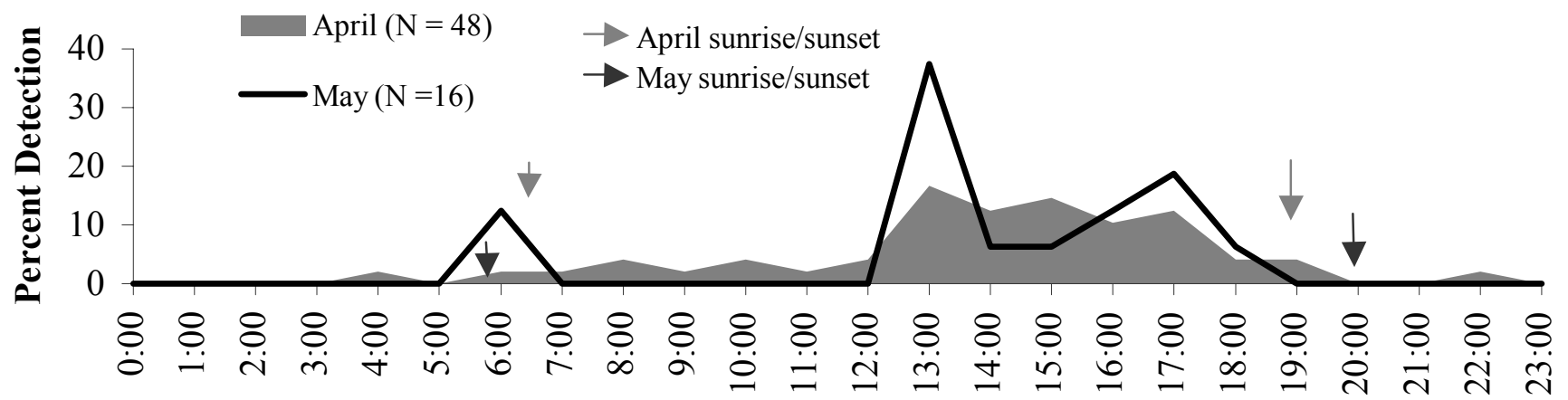

Hour

\section{Subyearling Fall Chinook Salmon}

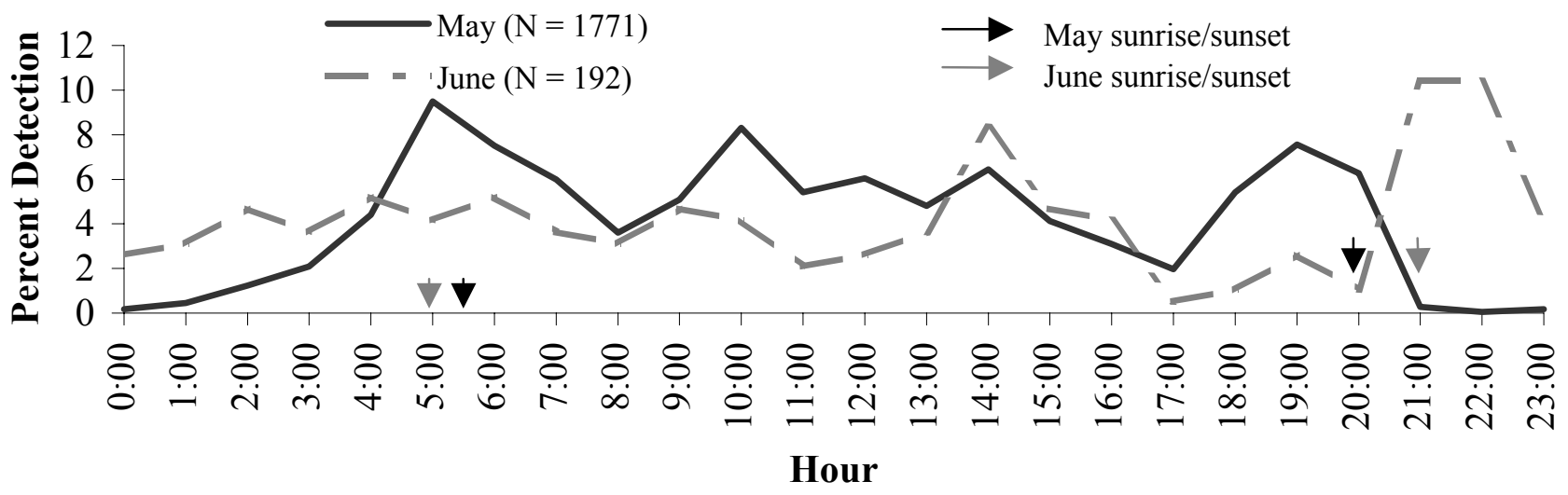

Figure 11. Diel detection of PIT-tagged hatchery yearling spring and fall chinook salmon and subyearling fall chinook salmon at West Extension Canal (RM 3.7), Umatilla River, March June 2000. 


\section{Hatchery Summer Steelhead}

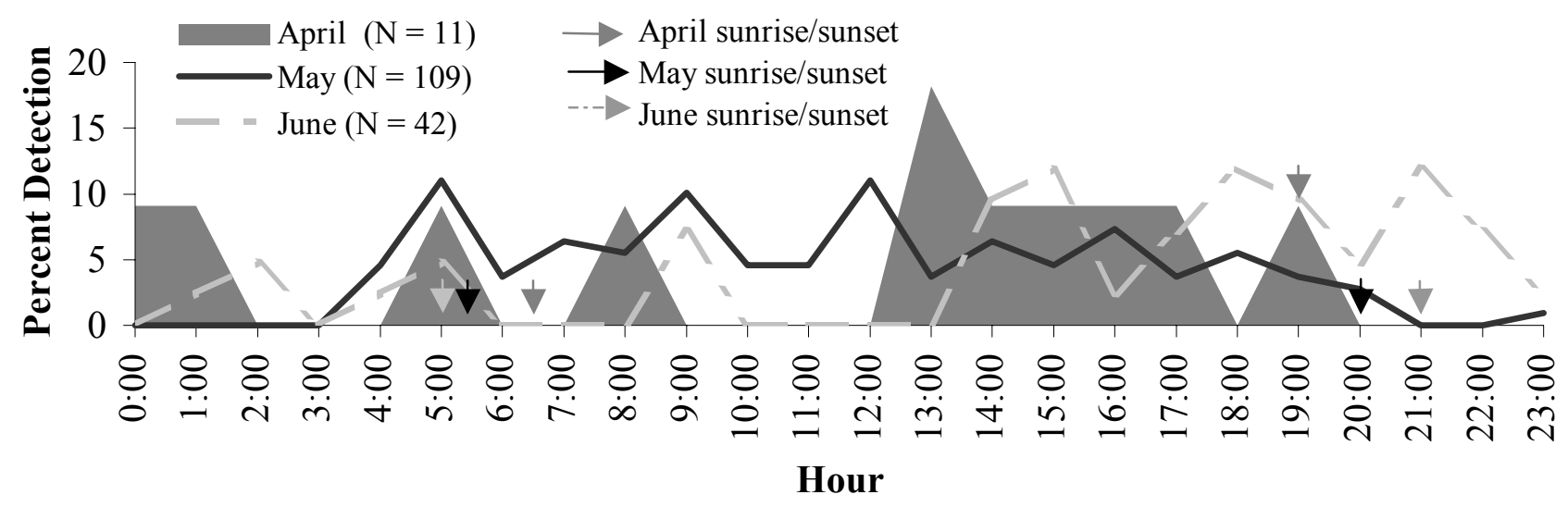

Natural Summer Steelhead

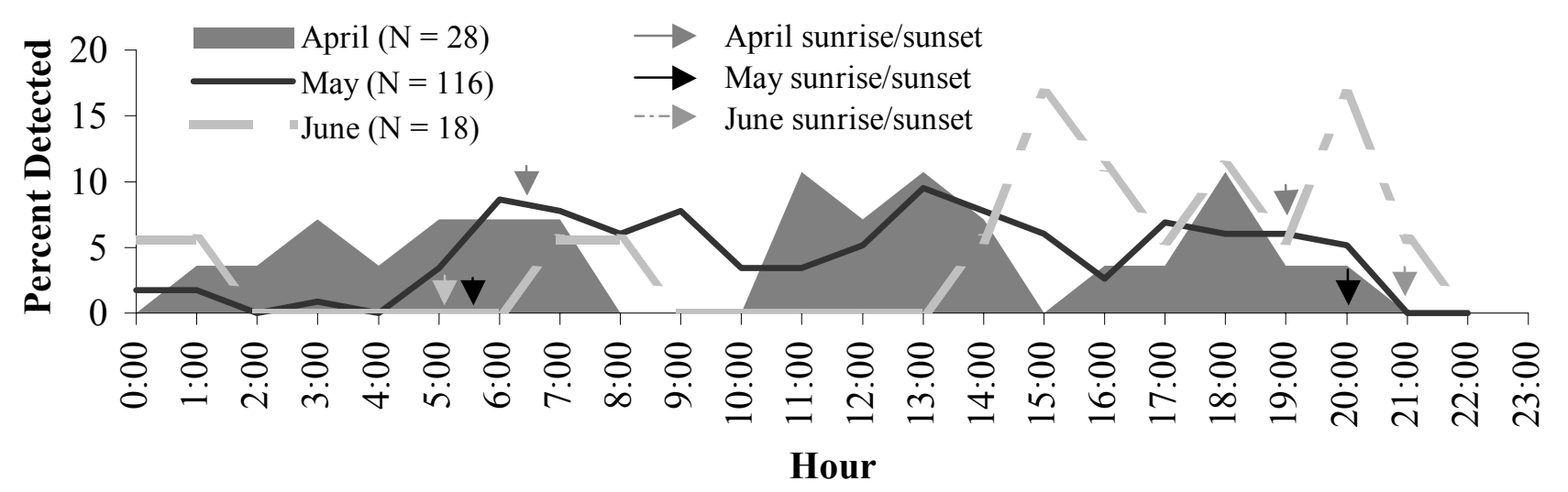

\section{Natural Coho Salmon}

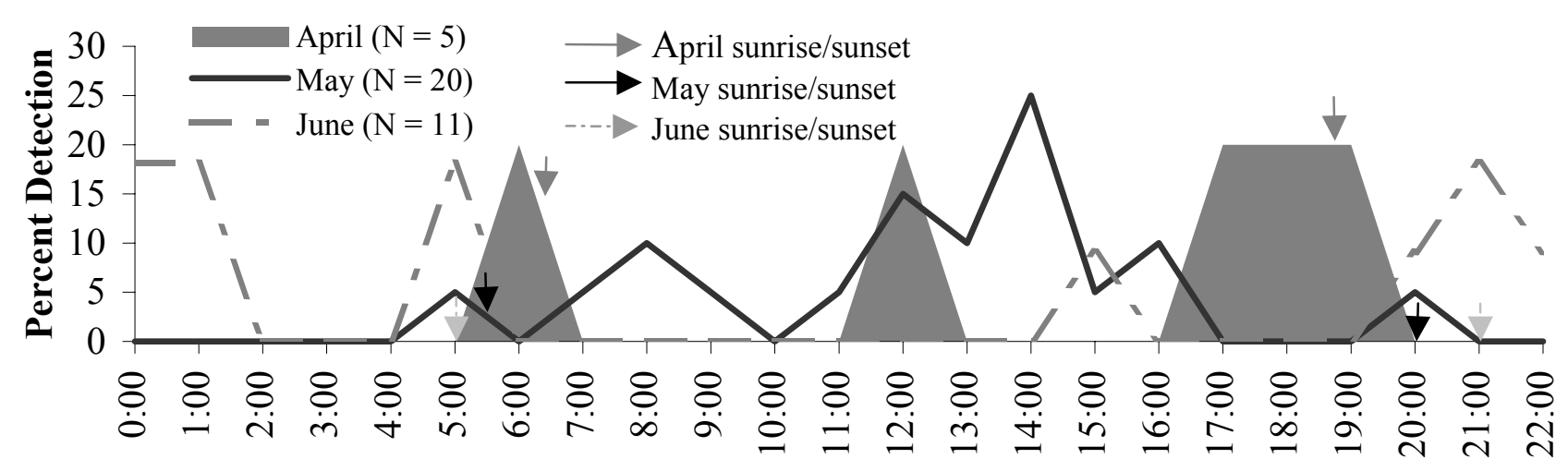

Hour

Figure 12. Diel detection of PIT-tagged hatchery and natural summer steelhead and natural coho salmon at West Extension Canal (RM 3.7), Umatilla River, April - June 2000. 


\section{Spring Chinook Salmon}

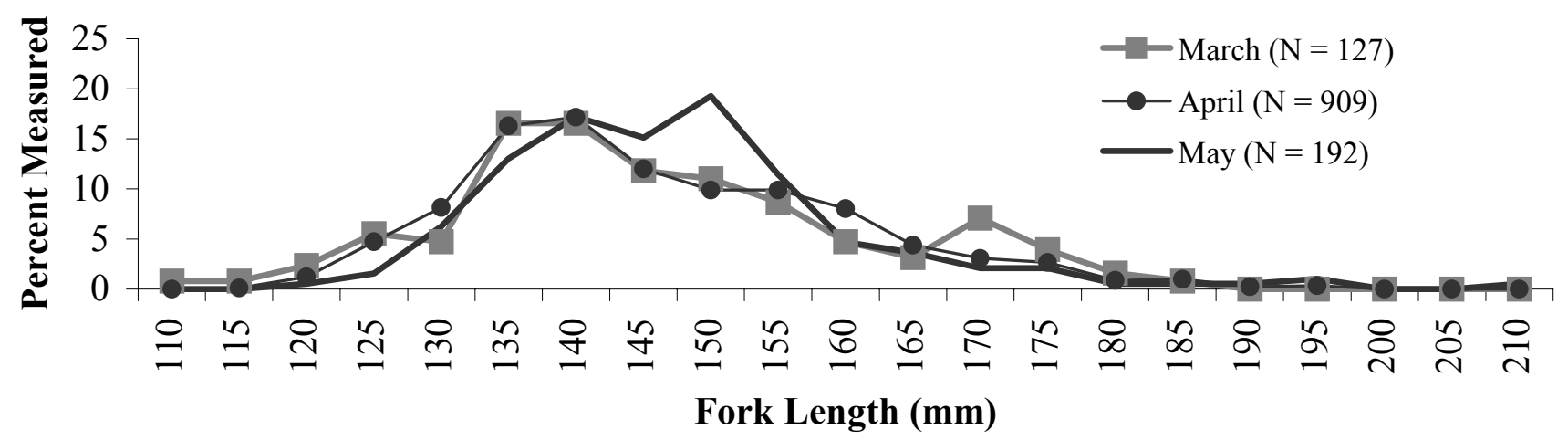

\section{Fall Chinook Salmon}

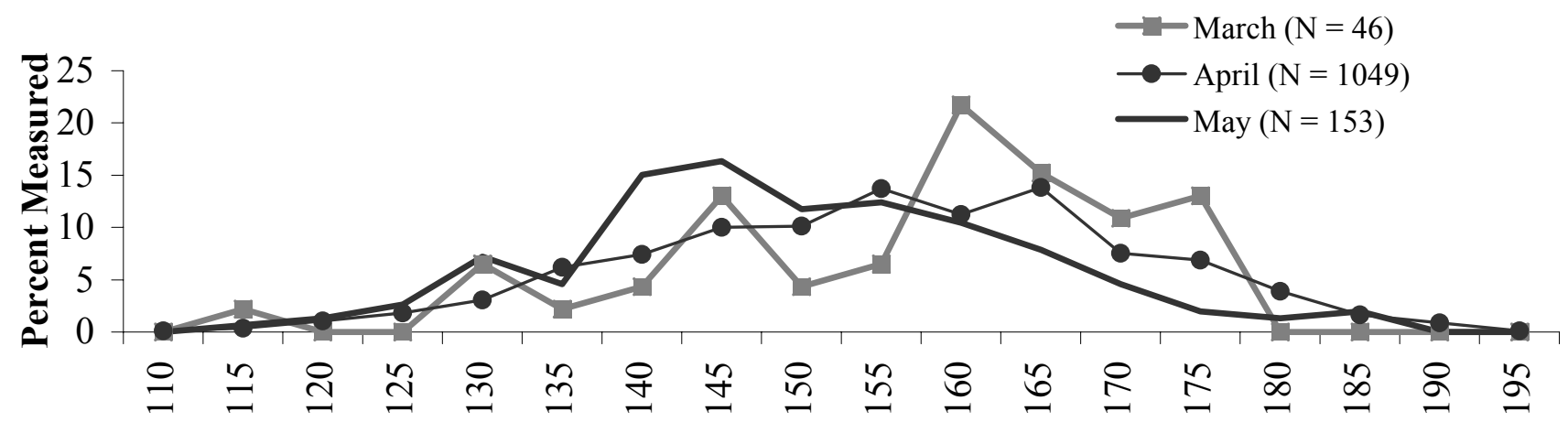

Fork Length (mm)

\section{Chinook Salmon}

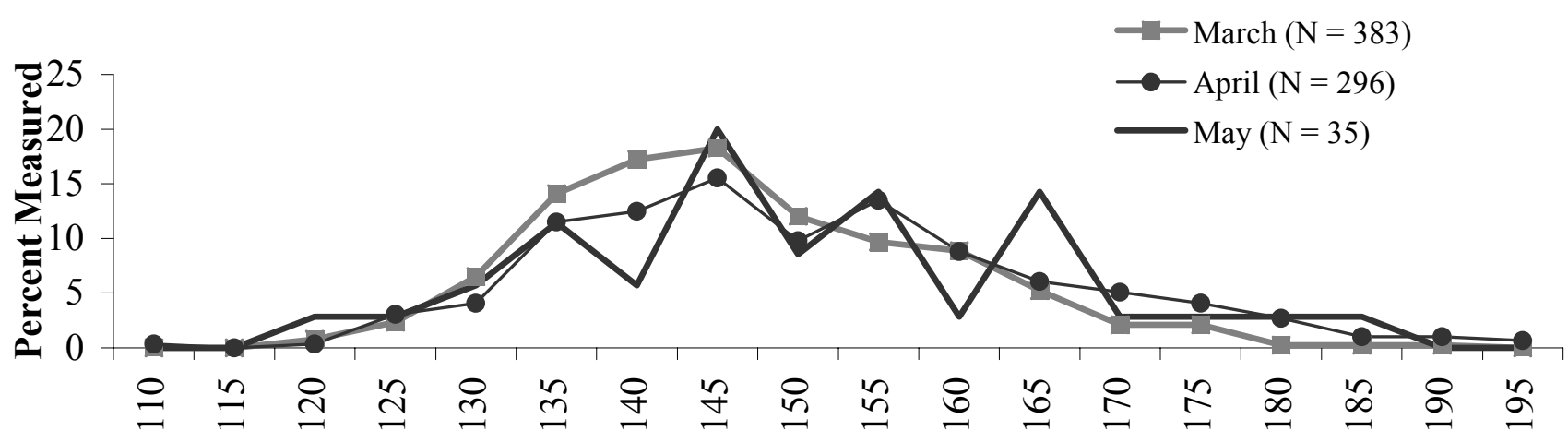

Fork Length (mm)

Figure 13. Length-frequency distribution of hatchery yearling spring and fall chinook salmon and chinook salmon of unknown race captured in the lower Umatilla River, March - May 2000. 


\section{Subyearling Fall Chinook Salmon}

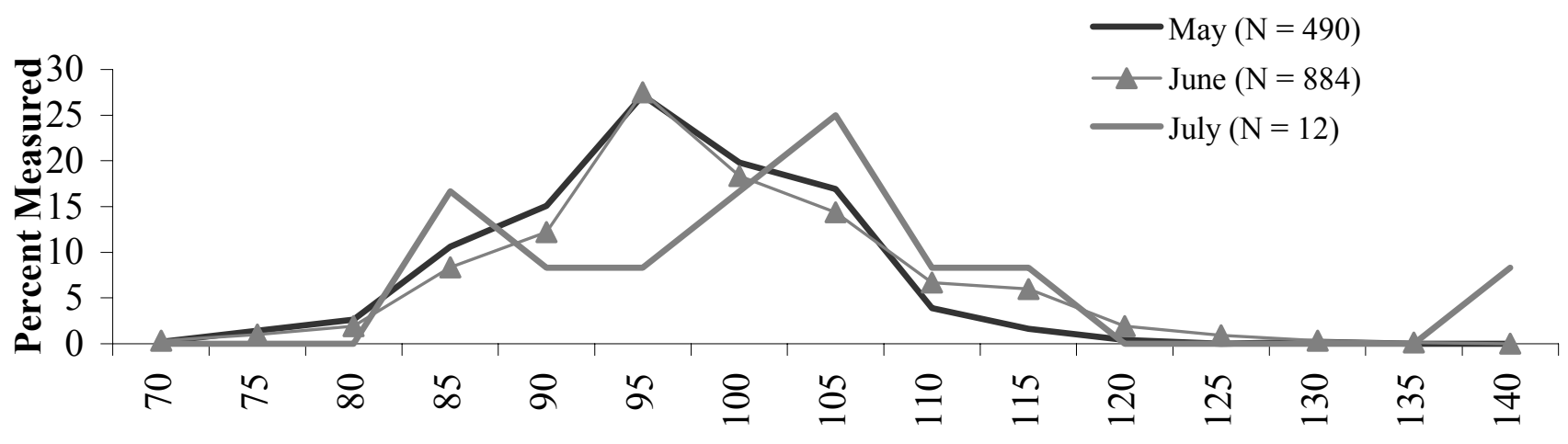

Fork Length (mm)

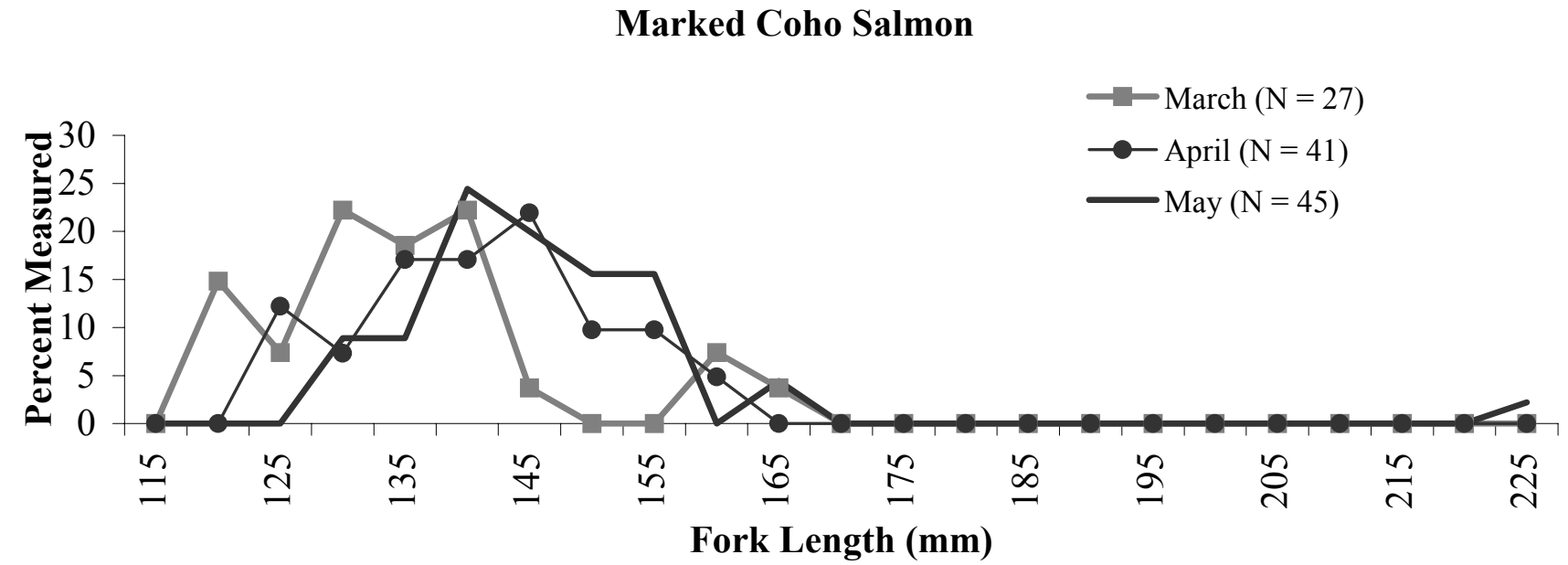

Summer Steelhead

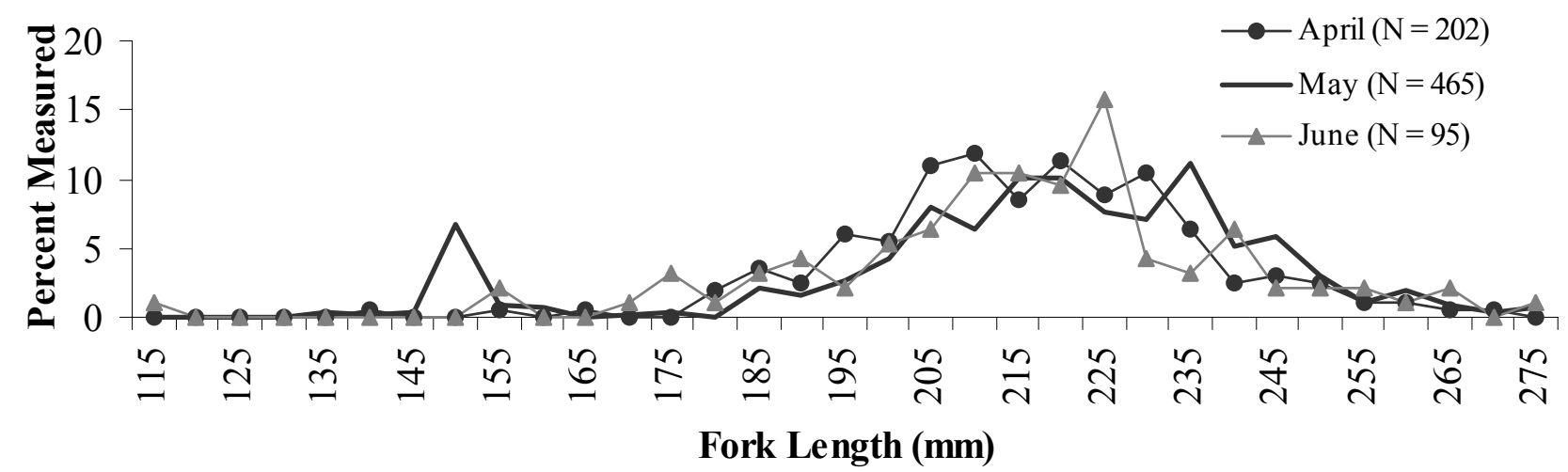

Figure 14. Length-frequency distribution of hatchery subyearling fall chinook salmon, marked (AD-clipped) coho salmon, and hatchery summer steelhead captured in the lower Umatilla River March - July 2000. 


\section{Natural Chinook Salmon}
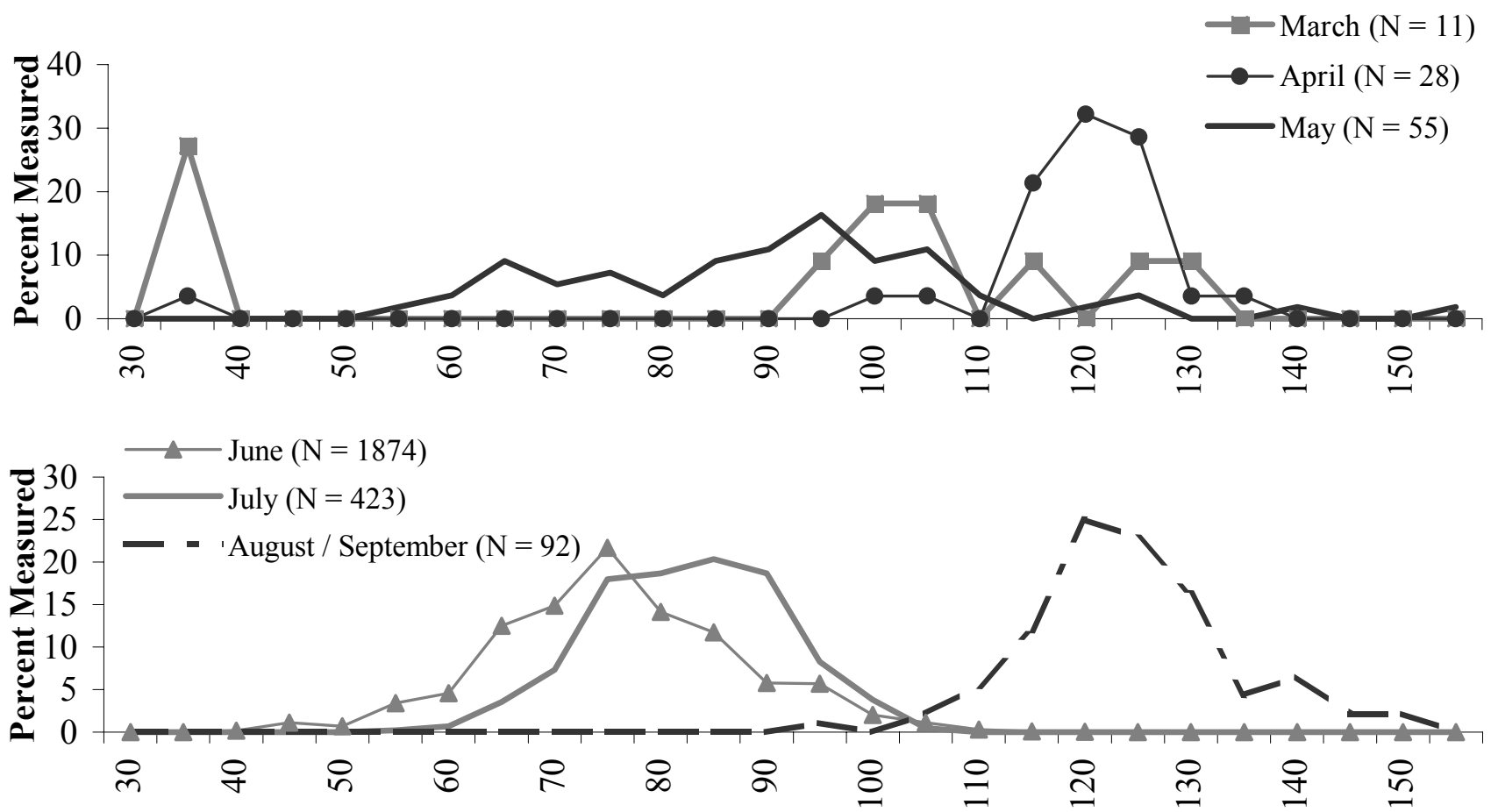

Natural Summer Steelhead

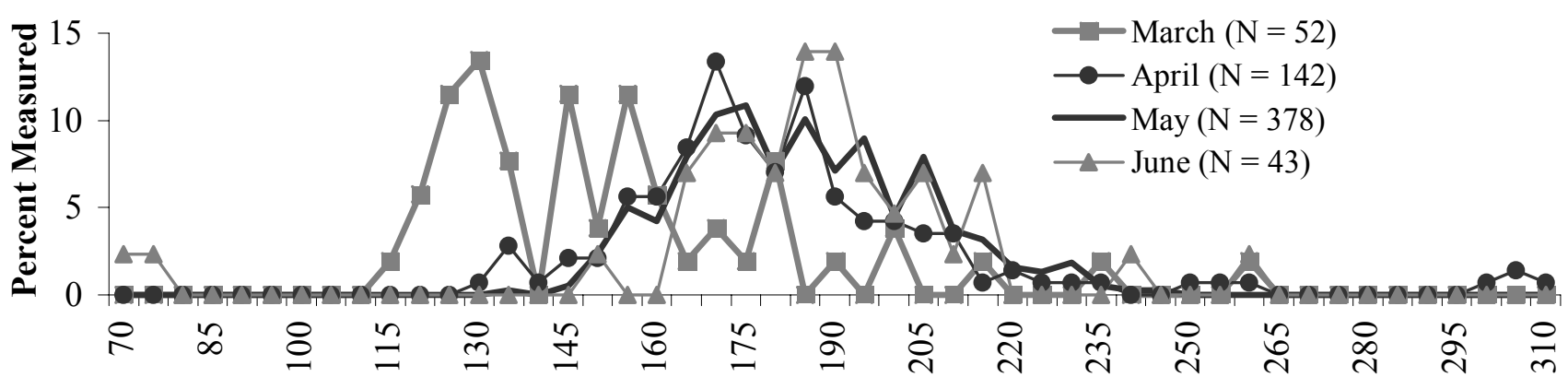

\section{Unmarked Coho Salmon}

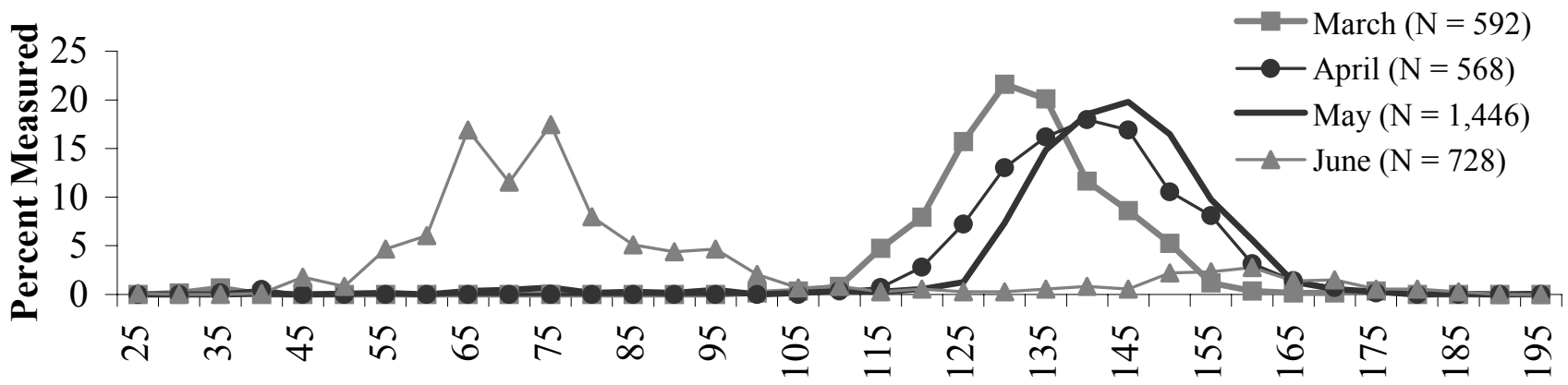

Fork Length (mm)

Figure 15. Length-frequency distribution of natural chinook salmon, natural summer steelhead, and unmarked coho salmon captured in the lower Umatilla River March - September 2000. 

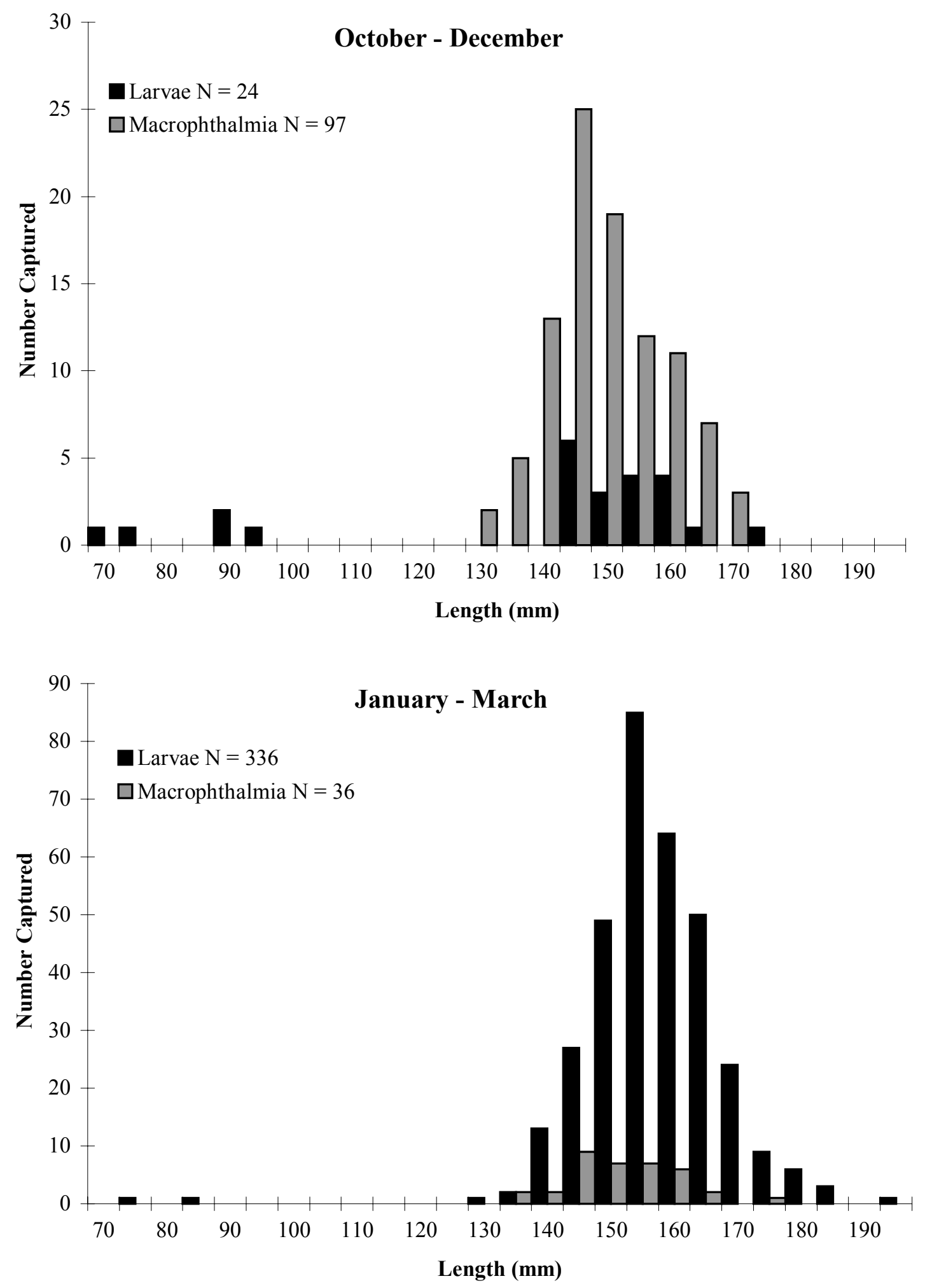

Figure 16. Length-frequency distribution of juvenile Pacific lamprey captured at the rotaryscrew trap (RM 1.2), Umatilla River, October 1999 - March 2000. 


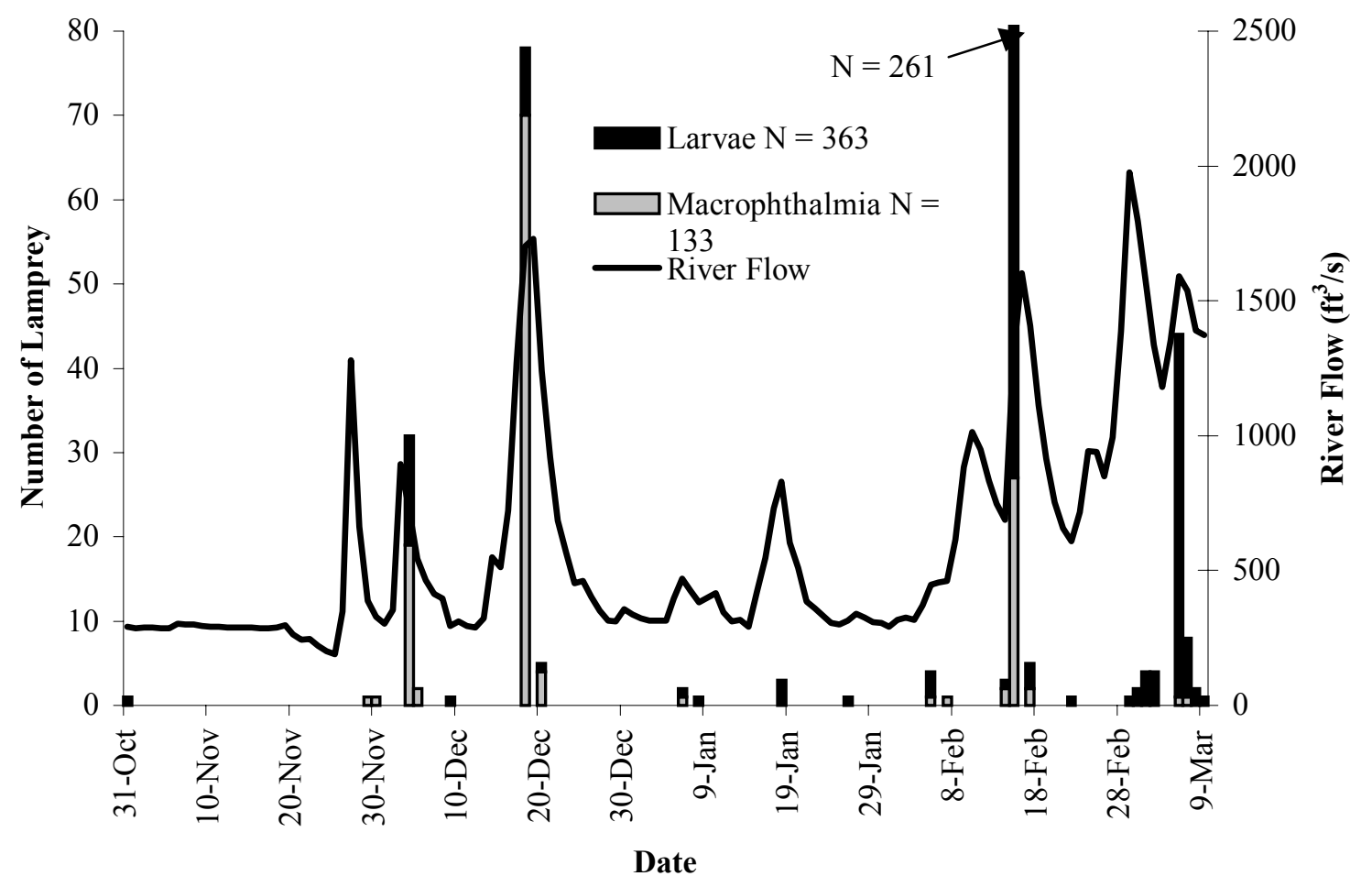

Figure 17. River flow $\left(\mathrm{ft}^{3} / \mathrm{s}\right)$ recorded at the UMAO gauging station (RM 2.1) and number of juvenile Pacific lamprey captured at the rotary-screw trap (RM 1.2), Umatilla River, October 1999 - March 2000. 


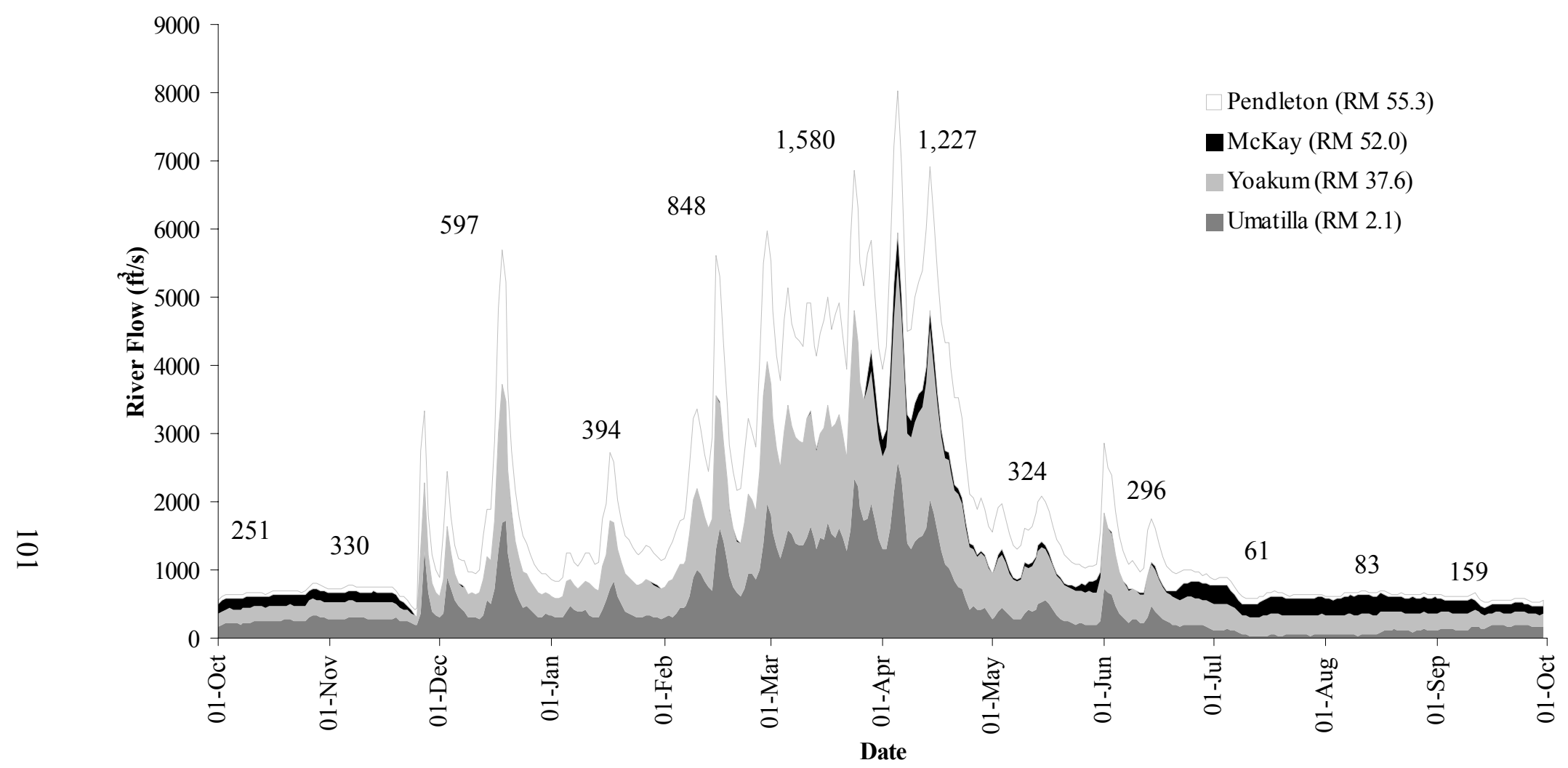

Figure 18. Mean daily river flows $\left(\mathrm{ft}^{3} / \mathrm{s}\right)$ recorded at four gauging stations on the Umatilla River, October 1999 - September 2000. Numbers shown are the monthly means at the UMAO gauging station (RM 2.1). 


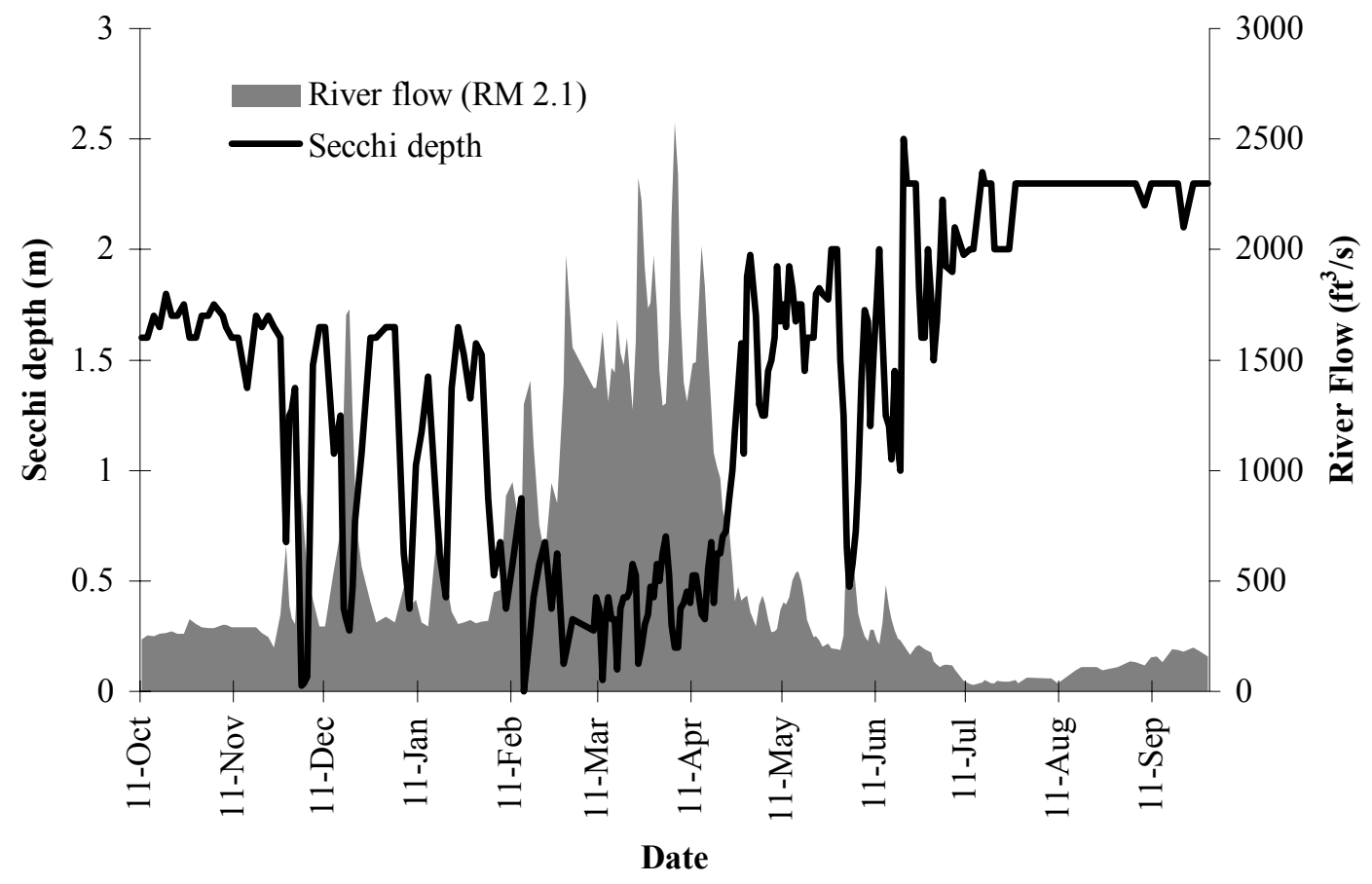

Figure 19. Mean Secchi depth (m) at RM 1.2 or 3.7 plotted against daily river flow $\left(\mathrm{ft}^{3} / \mathrm{s}\right)$ at $\mathrm{RM}$ 2.1, Umatilla River, October 1999 - September 2000.

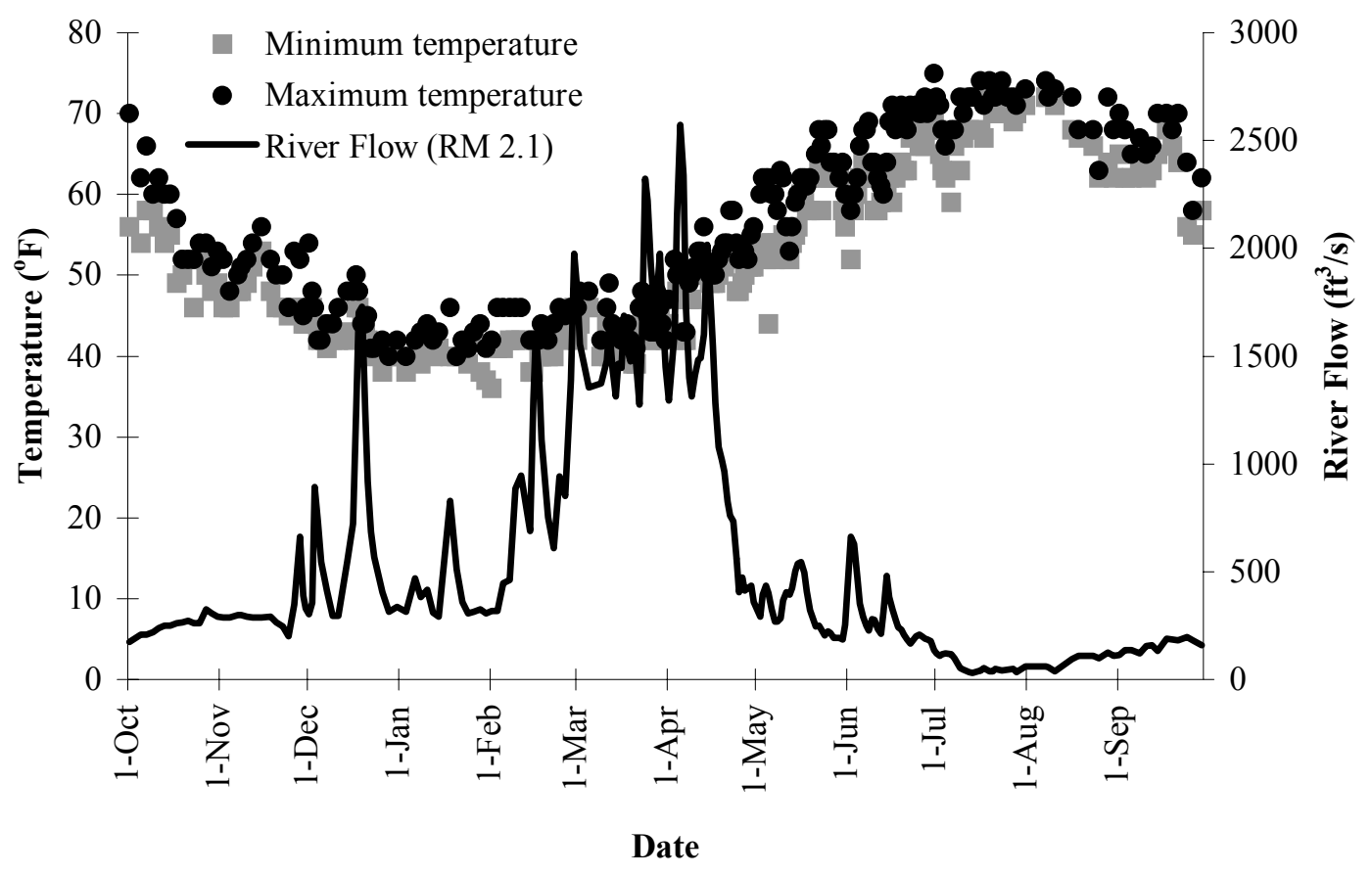

Figure 20. Minimum and maximum water temperature $\left({ }^{\circ} \mathrm{F}\right)$ plotted against river flow $\left(\mathrm{ft}^{3} / \mathrm{s}\right)$ at RM 2.1, Umatilla River, October 1999 - September 2000. 


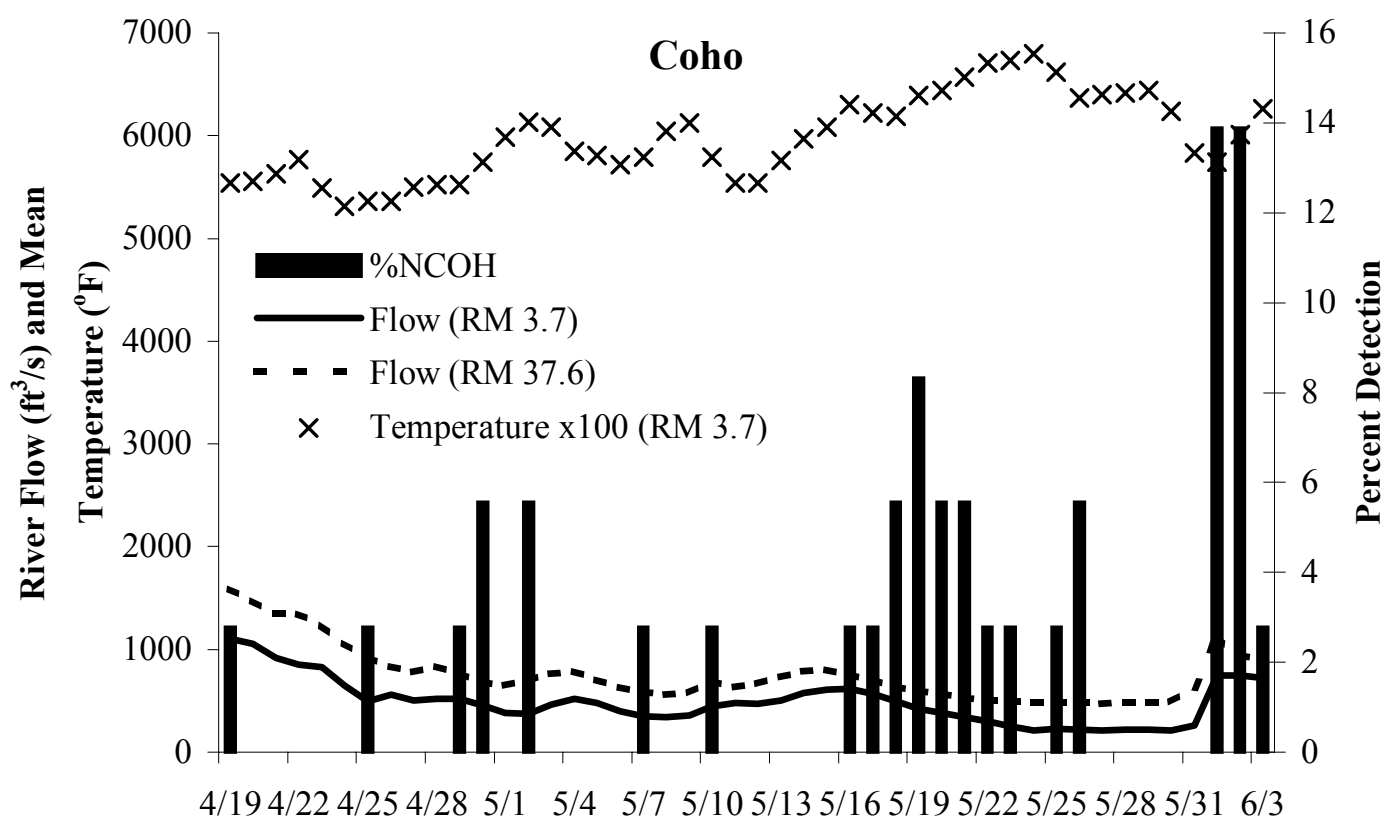

Date

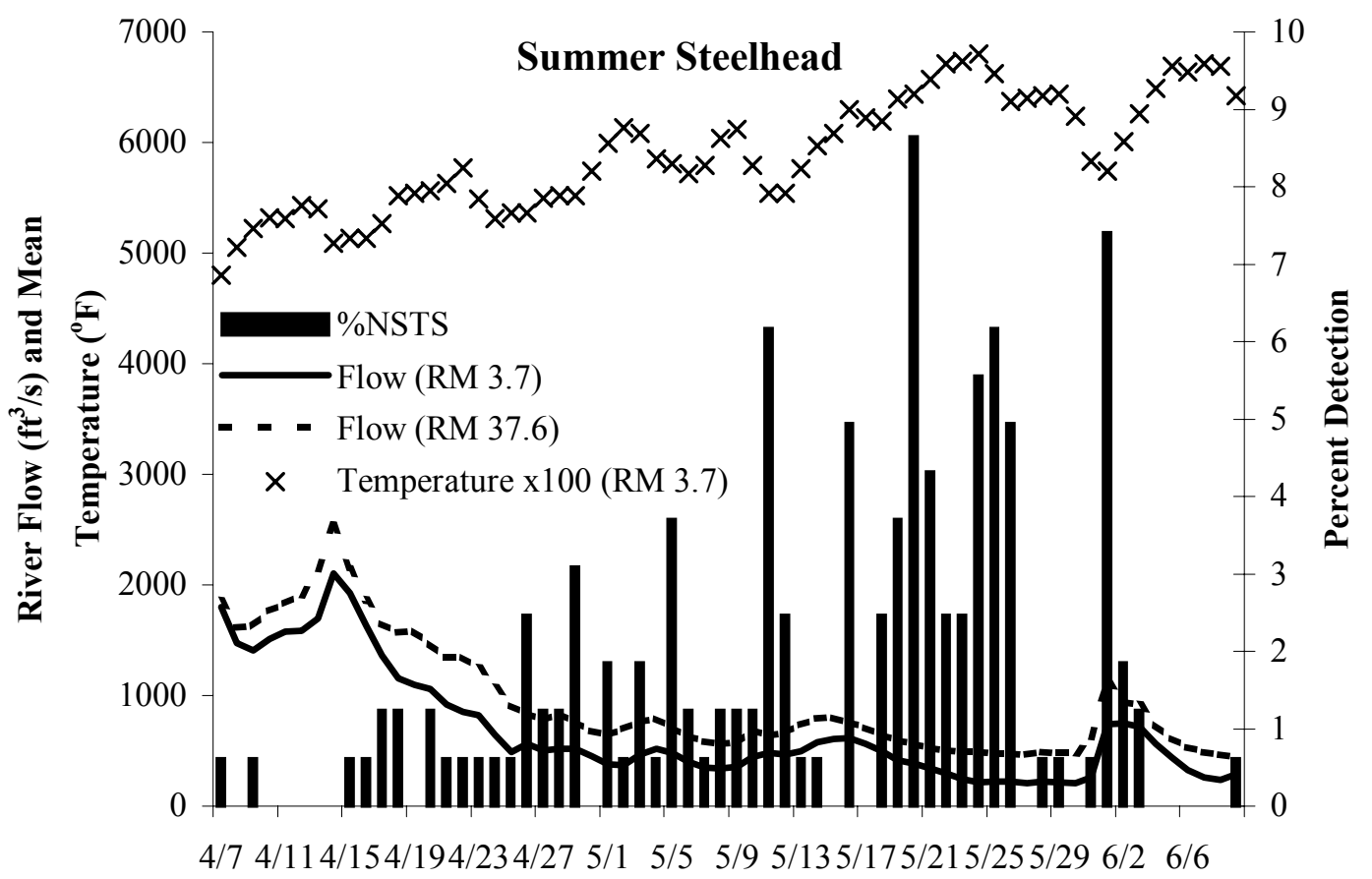

Date

Figure 21. Daily river flow $\left(\mathrm{ft}^{3} / \mathrm{s}\right)$ at $\mathrm{RM} 3.7$ and 37.6 , daily mean temperature $\left({ }^{\circ} \mathrm{F}\right)$ at $\mathrm{RM} 3.7$, and percent detection of natural coho salmon (NCOH) and summer steelhead (NSTS) at West Extension Canal (RM 3.7), Umatilla River, April - June 2000. 


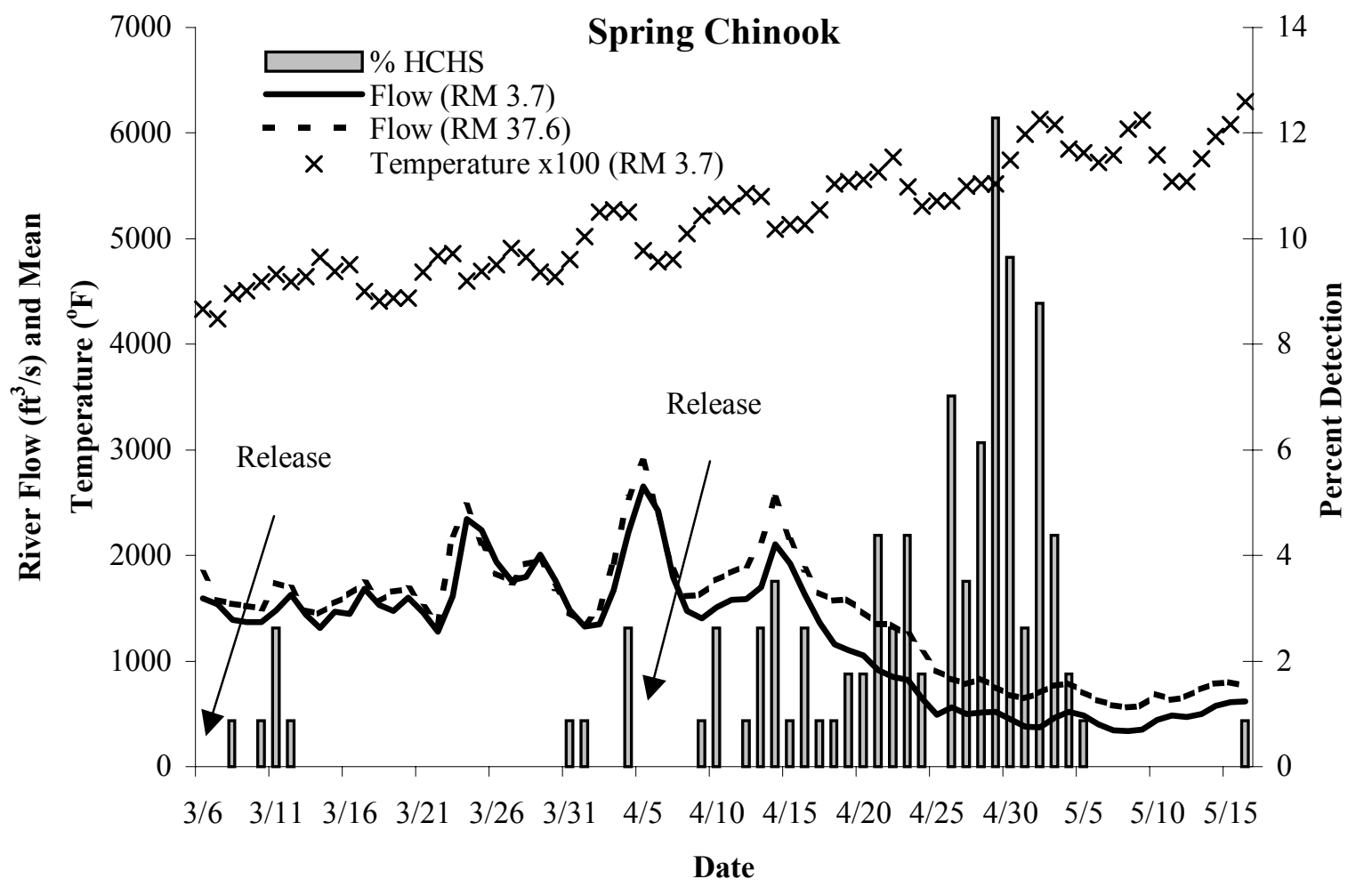

Figure 22. Daily river flow $\left(\mathrm{ft}^{3} / \mathrm{s}\right)$ at $\mathrm{RM} 3.7$ and 37.6 , daily mean temperature $\left({ }^{\circ} \mathrm{F}\right)$ at $\mathrm{RM} 3.7$, and percent detection of hatchery spring chinook salmon (HCHS) at West Extension Canal (RM 3.7), Umatilla River, March - May 2000. 


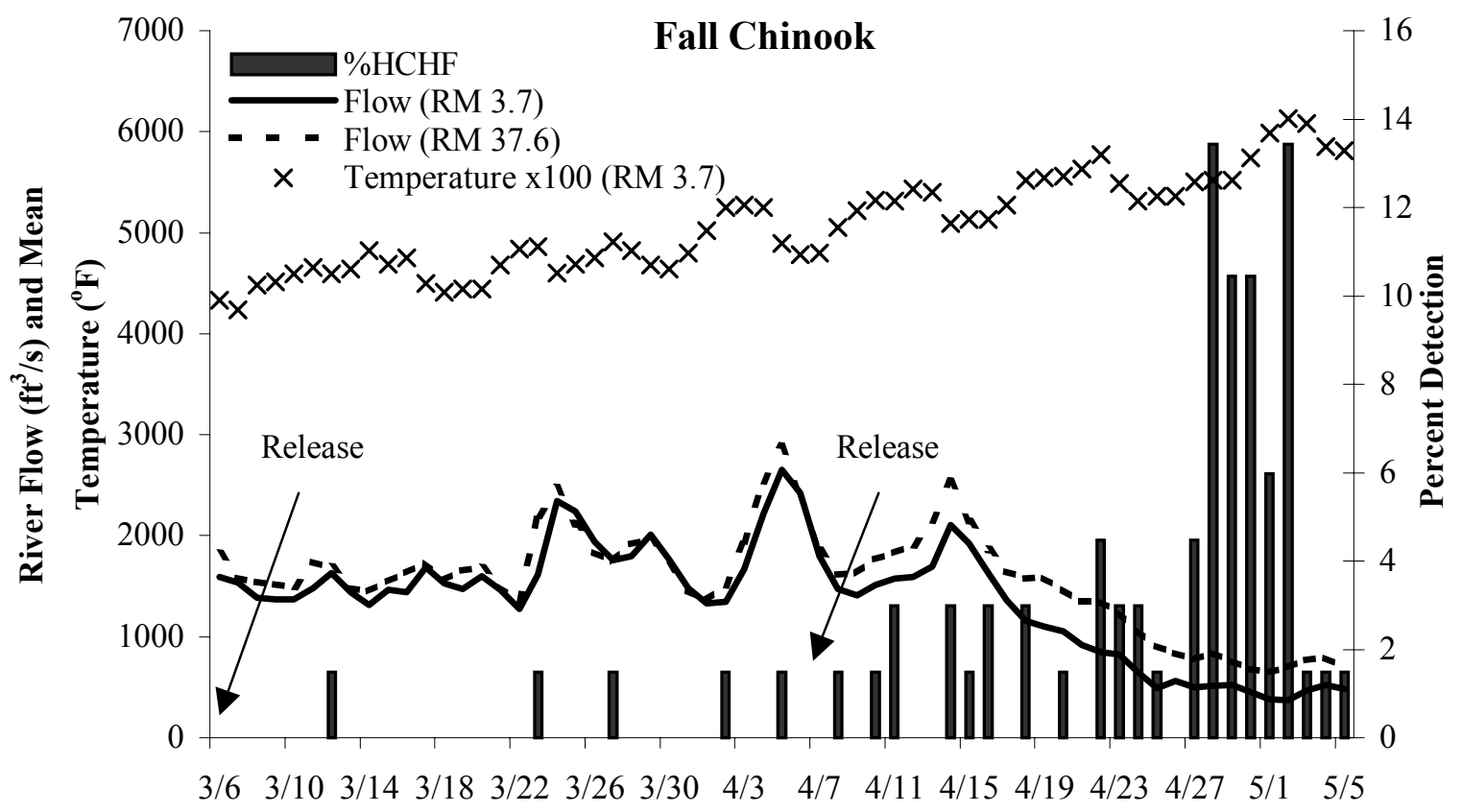

Date

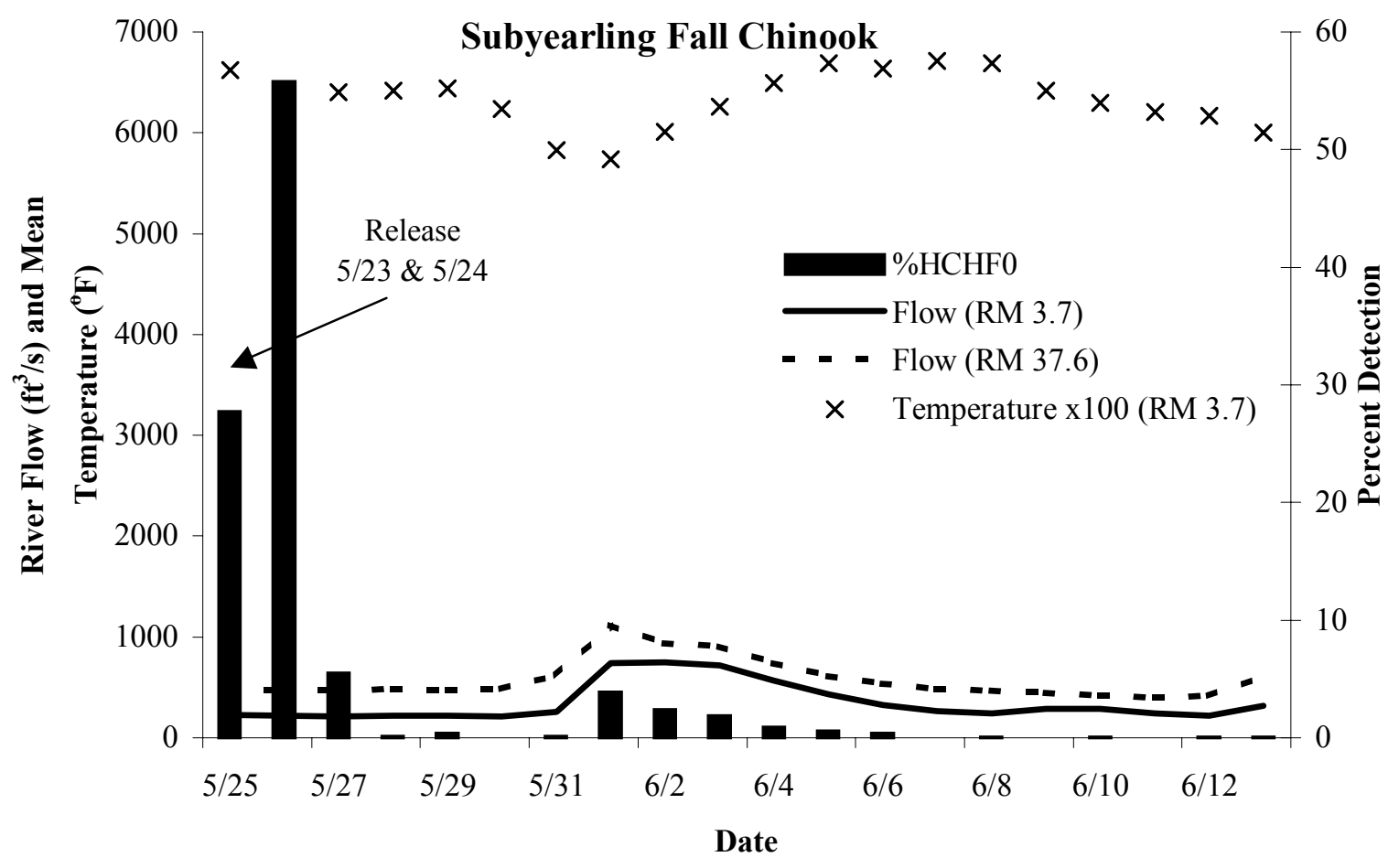

Figure 23. Daily river flow $\left(\mathrm{ft}^{3} / \mathrm{s}\right)$ at $\mathrm{RM} 3.7$ and 37.6 , daily mean temperature $\left({ }^{\circ} \mathrm{F}\right)$ at $\mathrm{RM} 3.7$, and percent detection of hatchery fall (HCHF) and subyearling fall (HCHF0) chinook salmon at West Extension Canal (RM 3.7), Umatilla River, March - June 2000. 

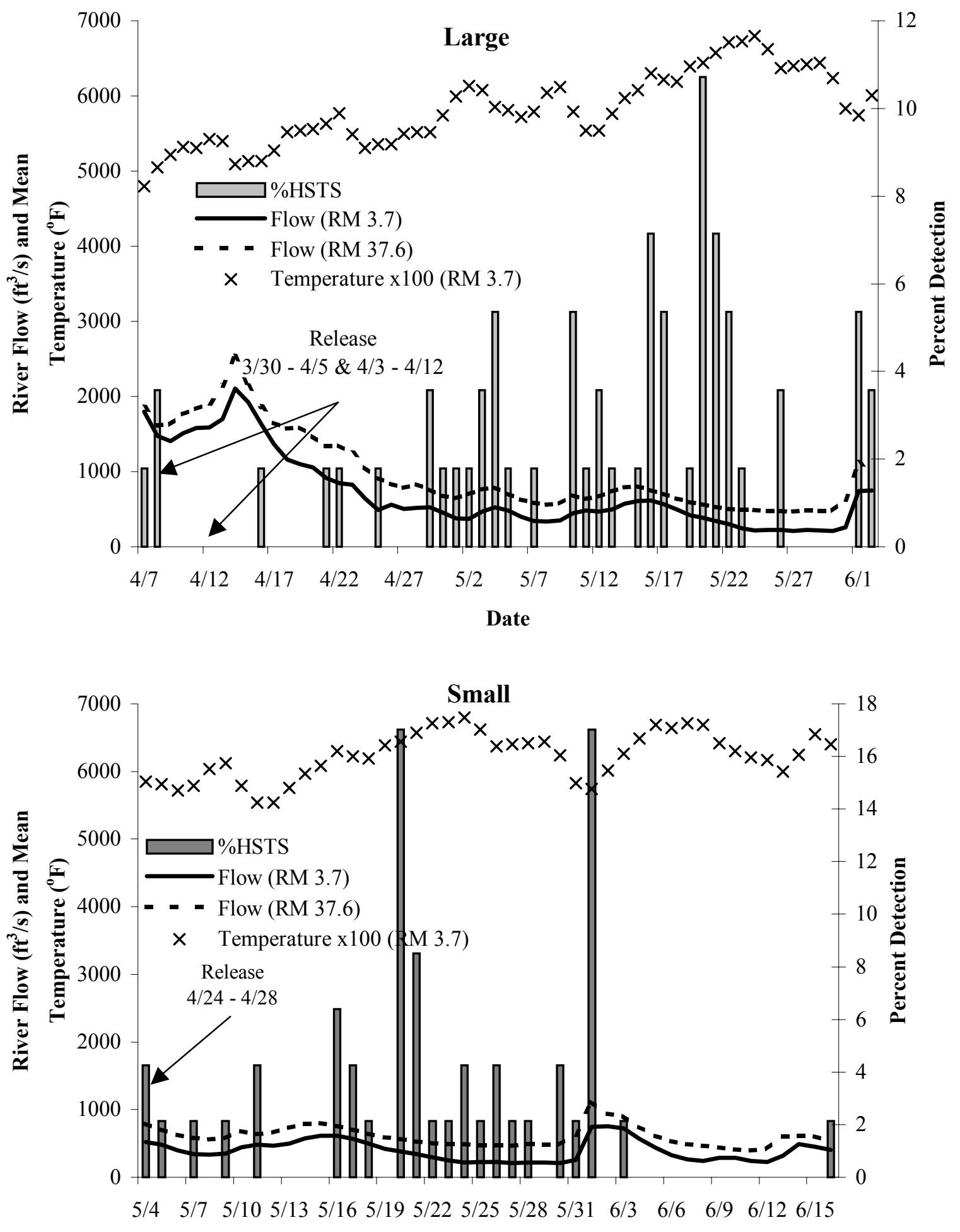

Date

Figure 24. Daily river flow $\left(\mathrm{ft}^{3} / \mathrm{s}\right)$ at $\mathrm{RM} 3.7$ and 37.6 , daily mean temperature $\left({ }^{\circ} \mathrm{F}\right)$ at $\mathrm{RM} 3.7$, and percent detection of large- and small-grade hatchery summer steelhead (HSTS) at West Extension Canal (RM 3.7), Umatilla River, April - June 2000. 


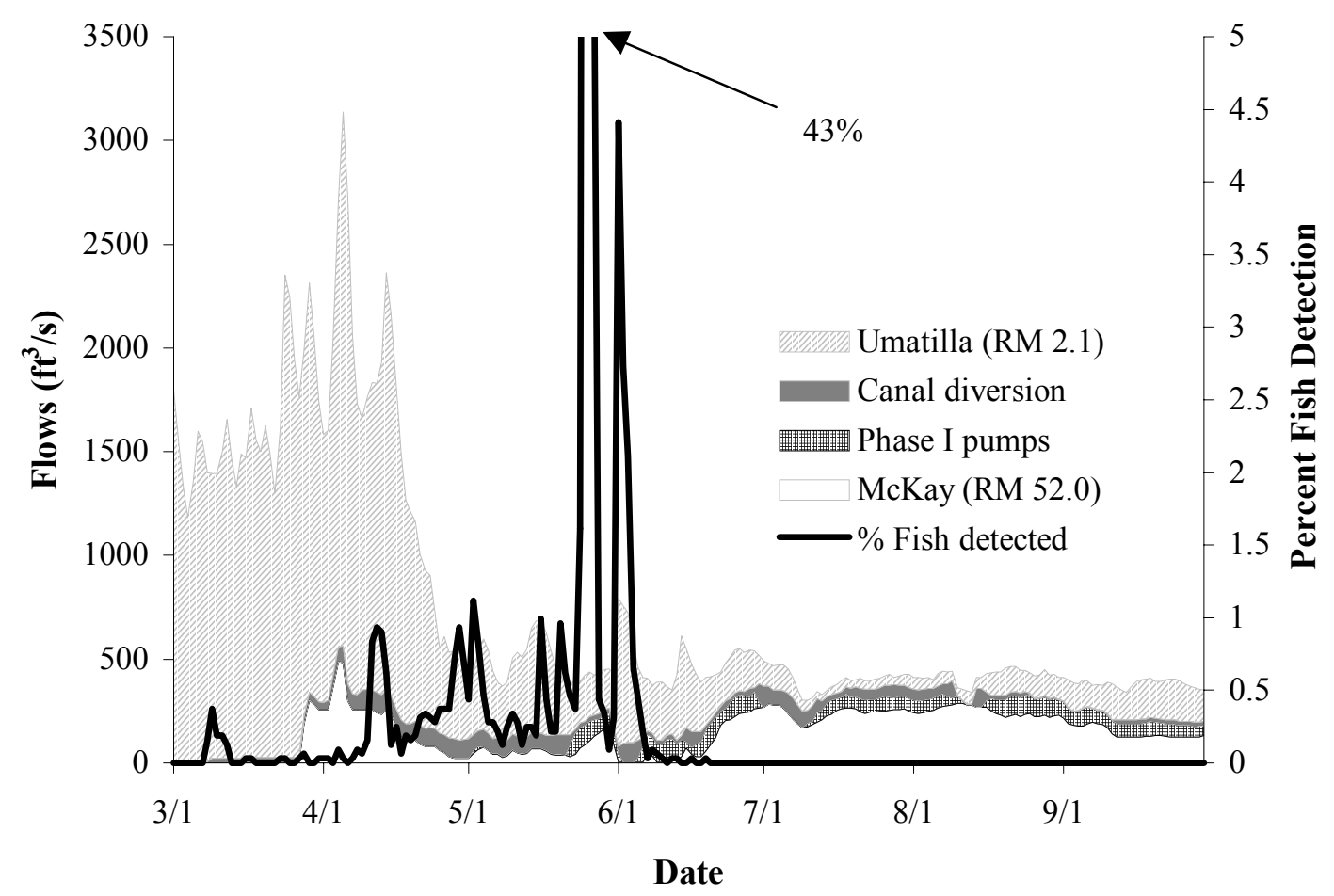

Figure 25. Mean daily river flows $\left(\mathrm{ft}^{3} / \mathrm{s}\right)$ for river discharge at UMAO gauging station (RM 2.1), Phase I exchange pumping, McKay Reservoir water releases, and canal diversion at West Extension Canal (RM 3.7) plotted with total percent detection of hatchery fish, Umatilla River, March - September 2000.

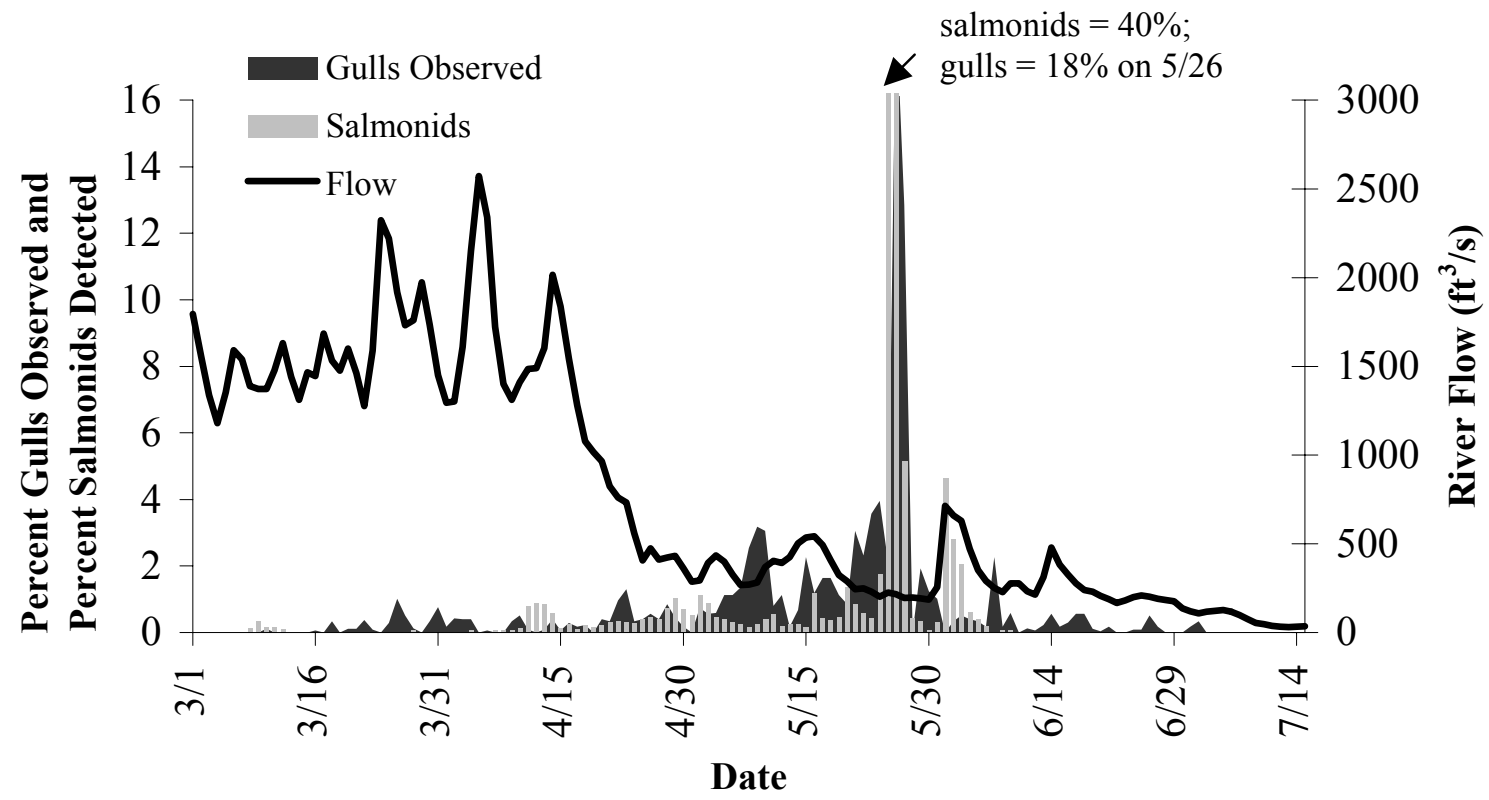

Figure 26. Percent of gulls observed and percent detection of juvenile salmonids at the canal trap (RM 3.7) plotted against river flow $\left(\mathrm{ft}^{3} / \mathrm{s}\right)$, Umatilla River, January - July 2000. Number of gulls observed per day was standardized by the number of observations per day. 


\section{APPENDIX A}

Ancillary Information from Outmigration Studies 
Appendix Table A-1. Detection efficiency of the remote interrogation system at West Extension Canal (RM 3.7), Umatilla River, March - June 2000.

\begin{tabular}{|c|c|c|c|c|c|}
\hline Date & $\begin{array}{c}\text { Water } \\
\text { level - } 1\end{array}$ & $\begin{array}{c}\text { Percent } \\
\text { efficiency - } 1 \\
\end{array}$ & $\begin{array}{c}\text { Water } \\
\text { level - } 2\end{array}$ & $\begin{array}{c}\text { Percent } \\
\text { efficiency - } 2 \\
\end{array}$ & $\begin{array}{c}\text { Total } \\
\text { daily percent } \\
\text { efficiency }\end{array}$ \\
\hline $3 / 17$ & & & -- & $133.33^{a}$ & 133.33 \\
\hline $3 / 18$ & & & -- & $116.67^{a}$ & 116.67 \\
\hline $3 / 19$ & -- & $100.00^{a}$ & & & 100.00 \\
\hline $3 / 21$ & -- & $100.00^{a}$ & & & 100.00 \\
\hline $3 / 22$ & -- & $100.00^{a}$ & & & 100.00 \\
\hline $3 / 23$ & -- & $133.33^{a}$ & & & 133.33 \\
\hline $3 / 25$ & 0.75 & 50.00 & & & 50.00 \\
\hline $3 / 28$ & 0.75 & 150.00 & 1.00 & 133.33 & 141.67 \\
\hline $3 / 29$ & -- & $80.00^{a}$ & 1.00 & 141.67 & 123.53 \\
\hline $4 / 1$ & 0.75 & 116.67 & & & 116.67 \\
\hline $4 / 2$ & 0.50 & 116.67 & 0.75 & 116.67 & 116.67 \\
\hline $4 / 3$ & 0.25 & 141.67 & & & 141.67 \\
\hline $4 / 13$ & 0.75 & 141.67 & & & 141.67 \\
\hline $4 / 15$ & 0.25 & 133.33 & & & 133.33 \\
\hline $4 / 16$ & 0.75 & 133.33 & & & 133.33 \\
\hline $4 / 17$ & 0.25 & 166.67 & & & 166.67 \\
\hline $4 / 25$ & 0.50 & 191.67 & & & 191.67 \\
\hline $4 / 26$ & 1.00 & 158.33 & & & 158.33 \\
\hline $4 / 28$ & 1.00 & 133.33 & & & 133.33 \\
\hline $4 / 29$ & 1.00 & 100.00 & 0.75 & 100.00 & 100.00 \\
\hline $4 / 30$ & 0.75 & 100.00 & & & 100.00 \\
\hline $5 / 3$ & 0.75 & 100.00 & & & 100.00 \\
\hline $5 / 5$ & 1.00 & 100.00 & & & 100.00 \\
\hline $5 / 7$ & 1.00 & 116.67 & & & 116.67 \\
\hline $5 / 9$ & 1.00 & 216.67 & 0.75 & 108.33 & 162.50 \\
\hline $5 / 11$ & 0.25 & 83.33 & 1.00 & 100.00 & 91.67 \\
\hline $5 / 12$ & 0.50 & 100.00 & & & 100.00 \\
\hline $5 / 14$ & 1.00 & 91.67 & 1.00 & 91.67 & 91.67 \\
\hline $5 / 15$ & 0.50 & 100.00 & & & 100.00 \\
\hline $5 / 16$ & 0.50 & 100.00 & & & 100.00 \\
\hline $5 / 21$ & 1.00 & 100.00 & & & 100.00 \\
\hline $5 / 22$ & 0.50 & 100.00 & & & 100.00 \\
\hline $5 / 23$ & 1.00 & 100.00 & & & 100.00 \\
\hline $5 / 26$ & 0.25 & 91.67 & & & 91.67 \\
\hline $5 / 29$ & 0.50 & $100.00^{a}$ & & & 100.00 \\
\hline $5 / 31$ & -- & 100.00 & & & 100.00 \\
\hline $6 / 3$ & 0.50 & 100.00 & & & 100.00 \\
\hline $6 / 4$ & 0.50 & 100.00 & & & 100.00 \\
\hline
\end{tabular}

a Test was conducted from the outside of bypass flume. 
Appendix Table A-1. Continued.

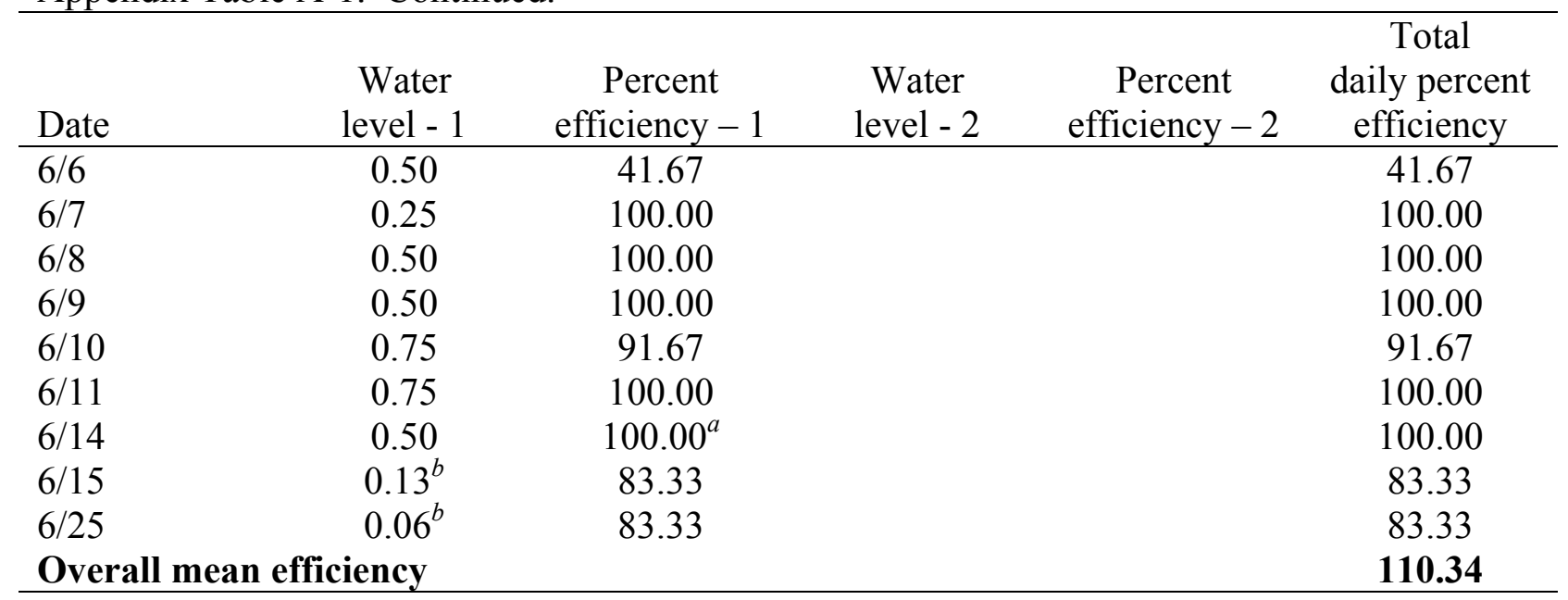

$b$ Test was conducted while the trap was in sample mode. 
Appendix Table A-2. Detection and travel time by replicate group of PIT-tagged fish released for reach-specific survival tests and interrogated in the lower Umatilla River and at Columbia River interrogation and recovery sites, March - July 2000. Duplicate detections were removed from the count but not from travel time analysis.

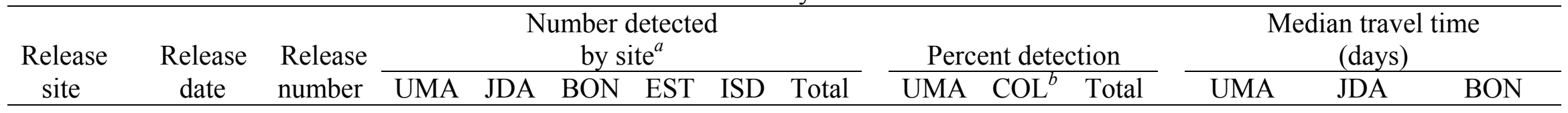

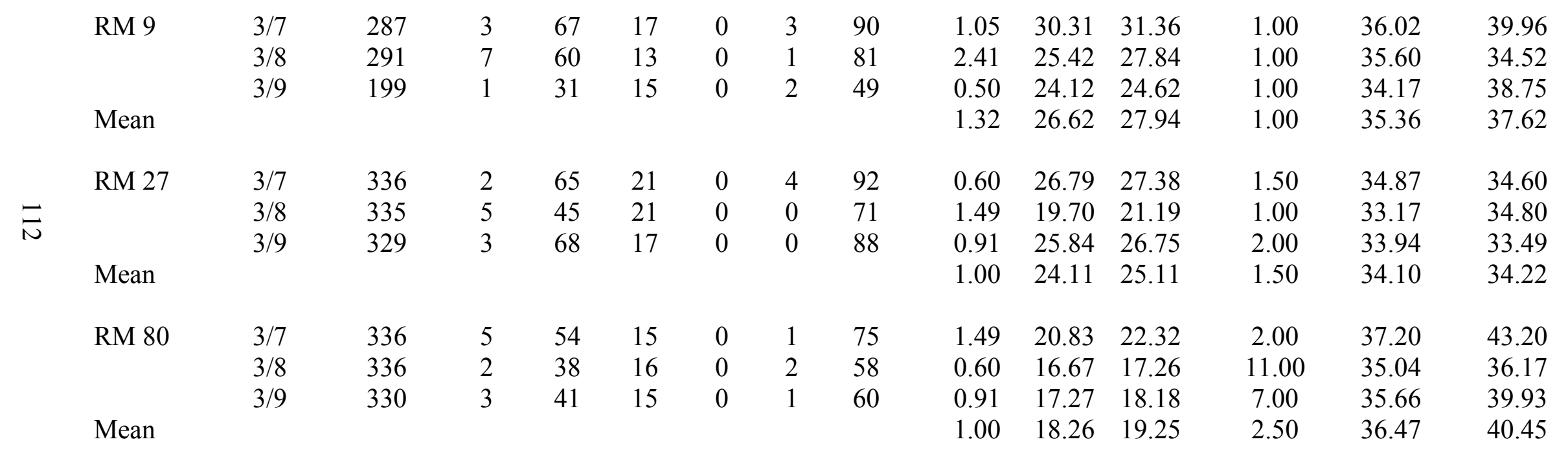

Subyearling Fall Chinook Salmon

\begin{tabular}{|c|c|c|c|c|c|c|c|c|c|c|c|c|c|c|}
\hline RM 0 & $5 / 23$ & 650 & 0 & 71 & 25 & 0 & 12 & 108 & - & 16.62 & 16.62 & - & 14.08 & 16.94 \\
\hline & $5 / 24$ & 650 & 0 & 68 & 20 & 0 & 12 & 100 & - & 15.38 & 15.38 & - & 15.37 & 17.57 \\
\hline & $5 / 25$ & 592 & 0 & 59 & 18 & 0 & 12 & 89 & - & 15.03 & 15.03 & - & 13.63 & 18.59 \\
\hline Mean & & & & & & & & & - & 15.68 & 15.68 & - & 14.16 & 17.93 \\
\hline
\end{tabular}

a UMA = Three Mile Falls Dam on the Umatilla River, JDA = John Day Dam, BON = Bonneville Dam, EST = Columbia River estuary, ISD = Columbia River islands with bird colonies

${ }^{b} \quad C O L=$ total percent detection from the Columbia River (JDA, BON, EST, and ISD) 
Appendix Table A-2. Continued.

\begin{tabular}{|c|c|c|c|c|c|c|c|c|c|c|c|c|c|c|}
\hline \multirow{2}{*}{$\begin{array}{l}\text { Release } \\
\text { site }\end{array}$} & \multirow{2}{*}{$\begin{array}{c}\text { Release } \\
\text { date }\end{array}$} & \multirow{2}{*}{$\begin{array}{l}\text { Release } \\
\text { number }\end{array}$} & \multicolumn{6}{|c|}{$\begin{array}{l}\text { Number detected } \\
\text { by site }{ }^{a}\end{array}$} & \multicolumn{3}{|c|}{ Percent detection } & \multicolumn{3}{|c|}{$\begin{array}{l}\text { Median travel time } \\
\text { (days) }\end{array}$} \\
\hline & & & UMA & JDA & BON & EST & ISD & Total & UMA & $\mathrm{COL}^{b}$ & Total & UMA & JDA & BON \\
\hline \multicolumn{15}{|c|}{ Subyearling Fall Chinook Salmon } \\
\hline \multirow[t]{3}{*}{ RM 9} & $5 / 23$ & 200 & 71 & 6 & 0 & 0 & 0 & 77 & 35.50 & 3.00 & 38.50 & 0.98 & 16.36 & 21.48 \\
\hline & $5 / 24$ & 201 & 46 & 7 & 5 & 1 & 2 & 61 & 22.89 & 7.46 & 30.35 & 0.94 & 19.24 & 15.33 \\
\hline & $5 / 25$ & 195 & 60 & 14 & 10 & 0 & 4 & 88 & 30.77 & 14.36 & 45.13 & 0.62 & 13.52 & 15.72 \\
\hline Mean & & & & & & & & & 29.72 & 8.27 & 37.99 & 0.85 & 15.71 & 15.72 \\
\hline \multirow[t]{3}{*}{ RM 27} & $5 / 23$ & 149 & 39 & 7 & 2 & 0 & 0 & 48 & 26.17 & 6.04 & 32.21 & 1.99 & 13.50 & 18.27 \\
\hline & $5 / 24$ & 150 & 30 & 4 & 4 & 0 & 1 & 39 & 20.00 & 6.00 & 26.00 & 1.71 & 15.35 & 17.50 \\
\hline & $5 / 25$ & 147 & 57 & 10 & 3 & 0 & 3 & 73 & 38.78 & 10.88 & 49.66 & 1.27 & 13.79 & 18.40 \\
\hline Mean & & & & & & & & & 28.32 & 7.64 & 35.96 & 1.69 & 14.37 & 18.31 \\
\hline \multirow[t]{4}{*}{ RM 56} & $5 / 23$ & 150 & 29 & 8 & 3 & 0 & 0 & 40 & 19.33 & 7.33 & 26.67 & 2.65 & 13.51 & 18.73 \\
\hline & $5 / 24$ & 150 & 49 & 5 & 3 & 0 & 0 & 57 & 32.67 & 5.33 & 38.00 & 2.27 & 13.68 & 21.50 \\
\hline & $5 / 25$ & 148 & 43 & 2 & 1 & 0 & 4 & 50 & 29.05 & 4.73 & 33.78 & 7.49 & 14.79 & 20.76 \\
\hline & & & & & & & & & 27.02 & 5.80 & 32.82 & 3.00 & 14.11 & 19.04 \\
\hline \multirow[t]{5}{*}{ RM 73.5} & $5 / 23$ & 150 & 47 & 10 & 1 & 0 & 1 & 59 & 31.33 & 8.00 & 39.33 & 2.77 & 13.11 & 16.75 \\
\hline & $5 / 24$ & 150 & 26 & 3 & 0 & 0 & 1 & 30 & 17.33 & 2.67 & 20.00 & 8.61 & 15.74 & 20.23 \\
\hline & $5 / 25$ & 147 & 25 & 0 & 1 & 0 & 1 & 27 & 17.01 & 1.36 & 18.37 & 7.77 & 14.06 & 31.70 \\
\hline & & & & & & & & & 21.89 & 4.01 & 25.90 & 7.58 & 14.45 & 20.23 \\
\hline & \multicolumn{14}{|c|}{ Summer Steelhead } \\
\hline \multirow[t]{3}{*}{ RM 9} & $4 / 10$ & 142 & 30 & 3 & 6 & 0 & 3 & 42 & 21.13 & 8.45 & 29.58 & 11.82 & 26.40 & 28.44 \\
\hline & $4 / 11$ & 144 & 47 & 6 & 1 & 0 & 3 & 57 & 32.64 & 6.94 & 39.58 & 1.50 & 13.35 & 18.66 \\
\hline & $4 / 12$ & 97 & 30 & 2 & 3 & 0 & 3 & 38 & 30.93 & 8.25 & 39.18 & 1.07 & 12.70 & 21.48 \\
\hline Mean & & & & & & & & & 28.23 & 7.88 & 36.11 & 1.52 & 17.32 & 24.76 \\
\hline
\end{tabular}


Appendix Table A-2. Continued.

\begin{tabular}{|c|c|c|c|c|c|c|c|c|c|c|c|c|c|c|}
\hline \multirow{2}{*}{$\begin{array}{c}\text { Release } \\
\text { site }\end{array}$} & \multirow{2}{*}{$\begin{array}{c}\text { Release } \\
\text { date }\end{array}$} & \multirow{2}{*}{$\begin{array}{l}\text { Release } \\
\text { number }\end{array}$} & \multicolumn{6}{|c|}{$\begin{array}{l}\text { Number detected } \\
\text { by site }{ }^{a}\end{array}$} & \multicolumn{3}{|c|}{ Percent detection } & \multicolumn{3}{|c|}{$\begin{array}{l}\text { Median travel time } \\
\text { (days) }\end{array}$} \\
\hline & & & UMA & JDA & $\mathrm{BON}$ & EST & ISD & Total & UMA & $\mathrm{COL}^{b}$ & Total & UMA & JDA & $\mathrm{BON}$ \\
\hline \multirow[t]{3}{*}{ RM 27} & $4 / 10$ & 137 & 27 & 5 & 4 & 0 & 0 & 36 & 19.71 & 6.57 & 26.28 & 21.75 & 24.20 & 25.38 \\
\hline & $4 / 11$ & 145 & 21 & 4 & 7 & 0 & 9 & 41 & 14.48 & 13.79 & 28.28 & 19.48 & 17.37 & 20.60 \\
\hline & $4 / 12$ & 99 & 27 & 6 & 4 & 0 & 3 & 40 & 27.27 & 13.13 & 40.40 & 20.81 & 19.47 & 25.17 \\
\hline Mean & & & & & & & & & 20.49 & 11.16 & 31.65 & 20.81 & 21.25 & 24.75 \\
\hline \multirow[t]{3}{*}{ RM 48} & $4 / 10$ & 178 & 20 & 4 & 1 & 0 & 1 & 26 & 11.24 & 3.37 & 14.61 & 22.32 & 14.11 & 18.62 \\
\hline & $4 / 11$ & 193 & 18 & 5 & 3 & 1 & 4 & 31 & 9.33 & 6.74 & 16.06 & 21.46 & 29.32 & 38.37 \\
\hline & $4 / 12$ & 193 & 30 & 2 & 4 & 1 & 2 & 39 & 15.54 & 4.66 & 20.21 & 21.71 & 25.37 & 28.53 \\
\hline Mean & & & & & & & & & 12.04 & 4.92 & 16.96 & 21.86 & 23.46 & 29.86 \\
\hline \multirow[t]{3}{*}{ RM 64.5} & $4 / 10$ & 185 & 18 & 2 & 3 & 0 & 2 & 25 & 9.73 & 3.78 & 13.51 & 26.18 & 24.04 & 18.11 \\
\hline & $4 / 11$ & 192 & 10 & 2 & 2 & 0 & 5 & 19 & 5.21 & 4.69 & 9.90 & 30.43 & 23.96 & 41.35 \\
\hline & $4 / 12$ & 192 & 20 & 3 & 3 & 0 & 4 & 30 & 10.42 & 5.21 & 15.63 & 33.89 & 16.46 & 30.80 \\
\hline Mean & & & & & & & & & 8.45 & 4.56 & 13.01 & 29.91 & 19.44 & 30.80 \\
\hline $\mathrm{RM} 79^{a}$ & $4 / 10$ & 186 & 22 & 4 & 1 & 0 & 0 & 27 & 11.83 & 2.69 & 14.52 & 32.67 & 30.03 & 34.68 \\
\hline & $4 / 11$ & 191 & 20 & 5 & 2 & 2 & 1 & 30 & 10.47 & 5.24 & 15.71 & 34.00 & 26.17 & 46.60 \\
\hline & $4 / 12$ & 192 & 19 & 6 & 4 & 0 & 2 & 31 & 9.90 & 6.25 & 16.15 & 34.19 & 22.57 & 42.42 \\
\hline Mean & & & & & & & & & 10.73 & 4.73 & 15.46 & 34.06 & 27.47 & 42.83 \\
\hline
\end{tabular}


Appendix Table A-3. Maximum, minimum, and mean fork lengths $(\mathrm{mm})$ of natural and hatchery juvenile salmonids, lower Umatilla River, November 1999 - September 2000.

\begin{tabular}{llllllllllll}
\hline & \multicolumn{10}{c}{ Month } \\
\cline { 2 - 10 } Species $^{a}$ & Nov & Dec & Jan & Feb & Mar & Apr & May & Jun & Jul & Aug & Sep \\
\hline
\end{tabular}

Hatchery

\begin{tabular}{|c|c|c|c|c|c|c|c|c|c|c|c|c|}
\hline \multirow[t]{5}{*}{ CHS } & $\mathrm{N}$ & 0 & 0 & 0 & 0 & 127 & 909 & 192 & 1 & 2 & 0 & 0 \\
\hline & MAX & & & & & 185 & 195 & 210 & 130 & 245 & & \\
\hline & MIN & & & & & 110 & 114 & 120 & 130 & 216 & & \\
\hline & MEAN & & & & & 144 & 144 & 145 & 130 & 231 & & \\
\hline & $(\mathrm{SE})$ & & & & & 1.36 & 0.46 & 0.96 & - & 14.50 & & \\
\hline \multirow[t]{5}{*}{$\mathrm{CHF}$} & $\mathrm{N}$ & 0 & 0 & 0 & 0 & 46 & 1049 & 153 & 2 & 0 & 0 & 0 \\
\hline & MAX & & & & & 173 & 201 & 185 & 199 & & & \\
\hline & MIN & & & & & 113 & 109 & 115 & 150 & & & \\
\hline & MEAN & & & & & 155 & 154 & 147 & 175 & & & \\
\hline & $(\mathrm{SE})$ & & & & & 2.08 & 0.46 & 1.11 & 24.5 & & & \\
\hline \multirow[t]{5}{*}{$\mathrm{CH}$} & $\mathrm{N}$ & 0 & 0 & 0 & 0 & 383 & 296 & 36 & 0 & 0 & 0 & 5 \\
\hline & MAX & & & & & 186 & 194 & 182 & & & & 220 \\
\hline & MIN & & & & & 118 & 104 & 105 & & & & 182 \\
\hline & MEAN & & & & & 145 & 149 & 147 & & & & 200 \\
\hline & $(\mathrm{SE})$ & & & & & 0.61 & 0.88 & 2.78 & & & & 7.65 \\
\hline
\end{tabular}

\begin{tabular}{|c|c|c|c|c|c|c|c|c|c|c|c|}
\hline CHF0 & $\mathrm{N}$ & 0 & 0 & 0 & 0 & 0 & 0 & 490 & 884 & 12 & 0 \\
\hline & MAX & & & & & & & 129 & 131 & 136 & \\
\hline & MIN & & & & & & & 70 & 62 & 81 & \\
\hline & MEAN & & & & & & & 94 & 96 & 101 & \\
\hline & $(\mathrm{SE})$ & & & & & & & 0.37 & 0.32 & 4.33 & \\
\hline
\end{tabular}

\begin{tabular}{|c|c|c|c|c|c|c|c|c|c|c|c|}
\hline $\mathrm{COH}$ & $\mathrm{N}$ & 0 & 0 & 0 & 0 & 27 & 41 & 45 & 6 & 0 & 0 \\
\hline & MAX & & & & & 161 & 159 & 221 & 166 & & \\
\hline & MIN & & & & & 116 & 122 & 126 & 92 & & \\
\hline & MEAN & & & & & 134 & 139 & 144 & 130 & & \\
\hline & $(\mathrm{SE})$ & & & & & 2.27 & 1.53 & 2.14 & 12.43 & & \\
\hline
\end{tabular}

\begin{tabular}{llllllllllll} 
STS N & 0 & 0 & 0 & 0 & 0 & 202 & 465 & 95 & 2 & 0 & 0 \\
MAX & & & & & & 267 & 281 & 274 & 219 & & \\
MIN & & & & & & 138 & 135 & 115 & 205 & & \\
MEAN & & & & & 214 & 214 & 213 & 212 & & \\
(SE) & & & & & 1.36 & 1.29 & 2.54 & 7.00 & & \\
\hline
\end{tabular}

a $C H S=$ spring chinook salmon, $C H F=$ fall chinook salmon, $C H=$ chinook salmon, $C H F 0=$ subyearling fall chinook salmon, $\mathrm{COH}=$ coho salmon, and STS = summer steelhead. 
Appendix Table A-3. Continued.

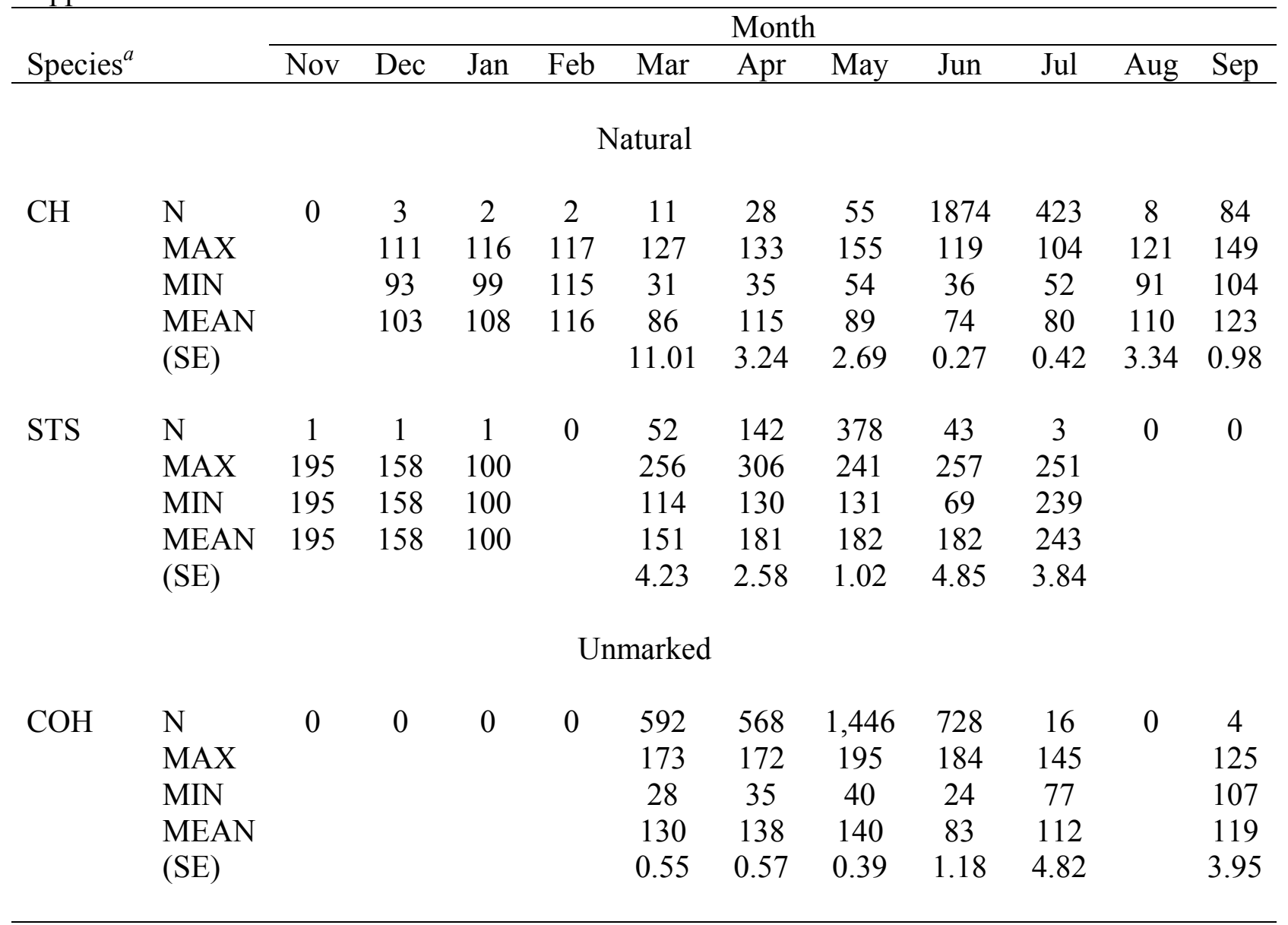


Appendix Table A-4. Pacific lamprey captures, trap efficiency estimates, and abundance estimates at the rotary-screw trap (RM 1.2) and West Extension Canal (RM 3.7), lower Umatilla River, October 1994 - June 2000.

\begin{tabular}{|c|c|c|c|c|c|c|}
\hline \multirow[b]{2}{*}{ Year } & \multicolumn{4}{|c|}{ Number captured } & \multirow{2}{*}{$\begin{array}{c}\text { Trap efficiency } \\
\text { of smolts }\end{array}$} & \multirow{2}{*}{$\begin{array}{c}\text { Abundance estimate } \\
\text { of smolts (C.I.) }\end{array}$} \\
\hline & Adult & Smolt $^{a}$ & Larvae & Unknown & & \\
\hline \multicolumn{7}{|c|}{ Rotary-screw Trap } \\
\hline $1995^{b}$ & -- & -- & -- & $6^{c}$ & -- & -- \\
\hline 1996 & -- & -- & -- & 29 & -- & -- \\
\hline 1997 & 7 & -- & -- & 297 & -- & -- \\
\hline 1998 & -- & 87 & 177 & -- & -- & -- \\
\hline 1999 & -- & 76 & 144 & -- & -- & -- \\
\hline 2000 & -- & 133 & 363 & -- & 0.008 & $17,157( \pm 14,902)$ \\
\hline \multicolumn{7}{|c|}{ West Extension Canal } \\
\hline $1995^{a}$ & 17 & -- & -- & 18 & -- & -- \\
\hline 1996 & 12 & -- & -- & 185 & -- & -- \\
\hline 1998 & 1 & 16 & 288 & -- & -- & -- \\
\hline 1999 & -- & -- & 53 & 1 & -- & -- \\
\hline 2000 & 1 & -- & -- & -- & -- & -- \\
\hline
\end{tabular}

a "Smolted" lamprey are macrophthalmia.

$b$ Implementation of Phase I water exchange in the lower Umatilla River.

c Three of these juvenile lamprey were captured in a Fyke net trap (RM 0.8). 
Appendix Table A-5. Daily observations at the rotary-screw trap (RM 1.2), lower Umatilla River, 1 October 1999 - 5 March 2000.

\begin{tabular}{|c|c|c|c|c|c|c|c|c|c|c|c|}
\hline \multirow[b]{2}{*}{ Date } & \multirow[b]{2}{*}{ Time } & \multirow[b]{2}{*}{ Debris $^{c}$} & \multicolumn{2}{|c|}{ Cone $\mathrm{RPM}^{b}$} & \multirow{2}{*}{$\begin{array}{c}\text { River } \\
\text { gauge }(\mathrm{ft} \text {. }\end{array}$} & \multicolumn{2}{|c|}{ Secchi depth } & \multicolumn{2}{|c|}{ Water temp. $\left({ }^{\circ} \mathrm{F}\right)$} & \multicolumn{2}{|c|}{ Air temp. $\left({ }^{\circ} \mathrm{F}\right)$} \\
\hline & & & Start & End & & Down & Up & Min. & Max. & Min. & Max. \\
\hline $10 / 1$ & 1350 & -- & 1.0 & 1.0 & 2.5 & -- & -- & 56 & 70 & -- & -- \\
\hline $10 / 5$ & 1430 & $\mathrm{H}$ & 0.0 & 1.3 & 2.6 & -- & -- & 54 & 62 & -- & -- \\
\hline $10 / 7$ & 1740 & $\mathrm{H}$ & 1.5 & 1.8 & 2.6 & -- & -- & 58 & 66 & -- & -- \\
\hline $10 / 9$ & 1400 & $\mathrm{H}$ & 2.0 & 2.0 & 2.6 & -- & -- & 58 & 60 & 46 & 70 \\
\hline $10 / 11$ & 1115 & M & 1.3 & 1.8 & 2.6 & $1.6^{* c}$ & 1.6 & 56 & 62 & 39 & 66 \\
\hline $10 / 13$ & 1330 & M & 0.0 & 1.0 & 2.7 & $1.6^{*}$ & 1.6 & 54 & 60 & 43 & 78 \\
\hline $10 / 15$ & 1330 & $\mathrm{H}$ & 1.3 & 2.0 & 2.7 & $1.7^{*}$ & 1.7 & 55 & 60 & 29 & 82 \\
\hline $10 / 17$ & 1245 & $\mathrm{H}$ & 1.8 & 2.3 & 2.7 & $1.7^{*}$ & 1.7 & 49 & 57 & 25 & 62 \\
\hline $10 / 19$ & 1645 & $\mathrm{H}$ & -- & 2.5 & 2.7 & $1.8^{*}$ & 1.8 & 50 & 52 & 28 & 66 \\
\hline $10 / 21$ & 800 & $\mathrm{H}$ & 0.0 & 2.0 & 2.7 & $1.7 *$ & 1.7 & 52 & 52 & 30 & 62 \\
\hline $10 / 23$ & 1100 & $\mathrm{H}$ & 1.5 & 2.8 & 2.7 & $1.7^{*}$ & 1.7 & 46 & 52 & 22 & 64 \\
\hline $10 / 25$ & 1220 & $\mathrm{H}$ & 2.5 & 2.0 & 2.7 & $1.8^{*}$ & 1.8 & 52 & 54 & 24 & 66 \\
\hline $10 / 27$ & 1400 & M & 0.0 & 1.3 & 2.8 & $1.6^{*}$ & 1.6 & 50 & 54 & 33 & 58 \\
\hline $10 / 29$ & 1315 & M & 2.0 & 2.3 & 2.8 & $1.6^{*}$ & 1.6 & 48 & 51 & 38 & 60 \\
\hline $10 / 31$ & 1215 & $M$ & 1.0 & 1.8 & 2.8 & $1.7^{*}$ & $1.7^{*}$ & 49 & 53 & 38 & 64 \\
\hline $11 / 2$ & 1330 & $\mathrm{H}$ & 2.0 & 2.0 & 2.8 & $1.7^{*}$ & 1.7 & 46 & 52 & 30 & 58 \\
\hline $11 / 4$ & 1330 & $\mathrm{H}$ & 0.0 & 2.3 & 2.8 & $1.8^{*}$ & 1.8 & 46 & 48 & 31 & 59 \\
\hline $11 / 7$ & 1000 & $\mathrm{H}$ & 0.0 & 2.0 & 2.8 & $1.7^{*}$ & 1.7 & 48 & 50 & 30 & 52 \\
\hline $11 / 8$ & 1400 & $\mathrm{M}$ & 2.3 & 2.8 & 2.8 & $1.7 *$ & 1.7 & 48 & 51 & 44 & 53 \\
\hline $11 / 10$ & 1315 & $\mathrm{M}$ & 2.8 & 2.5 & 2.8 & $1.6^{*}$ & 1.6 & 49 & 52 & 40 & 61 \\
\hline $11 / 12$ & 1430 & M & 0.0 & 2.5 & 2.8 & $1.6^{*}$ & 1.6 & 51 & 54 & 41 & 73 \\
\hline $11 / 15$ & 800 & $\mathrm{M}$ & 0.0 & 2.0 & 2.8 & 1.4 & 1.4 & 53 & 56 & 41 & 74 \\
\hline $11 / 18$ & 1315 & $\mathrm{H}$ & 0.0 & 2.0 & 2.8 & $1.7^{*}$ & 1.7 & 48 & 52 & 30 & 56 \\
\hline $11 / 20$ & 900 & $\mathrm{H}$ & 1.8 & 1.5 & 2.7 & $1.7^{*}$ & 1.7 & 46 & 50 & 42 & 52 \\
\hline $11 / 22$ & 1615 & $\mathrm{H}$ & 0.0 & 2.8 & 2.7 & $1.7^{*}$ & 1.7 & 46 & 50 & 32 & 54 \\
\hline $11 / 24$ & 1415 & $\mathrm{M}$ & 2.3 & 2.3 & 2.6 & $1.7^{*}$ & 1.7 & 45 & 46 & 45 & 50 \\
\hline $11 / 26$ & 1215 & $\mathrm{M}$ & 1.3 & 1.3 & 2.5 & $1.6^{*}$ & 1.6 & 46 & 53 & 45 & 60 \\
\hline $11 / 28$ & 1500 & $\mathrm{M}$ & 0.0 & 3.0 & 3.1 & 0.7 & 0.7 & 46 & 52 & 29 & 54 \\
\hline $11 / 29$ & 1420 & $\mathrm{~L}$ & 1.3 & 1.0 & 2.8 & 1.5 & 1.0 & 44 & 45 & 32 & 46 \\
\hline $11 / 30$ & 1400 & -- & 1.3 & 0.6 & 2.8 & 1.3 & 1.3 & 44 & 46 & 38 & 50 \\
\hline $12 / 1$ & 1315 & $\mathrm{~L}$ & 1.5 & 1.3 & 2.8 & 1.4 & 1.4 & 46 & 54 & 36 & 54 \\
\hline $12 / 2$ & 1615 & $\mathrm{M}$ & 0.0 & 1.0 & 2.8 & -- & -- & 46 & 48 & 42 & 53 \\
\hline $12 / 3$ & 800 & M & 0.5 & 4.3 & 3.5 & 0.0 & 0.0 & 44 & 46 & 28 & 44 \\
\hline
\end{tabular}


Appendix Table A-5. Continued.

\begin{tabular}{|c|c|c|c|c|c|c|c|c|c|c|c|}
\hline \multirow[b]{2}{*}{ Date } & \multirow[b]{2}{*}{ Time } & \multirow[b]{2}{*}{ Debris $^{a}$} & \multicolumn{2}{|c|}{ Cone $\mathrm{RPM}^{b}$} & \multirow{2}{*}{$\begin{array}{c}\text { River } \\
\text { gauge }(\mathrm{ft} .)\end{array}$} & \multicolumn{2}{|c|}{ Secchi depth } & \multicolumn{2}{|c|}{ Water temp. $\left({ }^{\circ} \mathrm{F}\right)$} & \multicolumn{2}{|c|}{ Air temp. $\left({ }^{\circ} \mathrm{F}\right)$} \\
\hline & & & Start & End & & Down & Up & Min. & Max. & Min. & Max. \\
\hline $12 / 4$ & 1100 & -- & 3.8 & 3.5 & 3.3 & 0.0 & 0.0 & 42 & 42 & 26 & 42 \\
\hline $12 / 5$ & 940 & M & 2.5 & 2.5 & 3.1 & 0.1 & 0.1 & 42 & 42 & 28 & 43 \\
\hline $12 / 7$ & 1045 & $\mathrm{~L}$ & 0.0 & 1.3 & 2.9 & 1.5 & 1.5 & 41 & 44 & 32 & 55 \\
\hline $12 / 9$ & 1530 & $\mathrm{~L}$ & 2.3 & 2.3 & 2.8 & $1.7^{*}$ & 1.7 & 42 & 44 & 26 & 49 \\
\hline $12 / 11$ & 1530 & $\mathrm{~L}$ & 2.0 & 2.0 & 2.8 & $1.7^{*}$ & 1.7 & 42 & 46 & 31 & 60 \\
\hline $12 / 14$ & 1500 & M & 0.0 & 3.0 & 3.2 & 1.1 & 1.1 & 43 & 48 & 35 & 55 \\
\hline $12 / 16$ & 1500 & $\mathrm{H}$ & 3.5 & 4.0 & 3.3 & 1.5 & 1.0 & 42 & 48 & 43 & 58 \\
\hline $12 / 17$ & 1350 & $\mathrm{~L}$ & 0.0 & 5.8 & 3.8 & 0.4 & 0.4 & 46 & 50 & 42 & 58 \\
\hline $12 / 18$ & 1130 & $\mathrm{H}$ & 0.0 & 6.3 & 3.9 & 0.4 & 0.3 & 46 & 48 & 42 & 52 \\
\hline $12 / 19$ & 1130 & $\mathrm{~L}$ & 0.0 & 7.5 & 4.0 & 0.3 & 0.3 & 44 & 44 & 34 & 52 \\
\hline $12 / 20$ & 1530 & M & 5.8 & 5.8 & -- & 0.5 & 0.5 & 43 & 44 & 28 & 52 \\
\hline $12 / 21$ & 1500 & M & 5.0 & 4.8 & 3.4 & 0.8 & 0.8 & 42 & 45 & 27 & 36 \\
\hline $12 / 22$ & 1515 & $\mathrm{~L}$ & 3.5 & 3.8 & 3.2 & 1.0 & 0.9 & 41 & 41 & 29 & 35 \\
\hline $12 / 23$ & 1500 & L & 2.5 & 2.0 & 3.0 & 1.1 & 1.1 & 40 & 41 & 33 & 35 \\
\hline $12 / 26$ & 1400 & L & 1.3 & 0.8 & 2.9 & $1.6^{*}$ & 1.6 & 38 & 42 & 32 & 36 \\
\hline $12 / 28$ & 800 & L & 1.8 & 2.5 & 2.8 & $1.6^{*}$ & 1.6 & 40 & 40 & 24 & 34 \\
\hline $12 / 31$ & 1310 & M & 0.0 & 2.0 & 2.8 & $1.7^{*}$ & 1.7 & 40 & 42 & 31 & 36 \\
\hline $1 / 3$ & 1530 & L & 3.0 & 3.3 & 2.8 & $1.7^{*}$ & 1.7 & 38 & 40 & 27 & 48 \\
\hline $1 / 6$ & 1330 & $\mathrm{M}$ & 3.0 & 2.8 & 3.0 & 0.7 & 0.6 & 40 & 42 & 25 & 49 \\
\hline $1 / 8$ & 1115 & $\mathrm{M}$ & 2.8 & 2.8 & 2.8 & 0.4 & 0.4 & 39 & 43 & 27 & 49 \\
\hline $1 / 10$ & 1330 & $\mathrm{M}$ & 0.0 & 2.8 & 2.9 & 1.1 & 1.0 & 42 & 44 & 37 & 55 \\
\hline $1 / 12$ & 1330 & M & 3.0 & 3.3 & 2.8 & 1.2 & 1.2 & 40 & 42 & 29 & 43 \\
\hline $1 / 14$ & 1415 & L & 3.3 & 3.3 & 2.8 & 1.5 & 1.4 & 41 & 43 & 35 & 45 \\
\hline $1 / 18$ & 1620 & $\mathrm{H}$ & 5.8 & 5.8 & 3.5 & 0.7 & 0.6 & 40 & 46 & 26 & 48 \\
\hline $1 / 20$ & 940 & M & 3.5 & 3.3 & 3.0 & 0.5 & 0.4 & 40 & 40 & 24 & 34 \\
\hline $1 / 22$ & 1430 & $\mathrm{~L}$ & 2.8 & 2.0 & 2.8 & 1.4 & 1.4 & 40 & 42 & 32 & 36 \\
\hline $1 / 24$ & 1430 & L & 3.3 & 3.8 & 2.8 & $1.7^{*}$ & 1.7 & 39 & 41 & 31 & 36 \\
\hline $1 / 26$ & 1415 & $\mathrm{M}$ & 3.3 & 3.3 & 2.8 & 1.6 & 1.5 & 42 & 43 & 27 & 47 \\
\hline $1 / 28$ & 1500 & $\mathrm{M}$ & 2.8 & 3.0 & 2.8 & 1.4 & 1.3 & 38 & 44 & 24 & 46 \\
\hline $1 / 30$ & 1300 & $\mathrm{~L}$ & 3.8 & 3.5 & 2.8 & 1.6 & 1.6 & 37 & 41 & 26 & 33 \\
\hline $2 / 1$ & 1345 & $\mathrm{~L}$ & 3.5 & 3.5 & 2.8 & 1.6 & 1.5 & 36 & 42 & 26 & 42 \\
\hline $2 / 3$ & 1615 & $\mathrm{M}$ & 3.3 & -- & 2.8 & 0.9 & 0.9 & 41 & 46 & 34 & 51 \\
\hline $2 / 5$ & 1300 & M & 3.5 & -- & 3.0 & 0.6 & 0.5 & 41 & 46 & 29 & 43 \\
\hline $2 / 7$ & 1530 & M & 0.0 & 3.3 & 2.9 & 0.7 & 0.7 & 42 & 46 & 33 & 49 \\
\hline $2 / 9$ & 1000 & $\mathrm{H}$ & 0.0 & 5.8 & 3.4 & 0.4 & 0.4 & 42 & 46 & 30 & 46 \\
\hline $2 / 11$ & 1530 & $\mathrm{~L}$ & 0.0 & 6.0 & 3.4 & 0.6 & 0.6 & 42 & 46 & 25 & 51 \\
\hline $2 / 14$ & 800 & $\mathrm{H}$ & -- & 4.0 & 3.3 & 0.9 & 0.9 & 38 & 42 & 28 & 46 \\
\hline $2 / 15$ & 800 & $\mathrm{H}$ & 0.0 & 9.5 & 4.1 & 0.0 & 0.0 & 38 & 42 & 36 & 40 \\
\hline
\end{tabular}


Appendix Table A-5. Continued.

Cone $\mathrm{RPM}^{b}$ River Secchi depth Water temp. $\left({ }^{\circ} \mathrm{F}\right)$ Air temp. $\left({ }^{\circ} \mathrm{F}\right)$

Date Time Debris ${ }^{a}$ Start End gauge (ft.) Down Up Min. Max. Min. Max.

\begin{tabular}{cccccccccccc}
\hline $2 / 16$ & 1030 & M & 0.0 & 8.5 & 4.2 & -- & -- & 42 & 42 & 30 & 52 \\
$2 / 17$ & 925 & H & -- & 8.8 & 3.8 & 0.3 & 0.3 & 40 & 42 & 26 & 51 \\
$2 / 18$ & 800 & - & -- & 6.5 & 3.6 & 0.5 & 0.4 & 40 & 44 & 24 & 50 \\
$2 / 20$ & 1545 & M & -- & 5.0 & 3.3 & 0.6 & 0.6 & 40 & 42 & 24 & 56 \\
$2 / 22$ & 800 & M & -- & 4.0 & 3.1 & 0.7 & 0.7 & 40 & 44 & 32 & 48 \\
$2 / 24$ & 945 & H & 0.0 & 6.5 & 3.4 & 0.4 & 0.4 & 44 & 46 & 29 & 62 \\
$2 / 26$ & 1400 & H & -- & 4.8 & 3.4 & 0.7 & 0.6 & 42 & 45 & 24 & 63 \\
$2 / 28$ & 2000 & M & 0.0 & 8.8 & 4.2 & 0.2 & 0.1 & 44 & 46 & 24 & 56 \\
$2 / 29$ & 1445 & H & -- & 8.8 & 4.2 & 0.2 & 0.2 & 46 & 46 & 39 & 56 \\
$3 / 1$ & & M & -- & 8.5 & 4.1 & -- & -- & 42 & 46 & 31 & 56 \\
$3 / 2$ & 800 & H & -- & 9.0 & 3.8 & 0.4 & 0.3 & 44 & 48 & 30 & 56 \\
$3 / 5$ & 1530 & L & -- & -- & -- & -- & -- & 46 & 48 & 32 & 54 \\
\hline
\end{tabular}


Appendix Table A-6. Daily observations at the West Extension Canal sampling facility (RM 3.7), 7 March - 29 September 2000.

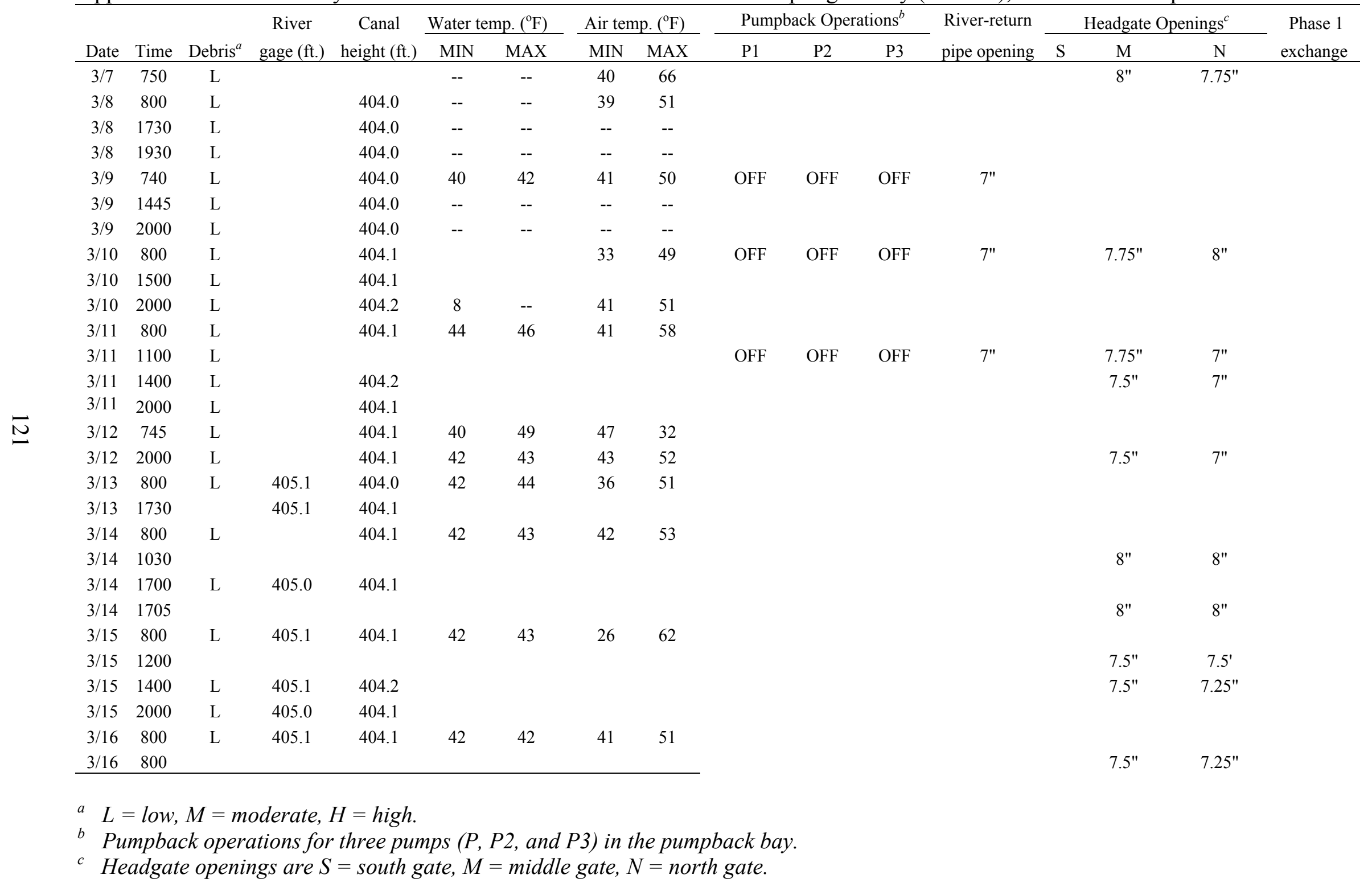


Appendix Table A-6. Continued.

\begin{tabular}{|c|c|c|c|c|c|c|c|c|c|c|c|c|c|c|c|c|}
\hline \multirow[b]{2}{*}{ Date } & \multirow[b]{2}{*}{ Time } & \multirow[b]{2}{*}{ Debris $^{a}$} & \multirow{2}{*}{$\begin{array}{c}\text { River } \\
\text { gage (ft.) }\end{array}$} & \multirow{2}{*}{$\begin{array}{c}\text { Canal } \\
\text { height (ft.) }\end{array}$} & \multicolumn{2}{|c|}{ Water temp. $\left({ }^{\circ} \mathrm{F}\right)$} & \multicolumn{2}{|c|}{ Air temp. $\left({ }^{\circ} \mathrm{F}\right)$} & \multicolumn{3}{|c|}{ Pumpback Operations ${ }^{b}$} & \multirow{2}{*}{$\begin{array}{l}\text { River-return } \\
\text { pipe opening }\end{array}$} & \multicolumn{3}{|c|}{ Headgate Openings $^{c}$} & \multirow{2}{*}{$\begin{array}{c}\text { Phase } 1 \\
\text { exchange }\end{array}$} \\
\hline & & & & & MIN & MAX & MIN & MAX & $\mathrm{P} 1$ & $\mathrm{P} 2$ & P3 & & $\mathrm{S}$ & M & $\mathrm{N}$ & \\
\hline $3 / 16$ & 1200 & & & & & & & & & & & & & $7.5^{\prime \prime}$ & $7.25^{\prime \prime}$ & \\
\hline $3 / 16$ & 1500 & $\mathrm{~L}$ & 405.1 & 404.0 & & & & & & & & & & & & \\
\hline $3 / 16$ & 2000 & $\mathrm{~L}$ & 405.1 & 404.1 & & & & & & & & & & & & \\
\hline $3 / 17$ & 800 & $\mathrm{~L}$ & & 404.2 & 41 & 42 & 41 & 53 & & & & & & & & \\
\hline $3 / 17$ & 1200 & & & & & & & & & & & & & 7" & $7.25^{\prime \prime}$ & \\
\hline $3 / 17$ & 1800 & $\mathrm{~L}$ & 405.2 & 404.2 & & & & & & & & & & & & \\
\hline $3 / 17$ & 2000 & $\mathrm{~L}$ & 405.1 & 404.1 & & & & & & & & & & & & \\
\hline $3 / 18$ & 1500 & $\mathrm{~L}$ & 405.1 & 404.1 & 42 & 44 & 35 & 56 & & & & & & & & \\
\hline $3 / 18$ & 2000 & $\mathrm{~L}$ & 405.2 & 404.1 & & & & & & & & & & & & \\
\hline $3 / 19$ & 800 & $\mathrm{~L}$ & 405.1 & 404.1 & 42 & 42 & 39 & 50 & & & & & & & & \\
\hline $3 / 19$ & 1830 & $\mathrm{~L}$ & 405.1 & 404.1 & & & & & & & & & & & & \\
\hline $3 / 20$ & 800 & $\mathrm{~L}$ & 405.2 & 404.2 & 39 & 41 & 29 & 49 & & & & & & & & \\
\hline $3 / 20$ & 1200 & & & & & & & & OFF & OFF & OFF & 7" & & 7" & $7.25^{\prime \prime}$ & \\
\hline $3 / 21$ & 800 & $\mathrm{~L}$ & 405.1 & 404.1 & 39 & 41 & 41 & 52 & & & & & & & & \\
\hline $3 / 21$ & 1200 & & & & & & & & OFF & OFF & OFF & 7" & & & & \\
\hline $3 / 21$ & 1400 & $\mathrm{~L}$ & 405.2 & 404.1 & & & & & & & & & & & & \\
\hline $3 / 21$ & 1400 & $\mathrm{~L}$ & 405.1 & 404.1 & & & & & & & & & & & & \\
\hline $3 / 22$ & $800^{d}$ & $\mathrm{~L}$ & 405.0 & 404.0 & 43 & 46 & 38 & 64 & & & & & & & & \\
\hline $3 / 22$ & 1200 & & & & & & & & OFF & OFF & OFF & 7" & 13" & 7.75" & 7.75" & \\
\hline $3 / 22$ & 1400 & $\mathrm{~L}$ & 405.0 & 404.2 & & & & & & & & & & & & \\
\hline $3 / 23$ & 800 & M & 405.0 & 404.2 & 45 & 48 & 40 & 64 & & & & & & & & \\
\hline $3 / 23$ & 1100 & & & & & & & & OFF & OFF & OFF & 7" & 16.25" & $14.75^{\prime \prime}$ & $14.75^{\prime \prime}$ & \\
\hline $3 / 23$ & 1600 & $\mathrm{~L}$ & -- & 404.4 & & & & & & & & & 13" & 13" & $12.75^{\prime \prime}$ & \\
\hline $3 / 23$ & 2000 & $\mathrm{~L}$ & 405.0 & 404.2 & & & & & & & & & $12.25^{\prime \prime}$ & $11 "$ & $11.25^{\prime \prime}$ & \\
\hline $3 / 24$ & 900 & $\mathrm{H}$ & 405.4 & 404.3 & 44 & 47 & 32 & 56 & & & & & & & & \\
\hline $3 / 24$ & 1200 & & & & & & & & OFF & OFF & OFF & 7" & $10 "$ & $8 "$ & $7.75^{\prime \prime}$ & \\
\hline $3 / 24$ & 1330 & & & & & & & & & & & & $10^{\prime \prime}$ & $8.5^{\prime \prime}$ & $8.5^{\prime \prime}$ & \\
\hline $3 / 24$ & 2130 & M & -- & 404.1 & & & & & & & & & & & & \\
\hline $3 / 25$ & 800 & M & 405.4 & 404.0 & 43 & 45 & 37 & 60 & & & & & & & & \\
\hline $3 / 25$ & 1200 & & & & & & & & OFF & OFF & OFF & 7" & 9.88" & 9" & 9" & \\
\hline $3 / 25$ & 1400 & $\mathrm{H}$ & 404.4 & 404.1 & & & & & & & & & & & & \\
\hline
\end{tabular}


Appendix Table A-6. Continued.

\begin{tabular}{|c|c|c|c|c|c|c|c|c|c|c|c|c|c|c|c|c|}
\hline \multirow[b]{2}{*}{ Date } & \multirow[b]{2}{*}{ Time } & \multirow[b]{2}{*}{ Debris $^{a}$} & \multirow{2}{*}{$\begin{array}{c}\text { River } \\
\text { gage (ft.) }\end{array}$} & \multirow{2}{*}{$\begin{array}{c}\text { Canal } \\
\text { height (ft.) }\end{array}$} & \multicolumn{2}{|c|}{ Water temp. $\left({ }^{\circ} \mathrm{F}\right)$} & \multicolumn{2}{|c|}{ Air temp. $\left({ }^{\circ} \mathrm{F}\right)$} & \multicolumn{3}{|c|}{ Pumpback Operations $^{b}$} & \multirow{2}{*}{$\begin{array}{l}\text { River-return } \\
\text { pipe opening }\end{array}$} & \multicolumn{3}{|c|}{ Headgate Openings ${ }^{c}$} & \multirow{2}{*}{$\begin{array}{c}\text { Phase } 1 \\
\text { exchange }\end{array}$} \\
\hline & & & & & MIN & MAX & MIN & MAX & $\mathrm{P} 1$ & $\mathrm{P} 2$ & $\mathrm{P} 3$ & & $\mathrm{~S}$ & $\mathrm{M}$ & $\mathrm{N}$ & \\
\hline $3 / 25$ & 1400 & $\mathrm{~L}$ & 405.4 & 404.1 & & & & & & & & & & & & \\
\hline $3 / 26$ & 800 & $\mathrm{~L}$ & 405.3 & 404.0 & 42 & 43 & 43 & 61 & & & & & & & & \\
\hline $3 / 27$ & 800 & $\mathrm{~L}$ & 405.2 & 404.0 & 42 & 43 & 41 & 60 & & & & & & & & \\
\hline $3 / 27$ & 1200 & & & & & & & & OFF & OFF & OFF & 7" & $9.75^{\prime \prime}$ & $10^{\prime \prime}$ & $10 "$ & \\
\hline $3 / 27$ & 1400 & $\mathrm{~L}$ & 405.2 & 404.0 & & & & & & & & & & & & \\
\hline $3 / 28$ & 830 & $\mathrm{~L}$ & 405.2 & 404.1 & 45 & 48 & 41 & 60 & & & & & & & & \\
\hline $3 / 28$ & 1300 & & & & & & & & OFF & OFF & OFF & $7 "$ & $12.25^{\prime \prime}$ & $11.5^{\prime \prime}$ & $11.5^{\prime \prime}$ & \\
\hline $3 / 28$ & 1500 & M & 405.2 & 404.1 & & & & & & & & & & & & \\
\hline $3 / 29$ & 800 & M & 405.3 & 404.2 & 46 & 46 & 38 & 58 & & & & & & & & \\
\hline $3 / 29$ & 1230 & & & & & & & & OFF & OFF & OFF & 7" & $12^{\prime \prime}$ & $11 "$ & $12.25^{\prime \prime}$ & \\
\hline $3 / 29$ & 1400 & M & 405.3 & 404.1 & & & & & & & & & & & & \\
\hline $3 / 29$ & 1800 & M & 405.2 & 404.1 & & & & & & & & & & & & \\
\hline $3 / 29$ & 1800 & M & 405.3 & 404.1 & & & & & & & & & & & & \\
\hline $3 / 30$ & 830 & $\mathrm{~L}$ & 405.2 & 404.0 & 44 & 44 & 32 & 56 & & & & & & & & \\
\hline $3 / 30$ & 1200 & & & & & & & & OFF & OFF & OFF & 7" & $12 "$ & 11.5" & $11.75^{\prime \prime}$ & \\
\hline $3 / 30$ & 1400 & $\mathrm{~L}$ & 405.2 & 404.1 & & & & & & & & & & & & \\
\hline $3 / 30$ & 1800 & $\mathrm{~L}$ & 405.2 & 404.1 & & & & & & & & & & & & \\
\hline $3 / 31$ & 630 & $\mathrm{~L}$ & 405.1 & 404.0 & 42 & 42 & 29 & 60 & & & & & & & & \\
\hline $4 / 1$ & 830 & $\mathrm{~L}$ & 405.0 & 404.2 & 44 & 47 & 38 & 68 & & & & & & & & \\
\hline $4 / 1$ & 1200 & $\mathrm{~L}$ & & & & & & & OFF & OFF & OFF & 7" & 13" & $12.75^{\prime \prime}$ & $13^{\prime \prime}$ & \\
\hline $4 / 1$ & 1400 & $\mathrm{~L}$ & 405.0 & 404.2 & & & & & & & & & & & & \\
\hline $4 / 2$ & 830 & $\mathrm{~L}$ & 405.0 & 404.2 & -- & -- & -- & -- & & & & & & & & \\
\hline $4 / 2$ & 1200 & & & & & & & & OFF & OFF & OFF & 7" & $16.25^{\prime \prime}$ & $14.75^{\prime \prime}$ & $14.75^{\prime \prime}$ & \\
\hline $4 / 2$ & 1400 & $\mathrm{~L}$ & 405.0 & 404.1 & & & & & & & & & & & & \\
\hline $4 / 2$ & 1800 & $\mathrm{~L}$ & 405.0 & 404.1 & & & & & & & & & & & & \\
\hline $4 / 3$ & 845 & $\mathrm{~L}$ & 405.1 & 404.2 & 47 & 52 & 42 & 74 & & & & & & & & \\
\hline $4 / 3$ & 1300 & & & & & & & & OFF & OFF & OFF & 7" & $16.25^{\prime \prime}$ & $14.75^{\prime \prime}$ & $14.75^{\prime \prime}$ & \\
\hline $4 / 3$ & 1400 & $\mathrm{~L}$ & 405.2 & 404.2 & & & & & & & & & & & & \\
\hline $4 / 3$ & 1700 & $\mathrm{~L}$ & 405.0 & 404.1 & & & & & & & & & & & & \\
\hline $4 / 4$ & 1000 & $\mathrm{~L}$ & 405.3 & 404.1 & 48 & 50 & 51 & 71 & & & & & & & & \\
\hline $4 / 4$ & 1200 & & & & & & & & OFF & OFF & OFF & 7" & -- & -- & -- & \\
\hline
\end{tabular}


Appendix Table A-6. Continued.

\begin{tabular}{|c|c|c|c|c|c|c|c|c|c|c|c|c|c|c|c|c|}
\hline \multirow[b]{2}{*}{ Date } & \multirow[b]{2}{*}{ Time } & \multirow[b]{2}{*}{ Debris $^{a}$} & \multirow{2}{*}{$\begin{array}{c}\text { River } \\
\text { gage (ft.) }\end{array}$} & \multirow{2}{*}{$\begin{array}{c}\text { Canal } \\
\text { height (ft.) }\end{array}$} & \multicolumn{2}{|c|}{ Water temp. $\left({ }^{\circ} \mathrm{F}\right)$} & \multicolumn{2}{|c|}{ Air temp. $\left({ }^{\circ} \mathrm{F}\right)$} & \multicolumn{3}{|c|}{ Pumpback Operations $^{b}$} & \multirow{2}{*}{$\begin{array}{l}\text { River-return } \\
\text { pipe opening }\end{array}$} & \multicolumn{3}{|c|}{ Headgate Openings ${ }^{c}$} & \multirow{2}{*}{$\begin{array}{l}\text { Phase } 1 \\
\text { exchange }\end{array}$} \\
\hline & & & & & MIN & MAX & MIN & MAX & $\mathrm{P} 1$ & $\mathrm{P} 2$ & $\mathrm{P} 3$ & & $\mathrm{~S}$ & $\mathrm{M}$ & $\mathrm{N}$ & \\
\hline $4 / 4$ & 1700 & $\mathrm{~L}$ & 405.3 & 404.2 & & & & & & & & & & & & \\
\hline $4 / 5$ & 830 & $\mathrm{~L}$ & 405.4 & 404.1 & 43 & 51 & 41 & 64 & & & & & & & & \\
\hline $4 / 5$ & 1200 & & & & & & & & OFF & OFF & OFF & 7" & -- & -- & -- & \\
\hline $4 / 5$ & 1518 & M & 405.5 & 404.2 & & & & & & & & & & & & \\
\hline $4 / 6$ & 800 & $\mathrm{~L}$ & 405.4 & 404.2 & 42 & 43 & 41 & 52 & & & & & & & & \\
\hline $4 / 6$ & 1200 & & & & & & & & OFF & OFF & OFF & 7" & -- & -- & -- & \\
\hline $4 / 7$ & 800 & $\mathrm{~L}$ & 405.2 & 404.1 & 42 & 43 & 42 & 60 & & & & & & & & \\
\hline $4 / 7$ & 1200 & & & & & & & & OFF & OFF & OFF & -- & -- & -- & -- & \\
\hline $4 / 7$ & 1700 & M & 405.4 & 404.1 & & & & & & & & & & & & \\
\hline $4 / 8$ & 850 & $\mathrm{~L}$ & 405.0 & 404.0 & 47 & 49 & 32 & 61 & & & & & & & & \\
\hline $4 / 8$ & 1200 & & & & & & & & OFF & OFF & OFF & 7" & -- & -- & -- & \\
\hline $4 / 8$ & 1600 & $\mathrm{~L}$ & 405.1 & 404.1 & & & & & & & & & & & & \\
\hline $4 / 9$ & 800 & $\mathrm{~L}$ & 405.0 & 404.1 & 47 & 50 & 41 & 63 & & & & & & & & \\
\hline $4 / 9$ & 1600 & $\mathrm{~L}$ & 405.0 & 404.0 & & & & & & & & & & & & \\
\hline $4 / 10$ & 830 & $\mathrm{~L}$ & 405.0 & 404.1 & 50 & 51 & 42 & 70 & & & & & & & & \\
\hline $4 / 10$ & 1200 & & & & & & & & OFF & OFF & OFF & 7" & -- & -- & -- & \\
\hline $4 / 11$ & 800 & $\mathrm{~L}$ & 405.1 & 404.1 & 50 & 53 & 40 & 69 & & & & & & & & \\
\hline $4 / 11$ & 1200 & & & & & & & & OFF & OFF & OFF & 7" & -- & -- & -- & \\
\hline $4 / 12$ & 800 & $\mathrm{~L}$ & 405.1 & 404.2 & 50 & 53 & 48 & 74 & & & & & & & & \\
\hline $4 / 12$ & 1045 & & & & & & & & -- & -- & -- & -- & $17.5^{\prime \prime}$ & $17 "$ & $17.5^{\prime \prime}$ & \\
\hline $4 / 12$ & 1200 & & & & & & & & -- & -- & -- & -- & -- & -- & -- & \\
\hline $4 / 13$ & 830 & $\mathrm{~L}$ & 405.1 & 404.1 & 52 & 56 & 55 & 78 & & & & & & & & \\
\hline $4 / 13$ & 1200 & & & & & & & & OFF & OFF & OFF & 7" & $20.5^{\prime \prime}$ & 19" & $18.75^{\prime \prime}$ & \\
\hline $4 / 13$ & 1430 & $\mathrm{~L}$ & 405.1 & 404.2 & & & & & & & & & & & & \\
\hline $4 / 13$ & 1630 & $\mathrm{~L}$ & 405.1 & 404.1 & & & & & & & & & & & & \\
\hline $4 / 14$ & 850 & $\mathrm{~L}$ & 405.3 & 404.2 & 50 & 51 & 50 & 62 & & & & & & & & \\
\hline $4 / 14$ & 1200 & & & & & & & & OFF & OFF & OFF & 7" & -- & -- & -- & \\
\hline $4 / 14$ & 1800 & $\mathrm{~L}$ & 405.1 & 404.1 & & & & & & & & & & & & \\
\hline $4 / 15$ & 800 & $\mathrm{~L}$ & 405.2 & 404.2 & 49 & 50 & 52 & 65 & & & & & & & & \\
\hline $4 / 15$ & 1200 & & & & & & & & OFF & OFF & OFF & 7" & 19 & 18 & 18 & \\
\hline $4 / 15$ & 1520 & M & 405.4 & 404.3 & & & & & & & & & & & & \\
\hline $4 / 16$ & 830 & $\mathrm{~L}$ & 405.1 & 404.1 & 49 & 50 & 49 & 62 & & & & & & & & \\
\hline
\end{tabular}


Appendix Table A-6. Continued.

\begin{tabular}{|c|c|c|c|c|c|c|c|c|c|c|c|c|c|c|c|c|}
\hline \multirow[b]{2}{*}{ Date } & \multirow[b]{2}{*}{ Time } & \multirow[b]{2}{*}{ Debris $^{a}$} & \multirow{2}{*}{$\begin{array}{c}\text { River } \\
\text { gage (ft.) }\end{array}$} & \multirow{2}{*}{$\begin{array}{c}\text { Canal } \\
\text { height (ft.) }\end{array}$} & \multicolumn{2}{|c|}{ Water temp. $\left({ }^{\circ} \mathrm{F}\right)$} & \multicolumn{2}{|c|}{ Air temp. $\left({ }^{\circ} \mathrm{F}\right)$} & \multicolumn{3}{|c|}{ Pumpback Operations $^{b}$} & \multirow{2}{*}{$\begin{array}{l}\text { River-return } \\
\text { pipe opening }\end{array}$} & \multicolumn{3}{|c|}{ Headgate Openings $^{c}$} & \multirow{2}{*}{$\begin{array}{c}\text { Phase } 1 \\
\text { exchange }\end{array}$} \\
\hline & & & & & MIN & MAX & MIN & MAX & $\mathrm{P} 1$ & $\mathrm{P} 2$ & $\mathrm{P} 3$ & & $\mathrm{~S}$ & $\mathrm{M}$ & $\mathrm{N}$ & \\
\hline $4 / 16$ & 1200 & & & & & & & & OFF & OFF & OFF & 7" & $19 "$ & $18^{\prime \prime}$ & $18^{\prime \prime}$ & \\
\hline $4 / 17$ & 830 & $\mathrm{~L}$ & 405.0 & 404.1 & 49 & 50 & 46 & 64 & & & & & & & & \\
\hline $4 / 17$ & 1200 & & & & & & & & OFF & OFF & OFF & 7" & $19 "$ & $18^{\prime \prime}$ & $18^{\prime \prime}$ & \\
\hline $4 / 17$ & 1400 & $\mathrm{~L}$ & 405.1 & 404.1 & & & & & & & & & & & & \\
\hline $4 / 18$ & 835 & $\mathrm{~L}$ & 404.8 & 404.1 & 50 & 52 & 51 & 64 & & & & & & & & \\
\hline $4 / 18$ & 1200 & $\mathrm{~L}$ & & & & & & & OFF & OFF & OFF & 7" & $20 "$ & $19^{\prime \prime}$ & 18.75" & \\
\hline $4 / 19$ & 800 & $\mathrm{~L}$ & 404.8 & 404.0 & 52 & 53 & 44 & 71 & & & & & & & & \\
\hline $4 / 19$ & 1200 & $\mathrm{~L}$ & & & & & & & OFF & OFF & OFF & 7" & $20 "$ & $19^{\prime \prime}$ & 18.75" & \\
\hline $4 / 19$ & 1605 & $\mathrm{~L}$ & 404.8 & 404.1 & & & & & & & & & & & & \\
\hline $4 / 19$ & 1800 & $\mathrm{~L}$ & 404.9 & 404.0 & & & & & & & & & & & & \\
\hline $4 / 20$ & 820 & $\mathrm{~L}$ & 404.8 & 404.1 & 51 & 54 & 52 & 69 & & & & & & & & \\
\hline $4 / 20$ & 1200 & & & & & & & & OFF & OFF & OFF & 7" & $18^{\prime \prime}$ & $19^{\prime \prime}$ & 18.75" & \\
\hline $4 / 21$ & 839 & $\mathrm{~L}$ & 404.7 & 404.1 & 52 & 54 & 48 & 70 & & & & & & & & \\
\hline $4 / 21$ & 1200 & $\mathrm{~L}$ & & & & & & & OFF & OFF & OFF & 7" & $18^{\prime \prime}$ & $19^{\prime \prime}$ & 18.75" & \\
\hline $4 / 21$ & 1420 & $\mathrm{~L}$ & 404.8 & 404.1 & & & & & & & & & & & & \\
\hline $4 / 22$ & 835 & $\mathrm{~L}$ & 404.7 & 404.0 & 53 & 58 & 52 & 74 & & & & & & & & \\
\hline $4 / 22$ & 1200 & & & & & & & & OFF & OFF & OFF & 7" & $22.5^{\prime \prime}$ & 22.5" & $22 "$ & \\
\hline $4 / 22$ & 1625 & $\mathrm{~L}$ & 404.7 & 404.1 & & & & & & & & & & & & \\
\hline $4 / 22$ & 1900 & $\mathrm{~L}$ & 404.7 & 404.1 & & & & & & & & & & & & \\
\hline $4 / 23$ & 900 & $\mathrm{~L}$ & 404.7 & 404.1 & 52 & 58 & 43 & 72 & & & & & & & & \\
\hline $4 / 23$ & 1200 & & & & & & & & OFF & OFF & OFF & 7" & $22.5^{\prime \prime}$ & $22.5^{\prime \prime}$ & $22 "$ & \\
\hline $4 / 23$ & 1635 & $\mathrm{~L}$ & 404.7 & 404.1 & & & & & & & & & & & & \\
\hline $4 / 24$ & 900 & $\mathrm{~L}$ & 404.6 & 404.0 & 48 & 54 & 38 & 63 & OFF & OFF & OFF & 7" & $22.5^{\prime \prime}$ & $22.5^{\prime \prime}$ & $22 "$ & \\
\hline $4 / 25$ & 845 & $\mathrm{~L}$ & 404.5 & 403.9 & 48 & 52 & -- & 63 & & & & & & & & \\
\hline $4 / 25$ & 930 & & & & & & & & & & & & $25^{\prime \prime}$ & $25^{\prime \prime}$ & $25^{\prime \prime}$ & \\
\hline $4 / 25$ & 1712 & $\mathrm{~L}$ & 404.5 & 404.0 & & & & & & & & & & & & \\
\hline $4 / 26$ & 900 & $\mathrm{~L}$ & 404.5 & 404.1 & 49 & 53 & 40 & 64 & & & & & & & & \\
\hline $4 / 26$ & 1200 & & & & & & & & OFF & OFF & OFF & 7" & 26.75" & 25.5" & $25.25 "$ & \\
\hline $4 / 27$ & 830 & $\mathrm{~L}$ & 404.5 & 404.0 & 50 & 53 & 45 & 68 & & & & & & & & \\
\hline $4 / 27$ & 1400 & $\mathrm{~L}$ & 404.5 & 404.1 & & & & & & & & & & & & \\
\hline $4 / 27$ & 1430 & $\mathrm{~L}$ & 404.5 & 404.2 & & & & & ON & $\mathrm{ON}$ & OFF & & $26.5^{\prime \prime}$ & $25.25 "$ & $25.25 "$ & \\
\hline $4 / 27$ & 1715 & $\mathrm{~L}$ & 404.5 & 404.2 & & & & & & & & & & & & \\
\hline
\end{tabular}


Appendix Table A-6. Continued.

\begin{tabular}{|c|c|c|c|c|c|c|c|c|c|c|c|c|c|c|c|c|}
\hline \multirow[b]{2}{*}{ Date } & \multirow[b]{2}{*}{ Time } & \multirow[b]{2}{*}{ Debris $^{a}$} & \multirow{2}{*}{$\begin{array}{c}\text { River } \\
\text { gage (ft.) }\end{array}$} & \multirow{2}{*}{$\begin{array}{c}\text { Canal } \\
\text { height (ft.) }\end{array}$} & \multicolumn{2}{|c|}{ Water temp. $\left({ }^{\circ} \mathrm{F}\right)$} & \multicolumn{2}{|c|}{ Air temp. $\left({ }^{\circ} \mathrm{F}\right)$} & \multicolumn{3}{|c|}{ Pumpback Operations $^{b}$} & \multirow{2}{*}{$\begin{array}{l}\text { River-return } \\
\text { pipe opening }\end{array}$} & \multicolumn{3}{|c|}{ Headgate Openings $^{c}$} & \multirow{2}{*}{$\begin{array}{r}\text { Phase } 1 \\
\text { exchange }\end{array}$} \\
\hline & & & & & MIN & MAX & MIN & MAX & $\mathrm{P} 1$ & $\mathrm{P} 2$ & $\mathrm{P} 3$ & & $\mathrm{~S}$ & $\mathrm{M}$ & $\mathrm{N}$ & \\
\hline $4 / 28$ & 910 & $\mathrm{~L}$ & 404.5 & 404.2 & 51 & 52 & 48 & 70 & & & & & & & & \\
\hline $4 / 28$ & 1200 & & & & & & & & $\mathrm{ON}$ & ON & OFF & & $26.75^{\prime \prime}$ & $25.75^{\prime \prime}$ & $25.5^{\prime \prime}$ & \\
\hline $4 / 28$ & 1525 & $\mathrm{~L}$ & 404.5 & 404.2 & & & & & & & & & & & & \\
\hline $4 / 29$ & 830 & $\mathrm{~L}$ & 404.6 & 404.2 & 51 & 55 & 37 & 65 & & & & & & & & \\
\hline $4 / 29$ & 1200 & & & & & & & & $\mathrm{ON}$ & ON & OFF & & $26.5^{\prime \prime}$ & $25.25^{\prime \prime}$ & $25.25 "$ & \\
\hline $4 / 29$ & 1430 & $\mathrm{~L}$ & 404.5 & 404.2 & & & & & & & & & & & & \\
\hline $4 / 30$ & 900 & $\mathrm{~L}$ & 404.5 & 404.2 & 51 & 56 & 45 & 68 & & & & & & & & \\
\hline $4 / 30$ & 1200 & & & & & & & & & & & & $26.5^{\prime \prime}$ & $25.25 "$ & $25.25^{\prime \prime}$ & \\
\hline $4 / 30$ & 1500 & $\mathrm{~L}$ & 404.5 & 404.2 & & & & & & & & & & & & \\
\hline $5 / 1$ & 1200 & & & & & & & & $\mathrm{ON}$ & ON & OFF & & $26.5^{\prime \prime}$ & $25.25^{\prime \prime}$ & $25.25^{\prime \prime}$ & \\
\hline $5 / 1$ & 1800 & $\mathrm{~L}$ & 404.5 & 404.2 & & & & & & & & & & & & \\
\hline $5 / 1$ & 2000 & $\mathrm{~L}$ & 404.4 & 404.1 & & & & & & & & & & & & \\
\hline $5 / 2$ & 800 & $\mathrm{~L}$ & 404.4 & 404.1 & 54 & 60 & 52 & 82 & & & & & & & & \\
\hline $5 / 2$ & 1200 & & & & & & & & ON & ON & OFF & 7" & 26.75" & $25.5^{\prime \prime}$ & $25.5^{\prime \prime}$ & \\
\hline $5 / 2$ & 1530 & $\mathrm{~L}$ & 404.4 & 404.1 & & & & & & & & & & & & \\
\hline $5 / 3$ & 800 & $\mathrm{~L}$ & 404.5 & 404.2 & 54 & 62 & 56 & 72 & & & & & & & & \\
\hline $5 / 3$ & 1200 & & & & & & & & ON & ON & OFF & 7" & $25^{\prime \prime}$ & $25^{\prime \prime}$ & $25^{\prime \prime}$ & \\
\hline $5 / 3$ & 1430 & $\mathrm{~L}$ & 404.5 & 404.2 & & & & & & & & & & & & \\
\hline $5 / 4$ & 800 & $\mathrm{~L}$ & 404.5 & 404.1 & 52 & 62 & 49 & 65 & & & & & & & & \\
\hline $5 / 5$ & 825 & $\mathrm{~L}$ & 404.5 & 404.2 & 44 & 62 & 42 & 79 & & & & & & & & \\
\hline $5 / 5$ & 1200 & & & & & & & & ON & ON & OFF & & $25 "$ & $25^{\prime \prime}$ & $25 "$ & \\
\hline $5 / 5$ & 1200 & & & & & & & & ON & ON & OFF & & $25^{\prime \prime}$ & $25^{\prime \prime}$ & $25^{\prime \prime}$ & \\
\hline $5 / 5$ & 1630 & $\mathrm{~L}$ & 404.5 & 404.3 & & & & & & & & & & & & \\
\hline $5 / 6$ & 800 & $\mathrm{~L}$ & 404.5 & 404.2 & 54 & 60 & 43 & 79 & & & & & & & & \\
\hline $5 / 6$ & 1200 & $\mathrm{~L}$ & & & & & & & ON & ON & OFF & & $25 "$ & $25 "$ & $25 "$ & \\
\hline $5 / 6$ & 1600 & $\mathrm{~L}$ & 404.5 & 404.2 & & & & & & & & & & & & \\
\hline $5 / 7$ & 900 & $\mathrm{~L}$ & 404.5 & 404.2 & 52 & 60 & 42 & 75 & & & & & & & & \\
\hline $5 / 7$ & 1200 & $\mathrm{~L}$ & & & & & & & ON & ON & OFF & & $25^{\prime \prime}$ & $25^{\prime \prime}$ & $25 "$ & \\
\hline $5 / 7$ & 1400 & $\mathrm{~L}$ & 404.5 & 404.2 & & & & & & & & & & & & \\
\hline $5 / 8$ & 800 & $\mathrm{~L}$ & 405.5 & 404.3 & 54 & 58 & 50 & 82 & & & & & & & & \\
\hline $5 / 8$ & 1200 & & & & & & & & $\mathrm{ON}$ & ON & OFF & & $25 "$ & $25 "$ & $25 "$ & \\
\hline $5 / 8$ & 1400 & $\mathrm{~L}$ & 404.5 & 404.2 & & & & & & & & & & & & \\
\hline
\end{tabular}


Appendix Table A-6. Continued.

\begin{tabular}{|c|c|c|c|c|c|c|c|c|c|c|c|c|c|c|c|c|}
\hline \multirow[b]{2}{*}{ Date } & \multirow[b]{2}{*}{ Time } & \multirow[b]{2}{*}{ Debris $^{a}$} & \multirow{2}{*}{$\begin{array}{c}\text { River } \\
\text { gage (ft.) }\end{array}$} & \multirow{2}{*}{$\begin{array}{c}\text { Canal } \\
\text { height (ft.) }\end{array}$} & \multicolumn{2}{|c|}{ Water temp. $\left({ }^{\circ} \mathrm{F}\right)$} & \multicolumn{2}{|c|}{ Air temp. $\left({ }^{\circ} \mathrm{F}\right)$} & \multicolumn{3}{|c|}{ Pumpback Operations $^{b}$} & \multirow{2}{*}{$\begin{array}{l}\text { River-return } \\
\text { pipe opening }\end{array}$} & \multicolumn{3}{|c|}{ Headgate Openings $^{c}$} & \multirow{2}{*}{$\begin{array}{r}\text { Phase } 1 \\
\text { exchange }\end{array}$} \\
\hline & & & & & MIN & MAX & MIN & MAX & $\mathrm{P} 1$ & $\mathrm{P} 2$ & $\mathrm{P} 3$ & & $\mathrm{~S}$ & $\mathrm{M}$ & $\mathrm{N}$ & \\
\hline $5 / 9$ & 900 & $\mathrm{~L}$ & 404.4 & 404.2 & 54 & 63 & 54 & 79 & & & & & & & & \\
\hline $5 / 9$ & 1200 & & & & & & & & $\mathrm{ON}$ & $\mathrm{ON}$ & OFF & & $25 "$ & $25 "$ & $25 "$ & \\
\hline $5 / 9$ & 1400 & $\mathrm{~L}$ & -- & 404.2 & & & & & & & & & & & & Partial \\
\hline $5 / 9$ & 1645 & $\mathrm{~L}$ & -- & 404.2 & & & & & & & & & & & & \\
\hline $5 / 10$ & 915 & $\mathrm{~L}$ & 404.5 & 404.2 & 55 & 62 & 41 & 65 & & & & & & & & \\
\hline $5 / 11$ & 915 & $\mathrm{~L}$ & 404.5 & 404.2 & 53 & 56 & 44 & 61 & & & & & & & & \\
\hline $5 / 11$ & 1200 & & & & & & & & $\mathrm{ON}$ & $\mathrm{ON}$ & OFF & & $25 "$ & $25 "$ & $25 "$ & \\
\hline $5 / 11$ & 1200 & & & & & & & & $\mathrm{ON}$ & $\mathrm{ON}$ & OFF & & $25 "$ & $25 "$ & $25 "$ & \\
\hline $5 / 11$ & 1400 & $\mathrm{~L}$ & 404.5 & 404.2 & & & & & & & & & & & & \\
\hline $5 / 12$ & 932 & $\mathrm{~L}$ & 404.5 & 404.2 & 52 & 53 & 42 & 64 & & & & & & & & \\
\hline $5 / 12$ & 1200 & & & & & & & & ON & ON & OFF & & $25 "$ & $25^{\prime \prime}$ & $25 "$ & \\
\hline $5 / 12$ & 1435 & $\mathrm{~L}$ & 404.5 & 404.2 & & & & & & & & & & & & \\
\hline $5 / 12$ & 1645 & $\mathrm{~L}$ & 404.5 & 404.2 & & & & & & & & & & & & \\
\hline $5 / 13$ & 830 & $\mathrm{~L}$ & 404.5 & 404.2 & 54 & 56 & 51 & 74 & & & & & & & & \\
\hline $5 / 13$ & 1200 & & & & & & & & ON & ON & OFF & & $25 "$ & $25^{\prime \prime}$ & $25 "$ & \\
\hline $5 / 13$ & 1700 & $\mathrm{~L}$ & 404.5 & 404.2 & & & & & & & & & & & & \\
\hline $5 / 14$ & 845 & $\mathrm{~L}$ & 404.5 & 404.3 & 55 & 59 & 53 & 72 & & & & & & & & \\
\hline $5 / 14$ & 1200 & & & & & & & & $\mathrm{ON}$ & $\mathrm{ON}$ & OFF & & $25 "$ & $25^{\prime \prime}$ & $25 "$ & \\
\hline $5 / 14$ & 1400 & $\mathrm{~L}$ & 404.5 & 404.3 & & & & & & & & & & & & \\
\hline $5 / 14$ & 1613 & $\mathrm{~L}$ & 404.6 & 404.3 & & & & & & & & & & & & \\
\hline $5 / 15$ & 1100 & $\mathrm{~L}$ & 404.6 & 404.3 & 56 & 60 & 47 & 77 & & & & & & & & \\
\hline $5 / 15$ & 1200 & & & & & & & & ON & ON & OFF & & $22 "$ & $22 "$ & $22 "$ & \\
\hline $5 / 15$ & 1400 & $\mathrm{~L}$ & 404.6 & 404.2 & & & & & & & & & & & & \\
\hline $5 / 16$ & 900 & $\mathrm{~L}$ & 404.6 & 404.3 & 60 & 62 & 52 & 79 & & & & & & & & \\
\hline $5 / 16$ & 1200 & & & & & & & & ON & $\mathrm{ON}$ & OFF & & $22 "$ & $22 "$ & $22 "$ & \\
\hline $5 / 16$ & 1535 & $\mathrm{~L}$ & 404.7 & 404.3 & & & & & & & & & & & & \\
\hline $5 / 17$ & 900 & $\mathrm{~L}$ & 404.6 & 404.2 & 60 & 62 & 53 & 83 & & & & & & & & \\
\hline $5 / 17$ & 1200 & & & & & & & & ON & $\mathrm{ON}$ & OFF & & $22 "$ & $22 "$ & $22 "$ & \\
\hline $5 / 17$ & 1705 & $\mathrm{~L}$ & 404.5 & 404.3 & & & & & & & & & & & & \\
\hline $5 / 18$ & 900 & $\mathrm{~L}$ & 404.5 & 404.1 & 58 & 61 & 47 & 79 & & & & & & & & \\
\hline $5 / 18$ & 1200 & & & & & & & & ON & $\mathrm{ON}$ & OFF & & $26 "$ & $26 "$ & $26 "$ & \\
\hline $5 / 18$ & 1620 & $\mathrm{~L}$ & 404.5 & 404.1 & & & & & & & & & & & & \\
\hline
\end{tabular}


Appendix Table A-6. Continued.

\begin{tabular}{|c|c|c|c|c|c|c|c|c|c|c|c|c|c|c|c|c|}
\hline \multirow[b]{2}{*}{ Date } & \multirow[b]{2}{*}{ Time } & \multirow[b]{2}{*}{ Debris $^{a}$} & \multirow{2}{*}{$\begin{array}{c}\text { River } \\
\text { gage (ft.) }\end{array}$} & \multirow{2}{*}{$\begin{array}{c}\text { Canal } \\
\text { height (ft.) }\end{array}$} & \multicolumn{2}{|c|}{ Water temp. $\left({ }^{\circ} \mathrm{F}\right)$} & \multicolumn{2}{|c|}{ Air temp. $\left({ }^{\circ} \mathrm{F}\right)$} & \multicolumn{3}{|c|}{ Pumpback Operations $^{b}$} & \multirow{2}{*}{$\begin{array}{l}\text { River-return } \\
\text { pipe opening }\end{array}$} & \multicolumn{3}{|c|}{ Headgate Openings ${ }^{c}$} & \multirow{2}{*}{$\begin{array}{r}\text { Phase } 1 \\
\text { exchange }\end{array}$} \\
\hline & & & & & MIN & MAX & MIN & MAX & $\mathrm{P} 1$ & $\mathrm{P} 2$ & P3 & & $\mathrm{S}$ & M & $\mathrm{N}$ & \\
\hline $5 / 19$ & 857 & $\mathrm{~L}$ & 404.4 & 404.1 & 58 & 62 & 58 & 80 & & & & & & & & \\
\hline $5 / 19$ & 1200 & & & & & & & & ON & ON & OFF & & $26 "$ & $26 "$ & $26 "$ & \\
\hline $5 / 19$ & 1503 & $\mathrm{~L}$ & 404.4 & 404.1 & & & & & & & & & & & & \\
\hline $5 / 20$ & 1200 & & & & & & & & $\mathrm{ON}$ & ON & OFF & & -- & -- & -- & \\
\hline $5 / 20$ & 1430 & $\mathrm{~L}$ & 404.4 & 404.0 & & & & & & & & & & & & \\
\hline $5 / 21$ & 1000 & $\mathrm{~L}$ & 404.4 & 404.1 & 62 & 65 & 52 & 79 & & & & & & & & \\
\hline $5 / 21$ & 1200 & & & & & & & & $\mathrm{ON}$ & ON & OFF & & $26 "$ & $26 "$ & $26 "$ & \\
\hline $5 / 21$ & 1625 & $\mathrm{~L}$ & 404.4 & 404.0 & & & & & & & & & & & & \\
\hline $5 / 22$ & 850 & $\mathrm{~L}$ & 404.5 & 404.4 & 63 & 68 & 61 & 86 & $\mathrm{ON}$ & $\mathrm{ON}$ & OFF & & & & & \\
\hline $5 / 22$ & 1200 & & & & & & & & OFF & OFF & OFF & 7" & $26 "$ & $26^{\prime \prime}$ & $26 "$ & On \\
\hline $5 / 22$ & 1530 & $\mathrm{~L}$ & 404.4 & 404.4 & & & & & & & & & & & & \\
\hline $5 / 23$ & 830 & $\mathrm{~L}$ & 404.4 & 404.5 & 58 & 66 & 60 & 86 & & & & & & & & \\
\hline $5 / 23$ & 1200 & & & & & & & & OFF & OFF & OFF & 7" & $27 "$ & $29 "$ & $30 "$ & \\
\hline $5 / 23$ & 1742 & $\mathrm{~L}$ & 404.4 & 404.4 & & & & & & & & & & & & \\
\hline $5 / 24$ & 828 & $\mathrm{~L}$ & 404.4 & 404.4 & 62 & 68 & 60 & 94 & & & & & & & & \\
\hline $5 / 24$ & 1200 & & & & & & & & OFF & OFF & OFF & 7" & 28.75" & 28.75" & $26.5^{\prime \prime}$ & \\
\hline $5 / 24$ & 1400 & $\mathrm{~L}$ & 404.4 & 404.4 & & & & & & & & & & & & \\
\hline $5 / 25$ & 800 & $\mathrm{~L}$ & 404.4 & 404.4 & 64 & 68 & 53 & 92 & & & & & & & & \\
\hline $5 / 26$ & 800 & $\mathrm{~L}$ & 404.4 & 404.5 & 62 & 64 & 56 & 72 & & & & & & & & \\
\hline $5 / 26$ & 1200 & & & & & & & & OFF & OFF & OFF & 7" & $28.75^{\prime \prime}$ & 26.75" & $26.5^{\prime \prime}$ & \\
\hline $5 / 26$ & 1200 & & & & & & & & OFF & OFF & OFF & 7" & $28.75^{\prime \prime}$ & 26.75" & $26.5^{\prime \prime}$ & \\
\hline $5 / 26$ & 1400 & $\mathrm{~L}$ & 404.4 & 404.5 & & & & & & & & & & & & \\
\hline $5 / 26$ & 1800 & $\mathrm{~L}$ & 404.4 & 404.5 & & & & & & & & & & & & \\
\hline $5 / 27$ & 850 & $\mathrm{~L}$ & 404.4 & 404.4 & 62 & 64 & 54 & 78 & & & & & & & & \\
\hline $5 / 27$ & 1200 & & & & & & & & OFF & OFF & OFF & 7" & $28.75^{\prime \prime}$ & 26.75" & $26.5^{\prime \prime}$ & \\
\hline $5 / 27$ & 1630 & $\mathrm{~L}$ & 404.4 & 404.4 & & & & & & & & & & & & \\
\hline $5 / 29$ & 840 & $\mathrm{~L}$ & 404.4 & 404.4 & 62 & 62 & 52 & 75 & & & & & & & & \\
\hline $5 / 29$ & 1200 & & & & & & & & OFF & OFF & OFF & 7" & $28.75^{\prime \prime}$ & 26.75" & $26.5^{\prime \prime}$ & \\
\hline $5 / 29$ & 1440 & $\mathrm{~L}$ & 404.3 & 404.4 & & & & & & & & & & & & \\
\hline $5 / 30$ & 938 & $\mathrm{~L}$ & 404.4 & 404.4 & 58 & 64 & 48 & 74 & & & & & & & & \\
\hline $5 / 30$ & 1200 & $\mathrm{~L}$ & & & & & & & OFF & OFF & OFF & 7" & $29 "$ & $28.5^{\prime \prime}$ & $26.25 "$ & \\
\hline $5 / 30$ & 1400 & $\mathrm{~L}$ & 404.4 & 404.4 & & & & & & & & & & & & \\
\hline
\end{tabular}


Appendix Table A-6. Continued.

\begin{tabular}{|c|c|c|c|c|c|c|c|c|c|c|c|c|c|c|c|c|}
\hline \multirow[b]{2}{*}{ Date } & \multirow[b]{2}{*}{ Time } & \multirow[b]{2}{*}{ Debris $^{a}$} & \multirow{2}{*}{$\begin{array}{c}\text { River } \\
\text { gage (ft.) }\end{array}$} & \multirow{2}{*}{$\begin{array}{c}\text { Canal } \\
\text { height (ft.) }\end{array}$} & \multicolumn{2}{|c|}{ Water temp. $\left({ }^{\circ} \mathrm{F}\right)$} & \multicolumn{2}{|c|}{ Air temp. $\left({ }^{\circ} \mathrm{F}\right)$} & \multicolumn{3}{|c|}{ Pumpback Operations $^{b}$} & \multirow{2}{*}{$\begin{array}{l}\text { River-return } \\
\text { pipe opening }\end{array}$} & \multicolumn{3}{|c|}{ Headgate Openings $^{c}$} & \multirow{2}{*}{$\begin{array}{r}\text { Phase } 1 \\
\text { exchange }\end{array}$} \\
\hline & & & & & MIN & MAX & MIN & MAX & $\mathrm{P} 1$ & $\mathrm{P} 2$ & $\mathrm{P} 3$ & & $\mathrm{~S}$ & $\mathrm{M}$ & $\mathrm{N}$ & \\
\hline $5 / 31$ & 902 & $\mathrm{~L}$ & 404.4 & 404.4 & 56 & 60 & 48 & 54 & & & & & & & & \\
\hline $5 / 31$ & 1200 & $\mathrm{~L}$ & & & & & & & OFF & OFF & OFF & $7 "$ & $29 "$ & $28.5^{\prime \prime}$ & $26.25 "$ & \\
\hline $5 / 31$ & 1632 & $\mathrm{~L}$ & 404.4 & 404.4 & & & & & & & & & & & & \\
\hline $6 / 1$ & 1430 & M & 404.7 & 404.4 & & & & & OFF & OFF & OFF & $7 "$ & $37 "$ & $36 "$ & $35 "$ & Off \\
\hline $6 / 1$ & 1900 & M & 404.7 & 404.4 & & & & & & & & & & & & \\
\hline $6 / 2$ & 1000 & $\mathrm{~L}$ & 404.5 & 404.3 & 52 & 58 & 47 & 88 & & & & & & & & \\
\hline $6 / 2$ & 1200 & & & & & & & & OFF & OFF & OFF & $7 "$ & $37 "$ & $36 "$ & $35^{\prime \prime}$ & \\
\hline $6 / 2$ & 1400 & $\mathrm{~L}$ & 404.5 & 404.3 & & & & & & & & & & & & \\
\hline $6 / 2$ & 1700 & $\mathrm{~L}$ & 404.5 & 404.3 & & & & & & & & & & & & \\
\hline $6 / 3$ & 836 & $\mathrm{~L}$ & 404.5 & 404.4 & 58 & 60 & 49 & 80 & & & & & & & & \\
\hline $6 / 3$ & 1200 & & & & & & & & OFF & OFF & OFF & 7" & $37 "$ & $36 "$ & $35 "$ & \\
\hline $6 / 3$ & 1428 & $\mathrm{~L}$ & 404.5 & 404.4 & & & & & & & & & & & & \\
\hline $6 / 4$ & 903 & $\mathrm{~L}$ & 404.4 & 404.3 & 60 & 62 & 54 & 75 & & & & & & & & \\
\hline $6 / 4$ & 1200 & & & & & & & & $\mathrm{ON}$ & ON & OFF & & $37 "$ & $36 "$ & $35 "$ & \\
\hline $6 / 4$ & 1400 & $\mathrm{~L}$ & 404.5 & 404.3 & & & & & & & & & & & & \\
\hline $6 / 5$ & 856 & $\mathrm{~L}$ & 404.4 & 404.2 & 62 & 66 & 64 & 89 & & & & & & & & Partial \\
\hline $6 / 5$ & 1200 & & & & & & & & OFF & OFF & OFF & & $37 "$ & $36 "$ & $35^{\prime \prime}$ & \\
\hline $6 / 5$ & 1500 & $\mathrm{~L}$ & 404.4 & 404.2 & & & & & & & & & & & & \\
\hline $6 / 6$ & 900 & $\mathrm{~L}$ & 404.4 & 404.5 & 64 & 68 & 56 & 78 & & & & & & & & \\
\hline $6 / 6$ & 1248 & & & & & & & & OFF & OFF & OFF & 7" & $35^{\prime \prime}$ & $35.5^{\prime \prime}$ & 34.75" & \\
\hline $6 / 6$ & 1400 & $\mathrm{~L}$ & 404.4 & 404.5 & & & & & & & & & & & & \\
\hline $6 / 6$ & 1700 & $\mathrm{~L}$ & 404.4 & 404.5 & & & & & & & & & & & & On \\
\hline $6 / 7$ & 930 & $\mathrm{~L}$ & 404.4 & 404.5 & 63 & 68 & 56 & 78 & & & & & & & & \\
\hline $6 / 7$ & 1200 & & & & & & & & OFF & OFF & OFF & 7" & $35 "$ & $35.25 "$ & 34.75" & \\
\hline $6 / 7$ & 1400 & $\mathrm{~L}$ & 404.4 & 404.5 & & & & & & & & & & & & \\
\hline $6 / 8$ & 900 & $\mathrm{~L}$ & 404.4 & 404.5 & 62 & 69 & -- & 81 & & & & & & & & \\
\hline $6 / 8$ & 1200 & & & & & & & & OFF & OFF & OFF & 7" & $35 "$ & $35.25 "$ & 34.75" & \\
\hline $6 / 8$ & 1400 & $\mathrm{~L}$ & 404.4 & 404.5 & & & & & & & & & & & & \\
\hline $6 / 8$ & 1745 & $\mathrm{~L}$ & 404.4 & 404.5 & & & & & & & & & & & & \\
\hline $6 / 9$ & 930 & $\mathrm{~L}$ & 404.4 & 404.5 & 62 & 64 & 52 & 68 & & & & & & & & \\
\hline $6 / 9$ & 1200 & & & & & & & & OFF & OFF & OFF & 7" & $35 "$ & 36" & $35 "$ & \\
\hline $6 / 9$ & 1415 & $\mathrm{~L}$ & 404.4 & 404.5 & & & & & & & & & & & & \\
\hline
\end{tabular}


Appendix Table A-6. Continued.

\begin{tabular}{|c|c|c|c|c|c|c|c|c|c|c|c|c|c|c|c|c|}
\hline \multirow[b]{2}{*}{ Date } & \multirow[b]{2}{*}{ Time } & \multirow[b]{2}{*}{ Debris $^{a}$} & \multirow{2}{*}{$\begin{array}{c}\text { River } \\
\text { gage (ft.) }\end{array}$} & \multirow{2}{*}{$\begin{array}{c}\text { Canal } \\
\text { height (ft.) }\end{array}$} & \multicolumn{2}{|c|}{ Water temp. $\left({ }^{\circ} \mathrm{F}\right)$} & \multicolumn{2}{|c|}{ Air temp. $\left({ }^{\circ} \mathrm{F}\right)$} & \multicolumn{3}{|c|}{ Pumpback Operations $^{b}$} & \multirow{2}{*}{$\begin{array}{l}\text { River-return } \\
\text { pipe opening }\end{array}$} & \multicolumn{3}{|c|}{ Headgate Openings ${ }^{c}$} & \multirow{2}{*}{$\begin{array}{r}\text { Phase } 1 \\
\text { exchange }\end{array}$} \\
\hline & & & & & MIN & MAX & MIN & MAX & $\mathrm{P} 1$ & $\mathrm{P} 2$ & P3 & & $\mathrm{S}$ & $\mathrm{M}$ & $\mathrm{N}$ & \\
\hline $6 / 10$ & 915 & $\mathrm{~L}$ & 404.5 & 404.5 & 58 & 64 & 48 & 71 & & & & & & & & \\
\hline $6 / 11$ & 830 & $\mathrm{~L}$ & 404.4 & 404.5 & 58 & 62 & 52 & 70 & & & & & & & & \\
\hline $6 / 11$ & 930 & & & & & & & & OFF & OFF & OFF & 7" & $35^{\prime \prime}$ & $35.25^{\prime \prime}$ & $34.75^{\prime \prime}$ & \\
\hline $6 / 11$ & 1200 & & & & & & & & OFF & OFF & OFF & 7" & $35^{\prime \prime}$ & $35.25 "$ & $34.75^{\prime \prime}$ & \\
\hline $6 / 11$ & 1400 & $\mathrm{~L}$ & 404.4 & 404.5 & & & & & & & & & & & & \\
\hline $6 / 11$ & 1630 & $\mathrm{~L}$ & 404.4 & 404.5 & & & & & & & & & & & & \\
\hline $6 / 12$ & 920 & $\mathrm{~L}$ & 404.4 & 404.5 & 59 & 61 & 57 & 65 & & & & & & & & \\
\hline $6 / 12$ & 1200 & & & & & & & & OFF & OFF & OFF & 7" & $35^{\prime \prime}$ & $35.25 "$ & $35.75^{\prime \prime}$ & \\
\hline $6 / 13$ & 840 & $\mathrm{~L}$ & 404.4 & 404.5 & 60 & 60 & 54 & 73 & & & & & & & & \\
\hline $6 / 13$ & 1200 & & & & & & & & OFF & OFF & OFF & 7" & $35^{\prime \prime}$ & $35.25 "$ & 35.75" & \\
\hline $6 / 13$ & 1530 & $\mathrm{~L}$ & 404.5 & 404.5 & & & & & & & & & & & & \\
\hline $6 / 13$ & 1630 & $\mathrm{~L}$ & 404.4 & 404.5 & & & & & & & & & & & & \\
\hline $6 / 14$ & 845 & $\mathrm{~L}$ & 404.6 & 404.5 & 61 & 64 & 62 & 82 & & & & & & & & \\
\hline $6 / 14$ & 1200 & & & & & & & & OFF & OFF & OFF & 7" & $35^{\prime \prime}$ & $35.25 "$ & $34.75^{\prime \prime}$ & \\
\hline $6 / 14$ & 1518 & $\mathrm{~L}$ & 404.6 & 404.6 & & & & & & & & & & & & \\
\hline $6 / 15$ & 900 & $\mathrm{M}$ & 404.3 & 404.1 & 62 & 69 & 57 & 86 & & & & & & & & Off \\
\hline $6 / 15$ & 1230 & & & & & & & & OFF & OFF & OFF & 7" & $39^{\prime \prime}$ & 38.75" & 38.75" & \\
\hline $6 / 16$ & 900 & M & 404.3 & 404.1 & 59 & 71 & 50 & 88 & & & & & & & & On \\
\hline $6 / 16$ & 1200 & & & & & & & & OFF & OFF & OFF & 7" & $39^{\prime \prime}$ & $38.75^{\prime \prime}$ & $38.75^{\prime \prime}$ & \\
\hline $6 / 16$ & 1439 & $\mathrm{~L}$ & 403.9 & 403.8 & & & & & & & & & & & & \\
\hline $6 / 16$ & 1630 & $\mathrm{M}$ & 404.3 & 404.1 & & & & & & & & & & & & \\
\hline $6 / 17$ & 832 & $\mathrm{~L}$ & 404.3 & 404.0 & 62 & 68 & 52 & 96 & & & & & & & & \\
\hline $6 / 17$ & 1200 & & & & & & & & OFF & OFF & OFF & 7" & $33 "$ & $33.75^{\prime \prime}$ & $31.5^{\prime \prime}$ & \\
\hline $6 / 17$ & 1630 & $\mathrm{M}$ & 404.6 & 404.6 & & & & & & & & & & & & \\
\hline $6 / 17$ & 1630 & $\mathrm{~L}$ & 404.3 & 404.1 & & & & & & & & & & & & \\
\hline $6 / 18$ & 850 & $\mathrm{~L}$ & 404.4 & 404.5 & 64 & 70 & 58 & 91 & & & & & & & & \\
\hline $6 / 18$ & 1200 & & & & & & & & OFF & OFF & OFF & 7" & $33 "$ & $33.75^{\prime \prime}$ & $31.5^{\prime \prime}$ & \\
\hline $6 / 18$ & 1430 & $\mathrm{~L}$ & 404.4 & 404.5 & & & & & & & & & & & & \\
\hline $6 / 19$ & 1200 & & & & & & & & OFF & OFF & OFF & 7" & $33^{\prime \prime}$ & $33.75^{\prime \prime}$ & $31.5^{\prime \prime}$ & \\
\hline $6 / 19$ & 1430 & $\mathrm{~L}$ & 404.4 & & & & & & & & & & & & & \\
\hline $6 / 19$ & 905 & $\mathrm{~L}$ & 404.4 & 404.5 & 64 & 71 & 55 & 90 & & & & & & & & \\
\hline $6 / 20$ & 930 & $\mathrm{~L}$ & 404.4 & 404.4 & 63 & 69 & 52 & 90 & & & & & & & & \\
\hline
\end{tabular}


Appendix Table A-6. Continued.

\begin{tabular}{|c|c|c|c|c|c|c|c|c|c|c|c|c|c|c|c|c|}
\hline \multirow[b]{2}{*}{ Date } & \multirow[b]{2}{*}{ Time } & \multirow[b]{2}{*}{ Debris $^{a}$} & \multirow{2}{*}{$\begin{array}{c}\text { River } \\
\text { gage (ft.) }\end{array}$} & \multirow{2}{*}{$\begin{array}{c}\text { Canal } \\
\text { height (ft.) }\end{array}$} & \multicolumn{2}{|c|}{ Water temp. $\left({ }^{\circ} \mathrm{F}\right)$} & \multicolumn{2}{|c|}{ Air temp. $\left({ }^{\circ} \mathrm{F}\right)$} & \multicolumn{3}{|c|}{ Pumpback Operations $^{b}$} & \multirow{2}{*}{$\begin{array}{l}\text { River-return } \\
\text { pipe opening }\end{array}$} & \multicolumn{3}{|c|}{ Headgate Openings $^{c}$} & \multirow{2}{*}{$\begin{array}{r}\text { Phase } 1 \\
\text { exchange }\end{array}$} \\
\hline & & & & & MIN & MAX & MIN & MAX & $\mathrm{P} 1$ & P2 & P3 & & $\mathrm{S}$ & $\mathrm{M}$ & $\mathrm{N}$ & \\
\hline $6 / 20$ & 1200 & & & & & & & & OFF & OFF & OFF & $7 "$ & $33.5^{\prime \prime}$ & $34 "$ & $31.5^{\prime \prime}$ & \\
\hline $6 / 20$ & 1430 & $\mathrm{~L}$ & 404.4 & 404.5 & & & & & & & & & & & & \\
\hline $6 / 21$ & 845 & $\mathrm{~L}$ & 404.4 & 404.4 & 63 & 68 & 60 & 86 & & & & & & & & \\
\hline $6 / 21$ & 1630 & & 404.4 & 404.5 & & & & & & & & & & & & \\
\hline $6 / 22$ & 915 & $\mathrm{~L}$ & 404.3 & 404.4 & 67 & 71 & 57 & 92 & & & & & & & & \\
\hline $6 / 22$ & 1600 & $\mathrm{~L}$ & 404.4 & 404.4 & & & & & OFF & OFF & OFF & 7" & $33.5^{\prime \prime}$ & $34 "$ & $31.5^{\prime \prime}$ & \\
\hline $6 / 24$ & 845 & $\mathrm{~L}$ & 404.4 & 404.5 & 68 & 71 & 55 & 87 & & & & & & & & \\
\hline $6 / 24$ & 1300 & & & & & & & & OFF & OFF & OFF & 7" & $33.5^{\prime \prime}$ & $34 "$ & $31.5^{\prime \prime}$ & \\
\hline $6 / 25$ & 830 & L & 404.4 & 404.5 & 66 & 70 & 57 & 84 & & & & & & & & \\
\hline $6 / 25$ & 1200 & & & & & & & & OFF & OFF & OFF & 7" & $33.5^{\prime \prime}$ & $33.5^{\prime \prime}$ & $31.5^{\prime \prime}$ & \\
\hline $6 / 26$ & 946 & $\mathrm{~L}$ & 404.4 & 404.4 & 66 & 70 & 52 & 84 & OFF & OFF & OFF & 7" & $33.5^{\prime \prime}$ & $33.5^{\prime \prime}$ & 31.5" & \\
\hline $6 / 26$ & 1200 & & & & & & & & OFF & OFF & OFF & 7" & $33.5^{\prime \prime}$ & $33.5^{\prime \prime}$ & 31.5" & \\
\hline $6 / 27$ & 835 & $\mathrm{~L}$ & 404.4 & 404.4 & 66 & 72 & 58 & 92 & OFF & OFF & OFF & 7" & 33.5" & $33.5^{\prime \prime}$ & 31.5" & \\
\hline $6 / 29$ & 900 & $\mathrm{~L}$ & 404.4 & 404.4 & 68 & 70 & 62 & 92 & OFF & OFF & OFF & $5^{\prime \prime}$ & 32" & $33.5^{\prime \prime}$ & 31.5" & \\
\hline $6 / 30$ & 840 & $\mathrm{H}$ & 404.2 & 405.1 & 70 & 75 & 62 & 98 & & & & & & & & \\
\hline $6 / 30$ & 930 & $\mathrm{~L}$ & 404.4 & 404.4 & 70 & & 60 & 108 & OFF & OFF & OFF & 5" & $32 "$ & $33.5^{\prime \prime}$ & 31.5" & Off \\
\hline $7 / 1$ & 905 & & & & & & & & $\mathrm{ON}$ & ON & OFF & & $32 "$ & 33.5" & 31.5" & \\
\hline $7 / 1$ & 1030 & M & 404.3 & 404.2 & 68 & 72 & 62 & 98 & ON & ON & OFF & & $32 "$ & $33.5^{\prime \prime}$ & 31.5" & \\
\hline $7 / 3$ & 945 & $\mathrm{M}$ & 404.3 & 404.1 & 65 & 71 & 52 & 92 & ON & ON & OFF & & $32 "$ & $33.5^{\prime \prime}$ & 31.5" & \\
\hline $7 / 4$ & 830 & $\mathrm{~L}$ & 404.3 & 404.2 & 62 & 66 & 53 & 74 & OFF & OFF & OFF & & $33.5^{\prime \prime}$ & $33.5^{\prime \prime}$ & 31.5" & \\
\hline $7 / 4$ & 1100 & $\mathrm{~L}$ & 404.3 & 404.2 & 63 & 68 & 68 & 78 & OFF & OFF & OFF & & 32" & $33.5^{\prime \prime}$ & 31.5" & \\
\hline $7 / 6$ & 1200 & & 404.3 & 404.2 & & & & & & & & & & & & \\
\hline $7 / 7$ & 1400 & $\mathrm{~L}$ & 404.3 & 404.2 & 59 & 68 & 63 & 77 & OFF & OFF & OFF & & $32 "$ & $33.25 "$ & 31.5" & \\
\hline $7 / 9$ & 1005 & $\mathrm{~L}$ & 404.3 & 404.2 & 66 & 68 & 57 & 100 & OFF & OFF & OFF & & & & & \\
\hline $7 / 10$ & 1100 & $\mathrm{~L}$ & 404.2 & 404.1 & 63 & 72 & 57 & 100 & OFF & OFF & OFF & & $33.5^{\prime \prime}$ & $33.5^{\prime \prime}$ & $31.5^{\prime \prime}$ & On \\
\hline $7 / 12$ & 830 & $\mathrm{~L}$ & 404.2 & 404.1 & 67 & 70 & 55 & 93 & OFF & OFF & OFF & & & & & \\
\hline $7 / 13$ & 1030 & $\mathrm{~L}$ & 403.7 & 403.7 & 68 & 72 & 58 & 93 & & & & & & & & \\
\hline $7 / 16$ & 800 & & 403.4 & 403.4 & 72 & 72 & 62 & 104 & & & & & $32 "$ & $33.5^{\prime \prime}$ & $31.5^{\prime \prime}$ & \\
\hline $7 / 17$ & 900 & $\mathrm{~L}$ & 404.2 & 404.1 & 68 & 74 & 52 & 99 & OFF & ON & OFF & & 33.5" & $33.5^{\prime \prime}$ & 31.5" & \\
\hline $7 / 19$ & 1430 & & 404.3 & 404.2 & 67 & 71 & 60 & 98 & OFF & ON & OFF & & & & & \\
\hline $7 / 20$ & 945 & $\mathrm{~L}$ & 404.1 & 404.0 & 72 & 74 & 62 & 99 & OFF & ON & OFF & & $33.5^{\prime \prime}$ & $33.5^{\prime \prime}$ & 31.5" & \\
\hline $7 / 21$ & 1115 & $\mathrm{~L}$ & 404.2 & 404.2 & 70 & 72 & 63 & 92 & OFF & $\mathrm{ON}$ & OFF & & & & & \\
\hline
\end{tabular}


Appendix Table A-6. Continued.

\begin{tabular}{|c|c|c|c|c|c|c|c|c|c|c|c|c|c|c|c|c|}
\hline \multirow[b]{2}{*}{ Date } & \multirow[b]{2}{*}{ Time } & \multirow[b]{2}{*}{ Debris $^{a}$} & \multirow{2}{*}{$\begin{array}{c}\text { River } \\
\text { gage (ft.) }\end{array}$} & \multirow{2}{*}{$\begin{array}{c}\text { Canal } \\
\text { height (ft.) }\end{array}$} & \multicolumn{2}{|c|}{ Water temp. $\left({ }^{\circ} \mathrm{F}\right)$} & \multicolumn{2}{|c|}{ Air temp. $\left({ }^{\circ} \mathrm{F}\right)$} & \multicolumn{3}{|c|}{ Pumpback Operations $^{b}$} & \multirow{2}{*}{$\begin{array}{l}\text { River-return } \\
\text { pipe opening }\end{array}$} & \multicolumn{3}{|c|}{ Headgate Openings $^{c}$} & \multirow{2}{*}{$\begin{array}{r}\text { Phase 1 } \\
\text { exchange }\end{array}$} \\
\hline & & & & & MIN & MAX & MIN & MAX & P1 & $\mathrm{P} 2$ & P3 & & $\mathrm{S}$ & $\mathrm{M}$ & $\mathrm{N}$ & \\
\hline $7 / 23$ & 0800 & $\mathrm{~L}$ & 404.2 & 404.2 & 70 & 72 & 63 & 101 & OFF & ON & OFF & & $32 "$ & $33.5^{\prime \prime}$ & $31.5^{\prime \prime}$ & \\
\hline $7 / 25$ & 1600 & $\mathrm{~L}$ & 404.2 & 404.2 & 72 & 74 & 58 & 104 & OFF & ON & OFF & & $32 ”$ & $33.5^{\prime \prime}$ & $31.5^{\prime \prime}$ & \\
\hline $7 / 27$ & 1415 & $\mathrm{~L}$ & 404.2 & 404.2 & 71 & 72 & 59 & 96 & OFF & ON & OFF & & $33.5^{\prime \prime}$ & $33.5^{\prime \prime}$ & $31.5 \%$ & \\
\hline $7 / 28$ & 1100 & $\mathrm{~L}$ & 404.2 & 404.2 & 69 & 72 & & 98 & OFF & ON & OFF & & $33.5 ”$ & $33.5^{\prime \prime}$ & $31.5^{\prime \prime}$ & \\
\hline $7 / 31$ & 0930 & $\mathrm{~L}$ & 404.1 & 404.1 & 70 & 71 & & 94 & OFF & ON & OFF & & $33.5^{\prime \prime}$ & $33.5^{\prime \prime}$ & $31.5^{\prime \prime}$ & \\
\hline $8 / 7$ & 1300 & $\mathrm{~L}$ & 404.3 & 4043 & 71 & 73 & 68 & 116 & OFF & ON & OFF & & $32 "$ & $33.5^{\prime \prime}$ & 31.5" & \\
\hline $8 / 8$ & 1400 & $\mathrm{~L}$ & 404.2 & 404.2 & 72 & 74 & 66 & 102 & OFF & ON & OFF & & & & & \\
\hline $8 / 10$ & 1030 & $\mathrm{~L}$ & 404.2 & 404.2 & 72 & 72 & 65 & 106 & OFF & ON & OFF & & $33.5^{\prime \prime}$ & $33.5 "$ & $31.5 "$ & \\
\hline $8 / 16$ & 1530 & $\mathrm{~L}$ & 404.2 & 404.2 & 71 & 73 & 69 & 103 & OFF & ON & OFF & & $33.5^{\prime \prime}$ & $33.5^{\prime \prime}$ & 31.5" & \\
\hline $8 / 18$ & 1015 & 1 & 404.4 & 404.4 & 68 & 72 & 56 & 91 & OFF & ON & OFF & & $32 "$ & $33.5^{\prime \prime}$ & $31.5^{\prime \prime}$ & \\
\hline $8 / 23$ & 1500 & $\mathrm{~L}$ & 404.3 & 404.4 & 67 & 68 & 55 & 97 & OFF & OFF & OFF & 7" & $33.5^{\prime \prime}$ & $33.5^{\prime \prime}$ & $31.5^{\prime \prime}$ & \\
\hline $8 / 25$ & 1500 & $\mathrm{~L}$ & 404.3 & 404.4 & 66 & 68 & 54 & 95 & OFF & OFF & OFF & 7" & $33.5^{\prime \prime}$ & $33.5^{\prime \prime}$ & 31.5" & \\
\hline $8 / 28$ & 1530 & $\mathrm{~L}$ & 404.4 & 404.4 & 62 & 63 & 64 & 98 & OFF & ON & OFF & & $33.5^{\prime \prime}$ & $33.5^{\prime \prime}$ & 31.5" & \\
\hline $8 / 30$ & 0845 & $\mathrm{~L}$ & 404.4 & 404.4 & 64 & 72 & 54 & 94 & OFF & ON & OFF & & $33.5^{\prime \prime}$ & $33.5^{\prime \prime}$ & 31.5" & \\
\hline $9 / 1$ & 0900 & $\mathrm{H}$ & 404.4 & 404.4 & 62 & 68 & 54 & 854 & OFF & ON & OFF & & $33.5^{\prime \prime}$ & $33.5^{\prime \prime}$ & $31.5^{\prime \prime}$ & \\
\hline $9 / 3$ & 1330 & $\mathrm{~L}$ & 404.4 & 404.4 & 65 & 70 & 59 & 94 & OFF & ON & OFF & & 33.5" & $33.5^{\prime \prime}$ & $31.5^{\prime \prime}$ & \\
\hline $9 / 5$ & 1400 & $\mathrm{~L}$ & 404.4 & 404.5 & 62 & 68 & 48 & 74 & OFF & ON & OFF & & $33.5^{\prime \prime}$ & $33.5^{\prime \prime}$ & 31.5" & \\
\hline $9 / 8$ & 0845 & $\mathrm{~L}$ & 404.4 & 404.5 & 62 & 65 & 57 & 80 & OFF & ON & OFF & & $33.5^{\prime \prime}$ & $33.5^{\prime \prime}$ & 31.5" & \\
\hline $9 / 10$ & 1500 & $\mathrm{~L}$ & 404.4 & 404.5 & 63 & 67 & 55 & 86 & OFF & ON & OFF & & $33.5^{\prime \prime}$ & $33.5^{\prime \prime}$ & $31.5^{\prime \prime}$ & \\
\hline $9 / 12$ & 1045 & $\mathrm{~L}$ & 404.4 & 404.5 & 62 & 65 & 52 & 79 & OFF & $\mathrm{ON}$ & OFF & & $33.5^{\prime \prime}$ & $33.5^{\prime \prime}$ & $31.5^{\prime \prime}$ & \\
\hline $9 / 14$ & 1030 & $\mathrm{~L}$ & 404.4 & 404.4 & 63 & 66 & 60 & 88 & OFF & OFF & OFF & 7" & $33.5^{\prime \prime}$ & $33.5^{\prime \prime}$ & $31.5^{\prime \prime}$ & \\
\hline $9 / 17$ & 1530 & & 404.4 & 404.4 & 65 & 70 & 62 & 90 & OFF & OFF & OFF & 7" & $33.5^{\prime \prime}$ & $33.5^{\prime \prime}$ & $31.5^{\prime \prime}$ & \\
\hline $9 / 19$ & 1630 & $\mathrm{~L}$ & 404.4 & 404.5 & 68 & 70 & 62 & 94 & OFF & OFF & OFF & 7" & $33.5^{\prime \prime}$ & $33.5^{\prime \prime}$ & $31.5^{\prime \prime}$ & \\
\hline $9 / 21$ & 1600 & M & 404.4 & 404.5 & 66 & 68 & 65 & 98 & OFF & OFF & OFF & 7" & $33.5^{\prime \prime}$ & $33.5^{\prime \prime}$ & 31.5" & \\
\hline $9 / 24$ & 1420 & M & 404.4 & 404.5 & 64 & 70 & 53 & 89 & OFF & OFF & OFF & 7" & $33.5^{\prime \prime}$ & $33.5^{\prime \prime}$ & $31.5^{\prime \prime}$ & \\
\hline $9 / 26$ & 1030 & M & 404.4 & 404.5 & 56 & 64 & 37 & 68 & OFF & OFF & OFF & $7 "$ & $33.5^{\prime \prime}$ & $33.5^{\prime \prime}$ & $31.5^{\prime \prime}$ & \\
\hline $9 / 29$ & 1230 & M & 404.4 & 404.5 & 55 & 58 & 43 & 80 & OFF & OFF & OFF & $7 "$ & $33.5^{\prime \prime}$ & $33.5^{\prime \prime}$ & $31.5^{\prime \prime}$ & \\
\hline
\end{tabular}


Appendix Table A-7. Estimates of survival and/or abundance for hatchery and natural juvenile salmonids migrating from the Umatilla River basin, 1995 - 2000.

\begin{tabular}{|c|c|c|c|c|c|c|}
\hline \multirow[b]{2}{*}{ Species $^{a}$} & \multicolumn{6}{|c|}{ Year } \\
\hline & 1995 & 1996 & 1997 & 1998 & 1999 & 2000 \\
\hline \multicolumn{7}{|c|}{ Survival (95\% C.I.) } \\
\hline $\mathrm{HCH} 1^{+}$ & $426 \%$ & -- & $71 \%( \pm 31.1 \%)$ & -- & -- & -- \\
\hline $\mathrm{HCHS} 0^{+}$ & $3 \%$ & -- & -- & -- & -- & -- \\
\hline $\mathrm{HCHS} 1^{+}$ & $67 \%$ & $34 \%( \pm 76 \%)$ & -- & $73 \%( \pm 7 \%)$ & $48 \%( \pm 10 \%)$ & $35 \%( \pm 14 \%)$ \\
\hline $\mathrm{HCHF} 1^{+}$ & -- & $40 \%( \pm 5 \%)$ & -- & $70 \%( \pm 15 \%)$ & $110 \%( \pm 44 \%)$ & $41 \%( \pm 13 \%)$ \\
\hline $\mathrm{HCHF} 0^{+}$ & $18 \%$ & $141 \%( \pm 4 \%)$ & $35 \%( \pm 5 \%)$ & $152 \%( \pm 7 \%)$ & $53 \%( \pm 5 \%)$ & $65 \%( \pm 6 \%)$ \\
\hline $\mathrm{HCOH}$ & $2,243 \%$ & $38 \%( \pm 6 \%)$ & $34 \%( \pm 19 \%)$ & $129 \%( \pm 11 \%)$ & -- & -- \\
\hline HSTS & $154 \%$ & $94 \%( \pm 10 \%)$ & -- & $50 \%( \pm 7 \%)$ & $63 \%( \pm 14 \%)$ & $56 \%( \pm 23 \%)$ \\
\hline $\mathrm{NCH}$ & & & & & $43 \%( \pm 18 \%)$ & $5 \%( \pm 9 \%)$ \\
\hline NSTS & & & & & $32 \%( \pm 6 \%)$ & $60 \%( \pm 30 \%)$ \\
\hline $\mathrm{NCOH}$ & & & & & & $14 \%( \pm 4 \%)$ \\
\hline \multicolumn{7}{|c|}{ Abundance } \\
\hline $\mathrm{NCH}$ & -- & -- & -- & -- & -- & 46,764 \\
\hline NCHS & 74,342 & 1,856 & 1,151 & 18,724 & 19,414 & -- \\
\hline $\mathrm{NCHF}$ & -- & -- & 1,318 & 124,504 & 1,155 & -- \\
\hline $\mathrm{NCOH}$ & -- & 346 & 1,200 & 3,384 & 2,708 & 30,163 \\
\hline NSTS & 58,876 & 73,134 & -- & 53,854 & 45,513 & 81,759 \\
\hline
\end{tabular}

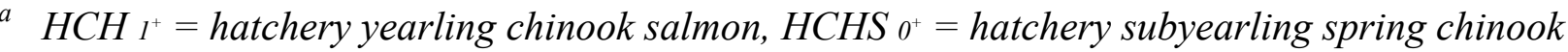
salmon, $\mathrm{HCHS} \mathrm{I}^{+}=$hatchery yearling spring chinook salmon, $\mathrm{HCHF} \mathrm{I}^{+}=$hatchery yearling fall chinook salmon, $\mathrm{HCHF} \mathrm{O}^{+}=$hatchery subyearling fall chinook salmon, $\mathrm{HCOH}=$ hatchery coho salmon, HSTS = hatchery summer steelhead, NCH = natural chinook salmon, NCHS = natural spring chinook salmon, $N C H F=$ natural fall chinook salmon, $N C O H=$ natural coho salmon, and NSTS = natural summer steelhead. 
Appendix Table 8. Detection, abundance, and survival of PIT-tagged production fish released into the upper Umatilla River and detected in the lower river, December 1998 - July 1999.

Abundance estimates recalculated based on methods used in 2000.

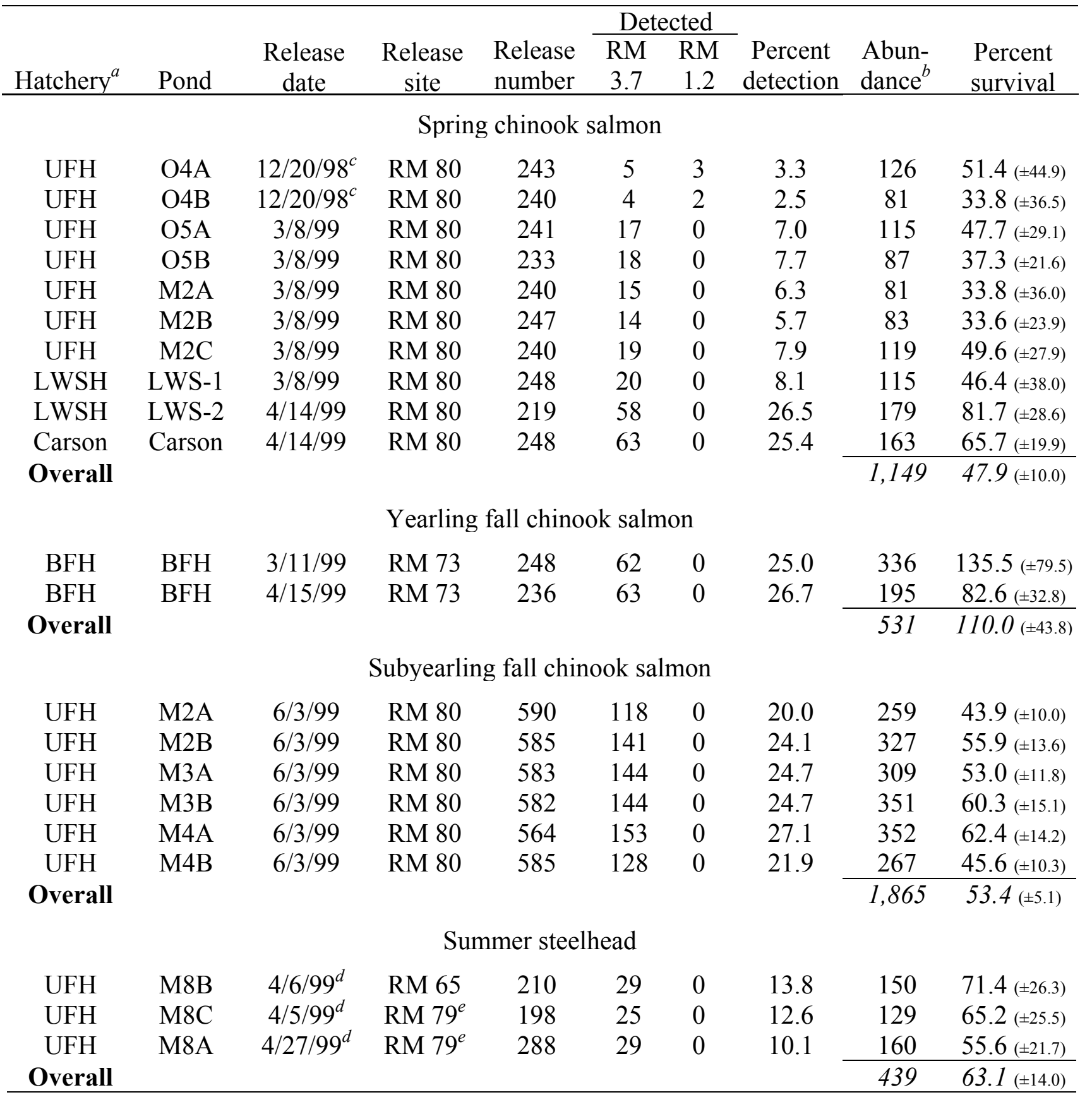

a $U F H=$ Umatilla Fish Hatchery, LWSH = Little White Salmon Hatchery, Carson = Carson National Fish Hatchery, BFH = Bonneville Fish Hatchery.

$b$ Abundance was estimated from number of detections and the trap efficiency estimate (running average) for the period in which fish were detected.

$c$ Fish were emergency released from the acclimation pond due to ice.

$d$ Beginning of volitional release for summer steelhead.

e Rivermile 2 of Meacham Creek at rivermile 79 of Umatilla River. 
Appendix Table A-9. Number and mean percent detection of PIT-tagged fish released for reach-specific survival and transport evaluation tests and interrogated in the lower Umatilla River (RM 3.7) and on the mainstem lower Columbia River, 1998 - 2000.

\begin{tabular}{|c|c|c|c|c|c|c|c|c|}
\hline \multirow[b]{2}{*}{ Year } & \multirow{2}{*}{$\begin{array}{c}\text { Release } \\
\text { date }\end{array}$} & \multirow{2}{*}{$\begin{array}{c}\text { Release } \\
\text { site }\end{array}$} & \multirow{2}{*}{$\begin{array}{l}\text { Release } \\
\text { number }\end{array}$} & \multicolumn{2}{|c|}{ Number detected } & \multicolumn{3}{|c|}{ Mean percent detection } \\
\hline & & & & RM 3.7 & Mainstem & RM 3.7 & Main. & Total \\
\hline \multicolumn{9}{|c|}{ Spring Chinook Salmon } \\
\hline \multirow[t]{3}{*}{1998} & $3 / 9-3 / 11$ & RM 80 & 238 & 2 & 24 & 0.8 & 10.0 & 10.9 \\
\hline & $3 / 9-3 / 11$ & RM 42 & 232 & 4 & 30 & 1.7 & 13.0 & 14.7 \\
\hline & $3 / 9-3 / 11$ & RM 27 & 226 & 3 & 42 & 1.4 & 18.5 & 19.9 \\
\hline \multirow[t]{4}{*}{1999} & $3 / 9-3 / 11$ & RM 80 & 252 & 16 & 18 & 6.2 & 7.2 & 13.4 \\
\hline & $3 / 9-3 / 11$ & RM 48 & 250 & 13 & 20 & 5.3 & 8.1 & 13.4 \\
\hline & $3 / 9-3 / 11$ & RM 27 & 257 & 12 & 30 & 4.8 & 12.0 & 16.8 \\
\hline & $3 / 9-3 / 11$ & RM 11 & 246 & 12 & 43 & 4.9 & 17.3 & 22.2 \\
\hline \multirow[t]{3}{*}{2000} & $3 / 7-3 / 9$ & RM 80 & 1,002 & 10 & 183 & 1.0 & 18.3 & 19.3 \\
\hline & $3 / 7-3 / 9$ & RM 27 & 1,000 & 10 & 241 & 1.0 & 24.1 & 25.1 \\
\hline & $3 / 7-3 / 9$ & RM 9 & 777 & 11 & 209 & 1.3 & 26.6 & 27.9 \\
\hline
\end{tabular}

Subyearling Fall Chinook Salmon

$\begin{array}{rcccccccr}1998 & 6 / 1-6 / 3 & \text { RM 80 } & 491 & 19 & 33 & 3.9 & 6.7 & 10.6 \\ & 6 / 1-6 / 3 & \text { RM 48 } & 518 & 22 & 38 & 4.2 & 7.3 & 11.5 \\ & 6 / 1-6 / 3 & \text { RM 27 } & 505 & 16 & 46 & 3.2 & 9.1 & 12.4 \\ & 7 / 7-7 / 9^{a} & \text { RM 0 } & 481 & - & 5 & - & 1.1 & 1.1 \\ 1999 & & & & & & & & \\ & 6 / 3-6 / 5 & \text { RM 80 } & 498 & 99 & 43 & 19.9 & 8.6 & 28.5 \\ & 6 / 3-6 / 5 & \text { RM 48 } & 477 & 117 & 43 & 24.6 & 9.1 & 33.6 \\ & 6 / 3-6 / 5 & \text { RM 27 } & 482 & 122 & 52 & 25.2 & 10.8 & 36.0 \\ & 6 / 3-6 / 5 & \text { RM 9 } & 537 & 87 & 63 & 15.9 & 11.8 & 27.6 \\ & 7 / 20-7 / 26^{a} & \text { RM 0 } & 428 & - & 41 & - & 9.7 & 9.7 \\ & & & & & & & & \\ & 5 / 23-5 / 25 & \text { RM 74 } & 447 & 98 & 18 & 21.9 & 4.0 & 25.9 \\ & 5 / 23-5 / 25 & \text { RM 56 } & 448 & 121 & 26 & 27.0 & 5.8 & 32.8 \\ & 5 / 23-5 / 25 & \text { RM 27 } & 446 & 126 & 34 & 28.3 & 7.6 & 36.0 \\ & 5 / 23-5 / 25 & \text { RM 9 } & 596 & 177 & 49 & 29.7 & 8.3 & 38.0 \\ & 5 / 23-5 / 25 & \text { RM 0 } & 1,892 & - & 297 & - & 15.7 & 15.7\end{array}$

Summer Steelhead ${ }^{b}$

\begin{tabular}{lllllllll}
1998 & $4 / 15-4 / 17$ & RM 79 & 240 & 4 & 44 & 1.2 & 16.3 & 17.5 \\
& $4 / 15-4 / 17$ & RM 65 & 206 & 4 & 42 & 1.4 & 20.3 & 21.7 \\
\hline
\end{tabular}

a Subyearling fall chinook release for transport evaluation.

${ }^{b}$ Early-released steelhead are large-grade; late-released steelhead are small-grade. 
Appendix Table A-9. Continued.

\begin{tabular}{|c|c|c|c|c|c|c|c|c|}
\hline \multirow[b]{2}{*}{ Year } & \multirow{2}{*}{$\begin{array}{l}\text { Release } \\
\text { date }\end{array}$} & \multirow{2}{*}{$\begin{array}{c}\text { Release } \\
\text { site }\end{array}$} & \multirow{2}{*}{$\begin{array}{l}\text { Release } \\
\text { number }\end{array}$} & \multicolumn{2}{|c|}{ Number detected } & \multicolumn{3}{|c|}{ Mean percent detection } \\
\hline & & & & RM 3.7 & Mainstem & WEID & Main. & Total \\
\hline \multicolumn{9}{|c|}{ Summer Steelhead - continued } \\
\hline \multirow[t]{5}{*}{1998} & $4 / 15-4 / 17$ & RM 48 & 228 & 8 & 60 & 3.3 & 26.4 & 30.0 \\
\hline & $4 / 15-4 / 17$ & RM 27 & 208 & 6 & 52 & 2.4 & 24.9 & 27.3 \\
\hline & $5 / 11-5 / 13$ & RM 79 & 221 & 4 & 34 & 1.8 & 14.9 & 16.7 \\
\hline & $5 / 11-5 / 13$ & RM 48 & 239 & 7 & 36 & 2.9 & 14.9 & 17.9 \\
\hline & $5 / 11-5 / 13$ & RM 27 & 240 & 7 & 46 & 2.9 & 19.2 & 22.1 \\
\hline \multirow[t]{9}{*}{1999} & $4 / 12-4 / 15$ & RM 79 & 187 & 19 & 13 & 10.1 & 6.9 & 17.0 \\
\hline & $4 / 12-4 / 15$ & RM 65 & 224 & 25 & 27 & 11.6 & 12.1 & 23.7 \\
\hline & $4 / 12-4 / 15$ & RM 48 & 220 & 38 & 25 & 16.9 & 11.6 & 28.5 \\
\hline & $4 / 12-4 / 15$ & RM 27 & 219 & 48 & 32 & 21.9 & 15.5 & 37.4 \\
\hline & $4 / 12-4 / 15$ & RM 9 & 229 & 65 & 35 & 27.7 & 16.2 & 43.9 \\
\hline & $5 / 4-5 / 7$ & RM 79 & 238 & 10 & 8 & 4.2 & 3.4 & 7.6 \\
\hline & $5 / 4-5 / 7$ & RM 48 & 242 & 33 & 14 & 13.6 & 5.7 & 19.2 \\
\hline & $5 / 4-5 / 7$ & RM 27 & 245 & 41 & 15 & 16.4 & 6.0 & 22.4 \\
\hline & $5 / 4-5 / 7$ & RM 9 & 243 & 64 & 20 & 26.2 & 8.6 & 34.8 \\
\hline \multirow[t]{5}{*}{2000} & $4 / 10-4 / 12$ & RM 79 & 569 & 61 & 27 & 10.7 & 4.7 & 15.5 \\
\hline & $4 / 10-4 / 12$ & RM 65 & 569 & 48 & 26 & 8.4 & 4.6 & 13.0 \\
\hline & $4 / 10-4 / 12$ & RM 48 & 563 & 68 & 28 & 12.1 & 4.9 & 17.0 \\
\hline & $4 / 10-4 / 12$ & RM 27 & 381 & 75 & 42 & 20.5 & 11.2 & 31.6 \\
\hline & $4 / 10-4 / 12$ & RM 9 & 383 & 107 & 30 & 28.2 & 7.9 & 36.1 \\
\hline
\end{tabular}


Appendix Table A-10. Releases of hatchery chinook salmon, coho salmon, and summer steelhead in the Umatilla River, November 1999 - May 2000.

\begin{tabular}{|c|c|c|c|c|c|c|c|}
\hline Species $^{a}$ & Age & $\begin{array}{c}\text { Hatchery } \\
\text { origin }\end{array}$ & $\begin{array}{l}\text { Release } \\
{\text { date }(\mathrm{s})^{b}}^{b}\end{array}$ & $\begin{array}{l}\text { Release } \\
\text { location }^{c}\end{array}$ & $\begin{array}{l}\text { River } \\
\text { mile }\end{array}$ & $\begin{array}{l}\text { Number } \\
\text { released }\end{array}$ & $\begin{array}{l}\text { Number } \\
\mathrm{CWT}^{d}\end{array}$ \\
\hline CHS & $1+$ & $\mathrm{LWSH}^{e}$ & $3 / 6-3 / 9$ & Imeques & 80.0 & 173,545 & 19,712 \\
\hline $\mathrm{CHS}$ & $1+$ & Umatilla & $3 / 6-3 / 9$ & Imeques & 80.0 & 357,722 & 152,867 \\
\hline $\mathrm{CHS}$ & $1+$ & Carson & $4 / 6-4 / 12$ & Imeques & 80.0 & 99,848 & 19,444 \\
\hline \multirow[t]{2}{*}{ CHS } & $1+$ & LWSH & $4 / 6-4 / 12$ & Imeques & 80.0 & 185,069 & 19,597 \\
\hline & & & & & Total & 816,184 & 211,620 \\
\hline $\mathrm{CHF}$ & $1+$ & $\begin{array}{c}\text { Bonnevill } \\
\mathrm{e}\end{array}$ & $3 / 6-3 / 9$ & Thornhollow & 73.5 & 235,246 & 26,956 \\
\hline \multirow[t]{2}{*}{$\mathrm{CHF}$} & $1+$ & Bonnevill & $4 / 6-4 / 13$ & Thornhollow & 73.5 & 234,510 & 28,223 \\
\hline & & & & & Total & $469,756^{f}$ & 55,179 \\
\hline $\mathrm{CHF}$ & $0+$ & Umatilla & $5 / 23$ & Thornhollow & 73.5 & 975,871 & 198,850 \\
\hline \multirow[t]{2}{*}{$\mathrm{CHF}$} & $0+$ & Umatilla & $5 / 24$ & Pendleton & 56.0 & $2,044,648$ & 395,493 \\
\hline & & & & & Total & $3,020,519^{f}$ & 594,343 \\
\hline $\mathrm{COH}$ & $1+$ & $\mathrm{LHCH}^{e}$ & $3 / 8-3 / 15$ & Pendleton & 56.0 & 513,288 & 26,422 \\
\hline $\mathrm{COH}$ & $1+$ & Cascade & $3 / 8-3 / 15$ & Pendleton & 56.0 & 249,792 & $51,736^{g}$ \\
\hline \multirow[t]{2}{*}{$\mathrm{COH}$} & $1+$ & Cascade & $4 / 21-4 / 28$ & Pendleton & 56.0 & 798,210 & 26,370 \\
\hline & & & & & Total & $1,561,290$ & 78,860 \\
\hline STS & $1+$ & Umatilla & $11 / 29^{\mathrm{h}}$ & Umatilla & 2.8 & 9,878 & 0 \\
\hline STS & $1+$ & Umatilla & $3 / 30-4 / 5$ & Minthorn & 64.5 & 51,659 & 20,980 \\
\hline STS & $1+$ & Umatilla & $4 / 3-4 / 12$ & Bonifer & $79.0^{i}$ & 49,343 & 21,552 \\
\hline \multirow[t]{2}{*}{ STS } & $1+$ & Umatilla & $4 / 24-4 / 28$ & Minthorn & 64.5 & 52,736 & 21,965 \\
\hline & & & & & Total & 163,738 & 64,497 \\
\hline
\end{tabular}

a $C H S=$ spring chinook salmon, $C H F=$ fall chinook salmon, $C O H=$ coho salmon, $S T S=$ summer steelhead.

$b$ Date range begins with start of volitional release and ends with forced release.

$c$ All release locations except Umatilla (RM 2.8) are sites of acclimation facilities.

${ }^{d} C W T=$ coded-wire tagged (and adipose-fin clipped); number is adjusted for tag loss and nonrecognizable fin clips.

e $L W S H=$ Little White Salmon Hatchery, $L H C H=$ Lower Herman Creek Hatchery.

${ }^{f}$ All CHF (1+ and 0+) not coded-wire tagged received a blank-wire tag.

$g$ Release consisted of 25,668 fish coded-wire tagged but not adipose-fin clipped.

$h$ Release of graded-out STS.

${ }^{i}$ River mile 2 of Meacham Creek at river mile 79.0 on the Umatilla River. 


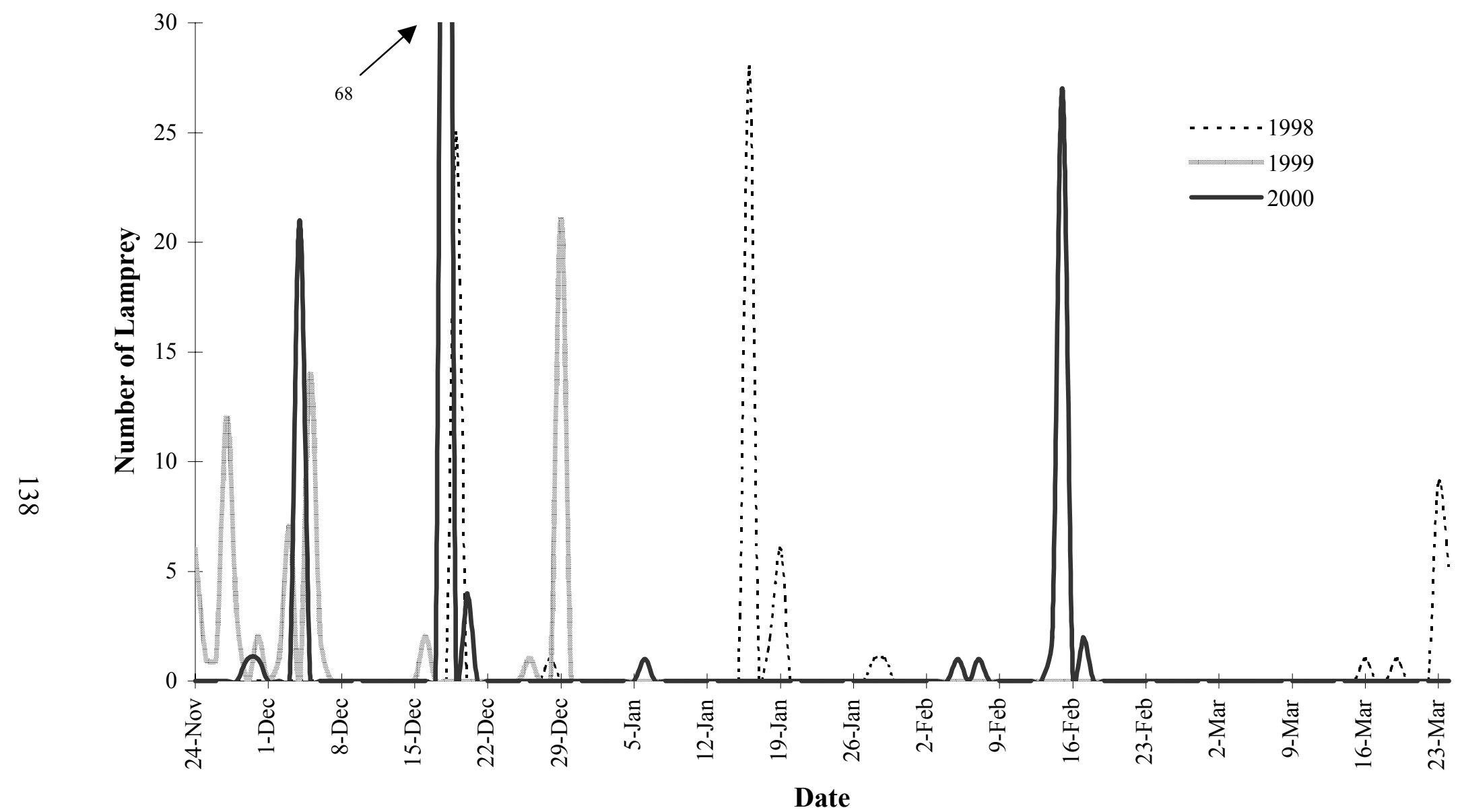

Appendix Figure A-1. Migration duration and frequency of juvenile Pacific lamprey (macrophthalmia), lower Umatilla River, November 1998 - March 2000. 


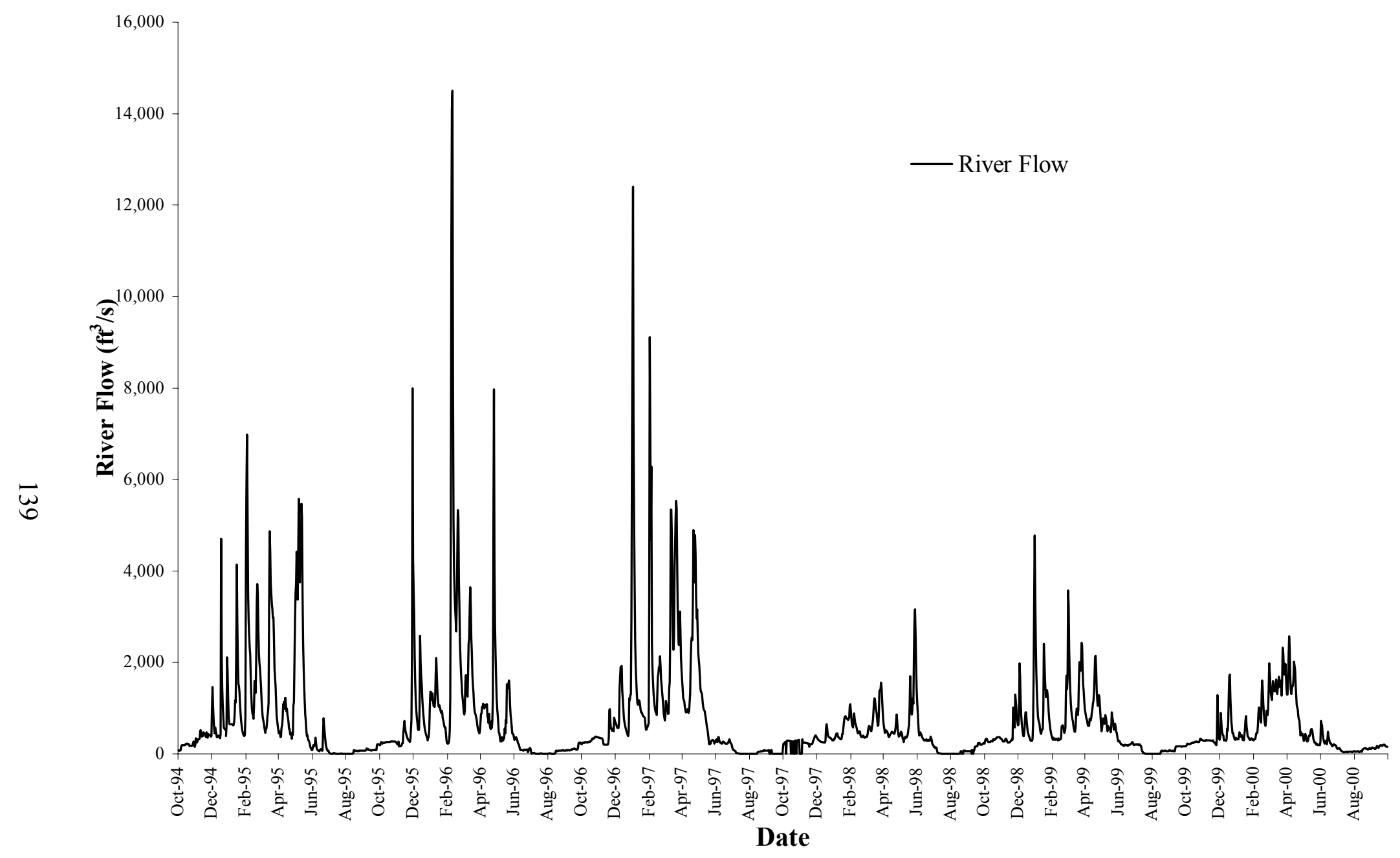

Appendix Figure A-2. River flow ( $\left.\mathrm{ft}^{3} / \mathrm{s}\right)$ measured at RM 2.1, lower Umatilla River, October 1994 - September 2000. 